\title{
NARDo Germano
}

(Arnaldo Valente Germano da Silva)

\section{Auto-Retrato Coletivo: \\ Poéticas de Abertura ao Espectador na [Des]Construção de uma Identidade Coletiva}

Dissertação apresentada ao Programa de Pós-Graduação em Artes, Área de Concentração Artes Plásticas, Linha de Pesquisa Poéticas Visuais, da Escola de Comunicações e Artes da Universidade de São Paulo, como exigência parcial para obtenção do Título de Mestre em Artes, sob a orientação da Profa. Dra. Monica Baptista Sampaio Tavares. 
Esta dissertação foi defendida em: de de perante a seguinte banca examinadora: 
Algumas pessoas importantes para este projeto:

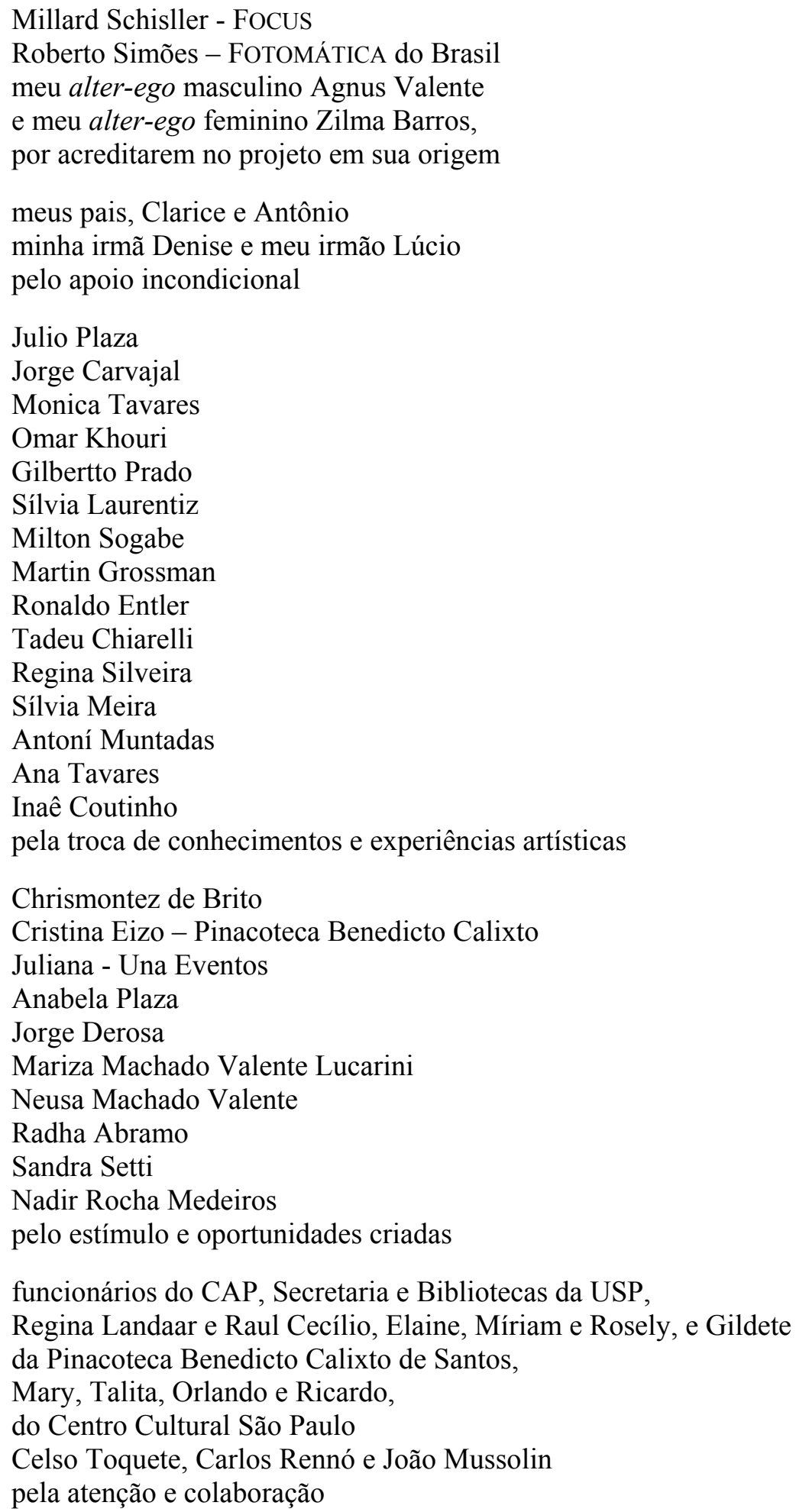

Dedico este trabalho a todos os participantes e interatores que fazem parte do Auto Retrato Coletivo 


\section{RESUMO}

O objeto desta dissertação de Mestrado é composto pela série Auto-Retrato Coletivo de Nardo Germano. Organizada artisticamente como repositório crítico de uma identidade coletiva - seu tema central -, a série constitui-se de auto-retratos híbridos entre o Indivíduo e o Coletivo, questionando a construção identitária marcada por estigmas sociais. As obras que compõem a série são: 1)Auto-Objeto; 2)Sujeitos; 3)Auto-Retrato por Metro Quadrado; 4)Cabeça Defronte; 5)Auto-Retr_Ato_Coletivo; 6)Especulares \#7; 7)Corpo Coletivo; 8)AlterEgo; 9)ANDROMAQUIA on-line; e 10)Doe Seu Rosto/Give Me Your Face.

A atual pesquisa artística dá continuidade a Auto-Objeto(1987), uma obra composta por painéis de auto-retratos sem negativo obtidos em cabine Fotomática, e articula-se a partir da digitalização de um conjunto imanente da obra Sujeitos(1987), colagens realizadas com auto-retratos acéfalos, recortes de textos, imagens e manchetes de jornal. Com o objetivo de, nesta fase, estabelecer novos contrapontos ao discurso monológico identitário oficial bem como ao conceito de uma autoridade do artista como autor que controla os sentidos da obra, a criação partiu da hipótese de que o investimento nos graus de abertura à recepção podem promover o dialogismo e polifonia almejados, com a inclusão da alteridade, das expressões e dos pontos de vista dos espectadores na noção de identidade coletiva veiculada nas obras, considerando os conceitos de "obra aberta" de Umberto Eco bem como de "dialogismo e polifonia" de Mikhail Bakhtin.

A presente dissertação discorre sobre aquelas obras originais - como paradigmas internos da criação - e sobre as obras produzidas durante esta pesquisa artística, focando nas proposições dialógicas de poéticas abertas, bem como nas estratégias de participação e interatividade então implementadas, realizadas em ambiente real e/ou através dos meios tecnológicos. O texto explicita e reflete sobre as poéticas de abertura envolvidas na recepção, comprovando por fim a hipótese de trabalho. Em suma, no que tange aos resultados sobre o tema proposto, conclui-se que Auto-Retrato Coletivo promove um movimento contínuo de construção e desconstrução identitária possibilitado pela abertura poética aos espectadores que, convertidos em participantes e/ou interatores, cumulativamente renovam, expandem e problematizam a identidade coletiva, inscrevendo-a na dimensão Utópica de Identidades Abertas.

\section{Palavras-Chave}

1. Auto-Retrato Coletivo

2. Obra Aberta

3. Dialogismo e Polifonia

4. Participação e Interatividade

5. Poética do Jogo e da Ação

6. Identidade e Alteridade

7. Corpo Coletivo

8. Fotografia e Mídias Digitais 


\begin{abstract}
The object of this dissertation of Master's degree is composed by Nardo Germano's series Collective Self-Portrait. Organized artistically as critical repository of a collective identity - its central theme -, the series is constituted of hybrid self-portraits between the Individual and the Collectivity, discussing the construction of identities characterized by social stigmata. The works that compose the series are: 1)Auto-Objeto; 2)Sujeitos; 3)AutoRetrato por Metro Quadrado; 4)Cabeça Defronte; 5)Auto-Retr_Ato_Coletivo; 6)Especulares \#7; 7)Corpo Coletivo; 8)AlterEgo; 9)ANDROMAQUIA on-line; e 10)Doe Seu Rosto/Give Me Your Face.

The current artistic research gives continuity the Auto-Objeto(1987), an art-work composed by panels of self-portraits without negative obtained at Photomaton Cabin, and organized through a process of scanning an immanent group of the art-work Sujeitos(1987), collages accomplished with acephalous self-portraits, cuttings of texts, images and newspaper headlines. With the objective of, in this phase, to establish new counterpoints to the monologic official speech about identity as well as to the concept of an authority of the artist as author that controls the meanings of the art-work, the creation worked with the hypothesis that the investment in the opening degrees to the reception can promote the necessary dialogism and polyphony, with the inclusion of the spectators' alterity, expressions and points of view in the notion of collective identity in the art-works, considering the concepts of Umberto Eco's “open work" and Mikhail Bakhtin's “dialogism and polyphony”.

The present dissertation describes those original art-works - as internal paradigms of the creation - and the art-works produced during this artistic research, focusing in the dialogical propositions of open poetics, as well as in the strategies of participation and interactivity implemented, in real ambience and/or through the technological media. The text explicits and reflects the poetics of opening to the spectator involved in the reception, proving finally the work hypothesis. In short, with respect to the results on the proposed theme, the conclusion is that Collective Self-Portrait promotes a continuous movement of construction and deconstruction of identities, possible by the poetical openness to the spectators who, converted in participants and/or interactors, cumulatively renew, expand and problematize the collective identity, enrolling it in the Utopian dimension of Open Identities.
\end{abstract}

\title{
KEY-WORDS
}

1. Collective Self-Portrait

2. Open Work

3. Dialogism and Polyphony

4. Participation and Interactivity

5. Play and Action Poetics

6. Identity and Alterity

7. Collective Body

8. Photograph and Digital Media 


\author{
SUMÁRIO \\ Auto-Retrato Coletivo: \\ Pó́ticas de Abertura ao Espectador \\ NA [DES]CONSTRUÇÃo DE UMA IDENTIDADE COLETIVA
}

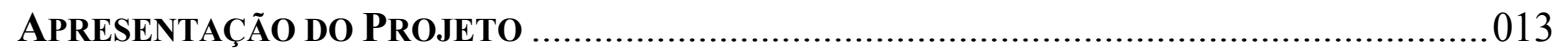

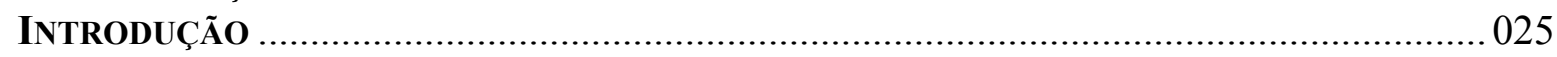

Capítulo 1 - Auto-Retrato Híbrido Entre o Indivíduo e o Coletivo ............. 029

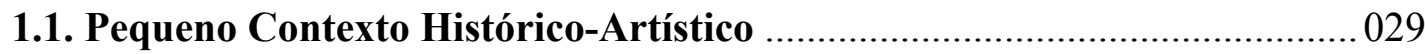

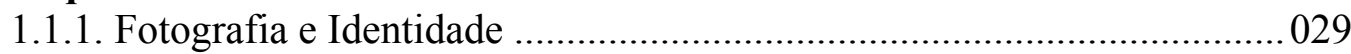

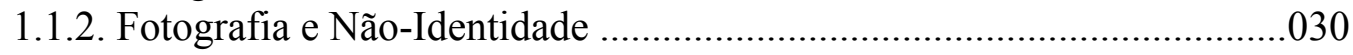

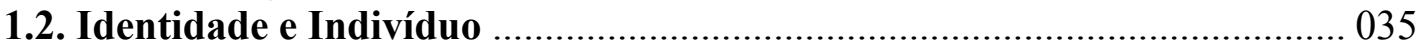

1.2.1. Auto-Retrato em Natureza Morta ..........................................................035

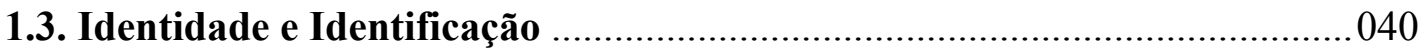

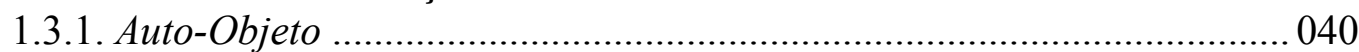

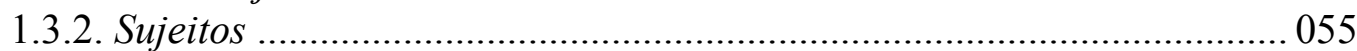

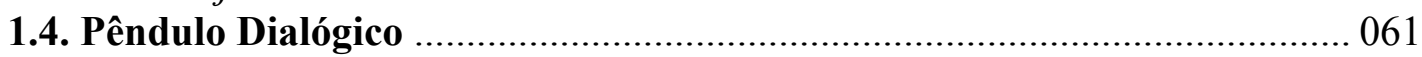

1.4.1. Poética Predominante em Auto-Objeto .................................................. 062

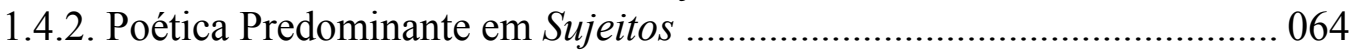

1.4.3. Encaminhamento para Novas Aberturas Dialógicas .............................. 066

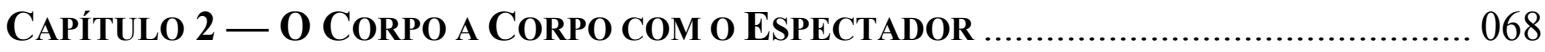

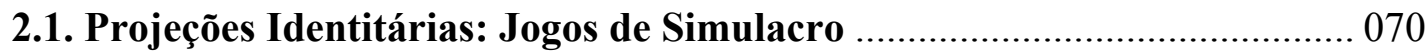

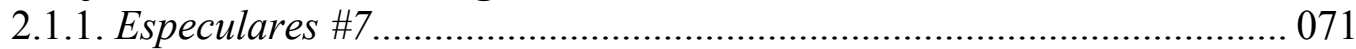

2.1.2. Auto-Retrato por Metro Quadrado \#1 .................................................. 076

2.2. Auto-Retr_Ato Coletivo: Inversão do Discurso Ideológico ...........................083

2.3. Cabeça Defronte: Um Ambiente Identitário ..............................................090

2.4. Corpo Coletivo: Performances Participativas ............................................. 103

Capítulo 3 - Auto-Retrato Coletivo On-Line: Presenças Distantes ............ 120

3.1. AlterEgo: o Dialético e o Dialógico .......................................................... 124

3.1.1. $1^{\mathrm{o}}$ Nível: Anti-Efeito de Liberdade .................................................. 131

3.1.2. $2^{\circ}$ Nível: Corpo Coletivo Virtual - Entre o Icônico e o Indicial.................. 135

3.2. ANDROMAQUIA On-Line: Identidades Políticas ................................... 140

3.2.1. $1^{\mathrm{o}}$ Momento: Exercício Dialógico no Contexto do Outro .......................146

3.2.2. $2^{\circ}$ Momento:Identidade em Poiesis: o significado enquanto problema......149

3.2.3. $3^{\circ}$ Momento: Instantaneidade e Inclusão ............................................... 153

3.3. Doe seu Rosto/Give me your Face: Identidades Metonímicas ..................... 157

3.3.1. Entre o Presencial e a Telepresença ..................................................... 162

3.3.2. Auto-Retrato e Auto-Referência ............................................................ 164

CONCLUSÃO: IdENTIDAdes UtóPICAS / IdENTIDAdES AbERTAS …............................ 170

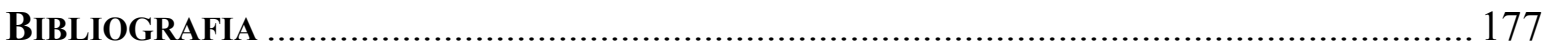

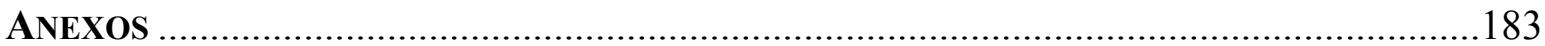




\section{LISTA DE FIGURAS}

FIG.

NSC-01 — Nus Sem Cabeça, 1981/85. Nardo Germano.

NSC-02 - Nus Sem Cabeça, 1981/85. Nardo Germano..

NSC-03 - Nus Sem Cabeça, 1981/85. Nardo Germano..

NSC-04 - Nus Sem Cabeça, 1981/85. Nardo Germano..

NSC-05 - Nus Sem Cabeça, 1981/85. Nardo Germano...

NSC-06 — Nus Sem Cabeça, 1981/85. Nardo Germano...

NSC-07 — Nus Sem Cabeça, 1981/85. Nardo Germano..

NSC-08 - Nus Sem Cabeça, 1981/85. Nardo Germano...

NSC-09 - Nus Sem Cabeça, 1981/85. Nardo Germano..

PTF-01 — Projeção para Tungstênio e Fluorescentes, 1986. Nardo Germano.

PTF-02 — Projeção para Tungstênio e Fluorescentes, 1986. Nardo Germano...................................... 033

PTF-03 — Projeção para Tungstênio e Fluorescentes, 1986. Nardo Germano........................................ 033

PTF-04 _ Projeção para Tungstênio e Fluorescentes, 1986. Nardo Germano........................................ 033

PTF-05 — Projeção para Tungstênio e Fluorescentes, 1986. Nardo Germano....................................... 033

PTF-06 — Projeção para Tungstênio e Fluorescentes, 1986. Nardo Germano...................................... 033

ARNM-01 — Auto-Retrato em Natureza Morta I, 1985. Nardo Germano ........................................... 036

ARNM-02 — Auto-Retrato em Natureza Morta III, 1985. Nardo Germano ………............................. 037

ARNM-03 - Auto-Retrato em Natureza Morta V, 1985. Nardo Germano ........................................... 038

ATR-01 — Auto-Objeto, 1987, painel \# 1. Nardo Germano .................................................................. 041

ATR-02 — Auto-Objeto, 1987, painel \# 2 (detalhe). Nardo Germano ................................................... 042

ATR-03 — Auto-Objeto, 1987, painel \# 5 (detalhe). Nardo Germano …………………….................... 043

ATR-04 — Auto-Objeto, 1987, painel \# 6 (detalhe). Nardo Germano ..................................................... 044

ATR-05 - Auto-Objeto, 1987, painel \# 5 (detalhe 2). Nardo Germano ................................................ 045

ATR-06 — Auto-Objeto, 1987, painel \# 6 (detalhe 2). Nardo Germano ............................................... 045

SJT-01 — Sujeitos, 1987. Nardo Germano ………………………………………………………..... 056

SJT-02 — Sujeitos, 1987. Nardo Germano ………………......................................................... 056

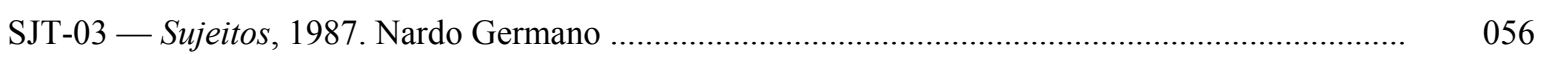

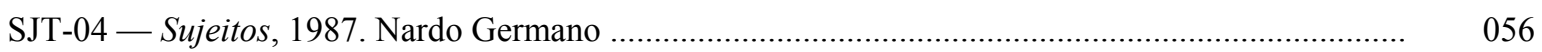

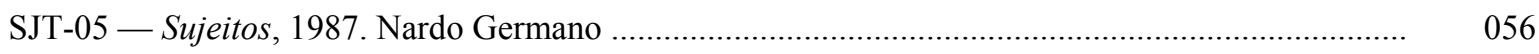

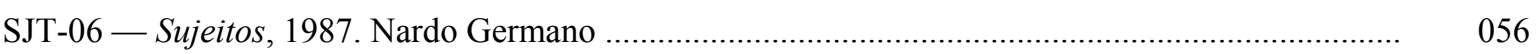

SJT-07 — Sujeitos, 1987. Nardo Germano …………………………………………………........ 056

SJT-08 — Sujeitos, 1987. Nardo Germano ………………………………………………...... 056

SJT-09 — Sujeitos, 1987. Nardo Germano ………………………………………………………....... 056

ESP-01 — Especulares \# 7, 2004. Nardo Germano ....................................................................... 071

ESP-02 — Especulares \# 7, 2004. Nardo Germano ........................................................................ 071

ESP-03 - Especulares \# 7, 2004. Nardo Germano .......................................................................... 072 
FIG.

ESP-04 - Especulares \# 7, 2004. Nardo Germano

ARMQ-01 - Auto-Retrato por Metro Quadrado, 2002. Nardo Germano

ATR-01 - Auto-Retr_Ato_Coletivo, 2003/2004. Nardo Germano

CBD-01 — Instalação Participativa Cabeça-Defronte, 2003. Nardo Germano ...................................... 091

CBD-02 — Instalação Participativa Cabeça-Defronte, 2003. Nardo Germano ………………................ 092

CBD-03 — Instalação Participativa Cabeça-Defronte, 2003. Nardo Germano ..................................... 093

CBD-04 — Instalação Participativa Cabeça-Defronte, 2003. Nardo Germano ...................................... 093

CBD-05 - Instalação Participativa Cabeça-Defronte, 2003 (detalhe: espelho). Nardo Germano ......... 094

CBD-06 - Instalação Participativa Cabeça-Defronte, 2003 (detalhe: espelho). Nardo Germano ......... 095

CBD-07 — Instalação Participativa Cabeça-Defronte, 2003 (detalhe). Nardo Germano ....................... 096

CBD-08 — Instalação Participativa Cabeça-Defronte, 2003 (detalhe). Nardo Germano ....................... 097

CBD-09 — Instalação Participativa Cabeça-Defronte, 2003 (detalhe). Nardo Germano ....................... 098

CRP-01 - Performance Participativa Corpo Coletivo, 2006. Nardo Germano .................................... 104

CRP-02 - Performance Participativa Corpo Coletivo, 2006. Nardo Germano ...................................... 104

CRP-03 - Performance Participativa Corpo Coletivo, 2006. Nardo Germano ....................................... 105

CRP-04 - Performance Participativa Corpo Coletivo, 2006. Nardo Germano ...................................... 105

CRP-05 - Performance Participativa Corpo Coletivo, 2006. Nardo Germano ....................................... 106

CRP-06 — Performance Participativa Corpo Coletivo, 2006. Nardo Germano ...................................... 106

CRP-07 — Performance Participativa Corpo Coletivo, 2006. Nardo Germano .................................... 106

CRP-08 - Performance Participativa Corpo Coletivo, 2006. Nardo Germano ...................................... 107

CRP-09 - Performance Participativa Corpo Coletivo, 2006. Nardo Germano ...................................... 107

CRP-10 — Performance Participativa Corpo Coletivo, 2006. Nardo Germano .................................... 108

CRP-11 - Performance Participativa Corpo Coletivo, 2006. Nardo Germano ...................................... 108

CRP-12 - Performance Participativa Corpo Coletivo, 2006. Nardo Germano ..................................... 109

CRP-13 - Performance Participativa Corpo Coletivo, 2006. Nardo Germano .................................... 109

CRP-14 - Performance Participativa Corpo Coletivo, 2006. Nardo Germano ..................................... 109

CRP-15 - Performance Participativa Corpo Coletivo, 2006. Nardo Germano .................................... 109

ALT-01 - AlterEgo, 2003/2005. Nardo Germano .......................................................................... 125

ALT-02 — AlterEgo, 2003/2005. Nardo Germano ………………………………….................. 125

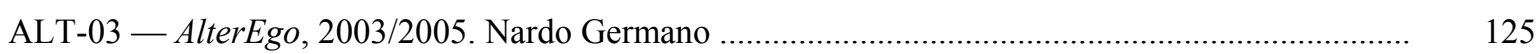

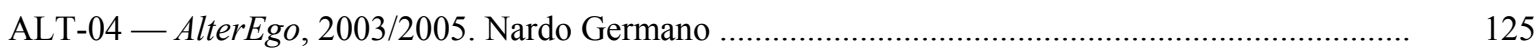

ALT-05 - AlterEgo, 2003/2005. Nardo Germano …………………………………………......... 125

ALT-06 - AlterEgo, 2003/2005. Nardo Germano …………………………………………………. 125

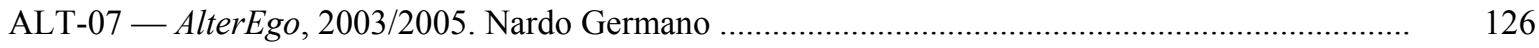

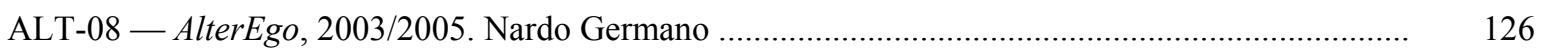

ALT-09 — AlterEgo, 2003/2005. Nardo Germano ............................................................................ 126

ALT-10 — AlterEgo, 2003/2005. Nardo Germano …………...................................................... 126

ALT-11 — AlterEgo, 2003/2005. Nardo Germano …….................................................................. 126

ALT-12 — AlterEgo, 2003/2005. Nardo Germano ……….................................................................... 126 
FIG.

ALT-13 - AlterEgo, 2003/2005. Nardo Germano

ALT-14 - AlterEgo, 2003/2005. Nardo Germano

ALT-15 - AlterEgo, 2003/2005. Nardo Germano

ALT-16 - AlterEgo, 2003/2005. Nardo Germano

ALT-17 - AlterEgo, 2003/2005. Nardo Germano

ALT-18 - AlterEgo, 2003/2005. Nardo Germano

ALT-19 - AlterEgo, 2003/2005. Nardo Germano

ALT-20 - AlterEgo, 2003/2005. Nardo Germano

ALT-21 - AlterEgo, 2003/2005. Nardo Germano

ANDR-01 — ANDROMAQUIA on-line, 2004/2006. Nardo Germano ..

ANDR-02 — ANDROMAQUIA on-line, 2004/2006. Nardo Germano ................................................ 142

ANDR-03 — ANDROMAQUIA on-line, 2004/2006. Nardo Germano ............................................... 143

ANDR-04 — ANDROMAQUIA on-line, 2004/2006. Nardo Germano ................................................. 144

ANDR-05 — ANDROMAQUIA on-line, 2004/2006. Nardo Germano ……………………………..... 144

ANDR-06 — ANDROMAQUIA on-line, 2004/2006. Nardo Germano ……………………………....... 144

ANDR-07 — ANDROMAQUIA on-line, 2004/2006. Nardo Germano ............................................... 144

ANDR-08 — ANDROMAQUIA on-line, 2004/2006. Nardo Germano ................................................. 144

ANDR-09 - ANDROMAQUIA on-line, 2004/2006. Nardo Germano ............................................... 144

ANDR-10 - ANDROMAQUIA on-line, 2004/2006. Nardo Germano .................................................. 144

ANDR-11 — ANDROMAQUIA on-line, 2004/2006. Nardo Germano ................................................ 144

ANDR-12 - ANDROMAQUIA on-line, 2004/2006. Nardo Germano ................................................ 144

PPDSR-01 — Doe Seu Rosto/Give Me Your Face, 2001/2006. Nardo Germano ................................... 158

PPDSR-02 — Doe Seu Rosto/Give Me Your Face, 2001/2006. Nardo Germano .................................. 158

PPDSR-03 — Doe Seu Rosto/Give Me Your Face, 2001/2006. Nardo Germano .................................. 158

PPDSR-04 — Doe Seu Rosto/Give Me Your Face, 2001/2006. Nardo Germano ................................... 158

PPDSR-05 — Doe Seu Rosto/Give Me Your Face, 2001/2006. Nardo Germano ................................. 158

PPDSR-06 — Doe Seu Rosto/Give Me Your Face, 2001/2006. Nardo Germano ................................... 158

DSR-01 — Doe Seu Rosto/Give Me Your Face, 2001/2006. Nardo Germano ........................................ 159

DSR-02 — Doe Seu Rosto/Give Me Your Face, 2001/2006. Nardo Germano ....................................... 160

DSR-03 — Doe Seu Rosto/Give Me Your Face, 2001/2006. Nardo Germano ........................................ 161 
OBRAS ANTECEDENTES, PARADIGMAS INTERNOS DE CRIAÇÃO E

CORpus da SÉRIE $\boldsymbol{A}$ UTO-RETRATO COLETIVO, DE NARDO GERMANO

- Doe seu Rosto/Give me Your Face, 2001/2006

obra participativa e interativa.

No site www.nardogermano.com/autoretratocoletivo/doeseurosto

Pinacoteca Benedicto Calixto 2006

- Performance Participativa Corpo Coletivo, 2006

obra participativa

Pinacoteca Benedicto Calixto 2006

Maratona Cultural - Caros Amigos de Santos 2006

Centro Histórico de Santos: Valongo, Boulevard da Praça XV de Novembro e Praça Mauá (Paço Municipal)

Virada Cultural São Paulo 2006

Centro Histórico de Sao Paulo: Mercado Municipal, Largo São Bento, Praça do Patriarca, Praça da Sé e Centro Cultural São Paulo-CCSP

- ANDROMAQUIA On-Line, 2004/2006

obra virtual na exposição $C Y B E R-A R T E$. Virada Cultural São Paulo 2006

ao lado de obras Agnus Valente, Carmela Gross, Julio Plaza e Regina Silveira.

No site www.nardogermano.com/autoretratocoletivo/andromaquiaonline

- AlterEgo, 2003/2005

FILE - Festival de Linguagem Eletrônica. 2006

(No projeto ÚTERO portanto COSMOS) www.file.org.br

Exposição virtual Útero portanto Cosmos II. 2005

No site www.agnusvalente.com/uteroportantocosmos expondo ao lado de Agnus Valente, Augusto de Campos, Carmela Gross, Décio Pignatari, Haroldo de Campos, Julio Plaza, Regina Silveira e Ronaldo Azeredo.

Na web desde 19.abril/2005.

Obra interativa: Colagem digital de Fotografia Fotomática + papel jornal digitalizados e manipulados digitalmente, com inserção de texto ("ego" "alter"), submetidos a múltiplos efeitos: solarização, negativo, granulação e pixelate, com modelos de comportamento interativo on-line.

No site www.nardogermano.com/autoretratocoletivo/alter_ego

- Especulares \# 7, 2004

Mostra do Grupo de Estudos de Fotografia da MariAntônia.

CEUMA MariAntônia - Coord: Inaê Coutinho, expondo ao lado de Elaine Rabinovich, Juliana Laurino, Marli Tassinari, Sandra Luz e Sofia Mattos.

São Paulo, SP, 9.dez/2004 a 30.jan/2005.

Obra participativa (especular): colagem de fotos Fotomática original sem negativos, jornal e espelho. $30 \mathrm{~cm}$ x $40 \mathrm{~cm}$ 
- Auto-Retr_Ato_Coletivo, 2003/2004

Exposição Uma Viagem de 450 Anos

SESC SÃO PAULO - Pompéia. Curadoria: Radha Abramo. Como artista convidado, ao lado de José Roberto Aguilar, Maria Bonomi, Amélia Toledo, Antônio Peticov, Iatã Canabrava, Cléber Machado, Percival Tirapelli, Rubens Gerchman, Cláudio Tozzi, Cássio Vasconcelos, Fernando Durão, Caciporé Torres, Hudinilson Jr., Lúcia Py, Gregório Gruber, Domício Machado e outros.

Textos críticos de: Jacob Klintowitz, Paulo Klein, Lisbeth Rebollo Gonçalves, Mario García-Guillén, Dalva de Abrantes, Enock Sacramento, Antônio Santoro Junior, Carlos Soulié do Amaral, Ivo Zanini, Elvira Vernaschi, José Henrique Fabre Rolim, Luiz Ernesto Kawall, Mariza Bertoli e outros.S. Paulo, jan-abr/2004. Hotsite [http://www.sescsp.org.br/sesc/hotsites/viagem450anos/]

Itinerância da exposição Uma Viagem de 450 Anos.

Espaço Cultural CONJUNTO NACIONAL PAULISTA - Curadoria: Dario Bueno. Criação: Radha Abramo/SESC-Pompéia. Artista convidado, expondo ao lado de José Roberto Aguilar, Antônio Peticov, Cláudio Tozzi, Domício Machado, Francisco Panachão, Marta Strambi, Percival Tirapelli, Rubens Gerchman, Thomas Farkas e outros).

São Paulo, SP, 13.setembro a 16.outubro/2004.

Obra participativa (manipulável): Transferência térmica de 25 fotografias de Fotomática digitalizadas e ampliadas, impressas sobre uma capa de mala e sobre 25 camisetas brancas acondicionadas em uma mala de viagem (aberta).

$80 \times 162 \times 42 \mathrm{~cm}$

- Cabeça-Defronte, 2003

Exposição Arte do Novo Século

Centro Exposições GUIMARÃES ROSA - Curadoria: Sandra Setti e Sílvia Meira (USP), expondo ao lado de Antônio Peticov, Caciporé Torres, Cláudio Tozzi, Cléber Machado, Eide Feldon, Hugo Fortes, Paulo Cheida Sans, Rubens Gerchman, Sissi Fonseca e outros.

Jundiaí, SP, novembro.dezembro/2003.

Texto crítico: "A Estética Contemporânea”, de Sílvia Meira.

Instalação Participativa (inscrições): Fotografias digitalizadas, ampliadas em papel auto-adesivo, aplicadas sobre parede; espelhos de mão e pincéis atômicos.

$6 \mathrm{~m} \times 6 \mathrm{~m} \times 4 \mathrm{~m}$

- Auto-Retrato por Metro Quadrado \# 1, 2002

Exposição Matérias no Tempo/Tempos na Matéria.

Galeria ACBEU - Associação Cultural Brasil-Estados Unidos.

[www.acbeubahia.org.br/hpp/cultural/gvirtual/materias/materias.htm ]

Salvador, BA, agosto.setembro/2003.

Instalação Participativa (especular): Imagens fotográficas digitalizadas, ampliadas e impressas em papel auto-adesivo; laminadas e aplicadas sobre parede.

Acervo: ACBEU, Salvador, Bahia, 2003.

$1 \mathrm{~m} \times 1 \mathrm{~m}$ 
- Sujeitos, 1987

Recy-Clic

Galeria FOCUS.

São Paulo, SP, 1987.

Colagem de fotos Fotomática sem negativos e recortes de jornal

1 painel de $100 \times 70 \mathrm{~cm}$

- Auto-Objeto, 1987

Mês Internacional da Fotografia.

Oficina Cultural Oswald de Andrade - Mostra Fotografia FOCUS.

São Paulo, SP, outubro.1990.

Recy-Clic

Galeria FOCUS.

São Paulo, SP, 1987.

Acervo: FOCUS, São Paulo, SP, 1987

835 fotos para identidade, obtidas em cabine Fotomática, sem negativos.

7 painéis de $100 \times 70 \mathrm{~cm}$

- Projeção para Tungstênio e Fluorescentes, 1986

Acervo: FOCUS. PRÊMIO AQUISIÇÃo. 1. ${ }^{\circ}$ lugar. São Paulo, SP, 1986.

Auto-Retrato in absentia em cromos coloridos.

- Auto-Retrato em Natureza Morta, 1985

Centro Cultural São Paulo - Mostra de Fotografia FOCUS.

São Paulo, SP. 1988.

Individual na Galeria FOCUS.

São Paulo, 1986.

Acervo: FOCUS. PRÊMIO AQUISIÇÃo.

1. ' lugar. São Paulo, SP, 1985.

Auto-Retrato em P\&B: ensaio com 5 fotografias em $18 \times 24 \mathrm{~cm}$

montadas em pranchas pretas de $30 \times 30 \mathrm{~cm}$.

- Nus sem Cabeça, 1981-1985

Auto-Retratos Acéfalos. P\&B 


\author{
ApresentaÇão do Projeto \\ Título: \\ AUTO-RETRATO COLETIVO: \\ Pó́ticas de Abertura ao Espectador \\ NA [DES]CONSTRUÇÃo de UMA IdENTIDAdE COLETIVA
}

\title{
RESUMO
}

A presente pesquisa de Mestrado apresenta duas vertentes: pesquisa criativa e científica. De um lado, propõe a produção de um corpus artístico a ser integrado à série de ensaios fotográficos Auto-Retrato Coletivo; de outro, uma dissertação cuja linha mestra de reflexão será a identidade coletiva na relação com as poéticas abertas ao espectador, suas modalidades de dialogismo e polifonia, tal como se configura nos ensaios fotográficos em questão.

\section{DELIMITAÇÃo do ESTUdO}

\section{TEMA}

A Identidade Coletiva na relação dialógica com o espectador.

\section{ОвJеTO}

Os ensaios fotográficos da série Auto-Retrato Coletivo.

Auto-Retrato Coletivo compõe-se de um conjunto de auto-retratos originais, sem negativo, obtidos em cabine Fotomática e de colagens desses auto-retratos com recortes de jornal que, discutindo a questão da construção da identidade social, expandiu-se para a constituição de auto-retratos híbridos entre o Indivíduo e o Coletivo, finalmente organizando-se artisticamente como repositório crítico de uma identidade coletiva.

\section{Problema}

A série Auto-Retrato Coletivo instaurou-se a partir da apropriação de fotos Fotomática que 
compuseram o ensaio Auto-Objeto, no qual a constituição da noção de identidade coletiva se efetiva pela quantidade e repetição dos auto-retratos. Subseqüentemente, com a colagem de manchetes, textos e fotos de jornal nos auto-retratos do ensaio Sujeitos, essa noção se amplia, com uma abertura dialógica ${ }^{1}$ viabilizada pela apropriação do repertório e do discurso dessa mídia, especificamente os jornais populares no tratamento dos fait-divers. Esses dois ensaios iniciais da série Auto-Retrato Coletivo embasam-se no ponto de vista do autor sempre presente na articulação da intertextualidade mobilizada pela obra. No embate criativo com a obra, revelou-se a necessidade de redimensionar esse dialogismo até então alcançado, no sentido de instaurar uma polifonia, aquela "pluralité de voix e des consciences indépendantes et distinctes"2 de que nos fala Bakhtin. Assim, seria possível obter uma "complexité du modèle artistique du monde" ${ }^{, 3}$ numa obra que se propõe como identidade coletiva.

$\mathrm{Na}$ série como um todo, a constituição do coletivo já vinha se encaminhando para uma perspectiva dialógica e polifônica, com a inserção de outros repertórios por meio da apropriação do discurso jornalístico e com outras pessoas posando para o auto-retrato. Nesse sentido, o problema que se formula é: Como promover novas experimentações dialógicas e polifônicas nos ensaios fotográficos da série Auto-Retrato Coletivo?

\section{HIPÓTESE}

Nesta pesquisa, partiremos da hipótese de que o dialogismo e a polifonia de uma obra de arte estão associados aos graus de abertura ao espectador. Assim, consideramos que a proposição de novos graus de abertura corresponde à criação de novas possibilidades de dialogismo e polifonia, fator que, no contexto desta pesquisa, repercutirá na noção de identidade coletiva veiculada na obra.

A forma de recepção que os ensaios de Auto-Retrato Coletivo estabelecem com o espectador efetiva-se numa abertura de $1^{\circ}$ grau, enquanto poéticas da obra aberta. A problematização do coletivo, que permeava o processo criativo, solicitava, portanto, um grau maior de abertura em relação ao espectador. Assim, construir estratégias participativas e interativas junto ao público em ambiente real e/ou através dos meios eletrônicos revela-se imperativo para

\footnotetext{
${ }^{1}$ Bakhtin, Mikhail. La Poétique de Dostoievski, édition du Seuil, 1970, p.347

${ }^{2}$ BAkHtin, Mikhail. La Poétique de Dostoievski, édition du Seuil, 1970, p.32 - tradução: "pluralidade de vozes e de consciências independentes e distintas" (t.a.)

${ }^{3}$ BAKhtin, Mikhail. La Poétique de Dostoievski, édition du Seuil, 1970, p.347 - tradução: “complexidade do modelo artístico do mundo" (t.a.)
} 
alcançar uma identidade coletiva que, a partir de então, não seja mais fruto exclusivo de minhas próprias reflexões ou, como sublinha Couchot, de minha "autoridade" de $\operatorname{artista}^{4}$, mas que se amplie com a inserção de cada espectador que, no exercício operativo de sua formatividade, como proposto por Pareyson, enquanto pessoa "irrepetível em sua singularidade e no entanto infinitamente aberta a possibilidades que ela mesma vai descobrir" ${ }^{, 5}$, venha a contribuir com a alteridade, o dialogismo e a polifonia necessários para a constituição mais abrangente possível de um auto-retrato coletivo. Assim, variar os graus de abertura da obra para participação e interação $\left(2^{0}\right.$ e $3^{\circ}$ graus de abertura, cf. Eco ${ }^{6}$ e Plaza $\left.{ }^{7}\right)$, sem perder de vista um investimento poético/estético inerente ao objeto artístico em formação, parece ser um procedimento adequado para trazer esse coro de vozes, essa intertextualidade necessária ao meu projeto artístico.

\section{OBJETIVOS}

O presente projeto, por suas características, apresenta-se ao Programa de Pós-Graduação da ECA/USP na linha de pesquisa de Poéticas Visuais. Ao conjugar prática e teoria, promoveremos um movimento pendular constante entre a pesquisa científica, que resultará na dissertação final, e a pesquisa criativa, cujos trabalhos artísticos produzidos serão incorporados à série Auto-Retrato Coletivo como resultado artístico da pesquisa.

Assim, cumpre considerar os objetivos, tanto geral quanto específicos, segundo seus aspectos artístico e científico.

O projeto tem como objetivo artístico geral expandir a noção de identidade coletiva nos ensaios fotográficos da série Auto-Retrato Coletivo. Como objetivo científico geral, buscaremos analisar criticamente e refletir sobre a identidade coletiva na relação com as poéticas abertas ao espectador e com os tipos de dialogismo, polifonia e intertextualidade, investigando suas relações mútuas, buscando compreender o seu conceito e as implicações artísticas trazidas para a obra.

\footnotetext{
${ }^{4}$ Couchot, Edmond. "O tempo real nos dispositivos artísticos” in Leão, Lucia. Interlab : Labirintos do Pensamento Contemporâneo, São Paulo, Iluminuras, 2002, p. 101.

${ }^{5}$ PAreyson, Luigi. Estética - Teoria da Formatividade. Rio de Janeiro, Petrópolis, ed. Vozes, 1993, p.176.

${ }^{6}$ ECO, Umberto. Obra Aberta, Coleção Debates, São Paulo, Editora Perspectiva. 1988 (trad. Giovanni Cutolo).

${ }^{7}$ PLAZA, Julio. Arte e Interatividade: autor-obra-recepção, 2000, p.10 Acessado em 25/06/2003 [http://www.plural.com.br/jplaza/texto01.htm].
} 
Tendo em vista o alcance do objetivo geral em seus dois aspectos, cumpre ressaltar que os objetivos específicos são igualmente de ordem empírica e teórica, a saber:

1. pesquisar e experimentar estratégias participativas e interativas para os novos ensaios da série, de modo a promover a inserção do espectador na obra;

2. Buscar subsídios na literatura estudada de modo a situar Auto-retrato Coletivo no seu contexto histórico e artístico e, com essa compreensão, prosseguir o desenvolvimento criativo das obras em sintonia com sua proposta essencial, dando prosseguimento coerente ao seu trajeto;

3. Do estudo das Etapas do Processo Criativo e dos Métodos Heurísticos de criação das obras que pertencem ao paradigma interno da criação que se vai empreender nesta pesquisa (obras Auto-Retrato em Natureza Morta, Auto-Objeto e Sujeitos), buscar a compreensão do modo de formação de Auto-Retrato Coletivo de modo a não perder de vista uma unidade de estrutura para a série com a inclusão das novas obras em seu corpus;

4. tratar dos aspectos práticos e teóricos referentes à recepção para a formulação de novas estratégias para as obras no contexto das poéticas de abertura ao receptor;

5. Exposição dos novos ensaios da série Auto-Retrato Coletivo, em sua totalidade ou em módulos independentes, para que a contribuição dos espectadores traga subsídios para nossa análise de modo a elucidar aspectos de dialogismo e polifonia nas reflexões sobre identidade coletiva.

Vale reiterar o espírito constante de contribuição e feed-back mútuos entre teoria e prática, destacando as reflexões que me mobilizam na feitura dos novos ensaios fotográficos da série Auto-Retrato Coletivo no sentido de compreender sua inserção no âmbito das poéticas participativas e interativas, bem como o encaminhamento para novas aberturas dialógicas da identidade coletiva na obra.

\section{Metodologia}

Como mencionado anteriormente, este projeto se insere na linha de pesquisa de Poéticas Visuais e a investigação que ora se efetua promove constantes realimentações do fenômeno artístico para a teoria, num procedimento indutivo, como também da teoria para o fenômeno artístico, num procedimento dedutivo. Assim, a metodologia empregada transita entre as investigações exploratórias, descritivas e explicativas quanto aos fins e, quanto aos meios, 
transita entre as pesquisas bibliográfica, de laboratório, documental e experimental.

- Pesquisa Exploratória: esse tipo de investigação é fundamental para a pesquisa empreendida e, presente em todo o processo, seja criativo ou intelectual, contribui com sua característica de sondagem. Nesse sentido, o espírito investigador do artista/pesquisador se coloca aberto às possíveis descobertas, explorando os objetivos propostos e procedendo gradualmente a um levantamento da situação. Trata-se de um procedimento metodológico favorável às pesquisas que abordam temas contemporâneos, como neste caso a questão da interatividade. De planejamento flexível, a pesquisa exploratória possibilita a consideração dos problemas em diversos aspectos, redimensionando e/ou complementando sua discussão e, assim, contribuindo para o aprimoramento das idéias.

- Pesquisa Descritiva: esta pesquisa promove uma descrição dos procedimentos poéticos empregados e dos fenômenos decorrentes a partir das exposições das obras participativas ou interativas, explicitando características de cada fenômeno. A partir da identificação dos elementos trazidos para a obra, investir-se-á numa descrição da natureza e da relação entre os fenômenos verificados.

- Pesquisa Explicativa: prevê uma abordagem dos fatores que contribuem para a ocorrência de determinado fenômeno para reconhecer a diferenciação dialógica de cada obra produzida, em quê consiste esse dialogismo e suas implicações para a interpretabilidade de Auto-Retrato Coletivo, a partir dos dados trazidos pela pesquisa descritiva. Perseguindo o objetivo principal, tanto artístico quanto científico, buscará elucidar a natureza e as especificidades do novo corpus constituído pelos ensaios fotográficos em questão.

- Pesquisa Bibliográfica: para além do material convencional, como livros, revistas e teses, a pesquisa bibliográfica expande-se para outros suportes, como $c d$-roms, e avança para o dinamismo da busca de dados disponíveis na Internet. Tanto no convencional como nas redes eletrônicas, a pesquisa bibliográfica empreende-se de duas formas: uma sistemática, através da seleção de uma bibliografia fundamental que dá sustentação ao conjunto bem como de seu enriquecimento ao agregar as bibliografias afins citadas nos cursos ministrados no Programa de Pós-Graduação; e outra exploratória, em que uma 
referência leva a outra, criando uma rede de interconexões de bibliotecas (convencional) e sites (internet), compondo um material rico em diversidade e submetido a uma atenta triagem e avaliação crítica prévia. Esta pesquisa se ocupará também da verificação de catálogos de exposições relacionadas ao tema retrato e identidade, no sentido de reconhecer o contexto artístico de minha produção, bem como de textos que acompanham esses catálogos e que possam trazer informações relevantes e novas referências bibliográficas para o campo de minhas reflexões.

- Pesquisa Documental: Esta pesquisa se ocupará sobretudo da verificação de documentação relacionada às obras do parâmetro interno da criação. Fotos do período de cessão da Fotomática para o trabalho artístico (1987), textos pessoais redigidos à época, o material sobressalente daquela pesquisa e o projeto-piloto de Auto-Objeto, que gerou toda a série, fornecerão subsídios para estudo dos métodos heurísticos e compreensão das intencionalidades em curso.

- Pesquisa de Laboratório: este procedimento metodológico é importante para a realização da pesquisa criativa, em sua faceta interdisciplinar Arte/Tecnologia. A produção das obras interativas solicita uma prática no que se refere à preparação das imagens (fotografias digitalizadas) e procedimentos tecnológicos que viabilizem o alcance adequado daquela qualidade das novas tecnologias, a interatividade, que passa por uma pesquisa dos softwares e hardwares necessários para a criação e execução da obra, proporcionando uma instrumentalização para as propostas poéticas.

- Pesquisa Experimental: a investigação empírica é fundamental para esta pesquisa. Nesse sentido, a obra, aberta ao receptor, é o suporte, ela mesma, do fenômeno desejado. Assim, aos novos ensaios produzidos serão incorporadas diversas estratégias dialógicas, participativas ou interativas. As variáveis serão observadas, estudadas e articuladas pelo artista, visando a estabelecer as regras especificas em cada obra produzida para a vertente criativa desta pesquisa. Entretanto, é na etapa de comunicação da obra, com sua inserção no social, que aquelas estratégias efetivamente serão acionadas pelo público.

Vale lembrar que essas diferentes pesquisas serão aplicadas em harmonia, complementandose, exercendo seu papel fundamental para o movimento pendular entre a práxis artística e a reflexão teórica requerida pela pesquisa em seu todo. 


\section{QUADRO TEÓRICO}

Nas diversas relações com o tema, será mobilizada uma bibliografia que o aborda desde seu caráter geral, a Identidade, até o específico, a Identidade Coletiva. A abordagem se dará numa perspectiva artística ${ }^{8}$. Uma referência para esta pesquisa é A Câmara Clara, de Roland Barthes, que trata mais especificamente do retrato, tendo sido uma leitura estimulante em minha produção de auto-retratos, desde Auto-Retrato em Natureza Morta e de Auto-Objeto, gérmen deste presente projeto, pelas reflexões do filósofo francês sobre as relações da fotografia com o seu referente. Já O Desvio Nosso de Cada Dia - a representação do cotidiano num jornal popular, de Antonio A. Serra, resultante de pesquisa de doutorado do referido autor, guarda importância por sua relação com o processo de criação de Sujeitos, concebido alguns anos após minha passagem pelo curso de Jornalismo na ECA-USP, onde tive contato com esse livro, no qual o autor estabelece alguns parâmetros de reflexão sobre a construção da identidade numa perspectiva sociológica e ideológica. Para ampliar a abordagem e estudo do contexto temático, histórico, social e artístico de minha produção fotográfica de auto-retratos, representam fundamental importância os estudos de Tadeu Chiarelli sobre o retrato e o auto-retrato, alguns agrupados no livro Arte Internacional Brasileira, tais como "Identidade/não identidade - sobre a fotografia brasileira hoje" e "A fotografia contaminada", somando-se a esses o texto de catálogo O Auto-Retrato na (da) Arte Contemporânea: Deslocamentos do EU - O auto-retrato digital e pré-digital na Arte Brasileira. Nesse conjunto de estudos, abarcam-se preocupações artísticas sobre o retrato e o auto-retrato na fotografia desde 1950 até nossos dias, com o advento da tecnologia digital, sempre numa perspectiva de compreender o fenômeno do retrato e da identidade em suas implicações artísticas e sociais. Inclui-se também a tese de doutorado de Helouise Costa, Um Olho que Pensa: Estética Moderna e Jornalismo, no qual a autora trata do fotojornalismo e da construção da identidade nacional no período que nos interessa nesta pesquisa. Finalmente, Identidades Virtuais - uma leitura do retrato fotográfico, de Annateresa Fabris, apresenta, entre outras informações relevantes, um estudo amplo sobre a relação da fotografia, desde suas origens, com os processos de representação da identidade (sobretudo social) até sua passagem para a identificação, do retrato policial ao retrato de identidade, que herda daquele a lógica indiciária.

\footnotetext{
${ }^{8}$ tanto fotográfica quanto sociológica, antropológica, cultural e ideológica, na medida em que a literatura a ser aplicada, tal como o tema em questão, prima por seu caráter interdisciplinar, ao qual não convém se furtar.
} 
Para o embasamento sobre as poéticas de abertura ao espectador, é fundamental o livro Obra Aberta - Forma e indeterminação nas poéticas contemporâneas, de Umberto Eco, para a compreensão da passagem do conceito de estética aberta para o conceito de poética aberta, este intencionado pelo artista. Somam-se também Arte e Interatividade: Autor-ObraRecepção, de Julio Plaza e A Recepção no Contexto das Poéticas Interativas, de Monica Tavares, ambos estudos recentes sobre o tema que trarão fundamentos para a compreensão dos mecanismos e procedimentos interativos na arte. Em Plaza, encontra-se uma análise dos principais conceitos e teorias para compreender a relação autor-obra-recepção. O autor, a partir do conceito de obra aberta, de Umberto Eco, enumera três graus de abertura da obra de arte à recepção, relacionando-os com as três fases produtivas da arte (artesanal, industrial e eletro-eletrônica), de grande interesse para o meu projeto multimídia de abertura ao espectador, como poética aberta, participação e interatividade. Monica Tavares, por sua vez, analisa as imagens interativas, tendo em vista a dialética produção/recepção que condiciona a recriação da obra. A classificação das poéticas da obra aberta, as categorias e a especificidade da imagem interativa, bem como a recepção interativa são questões de fundamental interesse para minha pesquisa na medida em que esses subsídios propiciam a organização das novas estratégias participativas e interativas para Auto-Retrato Coletivo. Além disso, na tese de doutorado de Monica Tavares, traça-se um histórico, com fartura de informações e conceitos, desde as raízes da arte aberta à recepção, passando pela arte participativa até o advento da interatividade em nossos dias, com as Novas Tecnologias de Comunicação (NTCs).

Inclui-se também La Poétique de Dostoievski, de Mikail Bakhtin, que trata da obra do romancista russo e estabelece as bases para a compreensão do dialogismo e da polifonia que nos interessam aqui enquanto elementos constituintes de um coletivo dialógico e plural. Já em Estética - Teoria da Formatividade, de Luigi Pareyson, interessa-nos a noção de irrepetibilidade e singularidade da forma do fazer, tanto na produção do objeto artístico pelo artista quanto na sua interpretação e contemplação pelo espectador (Cap.V). A reflexão assim embasada conduz à hipótese de que a inserção da subjetividade formante dos espectadores na obra pode ampliar a noção de pluralidade, diferença e diversidade fundamentais para o alcance do objetivo artístico e científico desta pesquisa.

Para o estudo da recepção, lançaremos mão do livro Pour une Esthétique de la réception de Hans Robert Jauss, cujo pensamento tem base em A Crítica do Juizo de Emmanuel Kant. 
Com isso, estudaremos a conexão entre o juízo estético e o princípio de interação do espectador com a obra. Tendo referência na Poética de Aristóteles, a teoria de Jauss propõe o conceito de katharsis na perspectiva de uma identificação irônica. Além disso, encontra-se na estética da recepção de Jauss o princípio da inversão da aisthesis em poiesis no momento da recepção, fator preponderante em nossa pesquisa, na medida em que por esta inversão os espectadores podem imprimir seu ponto de vista na obra.

No contexto das poéticas interativas, guardam interesse para nossa pesquisa as reflexões de Edmond Couchot desenvolvidas no livro A Tecnologia na Arte: da fotografia à realidade virtual, que contribuirá para a discussão tanto sobre as fotografias digitalizadas quanto as interativas de Auto-Retrato Coletivo, tendo em suas proposições de hibridação sujeito/objeto/imagem outros argumentos favoráveis à comprovação de nossa hipótese, no âmbito das novas tecnologias - daí também a importância de seu texto "Sujet, Objet, Image". Da mesma forma, as reflexões de Jean-Louis Weissberg em Présences à Distance e "SimulerInteragir-S'Hibrider = Le Sujet Rentre sur Scene", nos dão subsídios para considerar que a abertura de $3^{\circ}$ grau para inserção dos espectadores, promovendo essa hibridação com o sujeito, incorpora na obra a voz destes, constituindo a obra num espaço dialógico e polifônico.

Processos Criativos com os Meios Eletrônicos: Poéticas Digitais, de Júlio Plaza e Monica Tavares, insere-se nesta bibliografia por compreender, em sua Primeira Parte "Arte, Ciência e Tecnologia", as questões de geração de imagens desde o artesanal ao digital, presentes neste projeto Auto-Retrato Coletivo por sua característica interdisciplinar e multimídia. Além disso, a discussão dos processos criativos, em sua Segunda Parte "Os Processos Criativos com os Meios Eletrônicos", contribuirá sobremaneira para a reflexão e compreensão do meu próprio processo criativo, cujo descortinar significa um auto-conhecimento privilegiado para a pesquisa criativa prevista no projeto. Além disso, a produção teórica de Júlio Plaza como um todo debruça-se constantemente sobre a relação palavra/imagem e sobre estudos das novas tecnologias, como em Tradução Intersemiótica e A Imagem Digital. Plaza elucida a importância das NTC's por conjugarem palavra/imagem e seus sistemas significantes referência importante para meu projeto em ambiente digital.

Semiótica, de Charles Sanders Peirce, vem complementar minha formação voltada para a teoria semiótica do texto em Literatura: obra importante em minha pesquisa quanto às reflexões sobre o caráter indicial da fotografia e à classificação das imagens interativas, em 
que os conceitos de Ícone, Índice e Símbolo são fundamentais.

Tendo em vista o procedimento de colagem do ensaio Sujeitos, em que manchetes e textos de jornais foram incorporados numa configuração visual, segundo princípios de poesia concreta, enquadra-se nesta bibliografia o plano-piloto Teoria da Poesia Concreta, de Augusto de Campos, Haroldo de Campos e Décio Pignatari. Os autores colocam a dimensão visual (e intersensorial) como de importância fundamental para a fruição do poema concreto: a leitura sintético-ideogramática (o ideograma), sua disposição tipográfica espácio-temporal, a dimensão assumidamente visual da palavra bem como sua totalidade sensível verbivocovisual, envolvendo conteúdo, som, configuração da palavra etc, são aspectos presentes nos ensaios da série Auto Retrato Coletivo e que se ampliam nas versões digitais na internet. Menciono também, Literatura \& Semiótica, de Décio Pignatari; A Arte no Horizonte do Provável, de Haroldo de Campos, bem como Pequena Estética, de Max Bense, e Ideograma: Lógica, Poesia, Linguagem, os dois últimos organizados por Haroldo de Campos. No segundo, encontram-se textos importantes citados na Teoria da Poesia Concreta: "Os Caracteres da Escrita Chinesa como Instrumento para a Poesia", de Fenollosa; e "O Princípio Cinematográfico e o Ideograma”, de Eisenstein.

A revisão bibliográfica também envolve outras obras importantes sobre fotografia, tais como Magia e Técnica, Arte e Política, de Walter Benjamin, Ensaios sobre a Fotografia de Susan Sontag, Máquina e Imaginário de Arlindo Machado, Filosofia da Caixa Preta de Vilém Flusser, A Fotografia Moderna no Brasil, de Helouise Costa e Renato Rodrigues da Silva, $O$ Fotográfico de Rosalind Krauss e, finalmente, Diante da Dor dos Outros de Susan Sontag, publicado em 2003.

No contexto dessas reflexões diversificadas sobre fotografia, auto-retrato, poesia, dialogismo, polifonia, formatividade, abertura estética e poética, tendo como tema congeminador a Identidade Coletiva, inscreve-se o projeto Auto-Retrato Coletivo, enquanto estudo de um objeto artístico aberto ao espectador. 


\section{Auto-Retrato Coletivo: \\ Pó́ticas de Abertura ao Espectador \\ NA [DES]CONSTRUÇÃO DE UMA IDENTIDADE COLETIVA}

A dissertação está organizada em três capítulos.

Na INTRODUÇão, apresento minha poética pessoal como artista-fotógrafo e minha produção artística no contexto do auto-retrato e identidade.

\section{O Primeiro Capítulo: "Auto-Retrato Híbrido entre o Indivíduo e o Coletivo"} corresponde aos antecedentes desta pesquisa e apresenta as obras que contextualizam a pesquisa criativa atual e compõem o Paradigma Interno da Criação: Nus Sem Cabeça, Projeção para Tungstênio e Fluorescentes, Auto-Retrato em Natureza Morta, Auto-Objeto e Sujeitos. A partir do reconhecimento das Poéticas da Sugestão, do Estranhamento e do Distanciamento presentes nessas obras, define-se a hipótese de trabalho no âmbito da Obra Aberta, visando a participação e interatividade na recepção.

No Segundo Capítulo: “O Corpo a Corpo com o Espectador”, apresentam-se as obras participativas da série produzidas na pesquisa, a saber: Auto-Retrato por Metro Quadrado, Auto-Retr_Ato_Coletivo, Especulares \#7, Cabeça Defronte, Performance Corpo Coletivo, cujas estratégias solicitam uma mediação corporal do participante para a execução da obra, mobilizando elementos de uma Poética do Jogo.

\section{No Terceiro Capítulo, “Auto-Retrato Coletivo ON-Line: Presenças Distantes",} são apresentadas as obras AlterEgo, ANDROMAQUIA On-Line e Doe seu Rosto/Give me your Face, que propõem interatividade na série, numa abertura que instaura a relação homemmáquina com mediação instantânea no contexto das Novas Tecnologias de Comunicação, articulando elementos de uma Poética da Ação.

Na Conclusão, "Identidades Utópicas: Identidades Abertas", apresenta-se uma reflexão sobre as poéticas envolvidas na abertura da série à participação e à interatividade, bem como sobre o papel do autor e a noção de identidade coletiva nesse novo contexto. 


\title{
NARDO GERMANO
}

\author{
Auto-Retrato Coletivo: \\ PoÉticas de Abertura ao EsPeCtador \\ NA [DEs]CONSTRUÇÃo DE UMA IdENTIDAde COLETIVA
}




\title{
INTRODUÇÃO
}

\author{
"Ver-se a si mesmo (sem ser num espelho), \\ à escala da história, é um acto recente. \\ [...] É curioso que não se tenha pensado \\ na 'perturbação' (de civilização) \\ que este acto novo traz. [...] Porque a Fotografia \\ é o aparecimento de eu próprio \\ como outro, uma dissociação artificiosa \\ da consciência de identidade." 9
}

Roland Barthes

Em toda a história da arte são fartos os exemplos de auto-retratos do artista como pintor, escultor, gravador ou fotógrafo, que capturam um olhar lançado ao infinito, mas preso ao espelho, enquanto o artista empunha o pincel ou a máquina fotográfica ${ }^{10}$. Refletindo sobre meus próprios auto-retratos, constato curiosamente que nunca me registrei empunhando a máquina fotográfica num "auto-retrato do artista como fotógrafo", nem me catalogando na categoria "profissão: fotógrafo".

Embora a noção de auto-retrato em fotografia comumente já informe que o retratado é o próprio fotógrafo, as questões que me mobilizam ao realizá-los são de outra ordem. Interessam-me aspectos ideológicos, psicológicos, ontológicos, subjetivos, em que a presença de um eu-lírico, certamente herdado de minha vocação de poeta, se faz notar. Nesses ensaios, minha visão do auto-retrato fotográfico e da fotografia ancora-se numa subjetividade crítica em oposição à objetividade óptica do aparelho fotográfico, a despeito do estatuto indicial conferido às imagens por ele produzidas. Cabe considerar que a categoria de índice não confere de per si objetividade ao signo fotográfico. Segundo a semiótica peirceana, o signo, ou representâmen, nunca é o objeto em sua totalidade - representa-o segundo um

\footnotetext{
${ }^{9}$ BARTHES, Roland. A Câmara Clara. Lisboa-Portugal, Edições 70, Col. Arte e Comunicação, vol.12, 1981 (tradução: Manuela Torres),p.28

${ }^{10}$ KraUSS, Rosalind. Lo Fotografico - Por una Teoria de los Desplazamientos. Ed.Gustavo Gili SA 2002, p.94
} 
fundamento:

"O signo representa alguma coisa, seu objeto. Representa esse objeto não em todos os seus aspectos, mas com referência a um tipo de idéia que eu, por vezes, denominei fundamento do representâmen"11

Para Peirce, o Índice é um signo, ou representação, que se refere a seu objeto "por estar numa conexão dinâmica (espacial inclusive) tanto com o objeto individual, por um lado, quanto, por outro lado, com os sentidos ou a memória da pessoa a quem serve de signo"12. Nesse sentido, a associação que comumente se estabelece da indicialidade da fotografia à noção de objetividade não encontra respaldo no contexto da teoria semiótica.

Minhas incursões nos auto-retratos partem da premissa de que, embora de um certo modo a câmera "efetivamente capte a realidade [...], a fotografia constitui uma interpretação do mundo, da mesma maneira que a pintura ou o desenho" 13 e promove um apagamento do referente, posto que não o representa em todos os seus aspectos, mas segundo uma idéia, interpretando-o ou carreando-lhe interpretações pré-determinadas.

Nesse sentido, os meus ensaios fotográficos desenvolvem reflexões metalingüísticas, chegando a propor através de suas imagens que toda foto é um auto-retrato do fotógrafo como, por exemplo, no ensaio Auto-Retrato em Natureza Morta (1985, fig.ARNM-01 a 03), cuja narrativa seqüencial de cinco fotos traz a minha imagem apenas nas três primeiras. A convicção de que não há objetividade na Fotografia permeia meus ensaios fotográficos, sob a égide de um olhar que vê seletivamente, de uma certa perspectiva, e que escolhe o quê

\footnotetext{
${ }^{11}$ PeIRCE, Charles Sanders. Semiótica. Coleção Estudo, São Paulo, Perspectiva.1977 (trad. José Teixeira Coelho Neto), p.46

${ }^{12}$ PeIrCE, Charles Sanders. Semiótica. Coleção Estudo, São Paulo, Perspectiva.1977 (trad. José Teixeira Coelho Neto), p.74

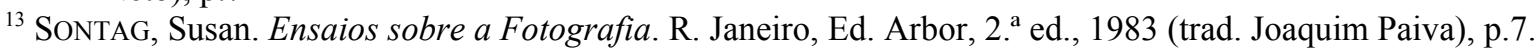


registrar e como registrar segundo uma visão de mundo, uma ideologia, um contexto sóciopolítico, um gosto pessoal, um estado de espírito em particular e/ou jogos perceptivos, sem nenhuma ilusão quanto à objetividade do registro fotográfico. Com uma consciência crítica sobre os mecanismos de manipulação da informação e da realidade, os ensaios revelam, portanto, o fotógrafo sempre presente com sua formatividade ${ }^{14}$ na imagem que produziu mas não numa perspectiva romântica e sim numa correlação do conceito de formatividade de Pareyson com a necessária consideração do contexto histórico numa perspectiva bakhtiniana, correspondendo ao que considero, portanto, uma subjetividade histórica formante, onde subjazem os elementos de um contexto histórico e social, e não apenas um ponto de vista pessoal e alienado daquele contexto.

Nesse sentido, procurando mobilizar as questões ligadas à identidade em seus múltiplos aspectos, a abordagem poética dos meus ensaios fotográficos demanda que se situe, como ponto de partida para reflexão, o contexto histórico e artístico da década de 1980, quando a série Auto-Retrato Coletivo teve início - e sobretudo, parafraseando Walter Benjamin, o contexto de minha pequena história da fotografia pessoal. História que, para fins de concisão, remonta à década de 1950, quando se instauram algumas condições imediatas, e, para fins de reflexão, remonta até a camara obscura no século XV (e por que não dizer à Arte Clássica e à Pré-Histórica?), pinçando alguns tópicos importantes para discussão sobre a fotografia, como o seu estatuto indicial e simbólico, aura, valor de culto e de exposição, objetividade e subjetividade, identidade e identificação, realidade e representação.

Inquietações atuais em torno da fotografia digitalizada... qual seu estatuto? Imagem técnica, imagem tecnológica... em meio a esse hibridismo conflituoso provocado pela

\footnotetext{
${ }^{14}$ PAREYSON, Luigi. Estética - Teoria da Formatividade. R.Janeiro, Petrópolis, ed.Vozes,1993.(trad. Ephraim Ferreira Alves)
} 
passagem da imagem técnica para imagem tecnológica, revela-se-nos o já intuído senão sabido caráter de simulacro da fotografia, flagrado na transducção dos meios. O simulacro do presente denunciando as leis que regem o simulacro do sistema precedente. Tais problematizações conduzem a uma inevitável perda de credibilidade não dos meios produtivos, mas daqueles que detêm seus usos e funções. Não da máquina, o aparelho-coisaem-si. Não do fotógrafo por trás do aparelho-coisa-em-si. Mas, sim, de um Aparelho Ideológico de Estado por trás do fotógrafo e do seu aparelho fotográfico: o aparelho ideológico de informação que embute "através da imprensa, da rádio, da televisão, em todos os 'cidadãos', doses quotidianas de nacionalismo, chauvinismo, liberalismo, moralismo"15, construindo uma falsa consciência do cidadão sobre si mesmo.

Descortina-se então uma questão nevrálgica para o artista-fotógrafo, em meio à subjetividade e aos falseamentos "lícitos" da criação artística (“o poeta é um fingidor”, já dizia Fernando Pessoa ${ }^{16}$ ) no sentido de não impor seu pensamento ou sua voz - sua verdade de artista - nas bases de um discurso monológico, mas de inserir-se poeticamente numa perspectiva dialógica, reflexionante, abrindo-se a um dialogismo que agregue outras vozes, outros pensamentos, outras vias de mão dupla - múltipla.

Que essas manifestações polifônicas se fixem nas obras, emulsionadas, ou que se esvaneçam... mas que ecoem, reverberem na mente de cada receptor como memória, como consciência crítica, como reflexão. E que se propaguem, livres de uma autoridade monológica final sobre esses discursos em trânsito.

\footnotetext{
${ }^{15}$ Althusser, Louis. Ideologia e Aparelhos Ideológicos do Estado. Lisboa, editorial Presença/Martins Fontes, $3^{\mathrm{a}}$ edição, s/d, p.63

${ }^{16}$ PessoA, Fernando. "Auto-Psicografia" in: Cancioneiro. Obra Poética de Fernando Pessoa.. Rio de Janeiro, editora Nova Aguilar SA, 9a edição, 1986, pp.98-99
} 


\section{CAPÍtulo 1 - Auto-Retrato Híbrido entre o Indivíduo e o Coletivo}

\subsection{Pequeno ConteXto Histórico-Artístico}

\subsection{1. - FOTOGRAFIA E IDENTIDADE}

$\mathrm{Na}$ década de 1950, em busca de novas experiências artísticas, a pintura no Brasil exclui do seu universo de interesses o registro do "homem brasileiro" que caracterizava a produção modernista. Dedica-se à discussão de suas especificidades e à exploração de seus limites enquanto arte, legando a continuidade dessa espécie de mapeamento da paisagem humana brasileira à produção fotográfica que se praticava então no país ${ }^{17}$.

Nesse contexto, a fotografia brasileira (que também já vinha se focando na captação de uma imagem do brasileiro) assume para si com grande força documental uma função identificadora. Movidos por essa necessidade "fundamentalmente romântica, apesar de suas conexões insofismáveis com a estética realista", e ancorados no estatuto indicial da fotografia, esses fotógrafos procuravam retratar objetivamente a realidade e assim "criar itens precisos de identidade nacional através de imagens paradigmáticas" que se constituíram ambiguamente como "o registro - ou a construção da identidade do brasileiro" 18 . Essa função identificadora da fotografia documental alcança o período sócio-político repressor da ditadura militar no

\footnotetext{
${ }^{17}$ Esta reflexão tem base in CostA, Helouise. Um Olho que Pensa - Estética Moderna e Fotojornalismo. São Paulo, Tese de Doutorado, FAU/USP, 1998, 2 vol. A autora oferece um panorama que remonta ao jornalismo popular de meados do século XIX e se estende até a Segunda Guerra Mundial, concentrandose no fotógrafo Jean Manzon, apontado como agente na construção de uma certa identidade nacional, no fotojornalismo brasileiro. E também in: CHIARELLI, Tadeu. "Identidade/não identidade - sobre a fotografia brasileira hoje”. In: Arte Internacional Brasileira, São Paulo, Lemos-Editorial, 1999.

${ }^{18}$ CHIARELLI, Tadeu. "Identidade/não identidade - sobre a fotografia brasileira hoje". In: Arte Internacional Brasileira, São Paulo, Lemos-Editorial, 1999, p.132.
} 
Brasil, colocando-se a serviço da construção de um "tipo" nacional ou de uma imagem exótica do brasileiro que se espalhou por páginas de periódicos e cartões postais.

A essa ampla difusão de uma identidade nacional fictícia, apaziguadora e alienante, corresponde um processo de "apagamento" da identidade plural da população brasileira oprimida e marginalizada, num momento em que o estado exercia uma severa coerção dos direitos da cidadania. Anna Bella Geiger (na obra Brasil nativo/Brasil alienígena) e Regina Silveira (com Brazil Today) apropriaram-se desses postais e, numa postura crítica, instauraram diálogos com a realidade maniqueísta construída nessas imagens. Anna Bella Geiger, especificamente, realizou paródias com auto-retratos, fotografando-se a si mesma em cenários urbanos numa reconstituição irônica das cenas idílicas retratadas nos cartões, recontextualizando-as.

\subsection{2. - FotografiA E NÃO-IDENTIDADE}

Nos meados da década de 1980, revela-se entre a intelectualidade nacional uma postura marcada pelo descrédito no "registro" de uma identidade do brasileiro, sobretudo por reconhecer na sociedade o processo contraditório de seu apagamento como ser social ou individual.

Segundo reflexão de Tadeu Chiarelli ${ }^{19}$, esse processo de apagamento da imagem do brasileiro passa a ser deliberadamente explicitado pelos artistas através de seus retratos fotográficos. Caracterizando-se pela recusa da objetividade, a abordagem artística se efetivou em duas vias concomitantes: uma com ênfase no indivíduo e outra com ênfase social.

\footnotetext{
${ }^{19}$ CHIARELl, Tadeu. "Identidade/não identidade - sobre a fotografia brasileira hoje". In: Arte Internacional Brasileira, São Paulo, Lemos-Editorial, 1999, p.132-137
} 
Enquanto "Explicitação do Apagamento da Identidade com Ênfase no Indivíduo", Tadeu Chiarelli considera as obras que colocam em discussão a perda de identidade individual no contexto da sociedade de massas, no sentido de revelar as repercussões íntimas daquele processo de anulação da identidade.

Nessa perspectiva, com enfoque intimista, minha produção na época revela inquietações em torno desse tema. No ensaio fotográfico Nus Sem Cabeça (1981-1985, fig.NSC-01 a 09), inaugura-se uma produção de auto-retratos acéfalos que desloca o foco para "o corpo como primeira marca de identidade" 20 em contraponto aos elementos faciais da identidade social. Nesse ensaio, a nudez do corpo contorcido contra um fundo preto instaura uma não-identidade social do ser que posa, cuja cabeça desaparece sob o efeito de claroescuro do registro fotográfico, com efeito intimista. Em Projeção para Tungstênio e Fluorescentes (1986, fig.PTF-01 a 06), a noção de auto-retrato se constrói a despeito da ausência do próprio autor na cena: a projeção de luzes sem o recurso de filtros de correção altera a temperatura cromática de um fundo infinito neutro, no qual um objeto pessoal (um casaco puído pelo uso apoiado numa cadeira) representa o auto-retratado in absentia. Esses ensaios fotográficos, ao lado do já mencionado Auto-Retrato em Natureza Morta (1985, fig.ARNM-01 a 03) revelam preocupações comuns às de artistas como Rubens Mano, Leila Reinert, Márcia Xavier, Rochelle Costi, Cláudia Jaguaribe e outros.

\footnotetext{
${ }^{20}$ FABRIS, Annateresa. Identidades Virtuais: uma leitura do retrato fotográfico. Belo Horizonte, Editora. UFMG, 2004, pp.157.
} 

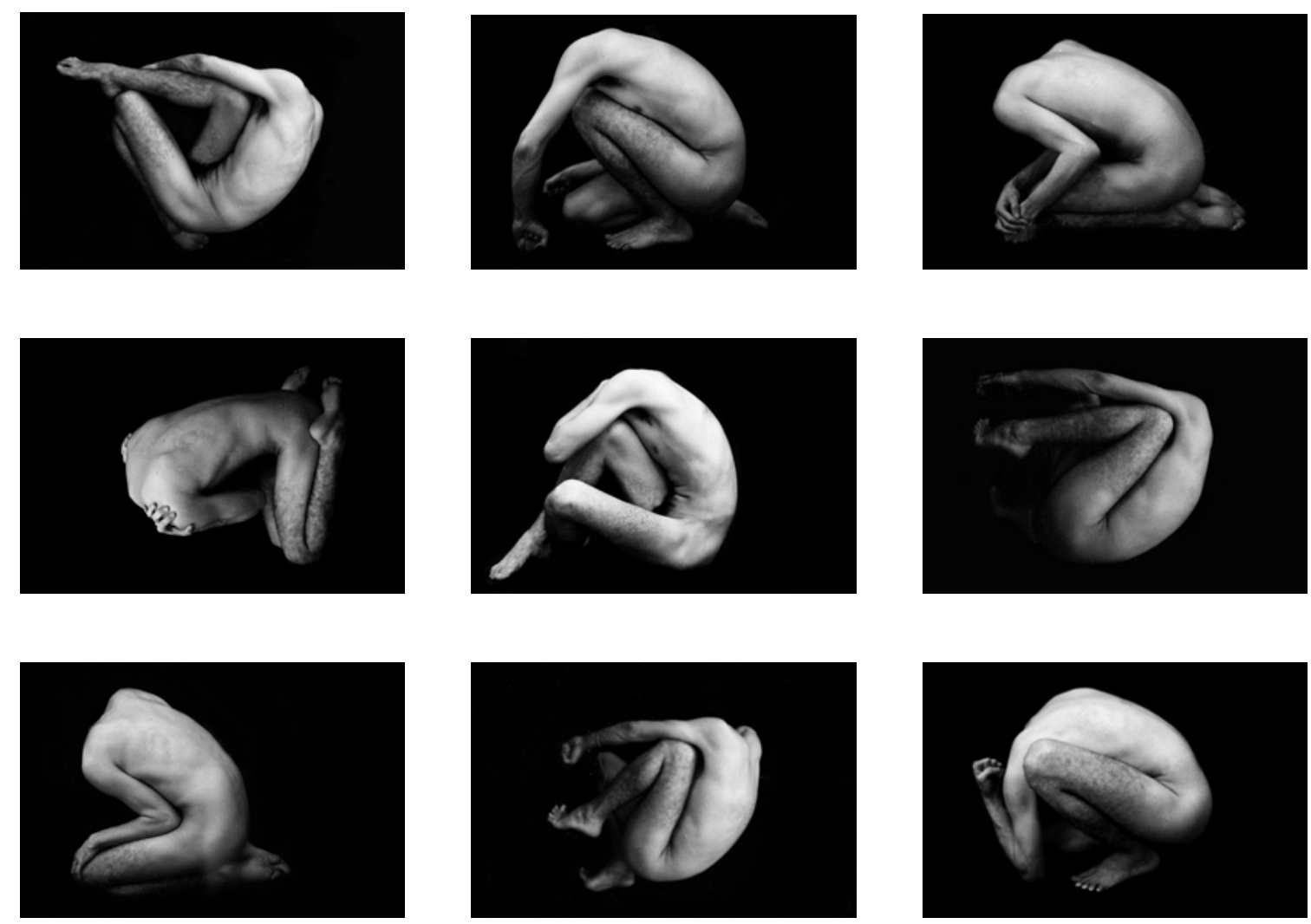

FIG. NSC-01 a 09 - Nus Sem Cabeça, 1981/1985 - Nardo Germano. Auto-retratos acéfalos. 

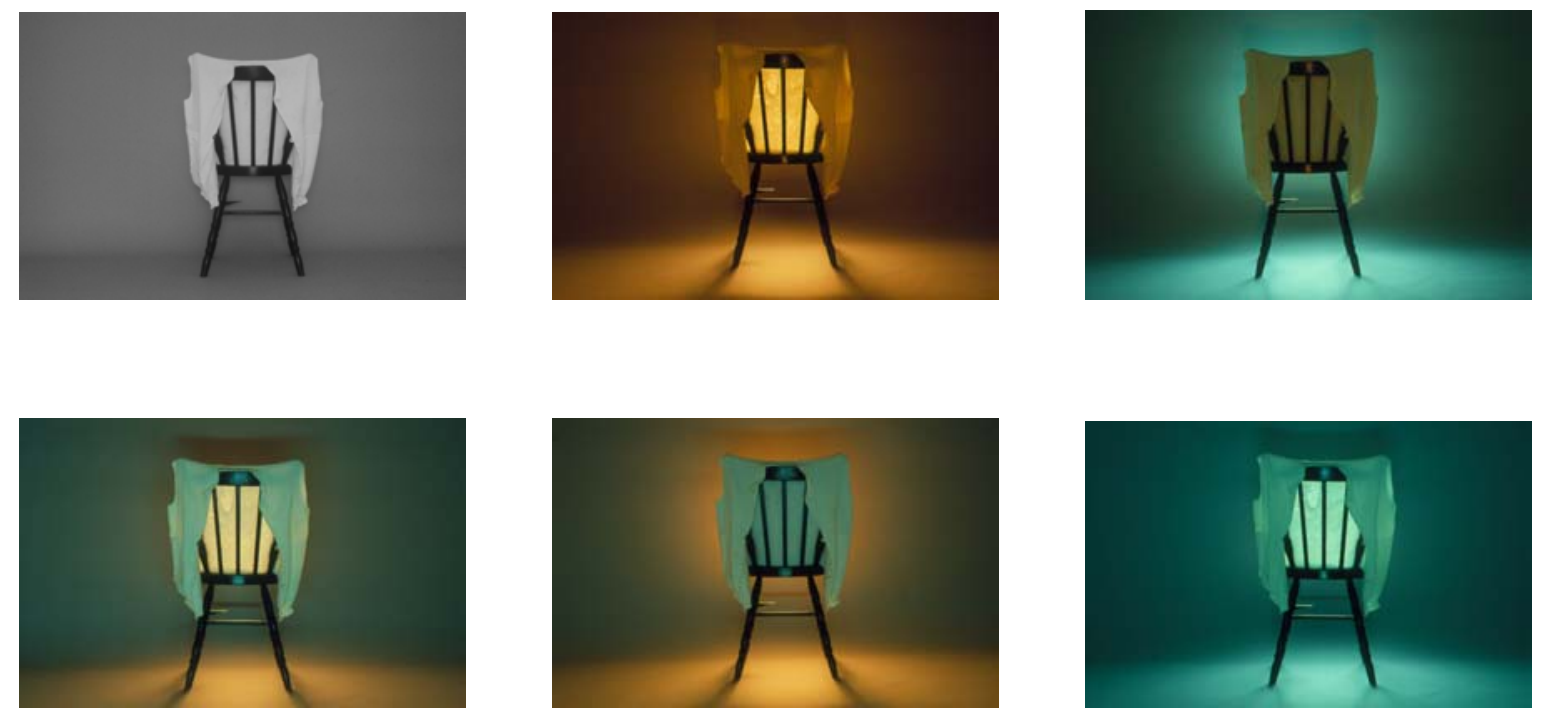

FIG. PTF-01 a 06 - Projeção para Tungstênio e Fluorescentes, 1986 - Nardo Germano. Auto-retrato in absentia. 
Enquanto "Explicitação do Apagamento da Identidade com Ênfase Social", situam-se obras que se contrapõem diretamente àquela função documental da fotografia predecessora e se constituem em mímeses e construções de tipologias que paradoxalmente negam a possibilidade de constituição de uma tipologia concreta da identidade social. Com essa tônica, os auto-retratos que realizei com fotos Fotomática, a partir de agosto de 1987, preocupam-se com os processos de identificação social nas fotos de documentos em Auto-Objeto (fig.ATB01 a 06) e de construção identitária no fotojornalismo, em Sujeitos (fig.SJT- 01 a 9), situandome naquele contexto de atuação artística ao lado de Rosângela Rennó, Cristina Guerra, Cris Bierrenbach, Hélio Mello, Paula Trope, Marcelo Zocchio e outros.

No caso de Auto-Objeto e Sujeitos, os desdobramentos de um ensaio ao outro levaram à constituição inaugural da série Auto-Retrato Coletivo, cunhada por mim em 1987, cujas questões continuaram me inquietando nos anos subseqüentes até os dias atuais. 


\subsection{IDENTIDADE E INDIVÍDUO}

\subsection{1. - Auto-Retrato em NATUREZA Morta ${ }^{21}$}

Atuando na via de uma explicitação do "apagamento" da identidade com ênfase no indivíduo $^{22}$, encontram-se artistas que, através de auto-retratos e retratos do outro, colocam em discussão a perda de identidade do indivíduo e o seu aniquilamento numa sociedade de massas. Realizando registros com enquadramentos de detalhes ou sobreposições, bem como efetuando recortes, fragmentações e segmentações, esses artistas promovem uma ilegibilidade no registro de suas imagens, não identificando a si mesmos ou ao outro em sua plenitude, em alguns casos conjugando o anonimato do corpo à paisagem da natureza ou da metrópole, beirando os limites da abstração.

No ensaio Auto-Retrato em Natureza Morta, a proposta de que toda fotografia constitui um auto-retrato do fotógrafo é o ponto de partida para o desenvolvimento de uma seqüência narrativa em que se revela um processo de apagamento do referente principal do registro: a identidade do fotografado aparece como um spectrum $^{23}$ na cena, resultado de uma exposição longa que registra sua imagem de forma imprecisa(fig.ARNM-01), encaminhando para a desmaterialização de seus contornos como "borrões”(fig.ARNM-02), com uma perda considerável da nitidez da figura humana em oposição ao espaço físico em torno.

\footnotetext{
${ }^{21}$ Auto-Retrato em Natureza Morta é um ensaio de auto-retratos em P\&B que desenvolve o tema "Identidade e Subjetividade no Auto-Retrato". Série composta de cinco fotos ampliadas em 18x24cm cada, papel Kodak H-3 (filme Ilford PB). Essa obra foi realizada em 1985, tendo sido exposta na galeria Focus (1986) e no Centro Cultural São Paulo (1988). Acervo: Focus.

${ }^{22}$ CHIARELli, Tadeu. "Identidade/não identidade - sobre a fotografia brasileira hoje”. In: Arte Internacional Brasileira, São Paulo, Lemos-Editorial, 1999, p.135

${ }^{23}$ BARTHES, Roland. A Câmara Clara. Lisboa-Portugal, Edições 70, Coleção Arte e Comunicação, vol.12, 1981 (tradução: Manuela Torres). Barthes estabelece a distinção Operator/Spectrum/Spectator, respectivamente Fotógrafo/Fotografado/Espectador.
} 


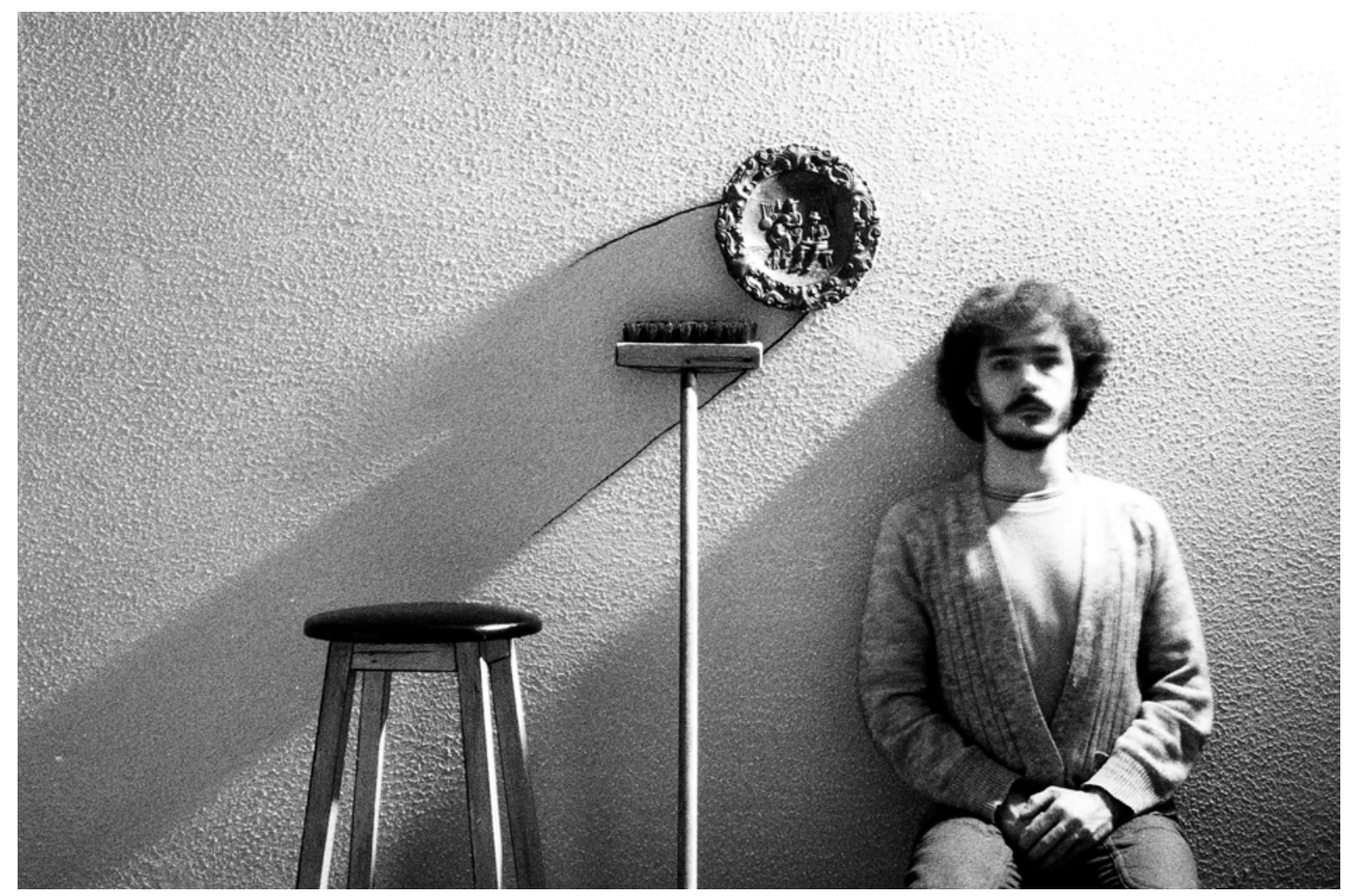

FIG. ARNM-01 - Auto-Retrato em Natureza Morta I, 1985 - Nardo Germano. Galeria FOCUS, 1986 e Centro Cultural São Paulo, 1988. Acervo: FOCUS. 


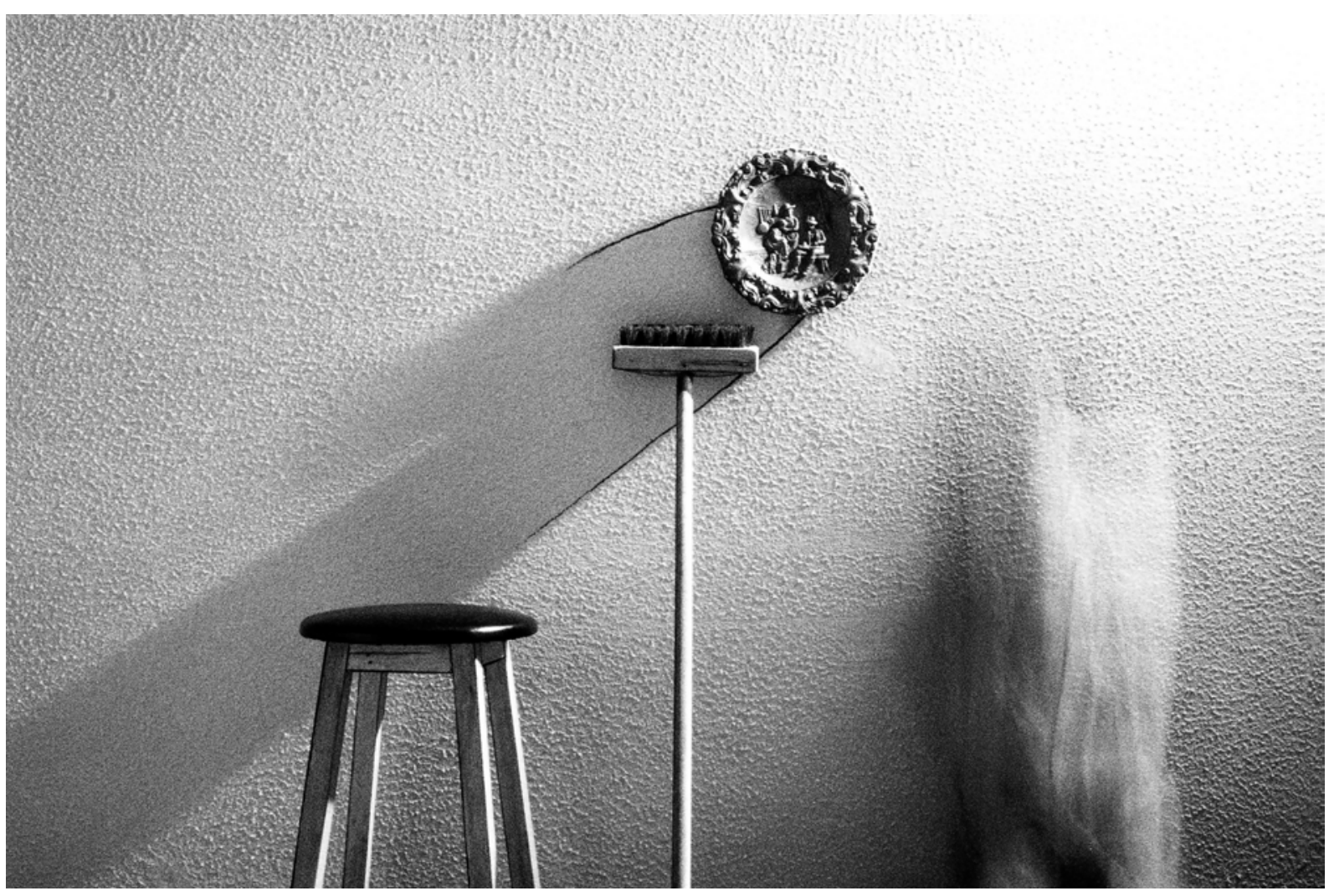

FIG. ARNM-02 - Auto-Retrato em Natureza Morta III, 1985 - Nardo Germano.

Galeria FOCUS, 1986 e Centro Cultural São Pulo, 1988. Acervo: FOCUS. 


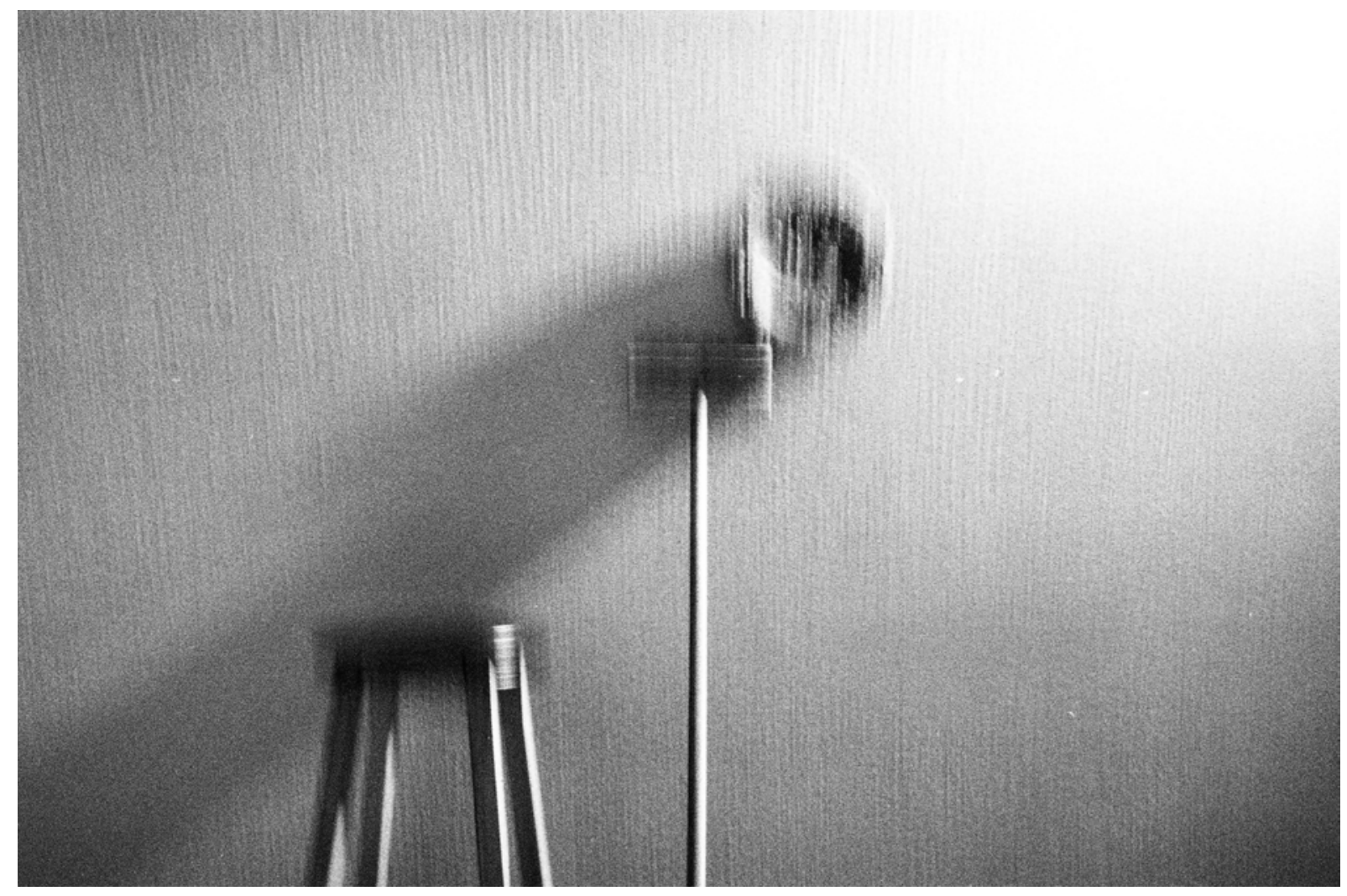

FIG. ARNM-03 - Auto-Retrato em Natureza Morta V, 1985 - Nardo Germano.

Galeria FOCUS, 1986 e Centro Cultural São Paulo, 1988. Acervo: FOCUS. 
Nesse auto-retrato, de caráter intimista e metafísico, a fragmentação do indivíduo destaca-se na escolha do processo de registro e revelação do material fotográfico que atua na emulsão do filme e intensifica consideravelmente sua granulação, interferindo na precisão da imagem obtida e reforçando seu caráter icônico. Nesse caso, a granulação, associada ao efeito borrado da exposição prolongada do movimento, torna-se consideravelmente mais perceptível na figura humana do que nos demais elementos da cena. Esse fator pontua uma identidade imprecisa e pulverizada, cuja subjetividade invade todo o ambiente íntimo(fig.ARNM-03), contaminando-o com seu anonimato. 


\subsection{IDENTIDADE E IDENTIFICAÇÃO}

$$
\text { 1.3.1. - Auto-ОвJето } 24
$$

O contexto em que surgiu a proposta de Auto-Objeto (fig.ATB-01 a 06) foi a criação do Grupo de Ensaios por Millard Schisller em agosto de 1987, para ser desenvolvido no espaço fotográfico da Focus. Convidado para fazer parte desse grupo, e vindo de três ensaios fotográficos realizados anteriormente com o tema auto-retrato ${ }^{25}$, eu aceitei o convite já mergulhado nesse paradigma. O insight para a realização dessa obra brotou de uma situação cotidiana, ao tirar retratos para documento numa cabine Fotomática.

Ocorreu-me a idéia de apropriar-me daquelas imagens ready-made e desenvolver o ensaio de auto-retrato tendo minha Identidade Social como tema. Credito esse insight a um longo período de incubação desde o processo de criação de Auto-Retrato em Natureza Morta (1985) em que realizei inicialmente algumas tomadas frontais, de costas e de perfil diante da objetiva, numa mímese de fotografia de documentos (sobretudo a fotografia indiciária criminalística, como se verá mais adiante), cujas imagens foram descartadas na configuração final do ensaio fotográfico.

Primeiramente, o trabalho foi desenvolvido por minha conta, como "cliente" da Fotomática. Tendo em vista a função identificadora, o estúdio da Fotomática apresentava uma série de limitações à criação, como a iluminação padrão por flash, o fundo neutro, a centralizạ

\footnotetext{
${ }^{24}$ Auto-Objeto é um ensaio de auto-retratos que desenvolve o tema "Identidade Coletiva" em pranchas Fabriano de $0,70 \times 1 \mathrm{~m}$ cada, composto por um total de 835 fotos tiradas em cabine Fotomática. Essa obra foi realizada em 1987, com apoio cultural Focus e Fotomática do Brasil, tendo sido exposta em Recyclic (Focus, 1987) e no Mês Internacional da Fotografia (Oficinas Oswald de Andrade, 1990). Acervo: Focus.

${ }^{25}$ Trata-se dos ensaios Nus Sem Cabeça (19812/85), Auto-Retrato em Natureza Morta (1985) e Projeção para Tungstênio e Fluorescentes (1986), já mencionados anteriormente.
} 


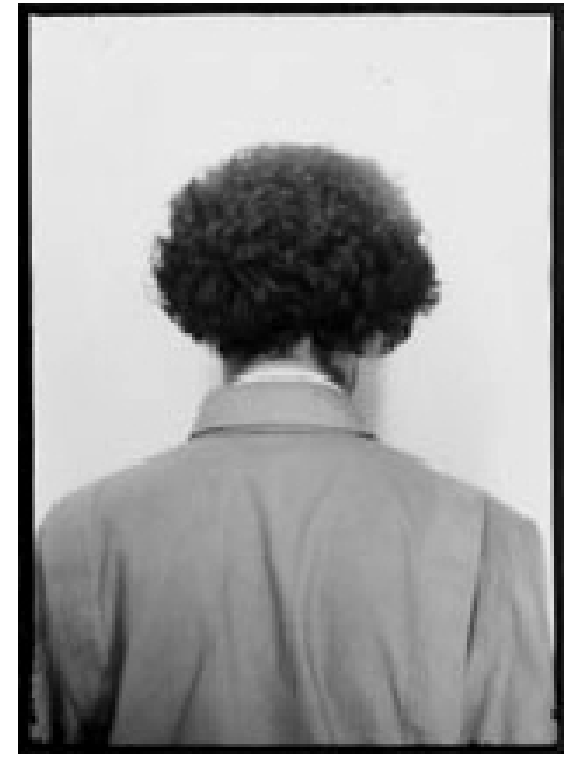

FIG. ATB-01 - Auto-Objeto, 1987: painel \#1 - Nardo Germano. Recy-Clic, 1987 e Mês Internacional da Fotografia - Oficina Osvald de Andrade, 1990. Acervo: FOCUS. 

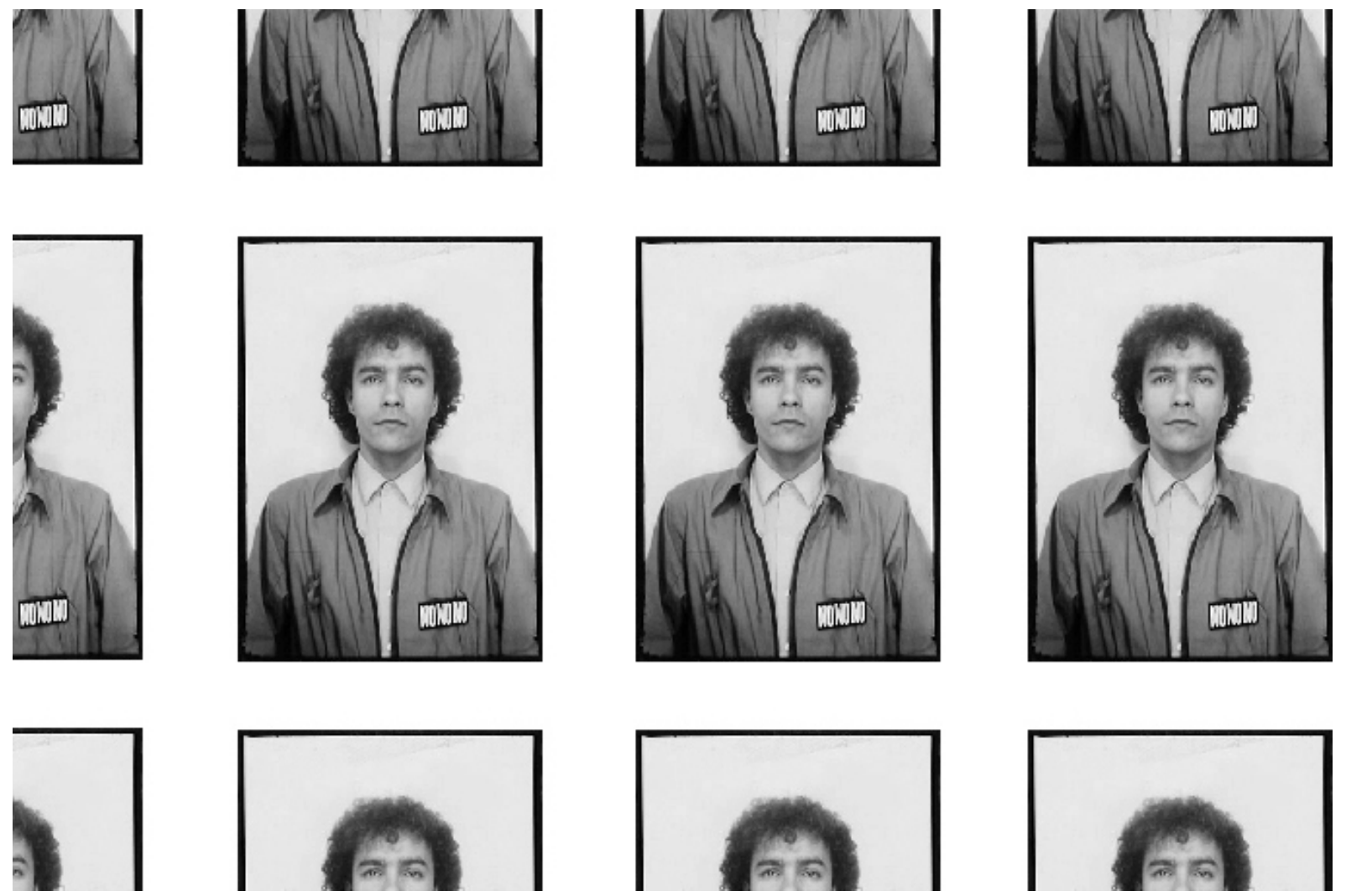

FIG. ATB-02 - Auto-Objeto, 1987: painel \#2 (detalhe) - Nardo Germano. Recy-Clic, 1987 e Mês Internacional da Fotografia - Oficina Osvald de Andrade, 1990. Acervo: FOCUS. 


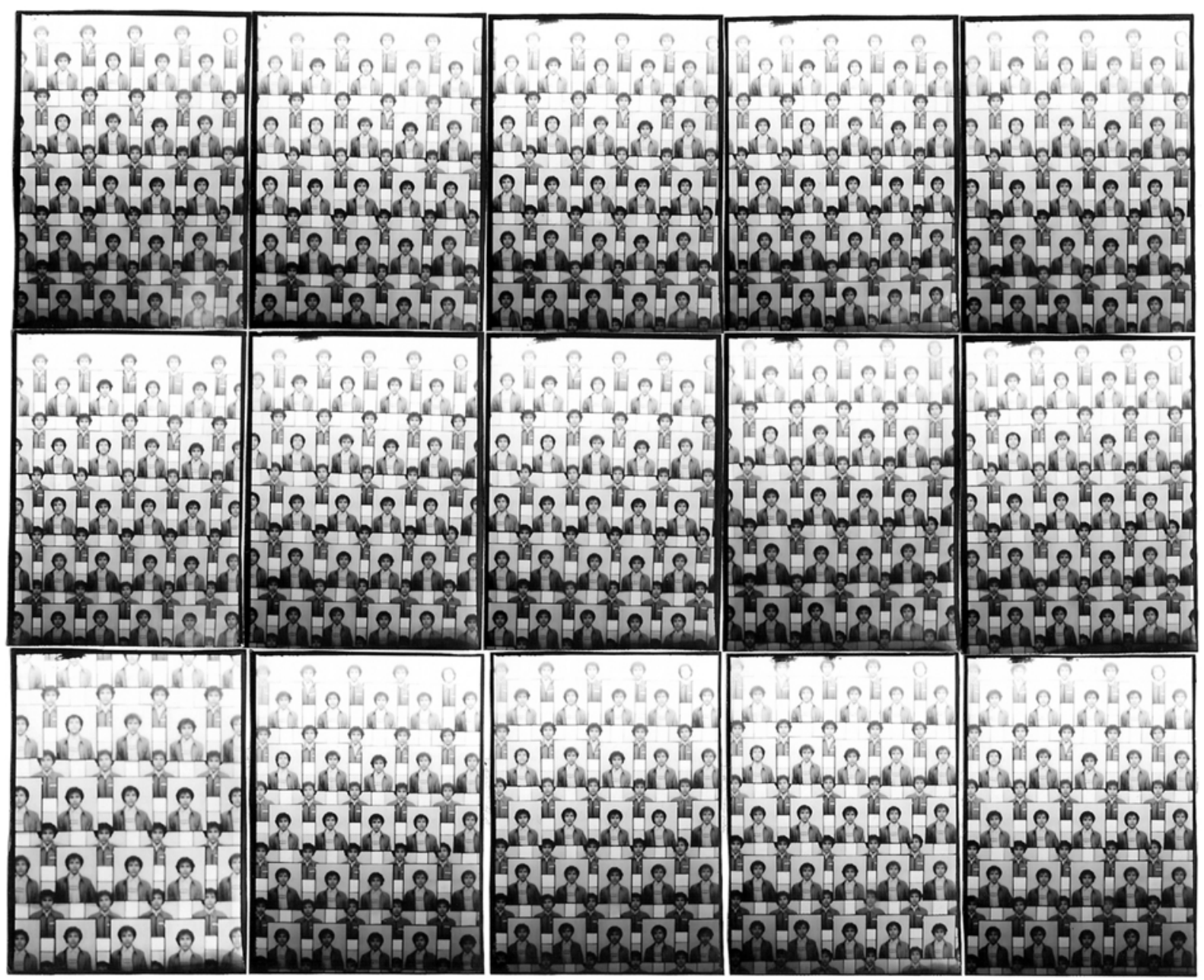

FIG. ATB-03 - Auto-Objeto, 1987: painel \#5 (det.) - Nardo Germano. Recy-Clic, 1987 e Mês Internacional da Fotografia - Oficina Osvald de Andrade, 1990. Acervo: FOCUS. 


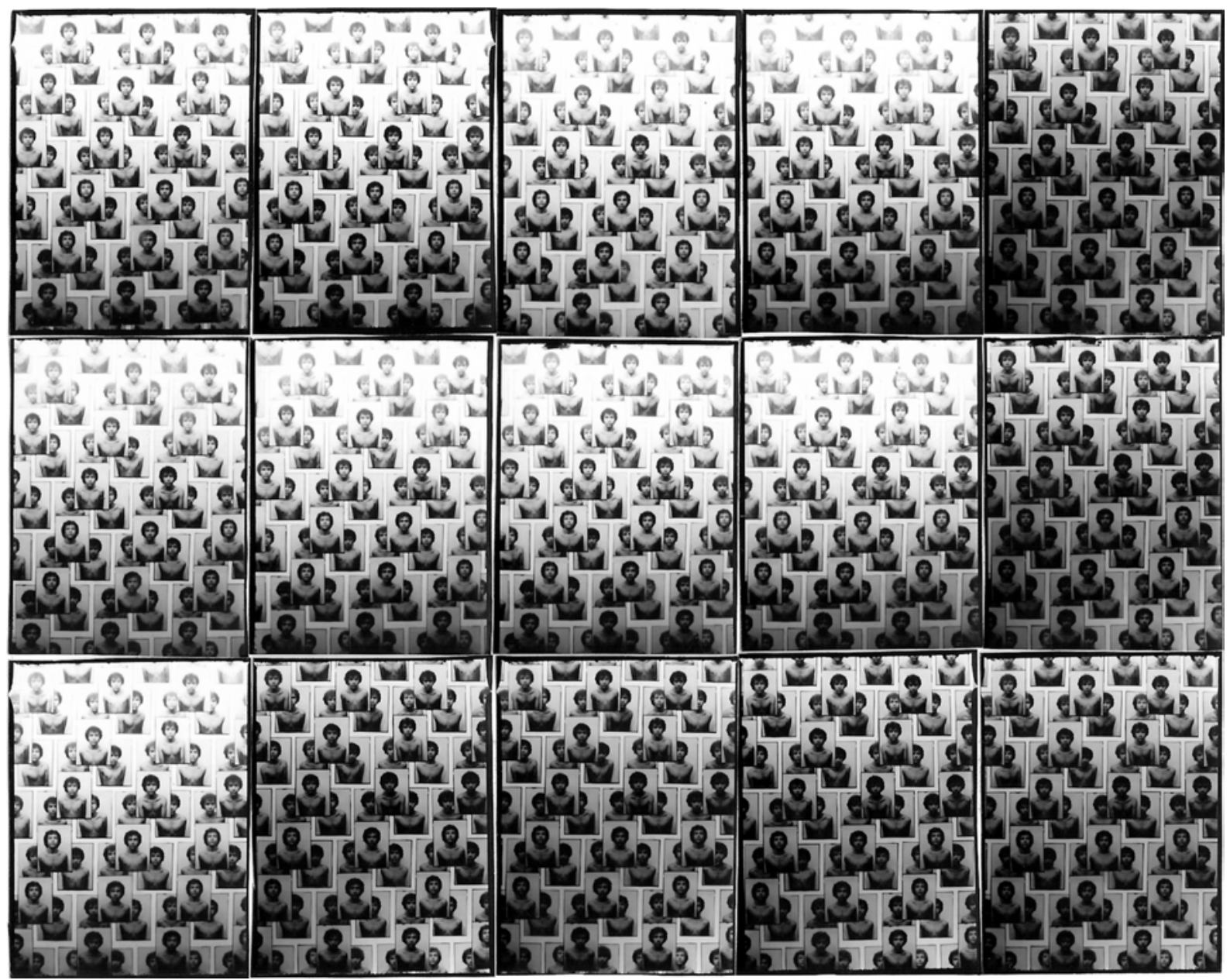

FIG. ATB-04 - Auto-Objeto, 1987: painel \#6 (det) - Nardo Germano. Recy-Clic, 1987 e Mês Internacional da Fotografia - Oficina Osvald de Andrade, 1990. Acervo: FOCUS. 

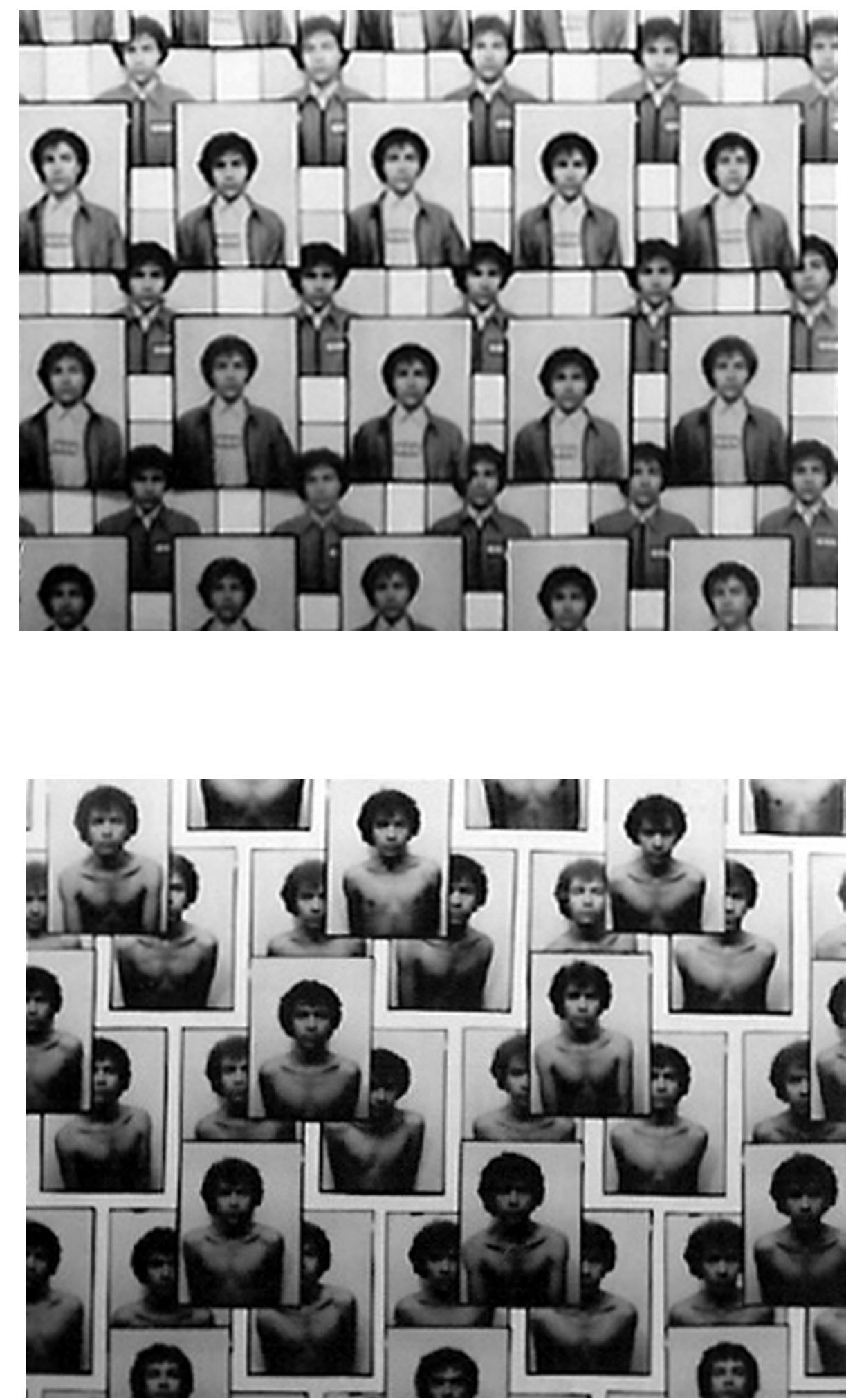

FIG. ATB-05 e 06 - Auto-Objeto, 1987: painel \#5 e 6 (det.2) - Nardo Germano. Recy-Clic, 1987 e Mês Internacional da Fotografia - Oficina Osvald de Andrade, 1990. 
ção da banqueta etc. Sem condições de vencer as coerções do meio, o primeiro conjunto de auto-retratos foi se configurando "conservador", na medida em que não transgredia as limitações apresentadas. A notação da palavra "conservador" entre aspas procura significar que, embora sob o domínio das regras determinantes, o primeiro conjunto de auto-retratos focou-se em experiências de "interpretação" de mim mesmo dentro da cabine, registrando expressões faciais que traziam elementos emotivos em contraponto à objetividade solicitada para o registro. Num segundo momento, contando com o apoio cultural da Focus e da própria Fotomática do Brasil, que cedeu o equipamento para a pesquisa, as reflexões ganharam fôlego com a disponibilidade da cabine e com o incremento da quantidade de imagens obtidas.

No ensaio Auto-Objeto, o tema auto-retrato em minha produção artística sofreu uma mudança de percurso. Até então os ensaios fotográficos haviam sido desenvolvidos em estúdio, num espaço privado, com temática em que o apagamento da identidade se efetuava numa vertente intimista, com ênfase no indivíduo. Se, por um lado, a cabine Fotomática não deixa de ser igualmente um estúdio fotográfico; trata-se aqui de um estúdio inserido no social, no espaço público, com uma função diretamente ligada à identificação social. Por via dessa mudança de perspectivas, usos e funções, o ensaio adquiriu uma ênfase social mais explícita e inaugurou, com a apropriação dessas imagens ready-made como auto-retratos, uma vertente nitidamente preocupada com a relação Indivíduo/Coletivo em minha produção fotográfica.

A identidade abordada por Auto-Objeto, a partir das fotos de Fotomática, mais uma vez não era um "auto-retrato do artista como fotógrafo". Nesse contexto em que "a identidade transforma-se [...] em identificação, num processo de recenseamento social ao qual todos se 
devem sujeitar para ganhar um atestado de existência"26, configurou-se o ensaio de um "autoretrato como cidadão", como indivíduo interpretado pelo viés social que, num jogo metonímico, representa a coletividade. Instaurou-se nesse momento de minha produção de auto-retratos a noção de identidade coletiva associada ao caráter censitário como "a kind of collective self-portrait that serves to reinforce national identity"27, cuja expressão, num movimento de ironia, culminou na denominação do que viria a se constituir uma série de ensaios fotográficos com os auto-retratos da Fotomática:

"Num dado momento submeto meu rosto: objeto fotográfico.

Outros seres, através de mim, encontram expressão.

Sua redundância multiplica-me.

E me transforma em todos: Identidade Coletiva.

Auto-Retrato Coletivo." 28

Obtido no contexto do mercado capitalista, o retrato da Fotomática constituiu-se para mim numa "mercadoria passível de ser eleita como emblema de uma dada situação, real ou fictícia" ${ }^{29}$ que, ao ser apropriado como identidade social, configurou-se numa alegoria do coletivo, na mímese de uma "tipologia de brasileiros" estruturada de forma a revelar dialeticamente a sua inviabilidade.

Colocara-me novamente diante da questão da objetividade na fotografia: o estúdio da Fotomática é uma cabine montada segundo critérios bem definidos e regras pré-determinadas para a obtenção de um registro "objetivo" do retratado, visando à função identificadora para

\footnotetext{
${ }^{26}$ FABRIS, Annateresa. Identidades Virtuais: uma leitura do retrato fotográfico. Belo Horizonte, Editora. UFMG, 2004, p.50-51

${ }^{27}$ StARr, Paul. "The Sociology of Official Statistics" in AlONSO and STARR. The Politics of Numbers New York, Russels/Sage 1983, p. 19. Segue tradução: caráter censitário como "um tipo de auto-retrato coletivo que serve para reforçar a identidade nacional". (t.a.)

${ }^{28}$ Germano, Nardo. Identidade Coletiva em Auto-Objeto (1987) www.nardogermano.com 2004. cf. texto completo: Anexo 1.

${ }^{29}$ Chitarelli, Tadeu. O Auto-Retrato na (da) Arte Contemporânea. Itaú Cultural - Campinas, SP, 2001
} 
fotos de documentos tais como cédulas de identidade e passaporte. O conceito de objetividade em questão parece corresponder à definição de que objetivo é o retrato "do indivíduo que será fotografado de maneira que o resultado fotográfico não seja prejudicado por intenções subjetivas ${ }^{30}$. A lógica de funcionamento da cabine Fotomática responde a essa premissa através da automação, da padronização e da rapidez.

Comumente, a prevenção contra a subjetividade e a opinião, em prol de imparcialidade e objetividade, vale-se do princípio da automação. Essa é a característica fundamental da cabine Fotomática (um Estúdio Fotográfico Automático, mais precisamente), pois não existe o olho humano de um operator ${ }^{31}$ atrás da objetiva. Outra característica é a padronização: a cabine de fundo neutro está provida de uma banqueta giratória para ajuste de altura e enquadramento do busto, segundo ilustração numa das paredes internas. A iluminação está resolvida por flashes frontais: um principal e outro para preenchimento de sombras, o que garante uma iluminação padrão que registra sempre do mesmo modo qualquer pessoa que se sente na banqueta centralizada diante da câmera. Esse princípio nivelador da iluminação e posicionamento é um ponto fixo de referência, que estabelece parâmetros neutros para reconhecimento e catalogação das características fisionômicas individuais, tais como sexo, cor, raça, idade, altura, compleição física etc. A entrega dos retratos, que se dá em questão de minutos, poupa o tempo do cliente e também postula uma isenção final, inviabilizando qualquer trâmite ou serviço para o retoque das imagens, garantindo que as mesmas não passem por nenhum tipo de manipulação depois de capturadas.

Cumpre reconhecer a "caixa-preta" em que se constitui a cabine Fotomática. Nesse

\footnotetext{
${ }^{30}$ Moholy-Nagy apud Sontag, Susan. Ensaios sobre a Fotografia. R. Janeiro, Ed. Arbor, 2.a edição, 1983 (tradução: Joaquim Paiva), pp.117-118.

${ }^{31}$ BARTHES, Roland. A Câmara Clara. Lisboa-Portugal, Edições 70, Coleção Arte e Comunicação, vol.12, 1981 (tradução: Manuela Torres). Barthes estabelece a distinção Operator/Spectrum/Spectator, respectivamente Fotógrafo/Fotografado/Espectador
} 
sentido, o ensaio Auto-Objeto desenvolve-se naquela perspectiva transgressora proposta por Flusser em Filosofia da Caixa Preta, experimentando transgressões às regras e códigos através da desobediência na pose, à adulteração do datador, à alteração da iluminação padrão da cabine, à nudez do busto etc. Surgem assim registros diferenciados por meio dos quais a minha identidade social coloca-se em discussão, ampliando-se criticamente para uma identidade coletiva e questionando os mecanismos institucionais de identificação social e de classe. No contexto dos métodos heurísticos da criação artística, o Método dos Limites ${ }^{32}$, por explorar leis, normas e regras determinantes de um projeto, detectando suas fronteiras de ação, permitiu uma reflexão crítica dos meios de produção, gerando transgressões e transpondo suas limitações à criação. A partir da mudança de condições possibilitada pelo apoio cultural, os procedimentos para execução dos trabalhos passaram para o meu controle, sem a presença de um "funcionário" para proceder aos registros fotográficos. Assim, em minha primeira sessão na cabine sob essas novas condições, girei a banqueta e registrei-me de costas, oferecendo a nuca para a câmera: produziu-se então a imagem inaugural de Auto-Objeto (fig.ATB-01).

Pelo pressuposto de que é possível criar mais do que a linguagem permite, reconhece-se no método dos Limites aquela perspectiva transgressora sugerida por Flusser em Filosofia da Caixa Preta, no sentido de que "o decisivo em relação aos aparelhos não é quem os possui, mas quem esgota o seu programa ${ }^{, 33}$. Com esse propósito, empreendi (experimentando) diversas transgressões às regras e códigos embutidos na cabine, adulterando o datador e o funcionamento do flash, desobedecendo aos códigos comportamentais da pose diante da objetiva, recortando o rosto das fotografias, enfim, desconstruindo seu programa em cada fase

\footnotetext{
${ }^{32}$ Plaza, Julio, Tavares, Monica. Processos Criativos com os Meios Eletrônicos: Poéticas Digitais. São Paulo, Hucitec/FAEP-UNICAMP, p.97

${ }^{33}$ FLuSSER, Vilém. filosofia da Caixa Preta: Ensaios para uma Futura Filosofia da Fotografia, São Paulo, Hucitec, 1985, p.27
} 
de seu processo de funcionamento. Como se pode observar, a aplicação do Método dos Limites se deu em sintonia com o Experimental pois, tendo "implícita a tendência à gratuidade e à curiosidade" 34 , literalmente foram experimentadas as múltiplas possibilidades de ruptura, com a realização concomitante à criação.

A seqüência desenvolveu-se com registros frontais - que se bifurcam em dois grupos: no primeiro, o retratado veste uma jaqueta na qual tem preso um datador com a inscrição "nonono" em substituição à data (fig.ATB-02); no segundo grupo, o retratado apresenta-se com o torso desnudo. A mis-en-scène, empregando recursos de expressão corporal, simula diferentes compleições físicas e estados de espírito, numa atuação brechtiana, fixando diretamente o olhar no espectador ou manifestando uma postura irônica. Nas propostas de distanciamento do teatro de Brecht, a noção de afastamento procura romper as regras da unidade clássica e não promover a identificação do espectador com a trama e suas personagens, de modo a impedir que o público seja tomado pelo transe catártico emotivo que o aliena de seu senso crítico. Walter Benjamin sublinha que uma peça de Brecht "é uma construção que precisa ser vista racionalmente", definindo como gestual o teatro brechtiano: um teatro em que "o gesto é seu material" com tamanha ênfase que "a mais alta realização do ator é "tornar os gestos citáveis"”, instaurando a dialética do teatro épico "no confronto constante entre a ação teatral, mostrada, e o comportamento teatral, que mostra essa ação"35, numa ênfase da função metalingüística da linguagem ${ }^{36}$. Nesse sentido, os auto-retratos de Auto-Objeto revelam uma atitude brechtiana na relação com o processo de registro fotográfico e os códigos de representação da identidade social, provocando condições para uma

\footnotetext{
${ }^{34}$ Plaza, Julio, Tavares, Monica. Processos Criativos com os Meios Eletrônicos: Poéticas Digitais. São Paulo, Hucitec/FAEP-UNICAMP, p.104

${ }^{35}$ Benjamin, Walter. "Que é o Teatro Épico? Um Estudo Sobre Brecht.In:Magia e Técnica, Arte e Política. São

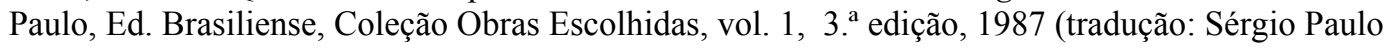
Rouanet), pp.80-.88

${ }^{36}$ Ferrara, Lucrécia D’Aléssio. A Estratégia dos Signos. São Paulo, Perspectiva,1981, pp.39-41
} 
cumplicidade crítica com o espectador.

A composição geométrica dos auto-retratos envolveu um procedimento permutatório intensamente aplicado por conta daquela experimentação que resultou numa profusão de material. Isso tornou a busca de combinações mais dinâmica, rica - e, com o prosseguimento das sessões de fotografia na cabine Fotomática, impraticável. Depois de um exaustivo trabalho de permutação com Auto-Objeto, concluiu-se a seleção e distribuição dos autoretratos que compõem a obra (no material sobressalente, destacou-se um conjunto de autoretratos sem cabeça, que se constituiria mais tarde na matéria-prima para o ensaio Sujeitos).

Organizou-se um conjunto de sete painéis na dimensão $70 \mathrm{~cm}$ por $1 \mathrm{~m}$ cada, em que os auto-retratos se multiplicam num total de 835 fotos dispostas em várias composições geométricas, configurando, assim, uma população de “eus” que, enquanto indivíduos, aspiram utopicamente ao Todo, um "eu" singular que se propõe como metonímia de seu plural "nós".

A partir da constituição do quarto painel, o desdobramento das transgressões dos códigos de identificação social conduz à recodificação dos painéis anteriores, que foram inseridos na cabine e fotografados (fig.ATB-03 e 04). Com a recodificação, aplicou-se o princípio de que "exprimir fenômenos de um modo diferente ajuda a apreender suas implicações" com a introdução de uma "renovação crítica do conceito inicial”37; nesse sentido, a recodificação (antecipada pela disposição geométrica dos painéis anteriores) encaminhou o ensaio na direção de um não-reconhecimento do referente fotografado, na instauração de uma estranheza. Na Teoria do Estranhamento de Chklóvski, postula-se que:

\footnotetext{
${ }^{37}$ Plaza, Julio, Tavares, Monica. Processos Criativos com os Meios Eletrônicos: Poéticas Digitais. São Paulo, Hucitec/FAEP-UNICAMP, p.114-115
} 
"O objetivo da arte é dar a sensação do objeto como visão e não como reconhecimento, o procedimento da arte é o processo da singularização dos objetos e o procedimento que consiste em obscurecer a forma, aumentar a dificuldade e a duração da percepção. $\mathrm{O}$ ato de percepção em arte é um fim em si mesmo e deve ser prolongado; a arte é um meio de experimentar o devir do objeto, o que é já 'passado' não importa para a arte" ${ }^{\text {"38. }}$.

Destaca-se nesse procedimento de recodificação um encaminhamento de Auto-Objeto para a forma absoluta estabelecida no ideal da geometria. Tendo como premissa que a verdade não reside na referência, mas na própria arte, "enfatiza-se a busca de procedimentos poéticos que, ao se efetivarem na adequação entre material e procedimento, procuram fazer sobressair a qualidade sensível, material da obra, causando o estranhamento"39 no seu confronto com o espectador. Nessa dialética entre procedimento e material, "a obra na sua auto-reflexividade mostra-se por eleger como dominante a função poética"40. Se, inicialmente, Auto-Objeto transgride as regras do retrato de documento; agora, com a recodificação, procura também esvaziar as implicações históricas que relacionam a fotografia automática de documentos com a fotografia criminal indiciária, da qual descende ${ }^{41}$ e cujo estigma é tão bem explicitado por Barthes, quando declara que "rien de tel qu'une photo 'objective', du genre 'Photomaton', pour faire de vous un individu pénal, guetté par la police" ${ }^{\text {, }}$, denotando aqui o quanto é difícil escapar das amarras da História. Auto-Objeto propõe assim a possibilidade de um novo devir histórico para o objeto, libertando-o de seu passado como propõe Cklóvsky, na perspectiva de não reproduzir o status quo, mas inová-lo/renová-lo, explorando novas funções não apenas práticas ou utilitárias, mas também estéticas e ideológicas.

\footnotetext{
${ }^{38}$ ChKlovski, V. “A Arte como Procedimento" in: Toledo, Dionisio de Oliveira (org.). Teoria da Literatura: Formalistas Russos. Porto Alegre, ed. Globo, $1^{\mathrm{a}}$ ed. 1973. p.45

${ }^{39}$ TAVAres, Monica. A Recepção no Contexto das Poéticas Interativas. S.Paulo, SP. Tese de Doutorado ECAUSP. 2000, pp.56-57

${ }^{40}$ Tavares, Monica. A Recepção no Contexto das Poéticas Interativas. S.Paulo, SP. Tese de Doutorado ECAUSP. 2000, p.61

${ }^{41}$ FABRIS, Annateresa. Identidades Virtuais: uma leitura do retrato fotográfico. Belo Horizonte, Editora. UFMG, 2004, pp.40-50

${ }^{42}$ BARTHES, Roland. La Chambre Claire: note sur la photographie. Cahiers du Cinéma, Éditions de l'Étoile, Gallimard, Le Seuil, 1980, p 27. Segue tradução: "nada como uma foto 'objetiva', do tipo 'Fotomática', para fazer de você um bandido, procurado pela polícia” (t.a.)
} 
Tendo em mente a necessidade de reunificar as duas seqüências paralelas (nonono e torso nu), um insight trouxe essa conexão necessária, que reunia tanto a possibilidade de retomar a linearidade da seqüência das pranchas quanto de avançar nas reflexões que já vinham sendo desenvolvidas. O desdobramento das transgressões dos códigos de identificação social constituiu-se numa recodificação reiterada dos painéis, que conduziu o ensaio para uma configuração abstrata geométrica, apresentando o referente humano de tal forma reduzido que se constitui numa trama, reforçando a sensação de coletivo e ao mesmo tempo apagando os elementos de individualidade. Esse processo promoveu uma iconização da imagem, reduzindo o referente a uma pequena forma em tons de cinza, da qual não se pode reconhecer se o auto-retratado está vestido ou desnudo - não se pode nem mesmo reconhecer se era um ser vivo ou um objeto o referente que esteve diante da objetiva. O último painel do ensaio, igualmente na dimensão $70 \mathrm{~cm}$ por $1 \mathrm{~m}$, resulta da última transgressão que se efetivou através da fragmentação, pelo recorte de uma minúscula unidade daquela trama, daquele pattern obtido: um retrato de documento reduzido a um motivo impreciso e indeterminado, sem identificação objetiva.

Os auto-retratos de Auto-Objeto promovem uma associação direta com o social ao multiplicar o indivíduo, ampliando as reflexões sobre identidade para a esfera social, da coletividade: a explicitação do "apagamento" de uma identidade social se materializa com os reiterados procedimentos de recodificação dos retratos, até a constituição de uma trama que reduz o referente coletivo aos limites de uma abstração geométrica, perdendo em indicialidade o que ganha em iconicidade. Atuando na via de explicitação do apagamento da identidade com ênfase social, Auto-Objeto contrapõe-se diretamente à função documental da fotografia predecessora da década de 70, criadora de ficções falseadas da identidade nacional. Através da construção de uma tipologia com fotos de documento, instaura uma tipologia irônica em 
sua própria constituição já contestadora, conduzindo à sua negação pela destituição de seus elementos indiciais.

Os artistas que trabalharam nessa vertente, através da realização e/ou apropriação de retratos de pessoas e da alteração de operações técnicas de produção e/ou revelação fotográfica, construíram tipologias no sentido de negar a catalogação do ser numa "tipologia concreta". Apresentam trabalhos que devolvem ao circuito da arte imagens embaçadas, recortadas, encobertas e plurais na representação dos tipos, "pontuando a impossibilidade de registrar o 'brasileiro', imerso numa sociedade esmagada por contradições de toda ordem, onde as grandes massas humanas marginalizadas continuam sem voz nem semblante que as identifique" ${ }^{\text {43 }}$. Nesse grupo, a produção artística exerce uma ênfase no social, refletindo sobre essa identidade marginalizada e recusando-se a compactuar com a imagem típica ou exótica criada pela fotografia documental até então.

Embora o ensaio Auto-Objeto seja composto por auto-retratos e não retratos do outro, sua proposta revela mais afinidade com esse conjunto de obras de artistas que explicitaram o apagamento da identidade com ênfase social, porque desenvolve uma proposta deliberada de simular a construção de uma tipologia para negá-la, em oposição à tradição da fotografia documental identificadora de um "tipo" brasileiro. Considero essa possibilidade por uma correlação com a obra Brasil nativo/Brasil alienígena de Ana Bella Geiger, cujos autoretratos paródicos recontextualizam as cenas idílicas dos cartões postais e que, segundo minha compreensão, se enquadram nessa via: são auto-retratos cuja explicitação do "apagamento" se efetiva no âmbito social em confronto direto com aquela produção identificadora.

\footnotetext{
${ }^{43}$ CHIARELlI, Tadeu. "Identidade/não identidade - sobre a fotografia brasileira hoje". In: Arte Internacional Brasileira, São Paulo, Lemos-Editorial, 1999, p.133-134.
} 


\subsection{2. - SuJEITOS $^{44}$}

“O estatuto de desviante não está fora da norma, mas é a expressão mesma de sua ambigüidade: o desviante não é aquele que lê a norma diferentemente, mas é o que lê na norma aquilo que ela se esforça em ocultar." 45

Antonio A. Serra

Com o impulso da causa motriz - característica do espírito experimental ${ }^{46}$ que se destaca em minha pesquisa criativa com a cabine Fotomática -, cada experiência foi se configurando numa nova obra e em novas possibilidades de experimentação, com uma obra brotando de dentro da outra. Durante o processo de criação de Auto-Objeto, foram produzidos e excluídos de seu corpus um conjunto de imagens, entre elas alguns auto-retratos sem cabeça. Essas imagens foram produzidas por meio de um instrumento próprio para recortar fotos $4 \times 5$ de modo a obter fotos sem margens e cantos arredondados no formato $3 \times 4$. As imagens $4 \times 5$ com o recorte vazado vieram a compor o ensaio Sujeitos (fig.SJT-01 a 09), com retomada da imagística do auto-retrato acéfalo.

Resultantes da experimentação com o material, essas imagens permaneceram em incubação, numa incógnita, enquanto se prosseguia o processo de criação de Auto-Objeto, até que, num momento de insight, visualizei recortes de jornal (manchetes, fotos e notícias) encaixados nos espaços vazados dos auto-retratos e passei a compor colagens com esses elementos heteróclitos.

\footnotetext{
${ }^{44}$ Sujeitos é um ensaio de auto-retratos que desenvolve o tema "Identidade Coletiva". Fotos tiradas em cabine Fotomática + recortes de jornal sobre pranchas Fabriano. Essa obra foi realizada em 1987, com apoio cultural Focus e Fotomática do Brasil, tendo sido exposta em Recyclic (Focus, 1987).

45 Serra, Antonio A. O Desvio Nosso de Cada Dia: a representação do cotidiano num jornal popular. Rio de Janeiro, Ed. Achiamé, 1980, p.23

${ }^{46}$ Plaza, Julio, Tavares, Monica. Processos Criativos com os Meios Eletrônicos: Poéticas Digitais. São Paulo, Hucitec/FAEP-UNICAMP, p.103
} 

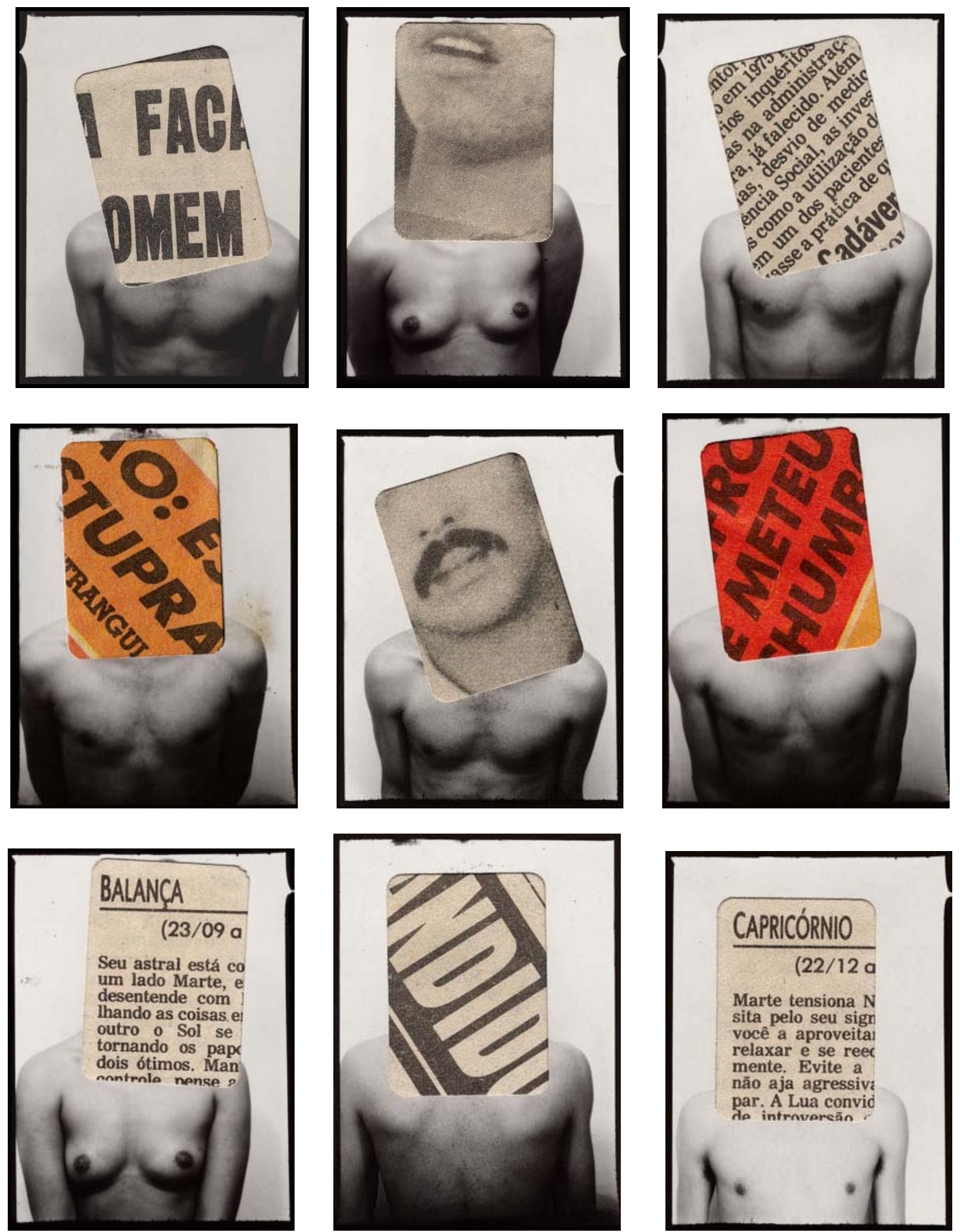

Da esquerda para a direita e de cima para baixo - Sujeitos: obras do corpus imanente da série.

FIG. SJT-01 - Sujeitos, 1987 (detalhe) - Nardo Germano

FIG. SJT-02 - Sujeitos, 1987 (detalhe) - Nardo Germano (na foto: Zilma Barros).

FIG. SJT-03 a 06 - Sujeitos, 1987 (detalhe) - Nardo Germano.

FIG. SJT-07 - Sujeitos, 1987 (detalhe) - Nardo Germano (na foto: Zilma Barros).

FIG. SJT-08 e 09 - Sujeitos, 1987 (detalhe) - Nardo Germano. 
Num procedimento análogo ao de um bricoleur, empregando o método mitopoético ${ }^{47}$, promoveu-se uma apropriação sem plano preconcebido daqueles objetos ready-made. Partindo dos eventos para a estrutura, a construção das colagens foi se realizando gradativamente, por associação, revelando nos fragmentos de notícias e fotos uma concepção resultante do diálogo entre esses elementos e a fotografia de documento. A obra foi se realizando, assim, em função do repertório de um contexto sócio-histórico, a partir da coleta de matéria-prima para as colagens nas edições do jornal "Notícias Populares". Recortar o meu rosto do torso nu e oferecer o espaço vago pareceu-me o gesto fotográfico simbólico de uma busca de reflexão sobre a construção de uma identidade coletiva, flagrada no contexto do mass-media.

Os elementos heteróclitos trazidos pela colagem de manchetes, notícias e fotos de jornal ampliaram a noção de coletivo até então instaurada (eu/eu, eu/todos), reiterando o enfoque social da obra. Além disso, Sujeitos abriu-se para a inserção do "outro" nos autoretratos: duas novas figuras humanas, um torso masculino e um torso feminino nus, alternamse a partir de então entre os meus auto-retratos. Posando na cabine com um trabalho de expressão corporal sob minha própria direção, Zilma Barros (fig.SJT-02 e 07) representa o meu alter-ego feminino, na relação de alteridade masculino/feminino, enquanto Agnus Valente, meu irmão gêmeo, representa minha alteridade particular e pessoal, oscilando entre identidade e alteridade numa perspectiva biográfica. Com essas inserções, ampliou-se a noção de coletivo nos auto-retratos com novas inter-relações possíveis, de cada um consigo mesmo e com os demais (eu/eu, eu/Zilma, eu/Agnus, eu/todos, Zilma/Zilma, Zilma/Agnus, Zilma/todos, Agnus/Agnus, Agnus/todos ...).

\footnotetext{
${ }^{47}$ Plaza, Julio, Tavares, Monica. Processos Criativos com os Meios Eletrônicos: Poéticas Digitais. São Paulo, Hucitec/FAEP-UNICAMP, pp.112-114
} 
$\mathrm{Na}$ criação de Sujeitos, o método dos limites, por conta mesmo do contexto de produção de Auto-Objeto, instaurou-se no embate com as coerções do meio, explorando suas

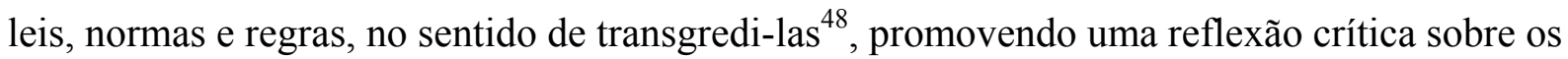
meios de produção. Somou-se aqui a problematização dos meios de comunicação de massas no processo de construção identitária, com o meticuloso trabalho de enquadramento dos textos e imagens para a composição das colagens, no sentido de esvaziar ou conturbar as mensagens dos textos de origem.

Nascido desse processo criativo, o ensaio Sujeitos configurou-se num conjunto de auto-retratos dispostos regularmente, lado a lado, em prancha Fabriano - seguindo o perfil de Auto-Objeto, do qual descende. Por sua dimensão reduzida $(100 \times 70 \mathrm{~cm})$, revelou-se intensamente concentrado em sua energia.

Denunciando o tom sensacionalista de um jornal diário, a composição de fragmentos transporta a carga significativa do seu contexto de origem para a obra. Instaura-se um campo de intertextualidades cujo material é a História e seus "textos". O recorte $3 \times 4$ atomiza as manchetes e notícias num procedimento de Poesia Concreta (fig.SJT-1 e 8), na medida em que emprega "a palavra como objeto" sem abrir mão de suas peculiaridades, mas trazendo, "para o domínio da comunicação poética, as virtualidades da comunicação não-verbal” que "apelam ao nível de compreensão não-verbal do leitor", apresentando-as, sobretudo as manchetes, enquanto "conteúdo-estrutura"49. Além disso, promovem-se reenquadramentos das imagens fotojornalísticas apropriadas em composições fragmentadas, de conotação psicológica, de impacto surrealista (fig.SJT-2 e 5), mas na verdade resultantes de um procedimento dadaísta

\footnotetext{
${ }^{48}$ Plaza, Julio, Tavares, Monica. Processos Criativos com os Meios Eletrônicos: Poéticas Digitais. São Paulo, Hucitec/FAEP-UNICAMP. p.97

${ }^{49}$ CAMPOS, Haroldo. "Poesia Concreta - Linguagem - Comunicação" In: Campos, Augusto e Haroldo, Pignatari, Décio. Teoria da Poesia Concreta. (textos críticos e manifestos 1950-1960) São Paulo, Livraria Duas Cidades, 1975 p. $81-82$
} 
(uma vez que no Surrealismo a colagem é camuflada, enquanto no Dadaísmo, recorte e montagem são explicitados deliberadamente ${ }^{50}$ ).

Explicitando não somente o apagamento da identidade, a obra dá visibilidade a um processo de construção fíccional de uma identidade popular "enquanto categoria potencialmente desviante", como "protagonista da ilegalidade" ${ }^{, 51}$, sob a égide do crime e da violência que domina não apenas as notícias do cotidiano (fig.SJT-03, 04, 06), mas se reitera na página de horóscopos (fig.SJT-07 e 09), sob o princípio de uma suposta irracionalidade e predisposição do leitor à violência. Tendo em conta a reflexão de Tadeu Chiarelli sobre os procedimentos artísticos para a explicitação do apagamento da identidade social ${ }^{52}$, considero a necessidade de uma nova formulação que concebo como uma "Explicitação Crítica da Construção de uma Identidade Social”, que melhor elucida as implicações da obra Sujeitos.

O sensacionalismo, deslocado de seu contexto “jornalístico" original, desmascara-se, pelo contraponto com as figuras de torsos desnudos nas fotos de documento. Nesse agrupamento de contextos, inaugura-se uma polifonia de vozes plurais "et des consciences indépendantes et distinctes" $" 53$ advindas dos diversos contextos sociais em confronto. Daí o plural no título: Sujeitos, seres no trânsito pendular entre a posição de "sujeição à" e a posição de “sujeitos da" História. Propondo-se a redimensionar os sentidos, repudiando o sadismo, a banalização da morte e a indiferença à tragédia alheia, a obra instaura, dialeticamente, um princípio emocional para reflexão sobre a Dignidade Humana que possa se contrapor ao estigma da criminalidade cultivado no jornal popular como identidade coletiva.

\footnotetext{
${ }^{50}$ CHIARELLI, Tadeu. “A Fotomontagem como 'Introdução à Arte Moderna': visões modernistas sobre a fotografia e o surrealismo”. São Paulo, Revista ARS, ECA/USP, ano 1, nr. 1, 2003, p.72

${ }^{51}$ SERrA, Antonio A. O Desvio Nosso de Cada Dia: a representação do cotidiano num jornal popular. Rio de Janeiro, Ed. Achiamé, 1980, p.20-21

${ }^{52}$ CHIARELLI, Tadeu. "Identidade/não identidade - sobre a fotografia brasileira hoje". In: Arte Internacional Brasileira, São Paulo, Lemos-Editorial, 1999, p.133-135

${ }^{53}$ Bakhtin, Mikhail. La Poétique de Dostoievski, édition du Seuil, 1970, p.32. Segue tradução: uma polifonia de vozes plurais "e de consciências independentes e distintas" (t.a.)
} 
Com o duplo ready-made duchampiano, no duplo contexto da identificação, tanto documental quanto fotojornalístico, Sujeitos intenta estabelecer um distanciamento entre o espectador e seus afetos de modo a não promover sua identificação, mas problematizá-la. Assim, busca despertar uma identificação irônica, tendo em vista que "en refusant au spectateur et au lecteur l'identification attendue avec l'objet représenté, on l'arrache à l'emprise de l'attitude esthétique pour le contraindre à réfléchir et à développer une activité esthétique autonome" 54 , pois é sobretudo nesse nível, conforme Jauss, que se atualiza a função de ruptura com a norma.

O processo de envelhecimento dos materiais ao longo dos anos articulou cruzamentos temporais, diacronizando a dimensão crítica sobre os mecanismos de construção de ficções sobre a identidade popular. As diferentes curvas de envelhecimento dos materiais empregados destacam o envelhecimento do papel jornal que se torna parâmetro de comparação para o envelhecimento real do retratado, em oposição à juventude e compleição física em suspenso na foto, num jogo de oposições entre objeto imediato e objeto dinâmico ${ }^{55}$. Os anos se passaram e imprimiram suas marcas no papel jornal, na foto, no artista... O problema da construção ficcional da identidade coletiva continua atual.

\footnotetext{
${ }^{54}$ JAUSS, Hans Robert. Pour une esthétique de la réception. Paris, Gallimard, 1978, p.153 Segue tradução: "recusando ao espectador e ao leitor a identificação esperada com o objeto representado, afasta-o da dominação da atitude estética para forçá-lo a refletir e a desenvolver uma atividade estética autônoma". (t.a.)

${ }^{55}$ PeIrCE, Charles Sanders. Semiótica. Coleção Estudo, São Paulo, Perspectiva.1977, p.62 (trad. José Teixeira Coelho Neto)
} 


\title{
1.4. PÊNDUlo Dialógico
}

Para uma reflexão sobre o caráter dialógico de Auto-Objeto e Sujeitos, na sua relação com o espectador, iniciemos por retomar a distinção de Umberto Eco entre Abertura Estética e Poética da Obra Aberta.

Na Abertura Estética, subjaz o conceito de obra aberta enquanto polissemia no âmbito da fruição da obra. Mesmo que o autor a tenha produzido na expectativa de que venha a ser fruída tal como a produziu, a fruição se efetiva segundo uma perspectiva individual, subjetiva, do fruidor. Nesse sentido, conforme Umberto Eco, podemos dizer que até mesmo

\begin{abstract}
"uma obra de arte, forma acabada e fechada em sua perfeição de organismo perfeitamente calibrado, é também aberta, isto é, passível de mil interpretações diferentes, sem que isso redunde em alteração de sua irreproduzível singularidade. Cada fruição é, assim, uma interpretação e uma execução, pois em cada fruição a obra revive dentro de uma perspectiva original". 56
\end{abstract}

Já nas Poéticas da Obra Aberta, por outro lado, trata-se de uma abertura prevista por uma intenção artística "criticamente consciente dessa realidade" e que, no momento da produção da obra, “em lugar de sujeitar-se à 'abertura' como fator inevitável, erige-a em programa produtivo e até propõe a obra de modo a promover a maior abertura possível",57, intencionalmente requerendo "a ação complementar do receptor no momento da fruição da obra" ${ }^{\text {58 }}$. Assim produzidas, essas obras procuram surpreender o espectador com uma mensagem poética que se apresente "fortemente carregada de informação, por isso mesmo passível de sempre propor-se como uma nova descoberta a ser decodificada, interpretada ou

\footnotetext{
${ }^{56}$ ECO, Umberto. Obra Aberta: forma e indeterminação nas poéticas contemporâneas. Coleção Debates, São Paulo, Editora Perspectiva. 1988 (tradução de Giovanni Cutolo), p.40

${ }^{57}$ ECO, Umberto. Obra Aberta: forma e indeterminação nas poéticas contemporâneas. Coleção Debates, São Paulo, Editora Perspectiva. 1988 (tradução de Giovanni Cutolo), p.42

${ }^{58}$ TAVARES, Monica. A Recepção no Contexto das Poéticas Interativas. S.Paulo, SP. Tese Doutorado ECA-USP. 2000, p. 45
} 
percebida" ${ }^{59}$, instaurando "l'inachèvement de principe, l'ouverture dialogique"60 da obra de arte, conforme propõe Bakhtin.

Auto-Objeto e Sujeitos revelam, em sua vocação dialógica, o concurso múltiplo das modalidades de poéticas que propiciam esse tipo de abertura para recepção, num trânsito livre entre elementos de sugestão, estranhamento e distanciamento ${ }^{61}$. Nesse sentido, para a compreensão dos níveis dialógicos desses ensaios, reconhecemos a necessidade de refletir mais detidamente sobre as poéticas em curso, tendo em vista o conceito de Jakobson de predominância "conquanto um pendor [...] uma orientação",62, numa relação não de exclusividade mas hierárquica, que especifica a obra e elucida seus aspectos mais característicos para reflexão.

\subsection{1. - PoÉtica Predominante EM AUto-OBJETO}

Partindo daquele insight na cabine da Fotomática, o ensaio Auto-Objeto deflagrou-se com a apropriação do retrato ready-made para desenvolver o auto-retrato enquanto identidade social. Além do gesto duchampiano, configura-se aqui a atitude teatral brechtiana dentro da cabine como mais um dado que reitera as intencionalidades de promover um distanciamento

\footnotetext{
${ }^{59}$ Tavares, Monica. A Recepção no Contexto das Poéticas Interativas S.Paulo, SP. Tese de Doutorado ECAUSP. 2000 , p.50

${ }^{60}$ BAkhtin, Mikhail. La Poétique de Dostoievski, édition du Seuil, 1970, p.347. Segue tradução: instaurando "o inacabamento de princípio, a abertura dialógica" da obra de arte... (t.a.)

${ }^{61}$ Ver Tavares, Monica. A Recepção no Contexto das Poéticas Interativas. S.Paulo, SP. Tese de Doutorado ECA-USP. 2000, pp.51-69. Tavares examina essas três poéticas (da sugestão, do estranhamento e do afastamento) que se dão predominantemente na articulação entre as funções da linguagem, respectivamente, fática, poética e metalingüística. Ver também FERRARA, Lucrécia d'Aléssio. “A Obra de Arte Difícil" in: A Estratégia dos Signos. São Paulo, Perspectiva, 1981, onde a autora faz uma abordagem comparativa entre Estranhamento e Afastamento à luz das funções da linguagem.

${ }^{62}$ JAKOBSON, Roman. Lingüística e Comunicação. São Paulo, Ed. Cultrix, 13ª edição, 1988, p.128
} 
crítico, num reforço da função metalingüística da linguagem.

Na organização narrativa dos painéis, por outro lado, a obra apresenta um elemento de sugestão que solicita o prolongamento da atividade receptora pela não-linearidade seqüencial de sua estrutura, com a alternância entre os auto-retratos vestidos e desnudos. Nessa perspectiva, com uma ênfase na função fática, demanda a atenção do espectador no sentido de este ver e rever a seqüência alternada para compreender o seu encadeamento e organizá-la mentalmente. Enfatizando o canal da mensagem "como espaço para se construir significação" com a intenção de "estabelecer no limite entre o uso do código e a forma da mensagem o prolongamento da recepção", o elemento desordenador que se apresenta na obra perturba "o princípio de linearidade da linguagem, quebrando o nexo seqüencial de princípio/meio/fim»ø3 para, assim, desautomatizar a percepção do espectador.

Contudo, o exame da articulação das funções da linguagem, para o reconhecimento da função predominantemente mobilizada pela intencionalidade artística em curso no momento da sua produção, ressalta, em Auto-Objeto, a predominância da função poética caracterizada pelo processo de iconização dos auto-retratos através de sua recodificação. Além disso, as transgressões contra regras e códigos das fotografias de documento resultaram em imagens de relativa estranheza tendo em vista o universo da identificação social no qual a Fotomática está inserida. A rigor, a mais simples dessas transgressões, e talvez a mais óbvia, seja o primeiro auto-retrato de costas para a câmera. Outras transgressões: a adulteração do datador; o posar de torso nu, trazendo para o âmbito formal do retrato de documento a provocação da nudez e, finalmente, a reprodução dos painéis dentro da cabine Fotomática, em que o indivíduo que posa é substituído pelos seus próprios retratos. A função poética evidencia-se, sobretudo, nas

\footnotetext{
${ }^{63}$ Tavares, Monica. A Recepção no Contexto das Poéticas Interativas. S.Paulo, SP. Tese de Doutorado ECAUSP. 2000, pp.51-52
} 
imagens resultantes desses processos de recodificação, reforçando o apagamento da representação pela via da abstração ${ }^{64}$ : busca-se a verdade sobre a identidade social não mais no referente e sim na forma absoluta. Os elementos indiciais são suprimidos em prol do geométrico-construtivo, num processo de iconização das imagens, na perspectiva de "criar uma visão" do objeto "e não o seu reconhecimento"65, colocando o espectador, portanto, numa condição de estranhamento perante a obra. Cabe aqui também considerar um processo de iconização de Auto-Objeto na imediatez de seu conjunto narrativo: à distância, tem-se desses painéis a visão de uma configuração geométrica que, com a aproximação do espectador, revela seus elementos constituintes. E vice-versa, quando da saída do espectador, reiterando, em conseqüência disso, o procedimento da forma absoluta já mencionado ${ }^{66}$.

Em suma, à luz do conceito de predominância de Jakobson, Auto-Objeto aponta analogias com os procedimentos de uma Poética do Estranhamento.

\subsection{2. - PoÉtica PredominANTe em SUJeitos}

Podemos considerar o ensaio Sujeitos um resultado artístico de uma Poética Aberta herdada de Auto-Objeto, de cujo processo criativo emergiu - porém, a incorporação de outros procedimentos poéticos em sua consecução reorganiza a articulação das funções da linguagem, estabelecendo outras relações.

\footnotetext{
${ }^{64}$ TAVAres, Monica. A Recepção no Contexto das Poéticas Interativas. S.Paulo, SP. Tese de Doutorado ECAUSP. 2000, p.67

${ }^{65}$ ChKlovski, V. “A Arte como Procedimento" in: Toledo, Dionisio de Oliveira (org.). Teoria da Literatura: Formalistas Russos. Porto Alegre, ed. Globo, $1^{\text {a }}$ ed. 1973. p.50

${ }^{66}$ Caberia aqui, por esse aspecto, reconhecer já uma vocação para obra em movimento em Auto-Objeto? Uma situação sintomática antecipa essa possibilidade: Na exposição de Auto-Objeto na Oficina Cultural Oswald de Andrade, durante o Mês Internacional da Fotografia, uma cabine da Fotomática foi instalada no espaço, ao lado da minha obra. A FOCUS colocou à disposição uma pequena quantidade de fichas para os interessados experimentarem a máquina e apresentar um projeto pessoal a ser realizado.
} 
Um procedimento próprio da Poética do Estranhamento comparece na realização das colagens, com a estruturação de manchetes, textos e fotos que privilegiam composições difíceis. Já comentamos o procedimento de Poesia Concreta, dado às manchetes e textos. Quanto às imagens fotográficas apropriadas, tendo em vista que a adaptação das idéias literárias de Chklovski "para o campo da fotografia resultou numa visão da realidade dada por imagens fragmentadas, que desafiavam o observador a decifrar uma espacialidade não convencional"67, é possível reconhecer nas colagens de Sujeitos elementos de estranhamento.

Contudo, na predominância do emprego do Método Mitopoético em sua criação, pela reiteração do gesto duchampiano realizado em Auto-Objeto (apropriação das fotos de documento da Fotomática) ao efetivar novas apropriações de fragmentos da realidade préexistente, Sujeitos se especifica em relação ao ensaio que o antecede pela predominância da função metalingüística da linguagem. Com os recortes de jornal, promove-se no âmbito de sua recepção sobretudo uma "experiência de conflito com o objeto" 68 , optando pela inclusão do próprio real na obra. Poderíamos dizer que os gestos duchampianos em Sujeitos buscam:

\begin{abstract}
"atingir o artístico a partir do não-artístico, na proposta de alcançá-lo por meio da ironia, da anarquia, do caos, da entropia e da desordem, como formas de chocar o receptor e, nele, despertar diferentes relações e sentidos. Esta conduta poética, fundamentada sob o ideal do caos e do inconsciente, reproduz o material na sua forma bruta, intencionando despojá-lo dos seus significados convencionais para alcançar novas percepções decorrentes de associações as mais inesperadas" ${ }^{\prime \prime 9}$.
\end{abstract}

Se, de um lado, a Poética do Afastamento apresenta a realidade como matéria bruta de criação (collage); de outro, "reforça ainda o apagamento da representação pelo caminho inverso da abstração", na medida em que, pela tendência objetual observada por Mikel

\footnotetext{
${ }^{67}$ Costa, Helouise. Um Olho que Pensa - Estética Moderna e Fotojornalismo. São Paulo, Tese de Doutorado, FAU/USP, 1998, vol. 1, p.71

${ }^{68}$ Tavares, Monica. A Recepção no Contexto das Poéticas Interativas. S.Paulo, SP. Tese de Doutorado ECAUSP. 2000, p.62

${ }^{69}$ Tavares, Monica. A Recepção no Contexto das Poéticas Interativas. S.Paulo, SP. Tese de Doutorado ECAUSP. 2000, p.64
} 
Dufrenne, "se efetiva pelo excesso de presença" ${ }^{70}$ que se coloca como uma intencionalidade não-artística, ou mesmo anti-artística.

Essa postura característica de uma Poética do Afastamento revela-se predominante em Sujeitos, por sua intencionalidade crítica de distanciamento, de inclusão do não-artístico, de ênfase metalingüística.

\title{
1.4.3. - ENCAMINHAMENTO PARA NOVAs ABERTURAs DiALÓGiCAS
}

A importância de nos determos nesta abordagem sobre as poéticas nessas duas obras encontra respaldo no fato de que podemos assistir, "na caracterização de uma dominante, a uma evolução que atinge a produção de um autor", ${ }^{\text {,1 }}$. Pode-se daí verificar o encaminhamento de intencionalidades de sua produção. Apoiando esta abordagem na reflexão de Lucrécia D’Aléssio Ferrara:

\begin{abstract}
"Parece-nos lícito inferir que de Chklóvski para Brecht assistimos, no cenário da história da arte moderna, a uma evolução que, ultrapassando a função emotiva da arte, atinge a linguagem como dominante, caracterizadora da função estética. Daí chega-se à função metalingüística que deslocaria a dominante, hierarquicamente localizada na linguagem, para o domínio do receptor, isto é, caminha-se, como já foi dito, do específico artístico para a função da arte. Portanto, seria lógico admitir uma hierarquia dominante entre as próprias artes, isto é, na maior ou menor disponibilidade artística para permitir a participação do receptor." 72
\end{abstract}

No desdobramento de Auto-Objeto para Sujeitos, correspondente a uma transição da predominância da função estética (Poética do Estranhamento) para a predominância da função metalingüística (Poética do Afastamento), encontra-se já a vocação da série Auto-Retrato

\footnotetext{
${ }^{70}$ TAVAres, Monica. A Recepção no Contexto das Poéticas Interativas. S.Paulo, SP. Tese de Doutorado ECAUSP. 2000, p.67

${ }^{71}$ Ferrara, Lucrécia D’Aléssio. A Estratégia dos Signos. São Paulo, Perspectiva,1981, p.40

${ }^{72}$ Ferrara, Lucrécia D’Aléssio. A Estratégia dos Signos. São Paulo, Perspectiva,1981, pp.39-40
} 
Coletivo para novas aberturas à participação do espectador. Isto porque, no contexto da construção ficcional de uma identidade coletiva, a questão ideológica contida nos ensaios demandava novas soluções. Com o olhar retrospectivo de hoje, percebemos que essas soluções já estavam intrinsecamente propostas. Reportando-nos a Umberto Eco, justifica-se, portanto, a necessidade de abrir a série a novas formas de participação, na medida em que:

"Quanto mais a mensagem for 'aberta' a descodificações diferentes, tanto mais a escolha dos códigos e subcódigos sofrerá a influência não só da circunstância de comunicação, como das predisposições ideológicas do destinatário." ${ }^{, 73}$

Nesse sentido, é a discussão ideológica da construção da identidade coletiva que solicita novos graus de abertura para inserção do discurso do espectador, para instaurar novas modalidades de diálogo e sobretudo novos pontos de vista, na perspectiva da dialética da utopia e da ideologia proposta por Fredric Jameson, no espírito de que

"uma hermenêutica marxista negativa, uma prática marxista da análise ideológica propriamente dita, deve ser exercida, no trabalho prático de leitura e interpretação, simultaneamente com uma hermenêutica marxista positiva, ou uma decifração dos impulsos utópicos desses mesmos textos culturais ainda ideológicos" ${ }^{\text {"74 }}$.

Certamente, a organização de estratégias de participação ou interatividade não garante de per si a constituição de um discurso dialógico ou polifônico. Mas cumpre instaurar o impulso utópico que o torne possível.

\footnotetext{
${ }^{73}$ ECO, Umberto. As Formas do Conteúdo. São Paulo, Perspectiva/Edusp, 1974 (tradução: Pérola de Carvalho), p.125 (grifo meu)

${ }^{74}$ JAMESON, Fredric. O Inconsciente Político - a narrativa como ato socialmente simbólico. São Paulo, Editora Ática, 1992, p304 (tradução: Valter Lellis Siqueira).
} 


\title{
CAPÍtulo 2 - O CORPO A CORPO COM O ESPECTADOR
}

\author{
"Somos os propositores: \\ Nossa proposição é o diálogo." 75
}

Lygia Clark

As colagens do ensaio Sujeitos desdobraram-se em Auto-retrato por Metro Quadrado, Cabeça Defronte, Auto-Retr_Ato_Coletivo e Especulares \#7. O ponto em comum entre esses ensaios é a continuidade de uma crítica à construção de uma tipologia de identidade coletiva, contando, nesta etapa, com estratégias de inserção do espectador, que solicitam sua “participação mediada corporalmente" ${ }^{76}$ na execução da obra.

A noção da participação está relacionada à noção de abertura da obra à recepção ${ }^{77}$, bem como às três fases produtivas da arte - artesanal, industrial e eletro-eletrônica -, devendo ser pensada nesses termos de modo a se compreender historicamente a relação autor/obra/recepção ${ }^{78}$. Neste novo contexto, efetiva-se na série Auto-Retrato Coletivo uma recepção com abertura de segundo grau, que se identifica "com as alterações estruturais e a variedade temática (social, orgânica, psicológica) para promover atos de liberdade dos espectadores sobre a obra que chama à participação",79. A noção de "arte de participação" denota uma tendência para encurtar a distância entre criador e espectador, na qual a obra se constitui como mediação. As estratégias de participação solicitam ou induzem o espectador a

\footnotetext{
${ }^{75}$ CLARK, Lygia.. Lygia Clark, Rio de Janeiro, edição Funarte, 1980, p.31

${ }^{76}$ TAVAres, Monica. A Recepção no Contexto das Poéticas Interativas, S.Paulo, SP. Tese de Doutorado ECAUSP. 2000, p.73-74. No âmbito das poéticas da participação, Tavares distingue a participação mediada corporal, automática e instantaneamente. pp.74-101

${ }^{77}$ Eco, Umberto. Obra Aberta, Coleção Debates, São Paulo, Editora Perspectiva. 1988 (trad. Giovanni Cutolo)

${ }^{78}$ PlAZA, Julio. Arte e Interatividade: autor-obra-recepção, 2000, p.10 Acessado em 25/06/2003 [http://www.plural.com.br/jplaza/texto01.htm].

${ }^{79}$ PLAZA, Julio. Arte e Interatividade: autor-obra-recepção, 2000, p.5 Acessado em 25/06/2003 [http://www.plural.com.br/jplaza/texto01.htm].
} 
manipular a obra e/ou interferir em seu ambiente, quando então a obra se executa. Nessa perspectiva, por sua multiplicidade de organizações, a obra mostra-se "sempre como uma reconstrução variável de sua própria estrutura" ${ }^{\sharp 0}$, que ocorre pela solicitação do corpo do espectador e não somente de seu olhar ${ }^{81}$. Possibilita-se uma apreensão renovada de significados a partir da "rearticulação dos significantes imanentes a sua estrutura" ${ }^{\text {, }}$, com diferentes aparições da obra.

Tendo em vista a idéia de participação como prestação ou performance, reconhece-se na participação mediada corporalmente uma espécie de jogo que introduz um estado estético que se desdobra em prazer, ou desprazer, na confluência entre o sensível e o inteligível. Aqui, a noção de prazer se constitui no efeito do jogo estético, como um "componente, entre outros, da experiência estética da arte, mas sujeito ao eixo central dessa experiência, que não é senão o jogo da representação" ${ }^{\text {83 }}$. Por essa interrelação entre o movimento do espectador como performance e do prazer como efeito do jogo estético, a participação do espectador se efetiva na conversão da aisthesis para uma poiesis ${ }^{84}$ que se configura como uma Poética do Jogo.

Na Poética do Jogo, a obra em movimento constitui-se "como um campo de possibilidades a ser experimentado" 85 pelo espectador. Nessa perspectiva, "sem um plano concebido e ante a vacuidade mental, as possibilidades de seleção e combinação são praticadas com base num jogo livre de associações", enquadrando-se "na diretriz operacional

\footnotetext{
${ }^{80}$ TAVAres, Monica. A Recepção no Contexto das Poéticas Interativas, S.Paulo, SP. Tese de Doutorado ECAUSP. 2000, p.70

${ }^{81}$ PLAZA, Julio. Arte e Interatividade: autor-obra-recepção, 2000, p.10 Acessado em 25/06/2003 [http://www.plural.com.br/jplaza/texto01.htm].

${ }^{82}$ TAVAres, Monica. A Recepção no Contexto das Poéticas Interativas, S.Paulo, SP. Tese de Doutorado ECAUSP. 2000, p.70

${ }^{83}$ Leal, José Garcia. Arte y Experiencia, p.155-159 apud TAVARES, Monica. A Recepção no Contexto das Poéticas Interativas, p.76 (tradução da citação: Monica Tavares)

${ }^{84}$ JAUSS, Hans Robert. Pour une esthétique de la réception. Paris, Gallimard, 1978. pp.123-157

${ }^{85}$ TAVARES, Monica. A Recepção no Contexto das Poéticas Interativas, p.76
} 
das poéticas da experimentação" ${ }^{" 86}$ em que o processo se encaminha da prática à teoria. Nessa atitude marcadamente experimental, “observa-se o fenômeno para lhe apreender as leis", operando-se "por meio da gratuidade e do espírito lúdico", experimentando-se "a partir de fatos, por indução" ${ }^{87}$, reconhecendo na obra as regras que o convidam a participar de sua execução.

Nesse sentido, evidencia-se em Auto-Retrato Coletivo a noção de obra em movimento como arte processual que, buscando o engajamento ou a intervenção do receptor mobilizado pelo impulso do jogo, tende a priorizar o próprio ato de construção e não necessariamente a constituição de uma obra acabada.

\section{1 - Projeções Identitárias: Jogos de Simulacro ${ }^{88}$}

\subsection{1. - ESPECULARES \#7}

Apresentado no Centro Cultural Maria Antônia em 2004, Especulares \#7 é composto por um conjunto de colagens originais (fig.ESP-01 a 04), num total de 36 fotos, emolduradas sobre fundo preto, sendo 30 colagens com recortes de jornal e outras 6 que apresentam um espelho encaixado no recorte vazado dos auto-retratos acéfalos, promovendo a inserção parcial do rosto do espectador numa composição psicológica de cunho surrealista (reiterando a ambivalência com o procedimento dadaísta que evidencia o recorte e a montagem).

\footnotetext{
${ }^{86}$ Tavares, Monica. A Recepção no Contexto das Poéticas Interativas, p.76

${ }^{87}$ PlazA, Julio \& TAVAres, Monica. Processos Criativos com os Meios Eletrônicos: Poéticas Digitais, p.187

${ }^{88}$ A expressão "jeux de simulacre" empregada por CAILlOIS, Roger. Les Jeux et les Hommes: Le masque et le vertige. Paris, Gallimard, 1958, p.62, pareceu-me adequada ao contexto artístico das obras participativas em questão.
} 

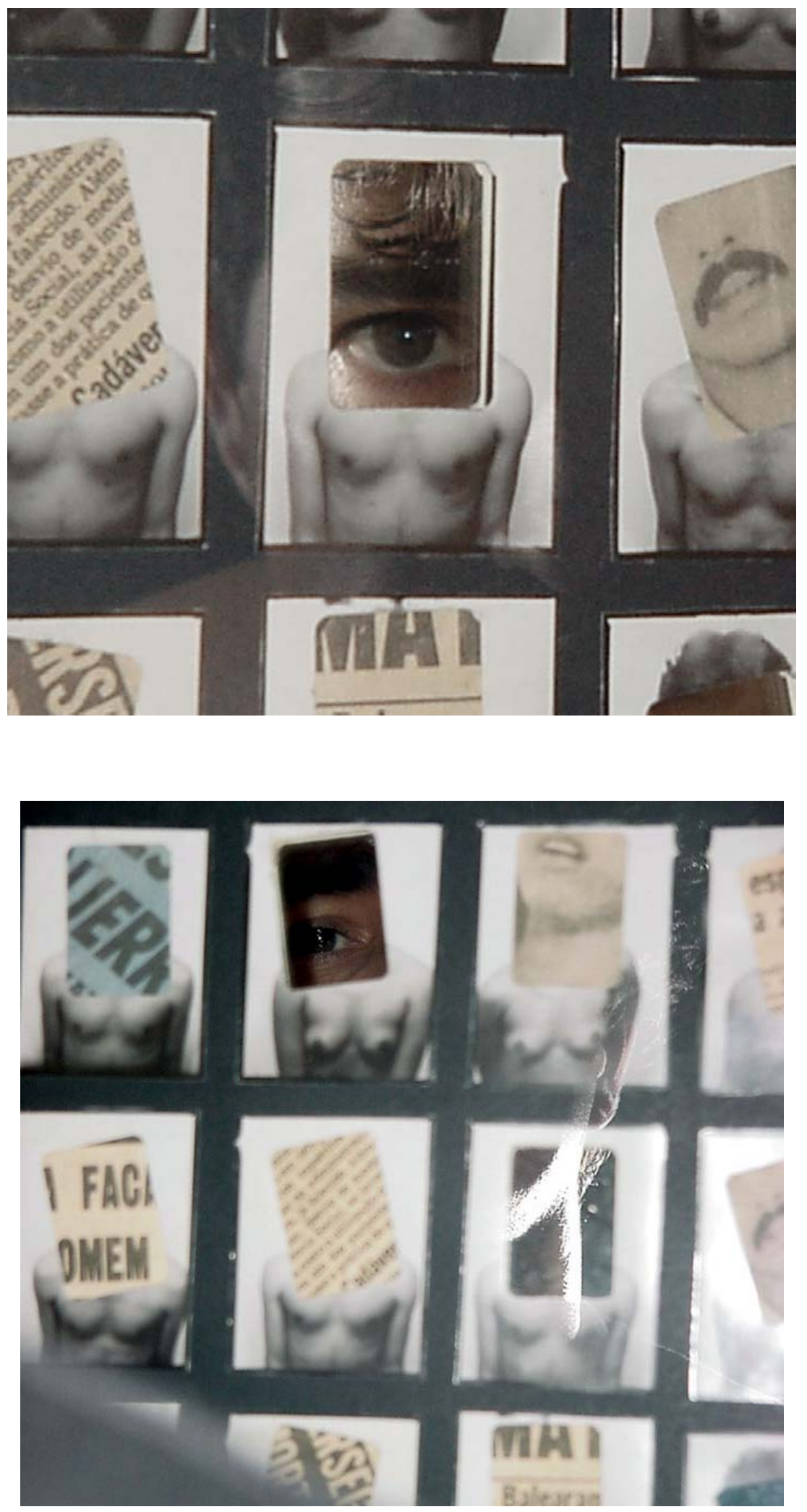

FIG. ESP-01 E 02- Especulares \#7, 2004 - Nardo Germano. Centro Universitário MariAntônia, CEUMA, São Paulo, 2004 e Pinacoteca Benedito Calixto, Santos, SP, 2006. 

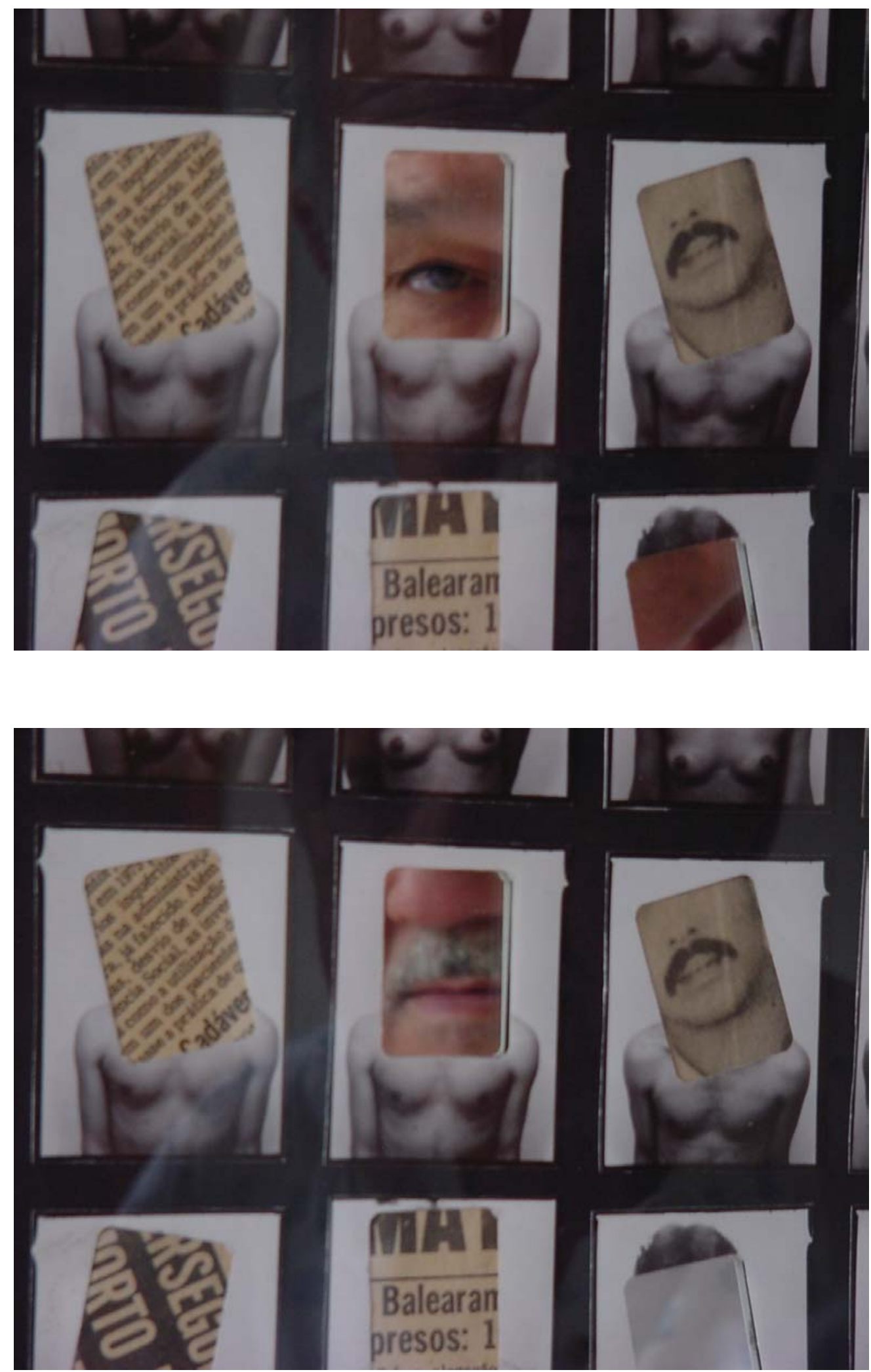

FIG. ESP-03 e 04 - Especulares \#7, 2004 - Nardo Germano. Centro Universitário MariAntônia CEUMA, São Paulo, 2004 e Pinacoteca Benedito Calixto, Santos, SP, 2006. 
A emolduração com vidro sobre o fundo preto cria um espelhamento velado, menos nítido que o do espelho, mas também insere o espectador na obra (fig.ESP-02) pelo reflexo de seu busto como um vulto enquadrado pelas molduras, reproduzindo o formato de uma foto de retrato de documento ampliada na proporção 30x40.

$\mathrm{Na}$ conduta proposta por Especulares \#7, movimentos e gestos do espectador são fundamentais na configuração do ato de sua recepção. Os caracteres autográficos ${ }^{89}$ do participante inscrevem no corpo da obra a configuração singular de seu traço e expressão pessoal. Os espectadores inserem suas reações físicas, seus gestos, movimentos e expressões, numa inter-relação dialógica dinâmica ${ }^{90}$, na medida em que "a essência da apreensão apreciativa da enunciação de outrem, tudo o que pode ser ideologicamente significativo tem sua expressão no discurso interior" cujo processo pode efetuar-se "na situação (interna e externa)" quando por exemplo "um elo se estabelece com a expressão facial"91. Essa réplica interior, ao ser extrojetada, manifesta-se como o ponto de vista do espectador sobre a realidade retratada e também sobre si mesmo, no momento em que este entrevê sua própria reação na superfície especular da obra (fig.ESP-02 e 03).

Assim, a obra forma-se em movimento "como conseqüência da sinergia dos movimentos envolvidos, da combinatória de possibilidades inerentes à materialidade da obra versus a singularidade gestual do receptor" ${ }^{\text {"92 }}$, mostrando-se como acontecimento e vivência, na medida mesma em que é jogada, configurando-se como uma performance, aqui considerada em seu conceito ampliado, incluindo todo o leque das artes em movimento, bem

\footnotetext{
${ }^{89}$ Goodman, Nelson. Los Lenguajes del Arte: aproximación a la teoria de los símbolos, Barcelona, ed. Seix Barral, S.A., 1976 (trad.: Jem Cabanes) pp.123/133.

${ }^{90}$ BAKHTIN, Mikhail. Marxismo e Filosofia da Linguagem. São Paulo, Hucitec, 6 a edição, 1992, p.147-148

${ }^{91}$ BAKHTIN, Mikhail. Marxismo e Filosofia da Linguagem. São Paulo, Hucitec, 6 a edição, 1992, p.147-148

${ }^{92}$ TAVAres, Monica. A Recepção no Contexto das Poéticas Interativas, S.Paulo, SP. Tese de Doutorado ECAUSP. 2000, p.77
} 
como os momentos gestuais e comportamentais das demais artes ${ }^{93}$. Nesse sentido, o corpo se mostra como dinamismo na recepção estética, uma vez que:

\begin{abstract}
“o exercício pleno e contextual das nossas faculdades sensíveis não pode certamente prescindir do movimento, ou melhor, o corpo vivo é antes de mais dinamismo, motoriedade de braços, de pernas, gestualidade confiada a contracções de músculos, a solicitações de nervos; e todas as outras zonas sensoriais são vistas em dependência, como coroamento e integração de uma tal motoriedade primária, que é como que o seu substrato portante ${ }^{94}$.
\end{abstract}

Segundo Tavares ${ }^{95}$, é possivel reconhecer na Poética do Jogo a caracterização de duas tendências antagônicas, propostas por Roger Caillois, que distingue o binômio ludus/paidia enquanto limites opostos de ordem/desordem que, em graus variados de ocorrência, intervêm durante a experimentação do jogo, qualquer que seja sua categoria. Na conduta proposta por Especulares \#7, configura-se uma performance cuja predominância repousa sobre o espírito de ludus, no necessário reconhecimento e cumprimento das regras para deflagrar a performance e assim promover uma renovada execução da obra. Os espelhos, dispostos especialmente ao lado de textos, exigem a aproximação do olhar para sua leitura, de modo que o espectador inadvertidamente encaixe partes do seu rosto na composição pelo reflexo no espelho. A obra explora, nesse primeiro momento, o impulso fundamental aléa ${ }^{96}$, ligado ao acaso. Ao mesmo tempo, as colagens "propõem" possíveis enquadramentos de olho, boca (fig.ESP-04), nariz, para preencher o recorte especular dos auto-retratos acéfalos. A participação se efetiva num segundo momento, na passagem para o impulso fundamental mimicry, na medida em que, ciente da proposta, o espectador complete, agora intencionalmente, as composições surrealistas das colagens de manchetes de jornal. Da mesma forma, a relação se estabelece com o princípio agôn, baseado na competência motora

\footnotetext{
${ }^{93}$ BARILLI, Renato. Curso de Estética, Lisboa, editorial Estampa, 1992 pp.125-126

${ }^{94}$ BARILli, Renato. Curso de Estética, Lisboa, editorial Estampa, 1992 p.124

95 TAVAres, Monica. A Recepção no Contexto das Poéticas Interativas, S.Paulo, SP. Tese de Doutorado ECAUSP. 2000, p.77

${ }^{96}$ CAILloIS, Roger. Les Jeux et les Hommes: Le masque et le vertige. Paris, Gallimard, 1958, pp.55-57
} 
enquanto performance do espectador, tendo em vista que "é na cumplicidade com o corpo (em prestação com os 5 sentidos) que a obra conduz o receptor à reflexão"97. Nessa perspectiva, o ir e vir em direção à obra, o movimentar-se tanto em diagonal quanto lateralmente, e mesmo o expressar-se, conferem à obra uma aparição própria e em constante mutabilidade, segundo os atos de liberdade e, também, de cumplicidade, estabelecidos entre obra/espectador.

Também aqui, a participação mediada corporalmente instaura, pelo impulso mimicry, um confronto de simulacros entre a imagem fotográfica, fotojornalística e especular. Cumpre também salientar que o duplo efeito especular desta obra confere estatuto de performance àquelas "mínimas contracções musculares" citadas por Barilli, como o "ajustamento dos olhos para realizar o acto perceptivo"98. Neste caso, a focalização do olho alterna-se entre a superfície fotográfica e os espelhos que oticamente lançam o olhar na mesma distância adentro em profundidade, onde o espectador se vê. Trata-se de uma performance mais sutil, sem dúvida, mas que reitera o jogo pendular de identidades e alteridades que promove um diálogo entre as várias modalidades de reflexo de sua imagem, em contraponto com os retratos fragmentados das colagens.

\footnotetext{
${ }^{97}$ Tavares, Monica. A Recepção no Contexto das Poéticas Interativas, S.Paulo, SP. Tese de Doutorado ECAUSP. 2000, pp.76-77

${ }^{98}$ BARILLI, Renato. Curso de Estética, Lisboa, editorial Estampa, 1992 p.124
} 


\title{
2.1.2. Auto-REtrato POR METro QuAdrado ${ }^{99}$
}

\author{
"Ao enfatizar a perda da identidade \\ do 'homem brasileiro' ou mesmo do \\ sujeito individual esfacelado na sociedade \\ contemporânea, essa fotografia explicita \\ a sua própria perda de identidade \\ nessa mesma sociedade \\ repleta de novos meios para a \\ ‘duplicação' da realidade.” 100
}

Tadeu Chiarelli

A partir da digitalização das colagens fotográficas originais por meio de scanner, cuja varredura registra a imagem com iluminação homogênea, as imagens de Auto-Retrato por Metro Quadrado (fig.ARMQ-01) foram impressas em papel auto-adesivo laminado, de $18 \times 24 \mathrm{~cm}$, dispostas em $1 \mathrm{~m}^{2}$. A série Auto-Retrato Coletivo absorve algumas problematizações em torno da fotografia no âmbito das novas tecnologias: as colagens de Sujeitos ao serem digitalizadas contribuem para uma nova percepção do simulacro em relação aos ensaios anteriores. A partir da produção artística dos auto-retratos digitalizados, a obra incorpora um diálogo com três gerações ou paradigmas de imagens fotográficas que se contemporizam no novo meio, desde as imagens sem matriz (do Único), passando pelo fotojornalismo (do Reprodutível), até a fotografia digital e, neste caso específico, a fotografia digitalizada (do Disponível). De forma inovadora, os sistemas eletrônicos suscitam novos imaginários e discursos icônicos, redimensionam os sistemas de representação, recodificando as imagens dos sistemas de produção tradicionais (artesanal e industrial), e promovendo transformações na criação e em nossa visão de mundo - o que não significa substituição, mas deslocamentos e incorporações ${ }^{101}$.

\footnotetext{
${ }^{99}$ Auto-Retratos por Metro Quadrado (\#1 exposto na Galeria ACBEU -Salvador, Bahia, em ago/set.2003). Acervo: Galeria ACBEU, Salvador, Bahia (edição 1/10 de Auto-Retrato por Metro Quadrado \#1). [http://www.acbeubahia.org.br/hpp/cultural/gvirtual/materias/materias.htm]

${ }^{100}$ Chiarelli, Tadeu. Arte Internacional Brasileira. São Paulo, Lemos-Editorial, 1999, p.140

${ }^{101}$ Plaza, Júlio e Tavares, Monica. Processos Criativos com os Meios Eletrônicos: Poéticas Digitais, São Paulo, SP, editora Hucitec, 1998, pp.13-26
} 

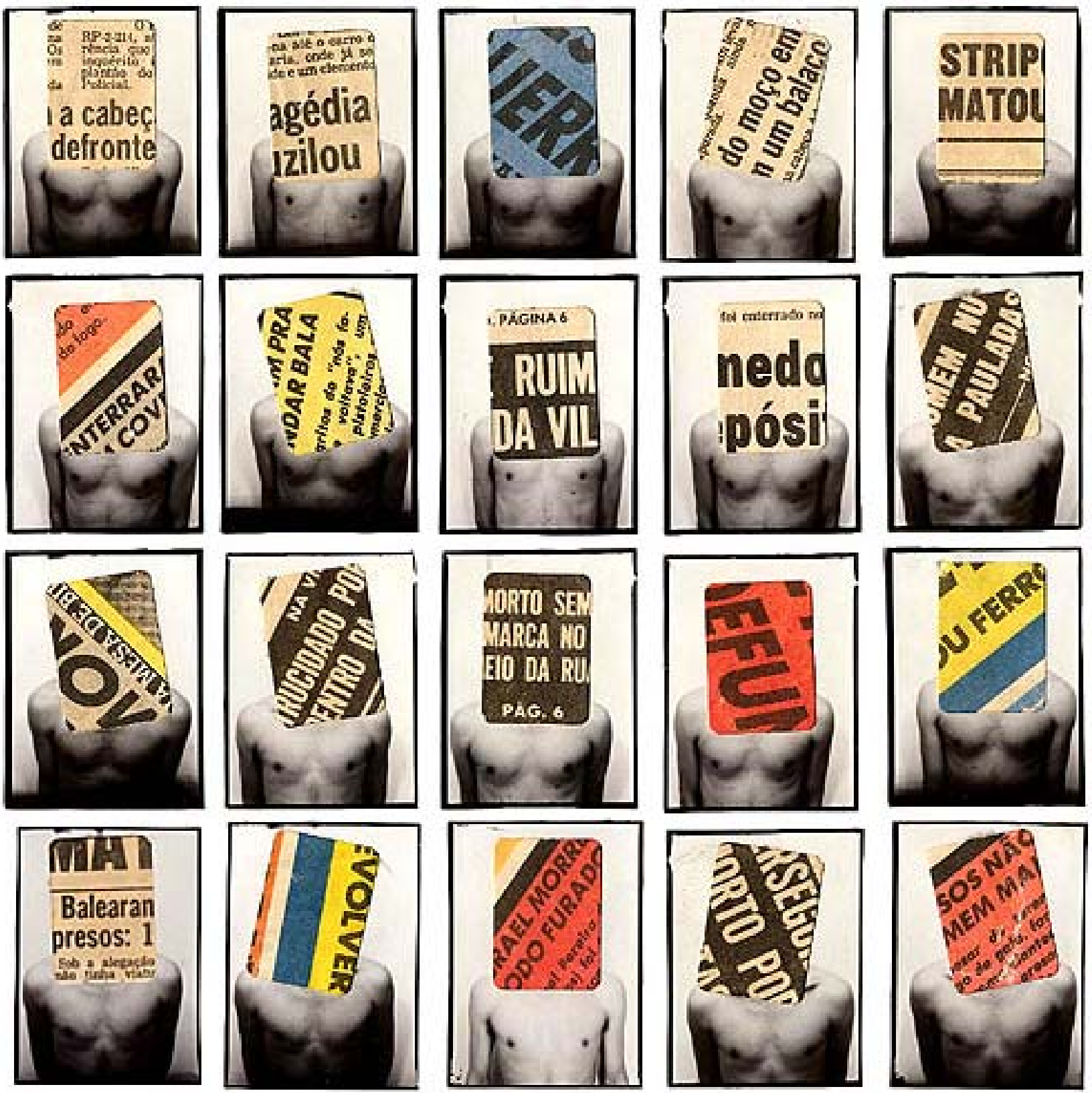

FIG. ARMQ-01 - Auto-Retrato por Metro Quadrado, 2002 - Nardo Germano.

Galeria ACBEU, Salvador, Bahia, 2003. Acervo: ACBEU. 
As fotografias de cabine Fotomática, no contexto histórico da automatização do retrato de identidade, apesar de sua produção industrial, possuem aura tal como os daguerreótipos. Por conta da inexistência de negativos, constituem-se em objetos únicos equivalentes aos da primeira geração de imagens, de produção artesanal. Walter Benjamin sublinha o "valor de culto" conferido aos daguerreótipos, que compartilham essa característica dos meios artesanais, posto que "eram peças únicas" e "não raro, eram guardadas em estojos, como jóias"102. Com a digitalização, procedeu-se à perda da aura das imagens originais bem como das colagens elaboradas em Sujeitos. Reconhecendo a atualidade de Walter Benjamin (como afirma Lúcia Santaella ${ }^{103}$ ), a reprodução da era digital corresponde ao modelo da fotografia tradicional na medida em que "multiplica a reprodução, substitui a existência única da obra por uma existência serial" ${ }^{104}$, potencialmente democratizando sua exibição.

Paralelamente, a materialidade das diferentes "saídas fotográficas" ou "impressões" da imagem em papel denota o caráter híbrido da fotografia digitalizada ${ }^{105}$ que caracteriza seu estatuto de imagem de segunda e terceira geração. Quando apresentada em monitor de vídeo como luz-através, comporta-se como imagem de terceira geração, porém guardando informação fotográfica (de segunda geração). Assim, esses auto-retratos chegam ao espectador contemporizando essas gerações de imagem, atualizando a problemática da construção social da identidade que se estende aos nossos dias, ainda que em outros moldes, a despeito de todo o desenvolvimento tecnológico.

\footnotetext{
${ }^{102}$ Benjamin, Walter. "Pequena História da Fotografia” In: Magia e Técnica, Arte e Política, São Paulo, Ed. Brasiliense, Coleção Obras Escolhidas, vol. 1, 3. a edição, 1987 (trad: Sérgio Paulo Rouanet), p.93.

${ }^{103}$ Comunicação de Lúcia Santaella no Seminário Textos Seminais para a Fotografia no Brasil, em 05/08/2004, mesa: Walter Benjamin - sala de debates do Centro Cultural São Paulo - S.Paulo, SP.

${ }^{104}$ BENJAMIn, Walter."A obra de arte na era de sua reprodutibilidade técnica” in:Magia e Técnica, Arte e Política, São Paulo, Ed. Brasiliense, Coleção Obras Escolhidas, vol. 1, 3. a edição, 1987 (trad: Sérgio Paulo Rouanet), p.168

${ }^{105}$ FAVILLA, André. O signo híbrido: breves impressões em relação à síntese entre a informação fotográfica e a digital, s/d. acessado em 25/06/2003, [http://wawrwt.iar.unicamp.br/].
} 
O processo de recodificação nos moldes "foto da foto", como foi realizado em AutoObjeto, assume conotações distintas do processo de recodificação por escaneamento digital da fotografia agora realizado. Em Auto-Objeto, a recodificação ótica promoveu uma iconização do conjunto de auto-retratos componentes dos painéis. Na recodificação digital das imagens para Auto-Retrato por Metro Quadrado (e por extensão Auto-Retr_Ato_Coletivo, Cabeça Defronte e AlterEgo), o caráter indicial das imagens não se perde, mas torna-se um objeto ambíguo para a percepção.

A fotografia digitalizada não se descola da própria fotografia de origem. Constituída como objeto do mundo, existente no real em sua corporeidade física - papel, emulsão, grão, matéria, peso, densidade e textura - a foto de origem torna-se o referente, portanto, o objeto dinâmico dessa "síntese entre a informação fotográfica e a digital"106 em que se constitui a fotografia digitalizada. Nessa operação de recodificação, surge uma "coexistência entre informação fotográfica e digital" cujo resultado revela "um terceiro em relação à imagem fotográfica e ao referente" ${ }^{, 107}$, contribuindo para uma nova percepção com as características que lhe são próprias. Segundo Arlindo Machado, a digitalização de uma imagem fotográfica coloca em xeque a natureza da própria imagem, criando a percepção da noção de fake pictures, ou seja, de "fotografias falsas", "modificadas" ou "falsificadas" por procedimentos de tratamento digital. Com o advento das técnicas de intervenção digital na imagem, o conceito de veracidade da Fotografia entra definitivamente em colapso e, como nota o autor, passa a ser encarada tal como de fato é, “um sistema de signos, uma 'linguagem' com a qual se pode 'escrever' verdades e mentiras, como em qualquer outro código significante" ${ }^{\text {,108 }}$. Essa

\footnotetext{
${ }^{106}$ FAVILLA, André. O signo híbrido: breves impressões em relação à síntese entre a informação fotográfica e a digital, s/d. acessado em 25/06/2003, [http://wawrwt.iar.unicamp.br/].

${ }^{107}$ FAVILLA, André. O signo híbrido: breves impressões em relação à síntese entre a informação fotográfica e a digital, s/d. acessado em 25/06/2003, [http://wawrwt.iar.unicamp.br/].

${ }^{108}$ MACHADO, Arlindo. Máquina e Imaginário: o desafio das poéticas tecnológicas, São Paulo, Edusp, $1^{\mathrm{a}} / 2^{\mathrm{a}}$ edição1993/1996, p.54
} 
é uma das tendências também apontada por Tadeu Chiarelli na produção artística fotográfica com as novas tecnologias, que consiste na intenção de "registrar a existência da fotografia no mundo" 109 , no sentido de perceber seus usos e funções, como se a fotografia repensasse a si mesma, explicitando sua própria perda de identidade e de credibilidade com o advento de novos meios tecnológicos de produção da imagem.

Nessa perspectiva, a noção de fake pictures comentada por Arlindo Machado ${ }^{110}$, coadunando com a posição de Chiarelli sobre esse momento de crise da fotografia, revela-se um fator importante para uma compreensão em conjunto das colagens digitalizadas da série Auto-Retrato Coletivo, como elemento potencializador das dubiedades da construção identitária impressa em suas imagens. No âmbito da interpretação, numa cumplicidade entre obra e espectador, essa percepção desvela a possibilidade de falseamento e manipulação das realidades ali representadas, reiterando a sua condição de simulacro. O que realmente muda nesta nova condição é que o discurso autoral organizado nas colagens enquanto crítica à construção identitária também é englobado por essa noção de simulacro, colocando numa perspectiva dialógica o ponto de vista do próprio artista como condição inicial para a participação do espectador.

Nesse sentido, a recodificação assume grande importância para este ensaio. Se de um lado, o processo de reprodutibilidade digital permite ampliar as imagens em tamanho e quantidade, potencializando o pathos das manchetes, de outro, a noção de fake pictures reforça uma identificação irônica ${ }^{111}$ que garante uma atividade estética autônoma por parte do receptor e promove um distanciamento para uma reflexão crítica.

\footnotetext{
${ }^{109}$ CHIARELLI, Tadeu. Identidade/não identidade - sobre a fotografia brasileira hoje. Catálogo exposição, 1997.

${ }^{110}$ MACHADO, Arlindo. Máquina e Imaginário: o desafio das poéticas tecnológicas, São Paulo, Edusp, $1^{\mathrm{a}} / 2^{\mathrm{a}}$ edição1993/1996, p.54

${ }^{111}$ JaUSS, Hans Robert. Pour une Esthétique de la Réception. Paris, Gallimard, 1978, p.153
} 
Dispostas numa área de um metro quadrado, numa altura adequada para envolver o campo de visão, coladas diretamente na parede, as imagens formam um conjunto que causa a sensação de uma abertura de vidro através da qual se pode observar o outro lado, como numa sala de reconhecimento. O receptor, aproximando-se, movimentando-se para ver e ler, refletese nas regiões escuras da imagem, capturado na superfície laminada como um Spectrum, aqui compreendido como sinônimo de "simulacro" na acepção de Roland Barthes, para quem esse vocábulo "garde à travers sa racine un rapport au 'spectacle' et y ajoute cette chose un peu terrible qu'il y a dans toute photographie: le retour du mort" ${ }^{\prime 12}$ no olhar do observador.

Refletindo sobre a noção de fake pictures à luz da noção de "signo híbrido"113 entre informação fotográfica e digital, considero que a digitalização conferiu às imagens resultantes um estatuto de simulacro híbrido entre a segunda e terceira categorias mencionadas por Baudrillard $^{114}$, de estatuto industrial e cibernético respectivamente. Paradoxalmente, o encontro do espectador com seu vulto refletido nas imagens promove, por sua vez, o regresso "às zonas de um exercício estético primário"115. A transformação anamórfica da imagem do indivíduo remete à noção do reflexo como simulacro de primeira categoria, de estatuto teatral, "baseado na imagem, na imitação e no fingimento" $" 116$. Por essa via, as diferentes categorias de simulacro se entrecruzam, confrontam-se e se refletem mutuamente.

\footnotetext{
${ }^{112}$ BARTHES, Roland. La Chambre Claire: note sur la photographie. Cahiers du Cinéma, Éditions de l’Étoile, Gallimard, Le Seuil, 1980, p.23. Segue tradução: esse vocábulo "guarda através de sua raiz uma relação com o 'espetáculo' e soma a ela esta coisa um tanto terrível que há em toda fotografia: o retorno do morto". (t.a.)

${ }^{113}$ FAVILLA, André. O signo híbrido: breves impressões em relação à síntese entre a informação fotográfica e a digital, s/d. acessado em 25/06/2003, [http://wawrwt.iar.unicamp.br/].

${ }^{114}$ BAUdrillard, Jean. Simulacros e Simulação.Lisboa, Relógio d'Água, 1991, pp.151-158

${ }^{115}$ BARILLI, Renato. Curso de Estética, Lisboa, editorial Estampa, 1992 p.126

${ }^{116}$ BAUdriLlard, Jean. Simulacros e Simulação.Lisboa, Relógio d’Água, 1991, p.151
} 
Nesse sentido, é possível reconhecer o simulacro de estatuto teatral entre os impulsos fundamentais da prática lúdica ${ }^{117}$, propostos por Caillois: o impulso mimicry no qual tem lugar a simulação de uma realidade outra. Relacionado ao binômio eu/outro, esse impulso baseia-se no prazer (ou desprazer) mimético "d'être autre ou de se faire passer pour un autre" ${ }^{\prime 18}$. Em Auto-Retrato por Metro Quadrado, esse impulso é despertado através dos reflexos anamórficos, na medida em que "le simulacre est transféré [...] aux spectateurs"119. Ao se perceber como um spectrum, o espectador tem a prerrogativa de prosseguir ou não no jogo de se inserir nas regiões refletoras, posto que, no dizer de Caillois, a imitação em si não é ainda simulacro, mas o torna possível e faz nascer a idéia, o gosto pela mímica ${ }^{120}$. Nesse sentido, tendo em vista que a identificação se efetiva ironicamente na obra, o espectador é, portanto, colocado numa ambivalência de vontades contraditórias, entre evitar a visão do Spectrum ou enfrentá-lo. Assim, instaura-se um diálogo conflituoso não apenas entre o espectador e a obra, mas também entre o espectador e o simulacro espectral de si mesmo, no contexto da construção da identidade coletiva.

Em suma, pela mobilização do impulso mimicry na conjunção com a performance realizada pelo espectador, Auto-Retrato por Metro Quadrado e Especulares \#7 convidam o espectador a "jogos de simulacro", no sentido de capturar suas réplicas faciais e gestuais aqui

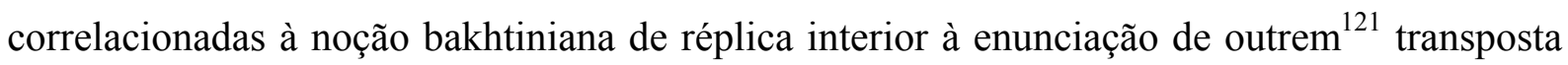
para o contexto ideológico da construção social da identidade. Assim, à apropriação da obra

\footnotetext{
${ }^{117}$ Esta reflexão que desenvolvo tem como premissa a relação estabelecida por Tavares entre as práticas lúdicas examinadas por Caillois e a Poética do Jogo inerente às obras de participação mediada corporalmente. In: Tavares, Monica. A Recepção no Contexto das Poéticas Interativas, tese de doutorado, São Paulo, ECA/USP, 2000, p.84.

${ }^{118}$ CAILloIs, Roger. Les Jeux et les Hommes: Le masque et le vertige. Paris, Gallimard, 1958, p.64. Segue tradução: "de ser outro ou de se fazer passar por um outro" (t.a.)

${ }^{119}$ CAILlois, Roger. Les Jeux et les Hommes: Le masque et le vertige. Paris, Gallimard, 1958, p.65. Segue tradução: "o simulacro é transferido [...] aos espectadores" (t.a.)

${ }^{120}$ CAILlois, Roger. Les Jeux et les Hommes: Le masque et le vertige. Paris, Gallimard, 1958, p.63

${ }^{121}$ BAKhtin, Mikhail. Marxismo e Filosofia da Linguagem. São Paulo, Hucitec, 6 a edição, 1992, p.148
} 
pelo espectador, como um texto ideológico citado, corresponde uma apreciação interna a se manifestar exteriormente pela expressão facial que, mediante o efeito especular, contribui para a constituição de um jogo dialógico de simulacros.

\section{2 - AUTO-RETR_ATO_COLETIVO: INVERSÃO DO DISCURSO IDEOLÓGICO}

Auto-Retr_Ato_Coletivo (fig.ATR-01) foi apresentado no SESC-POMPÉIA/São Paulo na exposição Uma Viagem de 450 Anos de janeiro a abril de 2004, que posteriormente se transformou num projeto itinerante por outros pontos da cidade, reagrupando os 450 artistas expositores em diferentes núcleos culturais.

A obra foi concebida especialmente para o evento no contexto emocional bem particular das festividades comemorativas aos 450 anos da cidade de São Paulo. A proposta era, a partir de uma mala de viagem de madeira, produzir um objeto artístico dentro das dimensões-limite da própria mala, em homenagem à cidade.

Aceitei o convite consciente dos riscos do desafio que empreendia, e o fiz sobretudo por haver no conceito do evento uma tônica de diversidade cultural — tendendo para uma proposta democrática — que me propiciaria estabelecer um contraponto às apologias punctuais da mídia naquele momento e inserir minha obra de um ponto de vista crítico, numa perspectiva socialmente problematizadora. 


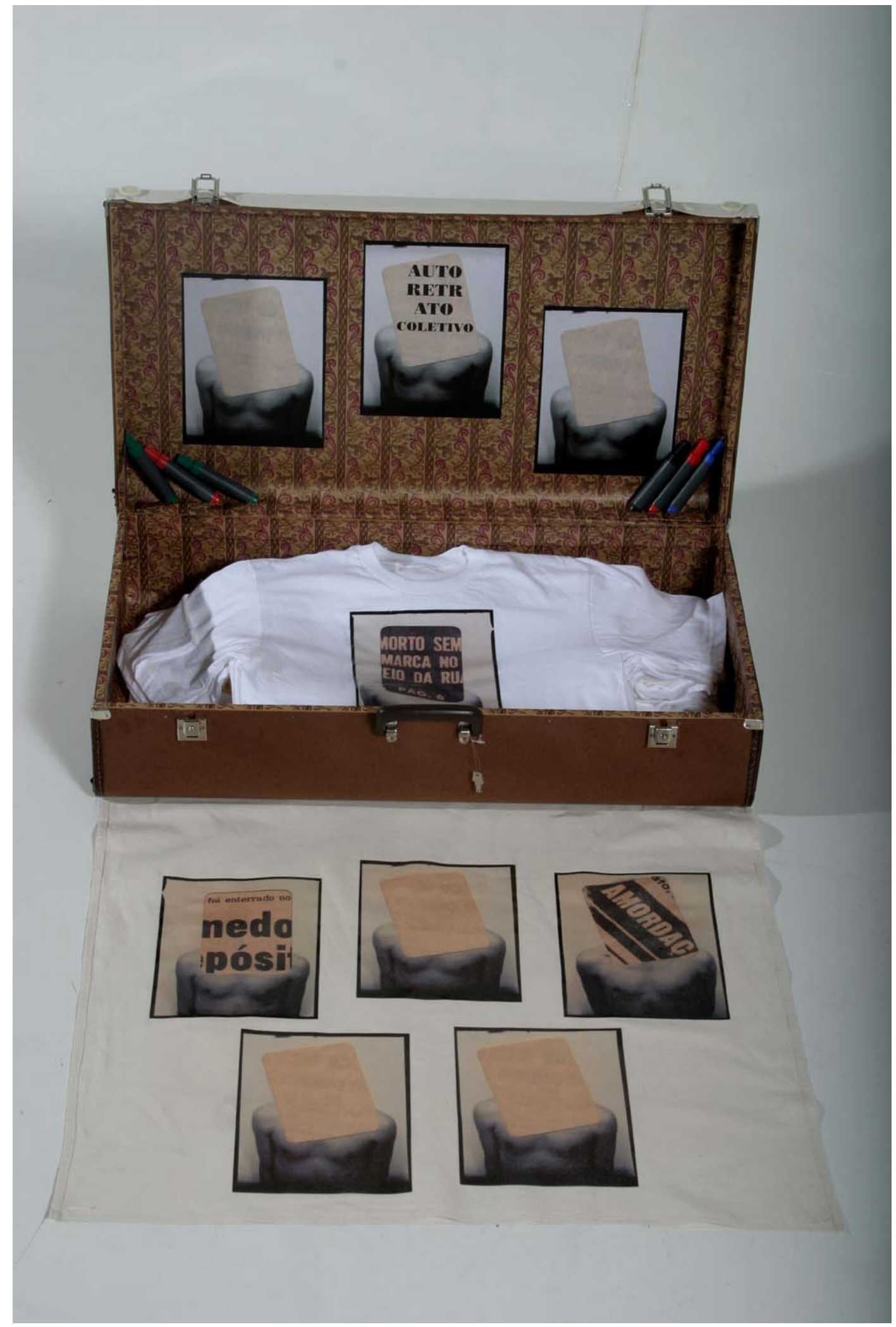

foto divulgação: Gal Oppido

FIG. ATR-01 - Auto-Retr_Ato_Coletivo, 2004 - Nardo Germano: obra manipulável. Exposição Uma Viagem de 450 Anos - SESC POMPÉIA, São Paulo, 2004. 
Procedi à impressão das imagens fotográficas digitalizadas sobre camisetas brancas, através de transferência térmica. Tal procedimento revela uma significativa troca de suporte da obra, que ao invés de estar sobre um papel, emoldurada ou adesivada diretamente numa parede, agora busca uma aproximação maior com o próprio espectador: a obra anseia o contato, ser vestida por ele. Esse desejo da obra revela a perplexidade diante das manifestações de paz nas avenidas, nas quais os manifestantes, vestidos com camisetas brancas, estampam ao peito o rosto de familiares e amigos vitimados pela criminalidade e pela violência.

Em Auto-Retr_Ato_Coletivo opto por investir em diferentes procedimentos que estabeleçam um canal de diálogo com os visitantes e deflagrem sua participação. O título da obra, em si, já traz consigo um "aceno" à participação do espectador, ao destacar da palavra "retrato" o vocábulo "ato", num convite verbal a um metafórico "ato coletivo" que, mediado corporalmente, viabiliza-se entre as possibilidades da manipulação das peças e dos atos metafóricos de experimentar e vestir as camisetas. Estrategicamente, optei por uma possibilidade suplementar para inscrição nas camisetas e na capa da mala, incluindo alguns pincéis atômicos.

Para a manipulação das camisetas, o procedimento empregado foi mais sutil, porém psicologicamente instigante. Particularmente o menciono como "ocultar para mostrar"; ou seja, a disposição das peças no interior da mala impede a imediatez da visão totalizadora do conjunto, dependendo da participação do espectador para ser fruída em sua totalidade — após a contemplação da primeira camiseta e vencida alguma primeira resistência ou inibição, inicia-se a manipulação... que é o estopim para deflagrar o experimentar e o vestir. 
A estratégia aqui consistiu em estabelecer essa dupla via de exequibilidade da obra, uma vez que uma experimentação de participação, ao se inserir no social, é submetida às leis de um sistema que, não raro, é alheio às aspirações do artista, ou submetida a situações que inviabilizam seu projeto. Neste caso, considerado o perfil curatorial da exposição, que envolvia um espaço cenográfico de grandes dimensões no qual foram alojadas as obras de 450 artistas, havia o risco de as inscrições se alastrarem sobre as outras obras, que não previam esse tipo de abertura ao espectador. A organização do evento optou por não colocar os pincéis, inviabilizando a participação através de inscrições.

A obra concretizou então a sua vocação de abertura à participação pela via do "ocultar para mostrar" que convida à manipulação. Ao aproximar-se, o visitante vê a mala aberta, colocada sobre um apoio que a dispõe relativamente à altura de sua mão e, ao primeiro olhar, tem acesso visual ao seu conteúdo: um conjunto de 25 camisetas brancas arranjadas, cuidadosamente, uma sobre a outra, só lhe permitindo contemplar a imagem impressa na camiseta que está por cima das demais. Situação instauradora de curiosidades, dúvidas, receios: curiosidade de ver as outras imagens impressas, dúvidas quanto a haver ou não imagens impressas nas camisetas colocadas embaixo, receios de não ser permitido tocar na obra...

A participação mediada corporalmente começa a se desenrolar a partir dos primeiros movimentos de aproximação do espectador e de seu gesto de erguer uma ponta da camiseta, espiar e constatar que a camiseta de baixo também possui uma imagem estampada, e também a outra e outra. Uma subjetividade formante revela-se na gestualidade do espectador que deflagra uma fruição em movimentos que lhe são exclusivos, seja através do folheamento 
sistemático, cuidadoso, ou através do desdobramento desordenado das camisetas dentro da mala, ou mesmo da retirada das peças e do modo como as recoloca onde estavam.

Cada espectador tem uma fruição única e irrepetível da obra. Cada vez que a executa, a obra lhe toma de empréstimo sua gestualidade para formar-se, algo que está nele naquele preciso momento, seu modo de ser, seu estado de espírito, seu ponto de vista. No contexto comemorativo da exposição, cria-se uma questão para o espectador, pois a obra, ao invés de surgir no espírito da comemoração (da festa institucionalizada) em que o espectador comparece à exposição, ela surge no contraponto desse momento festivo geral — e instaura um momento de contemplação e reflexão crítica.

Vale lembrar o "caráter pessoal, e portanto expressivo e formativo do operar humano" presente nos atos de interpretação e contemplação diante da obra de arte:

\begin{abstract}
"O operar humano se caracteriza pelo fato de ser sempre algo pessoal. Com base neste princípio, toda atividade da pessoa, que se esgote em um ato singular e isolado e não destinado a ulterior desenvolvimento, quer se constitua em um operar contínuo, cujos atos singulares tendem todos a um fim preciso a alcançar, é sempre atividade de uma pessoa, bem determinada em sua definição, irrepetível em sua singularidade e no entanto infinitamente aberta a possibilidades que ela mesma vai descobrir."122
\end{abstract}

Nesse sentido, na relação obra/receptor, a obra não é executada a partir do estado emocional com que o espectador chega a ela e, sim, de uma resultante desse estado com o efeito que a obra provoca sobre seu espírito. Desse confronto, resulta uma gestualidade que expressa algo que o artista não tem como prever e que até mesmo o espectador, que é uma pessoa "bem determinada em sua definição", vai ele mesmo descobrir na relação dialógica estabelecida com a obra.

\footnotetext{
${ }^{122}$ Pareyson, Luigi. Estética - Teoria da Formatividade. Rio de Janeiro, Petrópolis, ed. Vozes, 1993. (trad. Ephraim Ferreira Alves), 1992, CapV - p.176
} 
Por outro lado, à medida em que as gestualidades todas vão gradual e cumulativamente se sucedendo, aquela ordem inicial das peças é desfeita. O protagonismo da camiseta que, sobre as outras, tinha sua estampa exposta, passa a ser experimentado por outras camisetas, por conta do acaso ou do movimento permutatório (consciente ou não) entre os receptores, que invertem a ordem em que estão dispostas. Com a alteração constante da disposição das peças, a organização inicial se desfaz e culmina em desordem, quando então a obra se apresenta aos espectadores com as peças totalmente reviradas — indício claro para os próximos visitantes de que se trata de uma obra manipulável. Eventualmente, um outro espectador, ao re-executar a obra, pode reordená-la ao seu próprio modo, definindo ele próprio a forma como a obra vai se apresentar ao público a partir de então. Nesse sentido, a obra transita em sua proposição participativa, entre as tendências antagônicas do binômio ludus/paidia ${ }^{123}$, em fluxos de ordem e desordem das camisetas dentro da mala de viagem.

A recepção da obra configura-se numa performance resultante de uma sinergia totalizadora, conjugando a materialidade da obra (e neste caso trata-se da maleabilidade do tecido das camisetas) à singularidade gestual do receptor. A performance que se desenrola na recepção de Auto-Retr_Ato_Coletivo envolve essa gestualidade que se revela no modo como as pessoas desdobram as camisetas no ar, no movimento dos braços estendidos voltados ora para si, ora para seus acompanhantes quando as apóiam sobre o peito girando o torso na direção dos outros para exibirem a estampa sobre si mesmas. Da mesma forma envolve uma expressão corporal, quando algumas pessoas mais despojadas vestem a camiseta e a exibem (tendo a si mesmas como suporte da obra) e fingem se locomover, peito para fora (numa avenida, numa passeata pela paz? - afirmar o significado dessa performance seria promover um julgamento monológico final e, portanto, um fechamento do dialogismo alcançado).

\footnotetext{
${ }^{123}$ TAVARes, Monica. A Recepção no Contexto das Poéticas Interativas. S.Paulo, SP. Tese de Doutorado ECAUSP. 2000, p77
} 
Contudo, tal atitude parece denotar uma adesão à obra a ponto de o receptor literalmente "vestir a camisa" do artista, numa "incorporação do corpo à obra e da obra ao corpo" "124 que se aproximaria do princípio fundamental mimicry:

\begin{abstract}
"Tout jeu suppose l'acceptation temporaire, sinon d'une illusion (encore que ce dernier mot ne signifie pas autre chose qu'entrée en jeu: in-lusio), du moins d'un univers clos, conventionnel et, à certains égards, fictif. Le jeu peut consister, non pas à déployer une activité ou à subir un destin dans un milieu imaginaire, mais à devenir soi-même un personnage illusoire et à se conduire en conséquence." ${ }^{125}$
\end{abstract}

Nessa condução do jogo mimético realizado, ocorre a transição do participante de uma condição de suporte para a incorporação da obra que produz um campo de transformação de sentidos, propiciando uma inversão do discurso ideológico da construção identitária. Refirome não apenas àquela construção que estava na origem das matérias jornalísticas utilizadas na colagem impressa nas camisetas, mas também àquela que estava em pleno curso no contexto da festividade. Com o tema da construção identitária aberto ao dialogismo, produz-se uma relativização daquela identidade social do povo associada à criminalidade forjada pelos aparelhos ideológicos. Ao mesmo tempo, também se relativiza aquela identidade passiva, ingênua e alienada, solicitada pelas circunstâncias imediatistas da comemoração.

\footnotetext{
${ }^{124}$ OITICICA, Hélio. Entrevista com Ivan Cardoso em: R Fluchetti: Vampirismo Rio de Janeiro, Ebal, 1990, p.86.

${ }^{125}$ CAIllois, Roger. Les Jeux et les Hommes: Le masque et le vertige. Paris, Gallimard, 1958, pp.60-61. Segue tradução: "Todo jogo supõe a aceitação temporária, senão de uma ilusão (ainda que essa última palavra não signifique outra coisa senão que entrada em jogo: in-lusio), pelo menos de um universo fechado, convencional e, de alguns pontos de vista, fictício. O jogo pode consistir não em executar uma atividade ou em submeter-se a um destino num mundo imaginário, mas em tornar-se ele mesmo um personagem ilusório e a se conduzir como tal." (t.a.)
} 


\section{3 - CABEÇA DEFRONTE: UM AMBIENTE IDENTITÁRIO}

Cabeça Defronte (fig.CBD-01 a 08) é uma instalação composta como uma imagerie de fotos digitalizadas impressas em papel auto-adesivo não-laminado, coladas diretamente sobre a parede de alvenaria. Espelhos de mão, adesivados sobre algumas das imagens, refletem o rosto do espectador, enquadrando-o em seu recorte, e também o próprio ambiente, absorvendo-os no corpo da obra. Por esses elementos, a circulação do espectador promove novas aparições do conjunto, causando variações de ponto de vista do ambiente refletido. A instalação, explorando artisticamente o espaço e as marcas da parede de alvenaria no contexto da identidade coletiva em discussão, constitui um "recinto-obra", nos termos de Hélio Oiticica, "aberto à participação, cujos significados são acrescentados pela participação

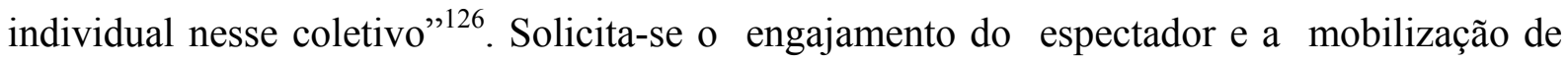
suas capacidades e faculdades contemplativas, perceptivas e locomotoras ${ }^{127}$ ligadas à noção de environment, "conçu comme une proposition spatiale autonome invitant le spectateur à établir un paradigme critique, esthétique ou idéologique, et ne constituant pas le simple reflet d'un contexte sócio-historique" ${ }^{\text {128 }}$. Configura-se estruturalmente um ambiente artístico "sous la forme d'une proposition symbolique ou métaphysique", que convida o espectador "à donner une réponse totale, cést-à-dire à la fois intellectuelle et physique" no exercício de "une activité polysensorielle spontanée"129 que se constitui numa outra variação de pontos de vista.

\footnotetext{
${ }^{126}$ OiticicA, Hélio. Aspiro ao Grande Labirinto, Rio de Janeiro, Rocco, 1986, p.119 (coletânea de textos de HO escritos entre 1954-1969)

${ }^{127}$ PoPPER, Frank. Art, Action et Participation: l'artiste et la creativité aujourd'hui, Paris, éditions Klincsteck, 1980, p11-14

${ }^{128}$ Popper, Frank. Art, Action et Participation: l'artiste et la créativité aujourd'hui. Paris, éditions Klincsteck, 1980, p.12. Segue tradução: "concebido como uma proposição espacial autônoma convidando o espectador a estabelecer um paradigma crítico, estético ou ideológico, e não constituindo o simples reflexo de um contexto sócio-histórico" (t.a.)

${ }^{129}$ POPPER, Frank. Art, Action et Participation: l'artiste et la créativité aujourd'hui. Paris, éditions Klincsteck, 1980, p.12. Segue tradução: "sob a forma de uma proposição simbólica ou metafísica", que convida o espectador "a dar uma resposta total, quer dizer, ao mesmo tempo intelectual e física" no exercício de "uma atividade polisensorial espontânea" (t.a.)
} 


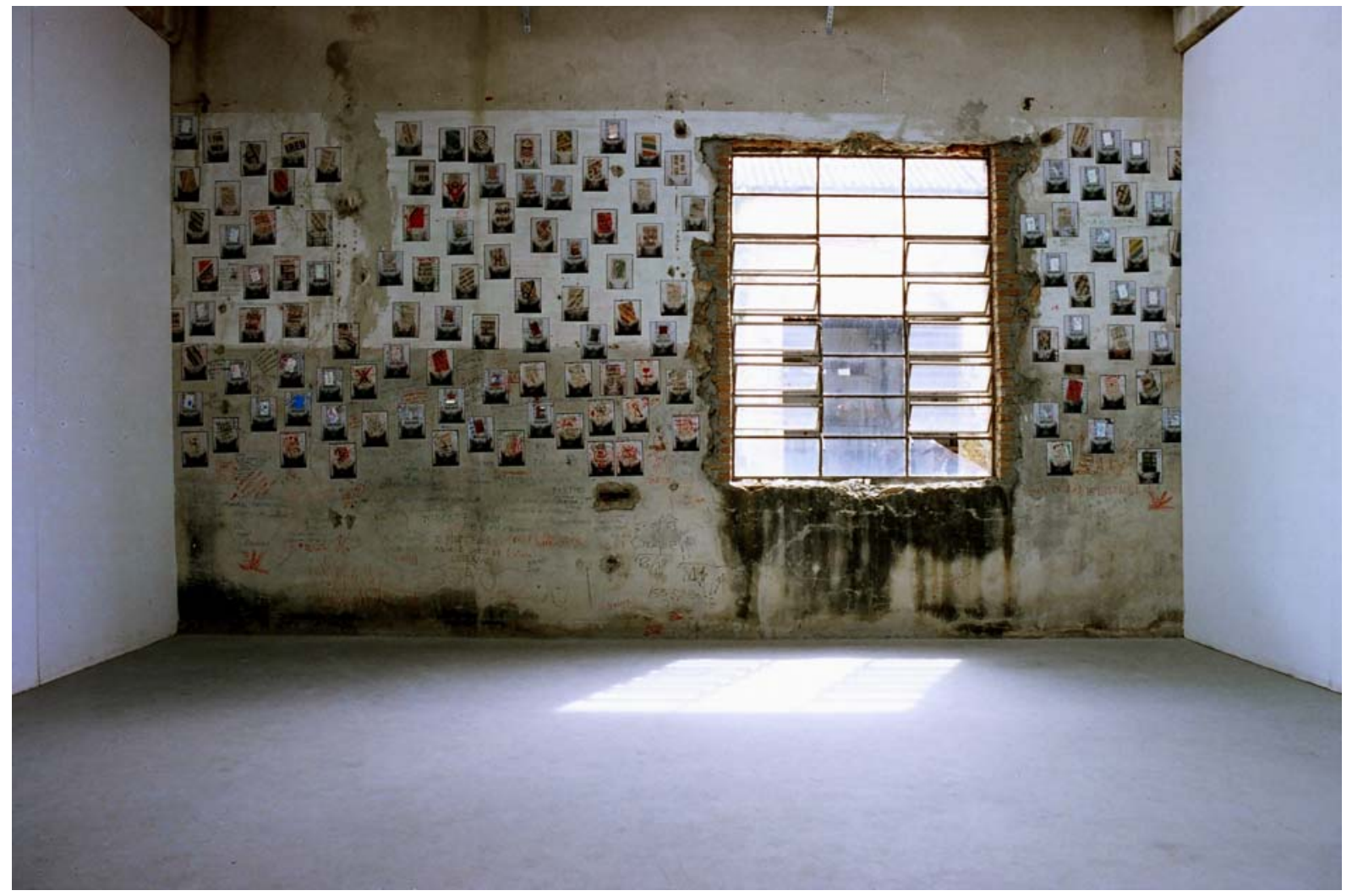

FIG. CBD-01 - Instalação Participativa Cabeça-Defronte, 2003 - Nardo Germano: ambiente identitário. Exposição Arte do Novo Século, Complexo Argos, Jundiaí, São Paulo, 2003. 


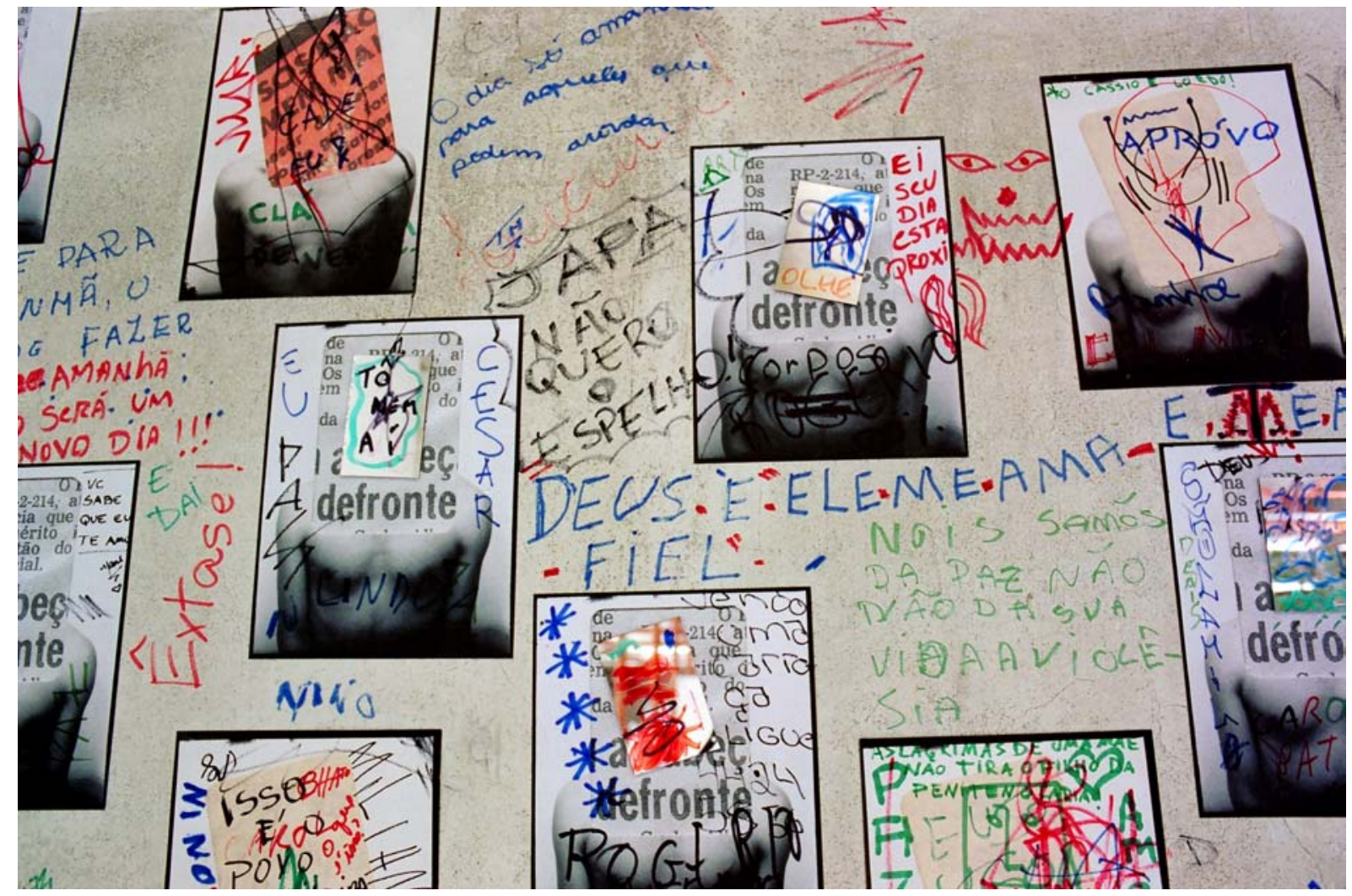

FIG. CBD-02 - Instalação Participativa Cabeça-Defronte, 2003 (detalhe) - Nardo Germano: intervenções dos participantes. Exposição Arte do Novo Século, Complexo Argos, Jundiaí, São Paulo, 2003 

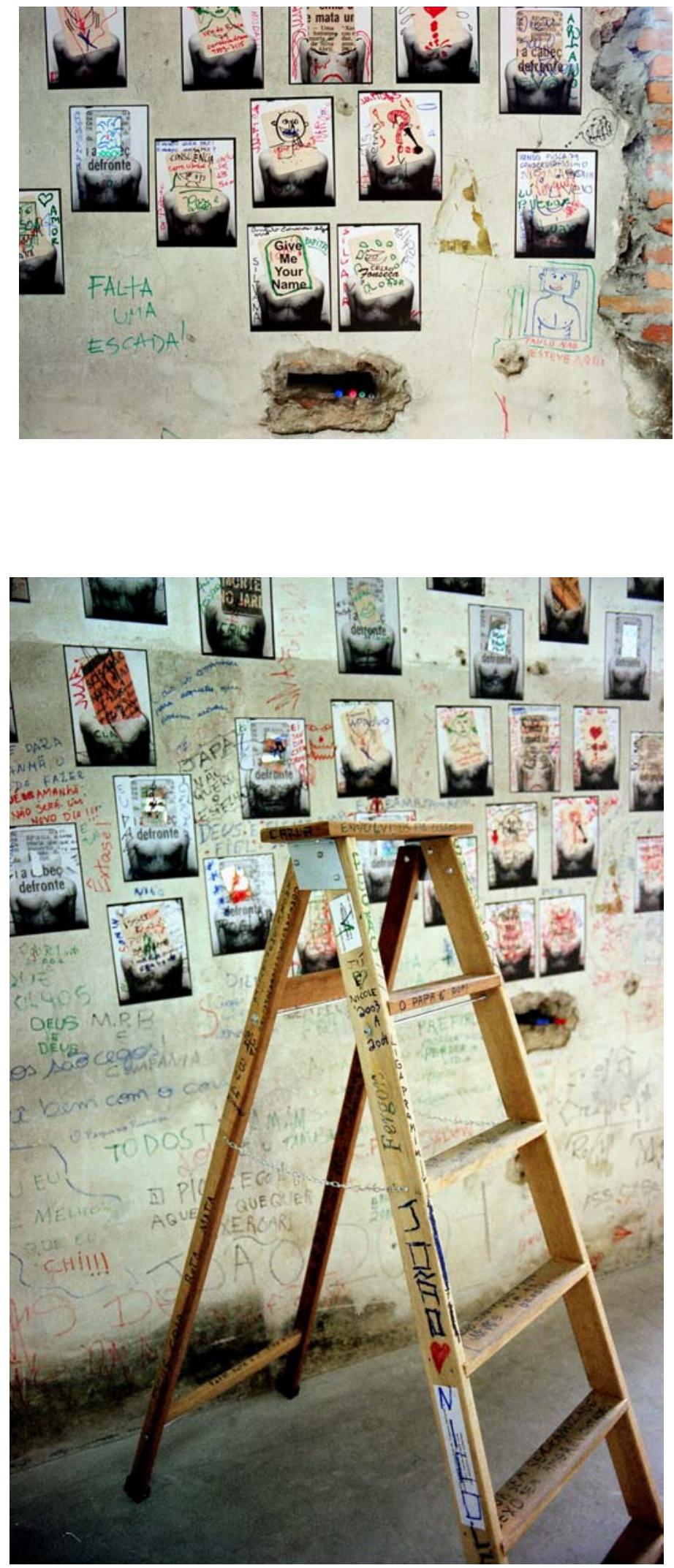

FIG. CBD-03 e 04 - Instalação Participativa Cabeça-Defronte, 2003 (detalhe) - Nardo Germano: diálogo entre participante e autor, mediados pela obra.

Exposição Arte do Novo Século, Complexo Argos, Jundiaí, SP, 2003 


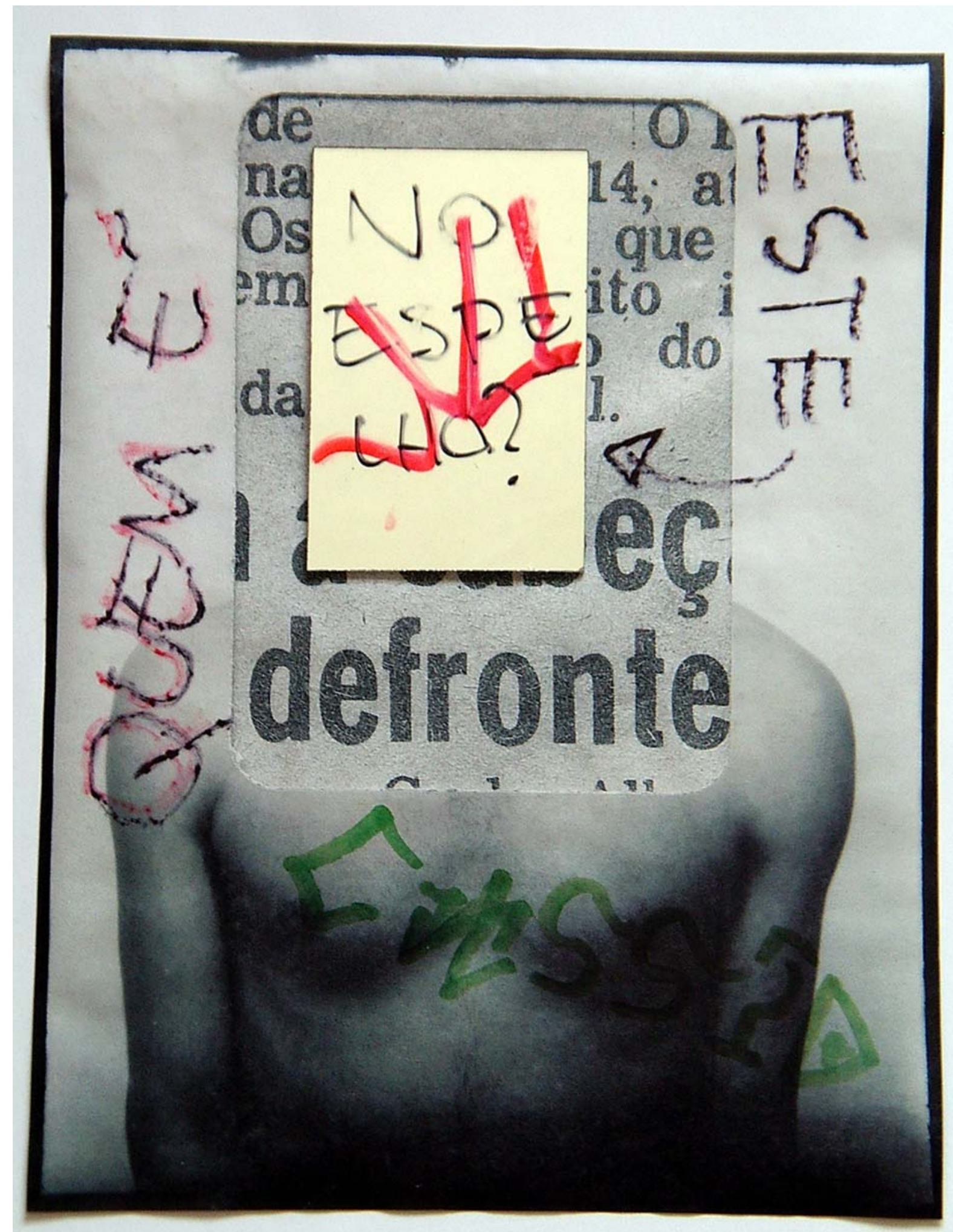

FIG. CBD-05 - Instalação Participativa Cabeça-Defronte, 2003 (detalhe: espelho) - Nardo Germano. Exposição Arte do Novo Século, Complexo Argos, Jundiaí, SP, 2003. 


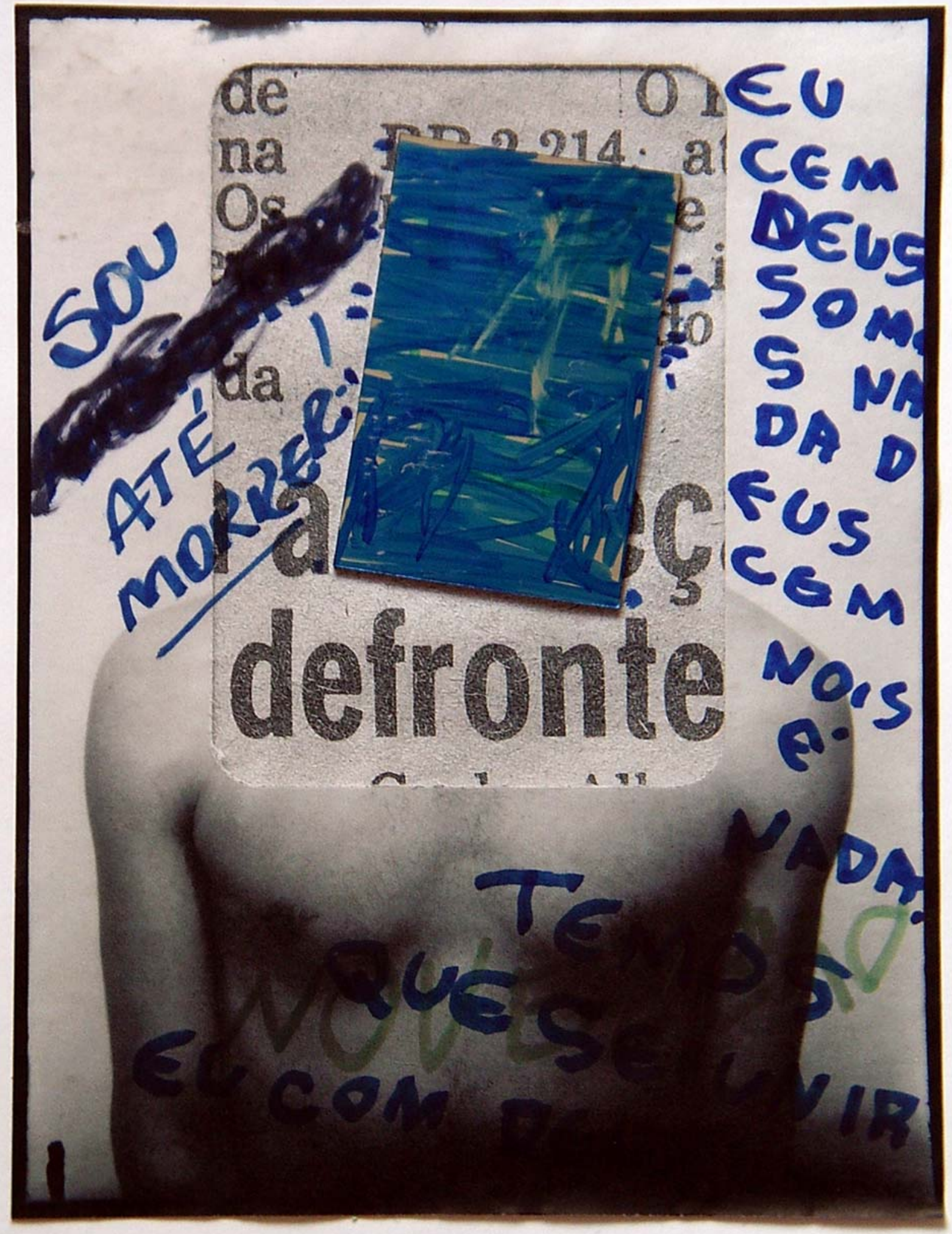

FIG. CBD-06 - Instalação Participativa Cabeça-Defronte, 2003 (detalhe: espelho) - Nardo Germano. Exposição Arte do Novo Século, Complexo Argos, Jundiaí, SP, 2003. 
FIG. CBD-07 - Instalação Participativa Cabeça-Defronte, 2003 (detalhe) - Nardo Germano. Exposição Arte do Novo Século, Complexo Argos, Jundiaí, SP, 2003. 
FIG. CBD-08 - Instalação Participativa Cabeça-Defronte, 2003 (detalhe) - Nardo Germano. Exposição Arte do Novo Século, Complexo Argos, Jundiaí, SP, 2003. 
FIG. CBD-09 - Instalação Participativa Cabeça-Defronte, 2003 (detalhe) - Nardo Germano. Exposição Arte do Novo Século, Complexo Argos, Jundiaí, SP, 2003. 
No caso de Cabeça Defronte, a noção de performance é mais flagrante e nítida na relação do espectador com a obra. Aos deslocamentos, às escolhas (de cor, imagem sobre a qual fazer a inscrição) e à ação propriamente dita, somam-se as relações interpessoais intensificadas pela situação instaurada, fato mais evidente no dia da abertura, mas também observado durante o período de exposição: a disputa pelos pincéis; solicitação de licença para acessar a área desejada; negociação entre os participantes com a permuta de pincéis e inclusive a própria comunicação estabelecida para troca de comentários sobre as inscrições já realizadas. Cabe salientar que se estabeleceu inclusive comunicação com o próprio artista por meio da inscrição "Falta uma escada": Receptor trocando seu papel para emissor em relação ao artista, este agora receptor da mensagem numa inversão de papéis, numa situação que culmina com a inserção de uma escada no espaço expositivo (figs.CBD-03 e 04). Essa resposta à inscrição corresponde à efetivação de um diálogo mediado pelo próprio ambiente da obra, enquanto "lieu de rencontre priviligié des faits physiques et psychologiques qui animent notre univers" 130 - universo tanto do espectador quanto, do meu ponto de vista, do artista-também-participante.

Cabe salientar que a presença da escada não somente ampliou a dimensão daquela performance mencionada, como também se tornou ela própria objeto de inscrições do espectador (fig.CBD-04). Com relação às inscrições, o efeito da proposta de participação sobre os receptores foi enormemente bem recebido, sobretudo pelo fato de essa abertura não ter sido proposta no sentido de escrever opiniões a respeito da obra, como acontece num livro de visitação. No embate direto com a obra, como suporte para as inscrições, a participação do público revelou tomadas de posição em relação aos temas envolvidos, como identidade, vida e morte, violência, religiosidade, relações sociais, ideologia etc. No caso desta obra, a proposta

\footnotetext{
${ }^{130}$ PopPer, Frank. Art, Action et Participation: l'artiste et la créativité aujourd'hui. Paris, éditions Klincsteck, 1980, p.11. Segue tradução: "local de encontro privilegiado dos fatos físicos e psicológicos que animam nosso universo" (t.a.)
} 
de participação incorpora os elementos heteróclitos trazidos pelo espectador ao campo das imagens e ao ambiente identitário constituído pela instalação - artísticos ou não.

Nos auto-retratos de Cabeça Defronte, reconhece-se a idéia de performance "como indicador daquela prestação largamente inter-sensorial, sin-estética, mas de base predominantemente gestual-motora" ${ }^{, 131}$ à qual os espectadores são convidados no sentido de torná-los plurais, considerando-se que "une performance est un événement physique, et comme tel un objet autographique unique; mais [...] par l'itération [elle donne occasion] à un art autographique pluriel" ${ }^{\text {132, }}$, constituindo-se assim, segundo Gèrard Genette, um fato de transcendência por imanência plural. Nesse sentido, considero como um sinal positivo da participação do público o fato de as inscrições terem se espalhado não somente pelas fotografias, mas também pela parede, de alto a baixo, na escada, num ritmo tal que os registros semanais que foram realizados da instalação revelam a gradativa justaposição e/ou sobreposição de textos, desenhos e símbolos, numa polifonia intertextual de "caracteres autográficos"133 em que os traços singulares e pessoais em seu conjunto e no contexto de uma performance iterativa tal como conceituada por Gérard Genette ${ }^{134}$, constituíram, com a progressão das intervenções, uma autografia plural. A diversidade de pontos de vista e de experiências de vida configuraram-se como identidades plurais em confronto, alcançando em novas dimensões a noção de "auto-retrato coletivo" de minha proposta artística original.

Na perspectiva de reconhecer na Poética do Jogo a caracterização das duas tendências antagônicas propostas por Roger Caillois, observa-se que um dos problemas fundamentais

\footnotetext{
${ }^{131}$ BARILLI, Renato. Curso de Estética, Lisboa, editorial Estampa, 1992 p.126

${ }^{132}$ GenetTe, Gérard. L'Oeuvre de l'Art: immanence et transcendence Paris, Éditions du Seuil, 1994. p.84. Segue tradução: "uma performance é um evento físico, e como tal um objeto autográfico único, mas [...] pela iteração [ela dá ocasião] a uma arte autográfica plural".

${ }^{133}$ Goodman, Nelson. Los Lenguages del Arte: aproximación a la teoria de los símbolos, Barcelona, ed. Seix Barral, S.A., 1976 (trad.: Jem Cabanes) pp.123/133.

${ }^{134}$ Genette, Gérard. L'Oeuvre de l'Art: immanence et transcendence Paris, Éditions du Seuil, 1994. p.83-84
} 
colocado ao participante do jogo estético reside no confronto com a dialética entre paidia e $l_{\text {ludus }}{ }^{135}$ em que a turbulência, a desordem e o sensível, característicos do primeiro, confrontam-se com a regra, a ordem e o inteligível, que caracterizam o segundo. Nesse sentido, um aspecto impressionante chama a atenção na experimentação dialética entre as duas tendências antagônicas que se verificou com a instalação participativa Cabeça Defronte. De um lado, os participantes reconheceram algumas regras do jogo ${ }^{136}$, como a convenção artística que concentrou a instalação naquela parede de alvenaria, tratada como elemento integrante do ambiente criado pela instalação, e não nos módulos brancos laterais ao estilo cubo branco - que permaneceram intactos até o final da exposição (fig.CBD-01). As inscrições se espalharam pelas imagens, pelos espelhos (fig.CBD-05 e 06) e nos vidros da própria janela (com a qual estabeleci um diálogo com os recortes vazados dos auto-retratos). Além disso, a instalação participativa deflagrou processos dialógicos na própria relação interpessoal dos participantes, na negociação dos instrumentos de inscrição, na ocupação dos espaços e comentários sobre as inscrições alheias, revelando-se aí também o princípio de ordem, equivalente ao ludus, na construção de um ambiente comum de vivência. Por outro lado, em total oposição àquela atitude regrada, os espectadores entregaram-se sensivelmente à turbulência e desordem na manifestação de uma fantasia incontrolada e de natureza anárquica correspondente à paidia $^{137}$, de tal modo que as inscrições extrapolaram o campo das imagens oferecido para participação, invadindo a parede e a escada no espaço da exposição, inclusive com a sobreposição de textos e desenhos.

\footnotetext{
135 TAVAres, Monica. A Recepção no Contexto das Poéticas Interativas, S.Paulo, SP. Tese de Doutorado ECAUSP. 2000, p.77

${ }^{136}$ CAILlois, Roger. Les Jeux et les Hommes: Le masque et le vertige. Paris, Gallimard, 1958, pp.75-91

${ }^{137}$ CAILlois, Roger. Les Jeux et les Hommes: Le masque et le vertige. Paris, Gallimard, 1958, p.48
} 
Despertados pela entrega dos espectadores à paidia, às "manifestations spontanées de l'instinct de jeu"138, elementos de carnavalização tomaram corpo nas inscrições sobre a obra. O conceito de carnavalização, empregado por Bakhtin $^{139}$ a partir de uma acepção ampla das festas de carnaval, “implica paródia e interação de discursos distintos, implica intertextualidade que dá origem a um volume de textos especial e dinâmico onde se somam texto-figura e texto figurado" ${ }^{140}$, numa leitura que o presente faz de elementos do passado. Pelo seu caráter libertário em confronto com o normativo bem como por sua sólida ligação da carnavalização com o jogo ${ }^{141}$, revela-se esse princípio de paidia pela manifestação de elementos associados a “imagens do 'baixo' material e corporal, obscenidades ambivalentes" ${ }^{, 142}$, ao desacato à autoridade, a imprecações, vocábulos chulos e de baixo calão ${ }^{143}$, que podem ser encontrados em várias inscrições registradas em Cabeça Defronte (figs.CBD-07 a 09).

Pela instauração dialógica promovida, o diálogo direto entre os participantes em ação e nas inscrições, as inter-relações dialógicas dos diferentes textos, os pontos de vista (os mais diversos e contraditórios) e a carnavalização correlacionaram-se na arena comum da instalação. Nesse sentido, Cabeça Defronte configurou-se no contexto da identidade coletiva da proposta da série Auto-Retrato Coletivo como um ambiente identitário polifônico. A pluralidade de pontos de vista acumulada durante o período da exposição redimensiona o discurso monológico da construção ideológica da identidade coletiva pautada no estigma da

\footnotetext{
${ }^{138}$ CAILloIs, Roger. Les Jeux et les Hommes: Le masque et le vertige. Paris, Gallimard, 1958, p.76. Segue tradução:"manifestações espontâneas do instinto de jogo" (t.a.)

${ }^{139}$ BakHtin, Mikhail. A Cultura Popular na Idade Média e no Renascimento, SP, Hucitec, $4^{\mathrm{a}}$ ed., 1999, p.189

${ }^{140}$ Ferrara, Lucrécia D’Aléssio. A Estratégia dos Signos. São Paulo, Perspectiva,1981, p.77

${ }^{141}$ BAKHTIn, Mikhail. A Cultura Popular na Idade Média e no Renascimento, SP, Hucitec, $4{ }^{\mathrm{a}}$ ed., 1999, p.201

${ }^{142}$ BAKHTIN, Mikhail. A Cultura Popular na Idade Média e no Renascimento, SP, Hucitec, $4^{\mathrm{a}}$ ed., 1999, p.240

${ }^{143}$ BAKHTIn, Mikhail. A Cultura Popular na Idade Média e no Renascimento,SP,Hucitec,4 ${ }^{\mathrm{a}}$ ed., 1999,p.323-383
} 
criminalidade e da violência, transcendendo-a pelo "extraordinário poder transfigurante"144 da percepção carnavalesca.

Nesta obra da série Auto-Retrato Coletivo, no contexto da construção de uma identidade coletiva, constituiu-se o necessário embate entre o Ideológico e o Utópico.

\section{4 - Corpo Coletivo: Performances Participativas}

A performance participativa Corpo Coletivo inaugura o núcleo de intervenções urbanas no espaço público como nova estratégia de participação do espectador na constituição da série Auto-Retrato Coletivo, no sentido de transpor a noção de coletividade tratada na obra para uma relação arte/vida. Este núcleo inscreve-se no contexto das experimentações de abertura de $2^{\circ}$ grau $^{145}$, de "participação mediada corporalmente" ${ }^{146}$, colocando a questão da identidade coletiva em discussão pública num contato direto entre artista e espectador, numa conjunção ideológica e artística com a Poética do Corpo de Lygia Clark ${ }^{147}$ e com o Programa Ambiental de Hélio Oiticica ${ }^{148}$. Até o momento, duas proposições foram realizadas:

1. Performances participativas Corpo Coletivo (figs.CRP-01/15): exposição ambulante, coleta de fotos e inscrições do público com canetas acrílicas sobre camisetas brancas vestidas no corpo do próprio artista, expressando através de textos, desenhos, símbolos etc, o seu pensamento ou sentimento sobre a identidade coletiva.

\footnotetext{
${ }^{144}$ Ferrara, Lucrécia D’Aléssio. A Estratégia dos Signos. São Paulo, Perspectiva,1981, p.77

${ }^{145}$ PlAZA, Julio. Arte e Interatividade: autor-obra-recepção, 2000, p.5 Acessado em 25/06/2003 [http://www.plural.com.br/jplaza/texto01.htm].

${ }^{146}$ Tavares, Monica. A Recepção no Contexto das Poéticas Interativas, S.Paulo, SP. Tese de Doutorado ECAUSP. 2000, p.73-74. No âmbito das poéticas da participação, Tavares distingue a participação mediada corporal, automática e instantaneamente. pp.74-101

${ }^{147}$ ClARK, Lygia.. Lygia Clark, Rio de Janeiro, edição Funarte, 1980

${ }^{148}$ OiticiCA, Hélio. Aspiro ao Grande Labirinto, Rio de Janeiro, Editora Rocco Ltda., 1986
} 


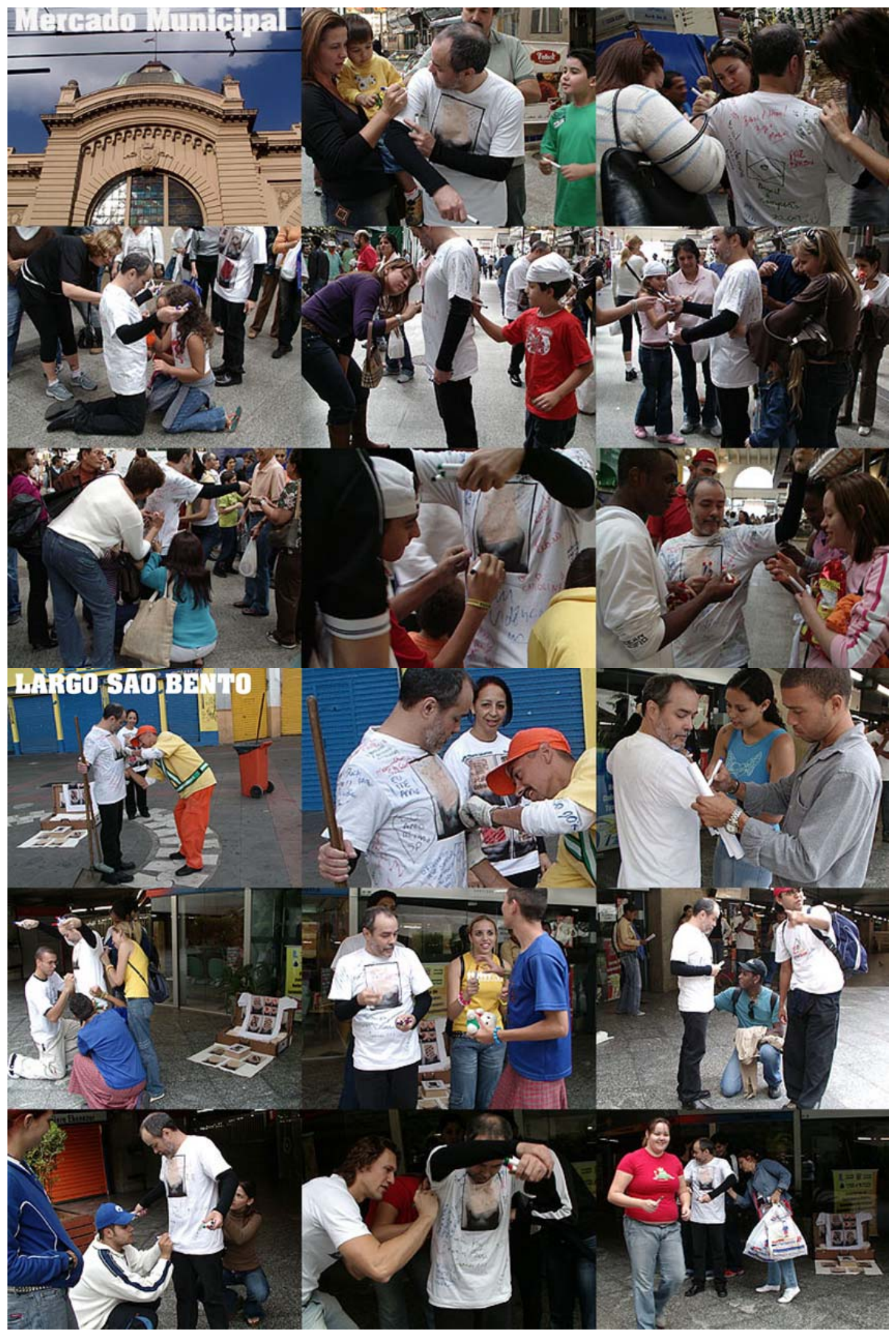

FIG. CRP-01 e 02 - Performance Participativa Corpo Coletivo, 2006 - Nardo Germano. Virada Cultural SP.2006. Mercado Municipal e Largo São Bento. http://www.nardogermano.com/autoretratocoletivo 


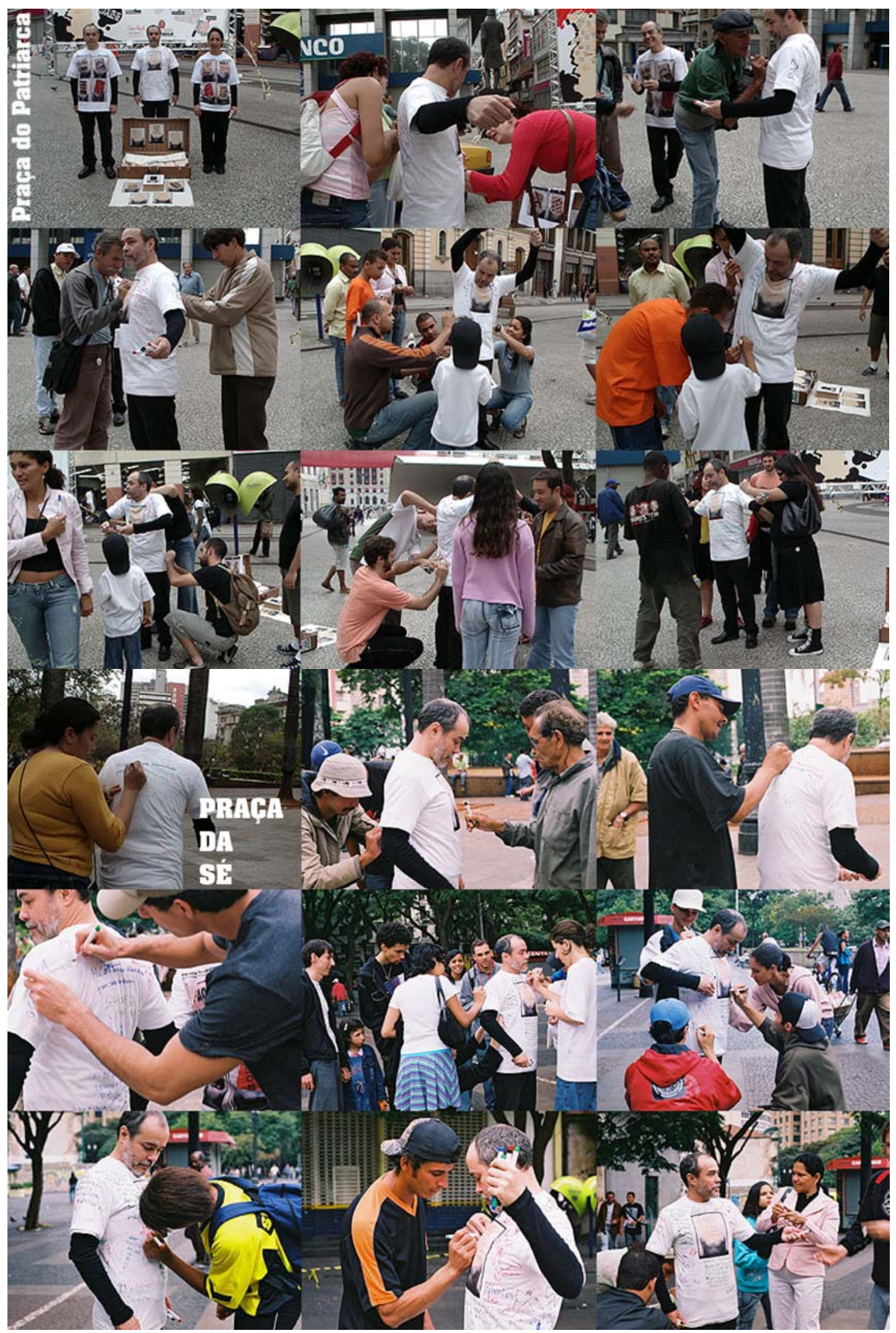

FIG. CRP-03 e 04 - Performance Participativa Corpo Coletivo, 2006 - Nardo Germano. Virada Cultural SP.2006. Praça do Patriarca e Praça da Sé. http://www.nardogermano.com/autoretratocoletivo 

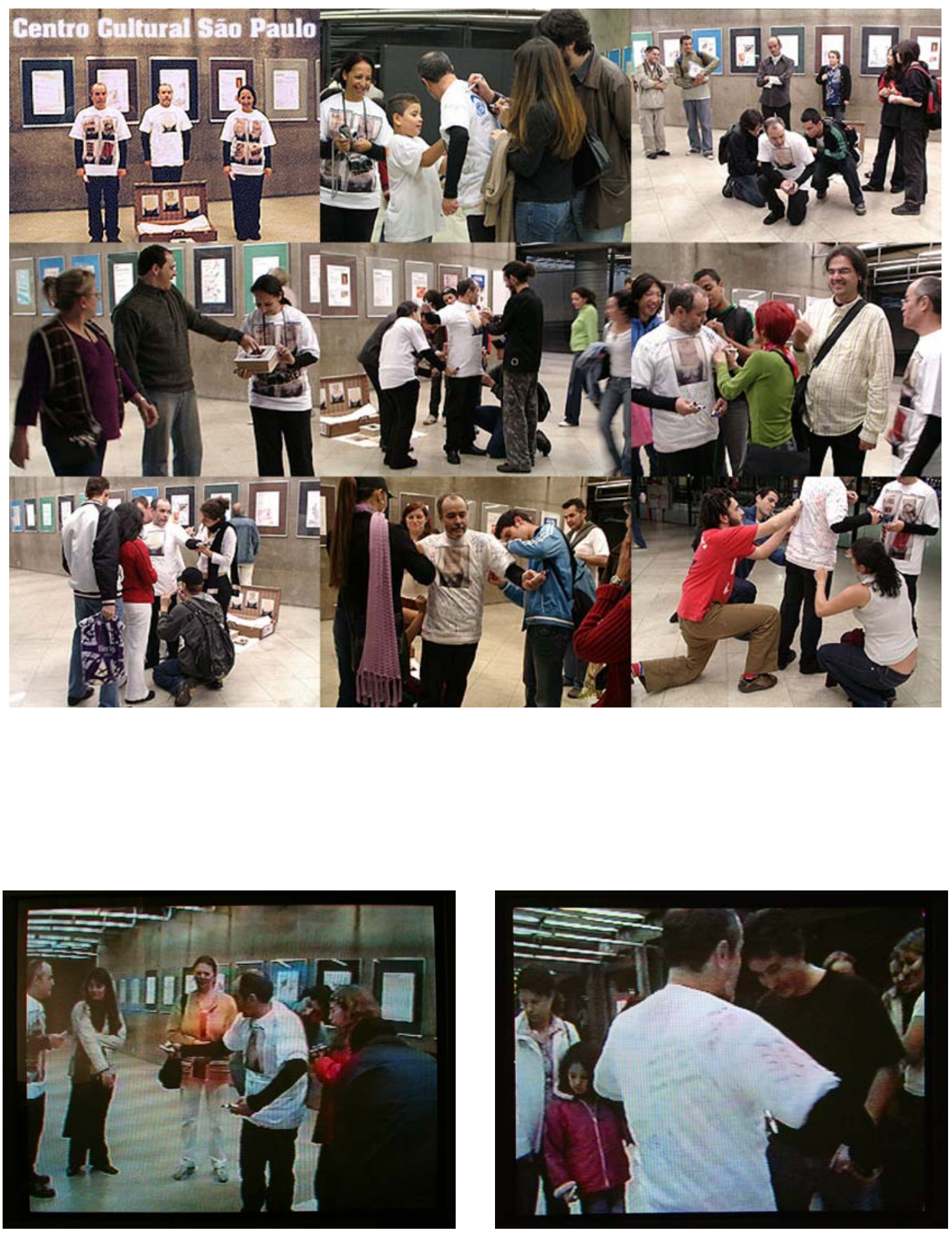

FIG. CRP-05 - Performance Participativa Corpo Coletivo, 2006 - Nardo Germano. Virada Cultural SP.2006. Centro Cultural São Paulo. http://www.nardogermano.com/autoretratocoletivo FIG. CRP- 06 e 07 - Frames de vídeo (arquivo: CCSP. Celso Toquete) 


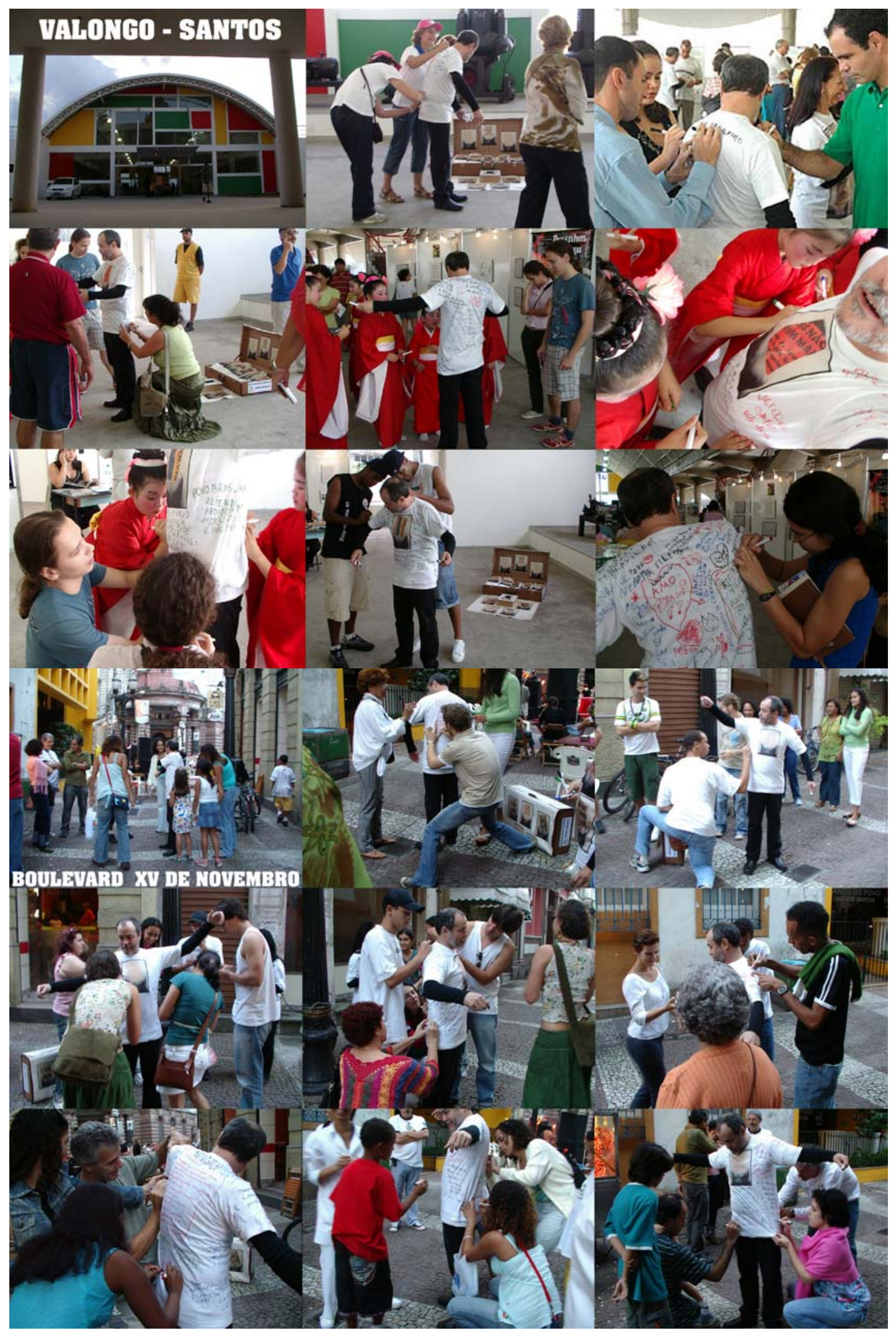

FIG. CRP-08 e 09 - Performance Participativa Corpo Coletivo, 2006 - Nardo Germano. Maratona Cultural Caros Amigos de Santos, SP, 2006. Estação Valongo e Boulevard da Rua XV de Novembro. http://www.nardogermano.com/autoretratocoletivo/corpocoletivo 


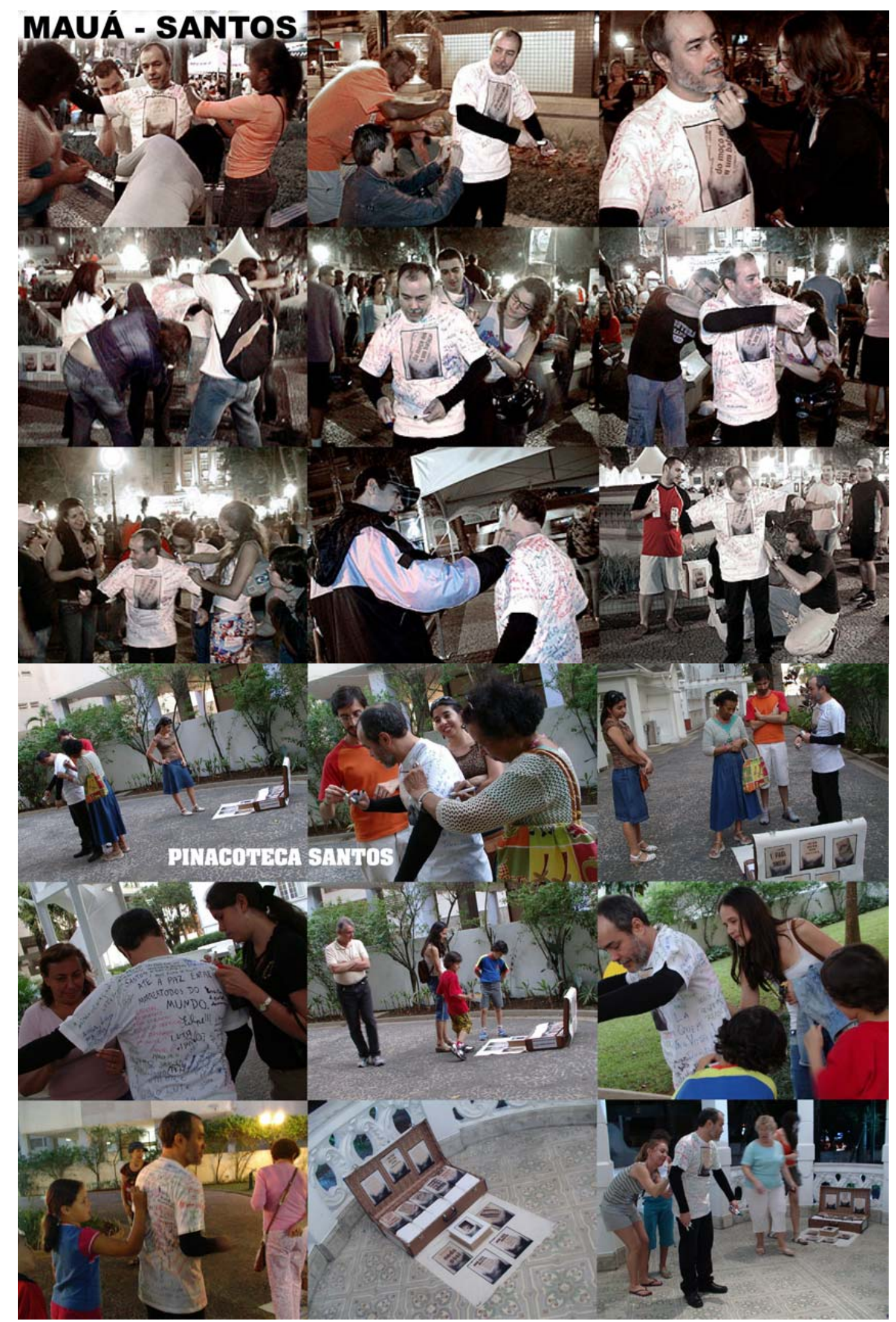

FIG. CRP-10 e 11 - Performance Participativa Corpo Coletivo, 2006 - Nardo Germano. Acima: Maratona Cultural Caros Amigos de Santos. Praça Mauá. Abaixo: Pinacoteca Benedicto Calixto, Santos. SP, 2006. http://www.nardogermano.com/autoretratocoletivo/corpocoletivo 

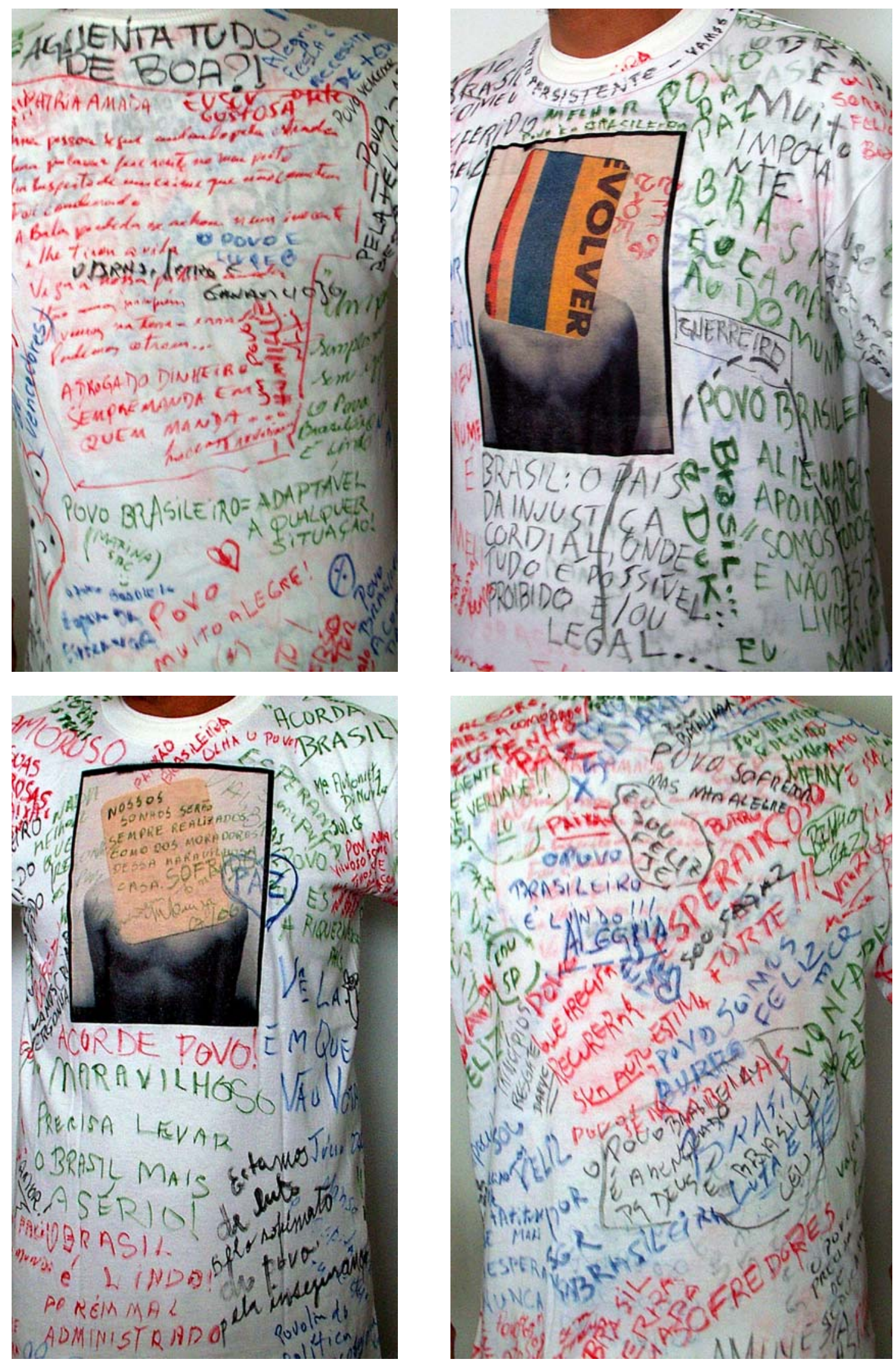

FIG. CRP-12 a 15 - Performance Participativa Corpo Coletivo, 2006 - Nardo Germano. Autografia Plural e Palimpsesto. http://www.nardogermano.com/autoretratocoletivo/corpocoletivo 
O núcleo de intervenções urbanas revela-se fundamental uma vez que a inserção da discussão sobre identidade no espaço público flagra o indivíduo no contexto social, no momento em que seu ser ontológico está inserido no coletivo. As experiências que realizei em 2006 ocorreram tanto em espaços institucionais quanto espaços externos. Contudo, as intervenções urbanas da performance Corpo Coletivo privilegiam de modo especial os espaços públicos não protegidos, como ruas, praças públicas e largos, cuja história os caracterize como espaços políticos, onde o cidadão exerça o seu papel como sujeito da história, de modo a colocá-lo nessa condição para participar do Auto-Retrato Coletivo como sujeito de sua própria identidade.

A Performance Corpo Coletivo destina-se a todos: ao público em geral, sem distinção de raça, cor, sexo, religião, idade, escolaridade etc, não excluindo os freqüentadores de galerias de arte e museus. Trata-se de alcançar também o público que não tem acesso aos espaços artísticos e culturais. Reconheço consonâncias entre estas performances e o programa ambiental de Hélio Oiticica, na medida em que a obra se estende para a experiência cotidiana no espaço público pelo princípio de apropriação do "mundo ambiente"149 como contexto.

Enquanto Manifestações Ambientais, as performances propõem a "participação dinâmica do 'espectador' agora considerado 'participador'”, colocando em prática o conceito de antiarte enquanto “ 'realização criativa' isenta de premissas morais, intelectuais ou estéticas"150, atuando no sentido de motivar a criação. Segundo Celso Favaretto ${ }^{151}$, o artista logra motivar a criação "nela integrando o coletivo pelo redimensionamento cultural dos protagonistas (artista e participantes)", lembrando que "ao situar as operações nas ruas, parques, morros, pavilhões de exposições industriais etc., Oiticica acredita que o público se aproxima sem constrangimentos, com total disponibilidade, de experiências que na arte são

\footnotetext{
${ }^{149}$ OiticiCA, Hélio. Aspiro ao Grande Labirinto, Rio de Janeiro, Editora Rocco Ltda., 1986, p.79

${ }^{150}$ OiticiCA, Hélio. Aspiro ao Grande Labirinto, Rio de Janeiro, Editora Rocco Ltda., 1986, p.77

${ }^{151}$ FavaretTo, Celso. A Invenção de Hélio Oiticica, São Paulo, EDUSP, 1992, p.121-129
} 
segregadas", o que vale dizer que as apropriações ambientais instauram condições mais propícias à criação pois "não se distinguem aí níveis - de elaboração de obras, de circulação e de significação social: a ambientação reúne artista, participantes e "mundo"” sem distinções hierarquizantes, concluindo que "as Manifestações Ambientais são lugares de transgressão em que se materializam signos de utopias (de recriação da arte como vida)".

Nesse sentido, as performances de Corpo Coletivo parecem potencializar seu poder transformador na direção de uma discussão da identidade coletiva a níveis mais efetivos em termos de consciência e penetração social.

A performance participativa Corpo Coletivo foi inaugurada em 21 de maio na Virada Cultural SP2006 como uma ação de rua realizada por mim e meus alter-egos masculino e feminino, representados por meu irmão gêmeo Agnus Valente e pela atriz Zilma Barros. A performance comporta três modalidades: exposição ambulante; coleta de fotos e, como eixo central, a performance coletiva com inscrições nas camisetas - modalidade que dá título à performance como um todo. Em Julho, foi realizada na Maratona Cultural de Santos e a seguir na Pinacoteca Benedicto Calixto, na mesma cidade.

A exposição ambulante constitui-se de uma caminhada a pé entre os pontos de parada para a performance principal, com exibição de imagens estampadas nas camisetas vestidas pelos performers e da mala de viagem que também veicula o contexto da série (trata-se aqui da obra Auto-Retr_Ato_Coletivo, apresentada em "Uma Viagem de 450 Anos", que ganha as ruas para cumprir a proposta participativa de inscrições nas camisetas que foi impossibilitada naquele evento do SESC-Pompéia). 
A intervenção urbana em trânsito que se realizou, em espaços públicos desprotegidos como as ruas dos Centros Históricos de São Paulo e de Santos, promove um estranhamento ${ }^{152}$ no âmbito da recepção da obra por conta das composições difíceis e imagens fragmentadas das colagens, da singularidade da mala de viagem, da descontextualização dos paramentos dos performers em relação ao ambiente cotidiano e à vestimenta dos transeuntes. Essa intervenção urbana ambulante incorpora, cumulativamente, a exibição das camisetas com as inscrições dos participantes, como uma pichação em trânsito, tornando-se mais um elemento de estranhamento que provoca a percepção do espectador.

A coleta de fotos constitui a proposição "Cabeça Coletiva", colocada nos seguintes termos: "Deposite aqui uma foto $3 \times 4$, nova ou antiga, para completarmos a obra juntos e compormos uma cabeça coletiva”. Uma urna com um auto-retrato acéfalo adesivado na tampa recebe as fotos doadas, que são lançadas através do recorte vazado da cabeça ausente. A partir do próprio registro das fotos de documento, a proposição é que as várias fotos constituirão uma cabeça coletiva, atemporal, na medida em que desrespeita a regra da atualidade da imagem. Assim, fotos dos participantes, nos mais diferentes registros de envelhecimento do material fotográifco e nos mais diferentes registros de época, encontram-se sincronicamente na "Cabeça Coletiva", numa identidade reveladora (e denunciadora ou acusadora) dos elementos de tipologia identitária empregados nas diferentes épocas. Essa proposição tem um caráter lento e cumulativo, considerando-se o fato de encontrar o público casualmente, numa circunstância particular de seu cotidiano, o que não garante que tenha uma foto para a doação.

\footnotetext{
${ }^{152}$ As imagens em circulação com a exposição ambulante são impressões dos auto-retratos da obra Sujeitos, cujos elementos de estranhamento (Chklóvski) foram apontados no Cap.1. Para maiores detalhes desses elementos reiterados nesta ação de rua, remeto àquele capítulo.
} 
Em cada ponto de parada da performance, a mala de viagem, contendo camisetas dobradas como corpos alojados lado a lado, é aberta e "instalada" no espaço, com sua capa estampada de imagens estendida diretamente no calçamento, com a urna "Cabeça Coletiva" posicionada sobre ela. Tendo a cidade como cenário, a instalação compõe uma cena surrealista e cria o ambiente para a intervenção.

Nesse cenário, tem início a performance Corpo Coletivo propriamente dita, cujo título faz referência à expressão "corpo-coletivo" formulada por Lygia Clark como "troca de conteúdos psíquicos entre as pessoas a partir da vivência em grupo de proposições comuns"153, o que "no plano filosófico significa entender que a repressão ou liberdade do indivíduo passa pelo social, logo é uma questão política"154 que se coloca em curso a partir da experiência de cunho psíquico. A minha transposição do conceito de "corpo-coletivo" para a série Auto-Retrato Coletivo desloca-se para uma troca de conteúdos dominantemente ideológicos, tendo na dialética identidade individual/coletiva a correspondência com a poética do corpo de Lygia Clark, na medida em que:

"A dialética básica de Clark é a tensão entre o dentro e o fora, o eu e o outro, o intelectivo e o sensório, o prazer e a realidade. À arte como consolo, como refúgio, como prazer sublimado, contrapõe a criação como liberação do reprimido, como corpo ressurrecto em agenciamento coletivo." 155

Nesse sentido, as identidades reprimidas encontram no espaço público em que a performance ocorre a possibilidade de exercer uma consciência crítica pois, nesse caso,

“a participação não é o processo de atualização de propostas; as ações significantes acontecem antes do significado, exatamente para produzi-lo. Por isso, os participantes não 'criam'; 'experimentam a criação', recriando-se ao mesmo tempo como sujeitos. Daí o criticismo do sistema ambiental." "156

\footnotetext{
${ }^{153}$ ClARK, Lygia.. Lygia Clark, Rio de Janeiro, edição Funarte, 1980, p.41

${ }^{154}$ Milliet, Maria Alice. Lygia Clark: Obra-Trajeto, São Paulo, EDUSP, 1992, p.145

${ }^{155}$ Milliet, Maria Alice. Lygia Clark: Obra-Trajeto, São Paulo, EDUSP, 1992, p.109

${ }^{156}$ FavaretTo, Celso. A Invenção de Hélio Oiticica, São Paulo, EDUSP, 1992, p.127
} 
Esta proposta de participação convida o público a expressar sua identidade, fazendo intervenções e inscrições multicores sobre as camisetas, que se tornam um repositório dos pontos de vista dos participantes. Resulta daí um produto heteróclito: ao contexto das obras da série (impresso na camiseta do artista e seus alter-egos como também nas camisetas acondicionadas na mala de viagem instalada no espaço), acrescentam-se cumulativamente contextos novos, compostos por palavras, frases e desenhos que o próprio participante insere na obra, num procedimento por vezes muito próximo da pichação em que as contribuições se atropelam ${ }^{157}$, sobrepondo-se umas às outras, numa espécie de palimpsesto.

Durante a ação, os participantes testemunham as intervenções dos outros, comentam, questionam — dialogam com o universo apresentado pelo artista e com o dos demais participantes. Instaura-se uma situação de debate de idéias em torno desse corpo coletivo ideológico, seja no "aqui-agora" do debate presencial, em que os autores das frases estão no pleno ato da participação e discutem seus pontos de vista conflitantes entre si e/ou com o artista, seja através de uma inscrição registrada a posteriori, como réplica ao ponto de vista deixado por um participante já ausente, tendo na camiseta o campo onde o diálogo se constrói.

Durante a performance, quando os participantes preenchem toda a área livre, uma nova camiseta é vestida sobre as anteriores. Numa série de performances consecutivas, o conjunto de camisetas cumulativamente vestidas compõe um novo palimpsesto que permite visualizar as inscrições sobrepostas através da malha do tecido.

\footnotetext{
157 “Atropelar" tem aqui o sentido comumente empregado entre pichadores como "sobrepor", pichar em cima da pichação do outro, comprometendo sua legibilidade.
} 
As intervenções revelam formatividades: No sentido de que "a pessoa é uma forma" ${ }^{158}$, cada participante contribui com seu modo singular e irrepetível para a pluralidade solicitada pela proposta. A diversidade de pontos de vista e de formatividades registradas no conjunto de camisetas que compõem o objeto resultante das performances revela uma

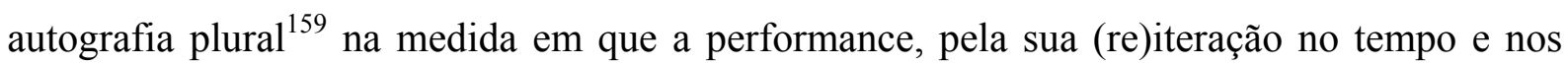
diversos pontos da cidade, acumula as inscrições manuais realizadas com os bastões coloridos que trazem o traço, a caligrafia de seus autores, bem como o sentido particular que atribuem à sua participação pela escolha da inscrição a fazer na relação com as cores empregadas.

Os alter-egos masculino e feminino, que na origem do projeto posaram para a obra Sujeitos como um "eu por designação", conclamam os participantes de improviso ${ }^{160}$ e registram em fotografia e vídeo as ações performáticas realizadas. Nesse caso, produzem o que considero como "auto-retrato coletivo por designação": fotografias produzidas ad hoc por Agnus Valente e Zilma Barros como uma extensão de mim, expandindo-se dessa forma o conceito de auto-retrato coletivo (figs.CRP-01 a 05, 08 a 11). Por outro lado, também se configura o que considero como "auto-retrato coletivo ipsis litteris" (fig.CRP-8, 3:2), ou seja, registros fotográficos realizados por mim, do ponto de vista de quem recebe as intervenções no momento mesmo da ação conjunta com os participantes no pleno exercício da liberdade de expressão proposto.

Constitui-se, assim, um corpus híbrido entre o autográfico plural e o múltiplo, composto pelos vários objetos que remetem à realização da proposição participativa.

\footnotetext{
${ }^{158}$ PAREYSON, Luigi. Estética - Teoria da Formatividade.R.Janeiro, Ed.Vozes,1993, p.76 (tradução: Ephraim Ferreira Alves)

${ }^{159}$ GenetTE, Gérard. L'Oeuvre de l'Art: immanence et transcendence Paris, Éditions du Seuil, 1994. p.84.

${ }^{160}$ A improvisação aqui é sustentada pela intuição dos alter-egos a partir de uma intensa imersão no contexto de todo o projeto, motivações e proposições do autor. Em cada local, ambos buscaram estabelecer um canal de comunicação e difundir a proposta, tanto no plano do inteligível quanto do sensível.
} 
Retomando o pensamento de Gérard Genette ${ }^{161}$ : a performance é um evento físico, um objeto autográfico único que, de um lado, possibilita uma arte autográfica plural pela iteração, e, de outro, possibilita uma arte autográfica múltipla, pelo registro. Entre esses objetos resultantes da ação performática, cada camiseta em sua unidade bem como o grupo de camisetas exibido num único bloco constituem uma arte autográfica múltipla, nos termos de Genette, como registro da autografia plural dos participantes (fig.CRP-12 a 15). Do mesmo modo, o registro das performances em fotografia se constitui num objeto artístico, enquanto arte autográfica múltipla composta pelos auto-retratos coletivos por designação ou ipsis litteris, na medida em que essas imagens flagram momentos da ação performática em coletividade. Por outro lado, esses registros fotográficos, devido às características indiciais que lhe são próprias, reversivelmente remetem às performances que lhes conferiram existência. Numa aproximação com o conceito de obra como acontecimento, considero que a obra não é somente os objetos artísticos resultantes mas também a performance em si, no espírito de intervenção urbana em que se realizou.

A performance Corpo Coletivo, essa obra "acontecimento", é coletiva não apenas pelo fato de serem três performers envolvidos na ação, mas sobretudo porque o acontecimento que dá vida à obra depende da atuação do público e assume um caráter ideológico. Desenvolvendo-se em clima de comunhão anárquica, não há fila nem palavras de ordem, nem censura nem pressa, propondo-se uma ação conjunta de um público livre para participar e/ou assistir à participação dos demais.

Nesse corpo-a-corpo com o espectador, ofereço-me performaticamente como suporte para a expressão do outro. A partir dessa condição inicial, contudo, deixo de ser apenas

\footnotetext{
${ }^{161}$ Genette, Gérard. L'Oeuvre de l'Art: immanence et transcendence Paris, Éditions du Seuil, 1994. p.84.
} 
suporte para a obra e para a participação, desenvolvendo um fenômeno que Hélio Oiticica reconhecia como uma "incorporação total", que consiste na "incorporação do corpo à obra e da obra ao corpo"162, realizando-se enquanto forma e conteúdo. Enquanto forma, a incorporação envolve inclusive o corpo do outro, dos espectadores-participantes, na medida em que durante a ação realizo minha performance, alongando-me, dobrando-me, contorcendo-me conforme as necessidades de apoio requeridas ou induzidas pelos participantes no ato de suas intervenções. Do mesmo modo, os participantes, em sinergia comigo e com os demais participantes, desenvolvem suas performances que revelam suas capacidades intelectuais, poéticas e locomotoras ${ }^{163}$ à medida que naturalmente articulam uma gestualidade e uma expressão corporal próprias, tal como se apoiar, se abaixar ou se ajoelhar no chão para efetivar sua participação. Buscando um espaço e uma posição entre os demais, os participantes aglomeram-se numa relação interpessoal sem hierarquização entre artista e público, sem tabus nem constrangimentos, no intuito de cumprir o impulso do jogo em desenvolvimento, num esforço que revela o princípio agôn ${ }^{164}$ se efetivando em momentos alternados de ordem e desordem (ludus/paidia). Em termos de conteúdo, ocorre uma incorporação quando os participantes fazem a leitura oral dos textos, comunicando ao artista e aos demais participantes o teor das inscrições, muitas vezes acrescentando comentários sobre as mesmas. A aura da performance em si, entretanto, guarda um caráter de transformação, na medida em que "o imaginário extrojetado torna-se presente no espaço social onde o pensamento vive pela ação"165 e renova-se por rememoração, quando cada um dos participantes em sua atividade cotidiana retorne ao local da experiência, o que reitera e intensifica o efeito da ação sobre sua consciência de indivíduo inserido no social, numa incorporação enquanto memória.

\footnotetext{
${ }^{162}$ OiticiCA, Hélio. Entrevista com Ivan Cardoso in: R Fluchetti: Vampirismo. Rio de Janeiro, Ebal, 1990, p.86.

${ }^{163}$ BARILLI, Renato. Curso de Estética, Lisboa, editorial Estampa, 1992 p.124

${ }^{164}$ CAILlois, Roger. Les Jeux et les Hommes: Le masque et le vertige. Paris, Gallimard, 1958, pp.55-57

${ }^{165}$ MiLliET, Maria Alice. Lygia Clark: Obra-Trajeto, São Paulo, EDUSP, 1992, p.110
} 
As performances participativas de Auto-Retrato Coletivo ocorreram na triste “circunstância de comunicação" "166 dos ataques do PCC nas semanas próximas tanto da Virada Cultural SP-2006 quanto da Maratona Cultural de Santos e das apresentações na Pinacoteca Benedicto Calixto, envolvendo a capital paulista e cidades litorâneas da baixada santista. Tais acontecimentos traumatizaram a população nesse período, sobre os quais o público se manifestou de forma recorrente. Questionando o estigma de uma identidade coletiva desviante, associada ao crime e à violência, que na semana anterior havia causado indignação na sociedade por conta das abordagens da polícia a populares, com mortes sumárias de suspeitos, a equação identidade coletiva e criminalidade que a obra discute tornou-se um campo aberto para a reversão do trágico, para a reflexão e manifestação crítica.

O rompimento das fronteiras entre arte e vida exige responsabilidades: nas performances realizadas de maio a julho de 2006, a situação instaurada com esse contexto trágico exigiu da parte dos performers uma atuação especialmente cuidadosa, brechtiana, em oposição à katharsis aristotélica ${ }^{167}$ que conduz ao transe emocional e alienante. Aqui, efetivamente, pode-se verificar que a catarse em Corpo Coletivo compreende o conceito de catarse na perspectiva de uma "identificação irônica"168, de distanciamento em relação à experiência trágica vivenciada socialmente. Na Poética do Jogo aqui engendrada, ganha importância a noção de jogo "as a special form of activity, as a 'significant form', as a social

\footnotetext{
${ }^{166}$ ECO, Umberto. As Formas do Conteúdo. S.Paulo, Perspectiva/Edusp, 1974 (trad: Pérola de Carvalho), p.125

${ }^{167}$ Aristóteles, Poética. São Paulo, Nova Cultural, 1987. (tradução: Eudoro de Souza).

${ }^{168}$ JAUSS, Hans Robert. Pour une esthétique de la réception. Paris, Gallimard, 1978, pp.152-153
} 
function" $" 169$ que nessas performances participativas se tornou mais perceptível. Os participantes exerceram sua cidadania, discutindo sua identidade, expressando seu ponto de vista sobre a violência, sobre o governo, a polícia, os políticos, o sistema etc. Diante do trágico, viram-se com um instrumento do universo da cultura em suas mãos: os bastões coloridos com o quais foram conclamados ao pensamento e não ao terror.

Assim, a proposição privilegia o anti-trágico, numa performance grupal que alcança momentos de esculturalidade plástica de um corpo coletivo em que artista e público se incorporam, se irmanam numa identidade a um tempo única e plural, enquanto as camisetas brancas acumulam os traços plurais do imaginário coletivo. Nesse contexto ideológico, minhas performances participativas de intervenção urbana em espaço público cumpriram sua vocação Arte/Vida com uma metafórica reversão coletiva do trágico para o Utópico.

\footnotetext{
${ }^{169}$ HuIZINGA, Johan. Homo Ludens - a study of the play element in culture. Boston, Beacon Press, $5^{\text {a }}$ ed.,1966, p.4. Segue tradução: noção de jogo "como uma forma especial de atividade, como uma 'forma significante', como uma função social” (t.a.)
} 


\title{
Capítulo 3 - Auto-Retrato Coletivo ON-Line: Presenças Distantes
}

\author{
“L'interactivité nest pas seulement \\ une commodité technique et functionnelle, elle implique \\ physiquement, psychologiquement, sensiblement, \\ le spectateur dans une pratique de transformation." \\ “Les 'communautés virtuelles' du réseau internet \\ recherchent et pratiquent de nouvelles formes \\ de participation collective [...\} Les conditions inédites qui \\ se mettent en place vont créer progressivement \\ un terrain favorable, un terrain sur lequel vont fleurir \\ de nouvelles utopies." 170
}

Fred Forest

A disponibilização de AlterEgo on-line inaugura uma nova "abertura dialógica"171 da série Auto-Retrato Coletivo, enquanto obra mediada instantaneamente no contexto das obras em movimento ${ }^{172}$, sendo seguida por Doe seu Rosto/Give me your Face e ANDROMAQUIA On-Line. Investe-se na relação do conceito de participação com os graus de abertura da obra à recepção, propondo-se a noção de abertura de terceiro grau ${ }^{173}$, cuja especificidade se estabelece na dominância de processos participativos que se realizam pela interatividade tecnológica e na relação homem-máquina, no contexto das Novas Tecnologias de Comunicação.

A série Auto-Retrato Coletivo, a partir de sua inserção no âmbito das novas tecnologias com a digitalização das colagens dos auto-retratos, promoveu uma ação

\footnotetext{
${ }^{170}$ Forest, Fred. Pour un Art Actuel - L'art à l'heure d'Internet. Paris, L'Harmattan, 1998, p133 e 55, respectivamente. Seguem Traduções: "A interatividade não é somente uma commoditie técnica e funcional, ela implica fisicamente, psicologicamente, sensivelmente, o espectador numa prática de transformação" | "As 'comunidades virtuais' da rede internet pesquisam e praticam novas formas de participação coletiva [...] As condições inéditas que se colocam vão criar progressivamente um terreno favorável, um terreno sobre o qual vão florescer novas utopias."

${ }^{171}$ Bakhtin, Mikhail. La Poétique de Dostoievski, édition du Seuil, 1970, p.347

172 Tavares, Monica. A Recepção no Contexto das Poéticas Interativas. S.Paulo, SP. Tese de Doutorado ECAUSP. 2000, pp.93-101 Remeto novamente à distinção de Tavares entre participação mediada corporal, automática e instantaneamente, esta última no contexto das poéticas interativas.pp.74-101

${ }^{173}$ PlAZA, Julio. Arte e Interatividade: autor-obra-recepção, 2000, p.10. Acessado em 25/06/2003, [http://www.plural.com.br/jplaza/texto01.htm].
} 
reflexionante de caráter retroativo, propiciando um redimensionamento da percepção do simulacro em relação aos ensaios anteriores, Auto-Objeto e Sujeitos (cf. Cap.II). Agora, no que tange às aberturas dialógicas, as estratégias de interatividade serão organizadas no corpo intertextual dessas colagens digitalizadas, utilizando recursos para sensibilização ao cursor bem como para intervenção do espectador sobre sua estrutura e outros recursos disponíveis. Considerando que "uma imagem interativa, mesmo engendrada em sua origem por um aparelho ótico (foto, cinema, televisão), não tem os mesmos efeitos de sentido que uma imagem tradicional com a qual nenhuma interação é possível”"174, instauram-se novas perspectivas para a discussão da identidade coletiva em ambiente digital. Com a passagem das colagens para o código binário, foi possível proceder a uma aplicação de "modelos de comportamento" 175 , através de animação ou interatividade - condição sine qua non para que a imagem digitalizada passe a figurar o modelizável -, sem esquecer que "cabe ao artista projetar os esquemas de comportamento da imagem e as conseqüentes possibilidades de representação do objeto, além de programar a capacidade de o receptor descobrir-se em sua alteridade" ${ }^{176}$, segundo as intencionalidades em curso no seu projeto artístico.

Nesse contexto tecnológico, com "a recuperação interativa dos dados armazenados", possibilita-se a escolha de elementos apresentados ao espectador de forma simultânea que "favorece uma arte da combinatória, uma arte potencial, em que, em vez de se ter uma 'obra'

\footnotetext{
${ }^{174}$ Couchot, Edmond. A Tecnologia na Arte: da fotografia à realidade virtual. Porto Alegre, UFRGS editora, Col. Interfaces, 2003, pp. 156-157 (grifo nosso)

${ }^{175}$ COUCHOT, Edmond "Da Representação à Simulação: Evolução das Técnicas e das Artes da Figuração". In: Parente, André (org.) Imagem-Máquina: A Era das Tecnologias do Virtual, R. Janeiro, Editora 34, 1993, p.43. Nesta reflexão sobre a inserção de Auto-Retrato Coletivo no contexto das poéticas interativas, estou considerando uma noção expandida de "modelos de comportamento", não apenas como o comportamento do meio natural, como dos peixes e pássaros exemplificados por Couchot, mas também numa perspectiva artística, incluindo a noção de um comportamento sensível ao cursor e também anamórfico que permita distorções ou mesmo abstrações da imagem interativa implementadas por algoritmo etc.

${ }^{176}$ TAVARES, Monica. "O Pacto de Leitura das Poéticas Interativas" in: Anual da Compós, 2004, p.9
} 
acabada, tem-se apenas seus elementos e suas leis de permutação definidas por um algoritmo combinatório" ${ }^{177}$, que condicionam a obra à ação do espectador. Nessa perspectiva,

"A obra interativa só tem existência e sentido na medida em que o espectador interage com ela. Sem essa interação, de que depende totalmente, ainda que reduzida apenas a um gesto elementar, ela continua sendo uma potencialidade não-perceptível"178.

Configura-se uma Poética da Ação, em que “o artista é o responsável pela idéia, pela narrativa, pelo conceito da obra, que engloba tanto a escolha dos elementos que dela tomarão parte, quanto o algoritmo combinatório, que circunscreve a seqüência de regras para o tratamento e arranjo desses elementos" ${ }^{\prime 19}$, tendo no computador um auxiliar que, numa mediação caracterizada pela instantaneidade, viabilizará a exploração sistemática pelo interator em tempo real.

Observa-se a dominância da função poética "necessariamente articulada na dialética com a função conativa" ${ }^{\prime 180}$ da linguagem: no intuito de inserir o espectador na recriação, o artista engendra trocas recíprocas entre o espectador e a obra, cuja atualização ancora-se no pressuposto de que a ação do espectador esteja vinculada ao repertório do artista, "ao estoque de símbolos conhecidos e por ele atualizados que determinam sua competência e sua performance em decifrar códigos e articular significações"181, denotando a necessária interpretação da obra para colocar-se no papel de interator.

Refletindo sobre essa questão, destaca-se uma dinâmica dialógica de repertórios que se estabelece com a contribuição do espectador para a construção de seus significados, longe de

\footnotetext{
${ }^{177}$ MACHADO, Arlindo. "Hipermídia: O Labirinto como Metáfora” In: Domingues, Diana. A Arte no Século XXI: A Humanização das Tecnologias. SP, Editora unesp, 1997, pp.145-146

${ }^{178}$ Couchot, Edmond. “O Tempo Real nos Dispositivos Artísticos” In: Interlab: Labirinto do Pensamento Contemporâneo. Fapesp/Iluminuras, 2002, p.104

179 Tavares, Monica. "O Pacto de Leitura das Poéticas Interativas” ” in: Anual da Compós, 2004. p.4

${ }^{180}$ TAVAres, Monica. A Recepção no Contexto das Poéticas Interativas. S.Paulo, SP. Tese de Doutorado ECAUSP. 2000, p.152

${ }^{181}$ TAVArES, Monica. “O Pacto de Leitura das Poéticas Interativas” in: Anual da Compós, 2004, p.6
} 
uma prerrogativa autoral "monologicamente fechada" $"$. Na perspectiva dialógica da interatividade, "a obra não é mais fruto exclusivo da autoridade do artista, mas se engendra durante um diálogo em tempo real com o espectador" ${ }^{\text {183 }}$. O dialogismo bakhtiniano, que transpomos aqui para o campo semiótico, parece encontrar respaldo nas palavras de Couchot, para quem esse diálogo se efetiva

\begin{abstract}
"no sentido amplo, em que intervêm outras modalidades além da linguagem, a exemplo das modalidades visuais, sonoras, gestuais, e até mesmo táteis; diálogo que, ao mesmo tempo que se aproxima da comunicação lingüística, se distancia também pelos efeitos do tratamento numérico da informação que se infiltra no cerne das operações"
\end{abstract}

Nessa perspectiva, configura-se esse "espaço intertextual, que constitutivamente a imagem interativa é"185 pela sua vocação polifônica, pela "pluralité de voix et des consciences indépendantes et distinctes" ${ }^{\prime 186}$ que podem nela se alojar e agir. Enfatiza-se, aqui, o novo papel do espectador no contexto das obras interativas, tal como proposto por Weissberg:

"Il me semble nécessaire de délimiter plus précisément la signification du néologisme proposé de spect-acteur. Je précise que dans mon esprit, la notion d'acteur ne désigne pas ici les espaces de liberté dont jouit l'interprète, au sens théâtral ou encore l'acteur dans une acception sociologique (l'acteur social). Il renvoie directement à la notion d'acte, quasiment au sens gestuel, par opposition à l'appréciation mentale. Et le trait d'union est essentiel, puisqu'il accouple la fonction perceptive "spect" (regarder) à l'accomplissement de l'acte." 187

\footnotetext{
${ }^{182}$ BAKhtin, Mikhail. Questões de Literatura e de Estética (A Teoria do Romance), São Paulo, Ed.Unesp, $4^{\mathrm{a}}$ edição, 1998. p.103

${ }^{183}$ CouchOT, Edmond. “O Tempo Real nos Dispositivos Artísticos” In: Interlab: Labirinto do Pensamento Contemporâneo. Fapesp/Iluminuras, 2002, p.104

${ }^{184}$ Couchot, Edmond. “O Tempo Real nos Dispositivos Artísticos” In: Interlab: Labirinto do Pensamento Contemporâneo. Fapesp/Iluminuras, 2002, p.104

185 Tavares, Monica. A Recepção no Contexto das Poéticas Interativas. S.Paulo, SP. Tese de Doutorado ECAUSP. 2000, p.152

${ }^{186}$ Bakhtin, Mikhail. La Poétique de Dostoievski, édition du Seuil, 1970, p.32. Segue tradução: "pluralidade de vozes e de consciências independentes e distintas" (t.a.)

${ }^{187}$ WeISSBERG, Jean-Louis. "Retour sur Interactivité" In: Présences à Distance. [http://hypermedia.univparis8.fr/weissberg/presence.htm] Segue tradução: "parece-me necessário delimitar mais precisamente a significação do neologismo proposto spect-acteur [spect-ator]. Deixo bem preciso que em meu espírito, a noção de ator não designa aqui os espaços de liberdade nos quais o intérprete representa, no sentido teatral ou ainda o ator numa acepção sociológica (o ator social). Ele remete diretamente à noção de ato, num sentido quase gestual, por oposição à apreciação mental. E o traço de união é essencial, pois ele casa a função perceptiva "spect" (ver) ao acabamento do ato". (t.a.)
} 
Numa perspectiva dialógica com o próprio regime temporal tecnológico, "une toute autre logique, celle de la temporalité humaine de saisie, de questionnement, parfois de doute, de décision et finalement d'action"188 constitui-se a condição de spect-acteur, que confere uma nova dimensão à função perceptiva daquele que explora o campo dos possíveis da obra interativa.

No contexto da discussão identitária de Auto-Retrato Coletivo, o meu foco de interesse prioriza o papel desse spect-acteur na medida em que "o procedimento autoral inerente à poética da ação busca despertar o envolvimento e a operação do receptor a partir de uma condição precípua, que é a de ele descobrir-se a si mesmo" ${ }^{\text {"189 }}$, colocando-o numa perspectiva dialógica em relação ao apagamento da identidade promovida pelos estigmas identitários sobre as individualidades.

\subsection{AlterEgo ${ }^{190}$ : o Dialético e o Dialógico}

Em AlterEgo (fig.ALT-01 a 21) a proposta poética consiste em configurar o monitor como um ambiente psicológico, para um mergulho metafórico do espectador na dialética ego/alter-ego. O pressuposto da interação desejada sustenta-se num duplo cruzamento identitário, na medida em que ofereço o meu auto-retrato como retrato do outro mas propondo em contrapartida, com a adesão do espectador, a constituição do outro como auto-retrato.

\footnotetext{
${ }^{188}$ WeISSBERG, Jean-Louis. "Les Paradoxes de la Téléinformatique” In: Présences à Distance. [http://hypermedia.univ-paris8.fr/weissberg/presence.htm] Segue tradução: "uma outra lógica bem diferente, aquela da temporalidade humana de compreensão, de questionamento, às vezes de dúvida, de decisão e finalmente de ação". (t.a.)

189 TAVARES, Monica. "O Pacto de Leitura das Poéticas Interativas” in: Anual da Compós, 2004, pp.9-10

${ }^{190}$ AlterEgo é um ensaio de auto-retrato interativo que desenvolve o tema "Identidade e Alteridade no AutoRetrato". Essa obra foi realizada entre 2003/2005 e está disponível para interação no site oficial www.nardogermano.com e também na exposição virtual Útero Cosmos desde abril de 2005 no site www.agnusvalente.com/uteroportantocosmos . Estta obra foi exibida também no FILE MEDIA ART 2006 e também pode ser acessada pelo www.file.org.br
} 

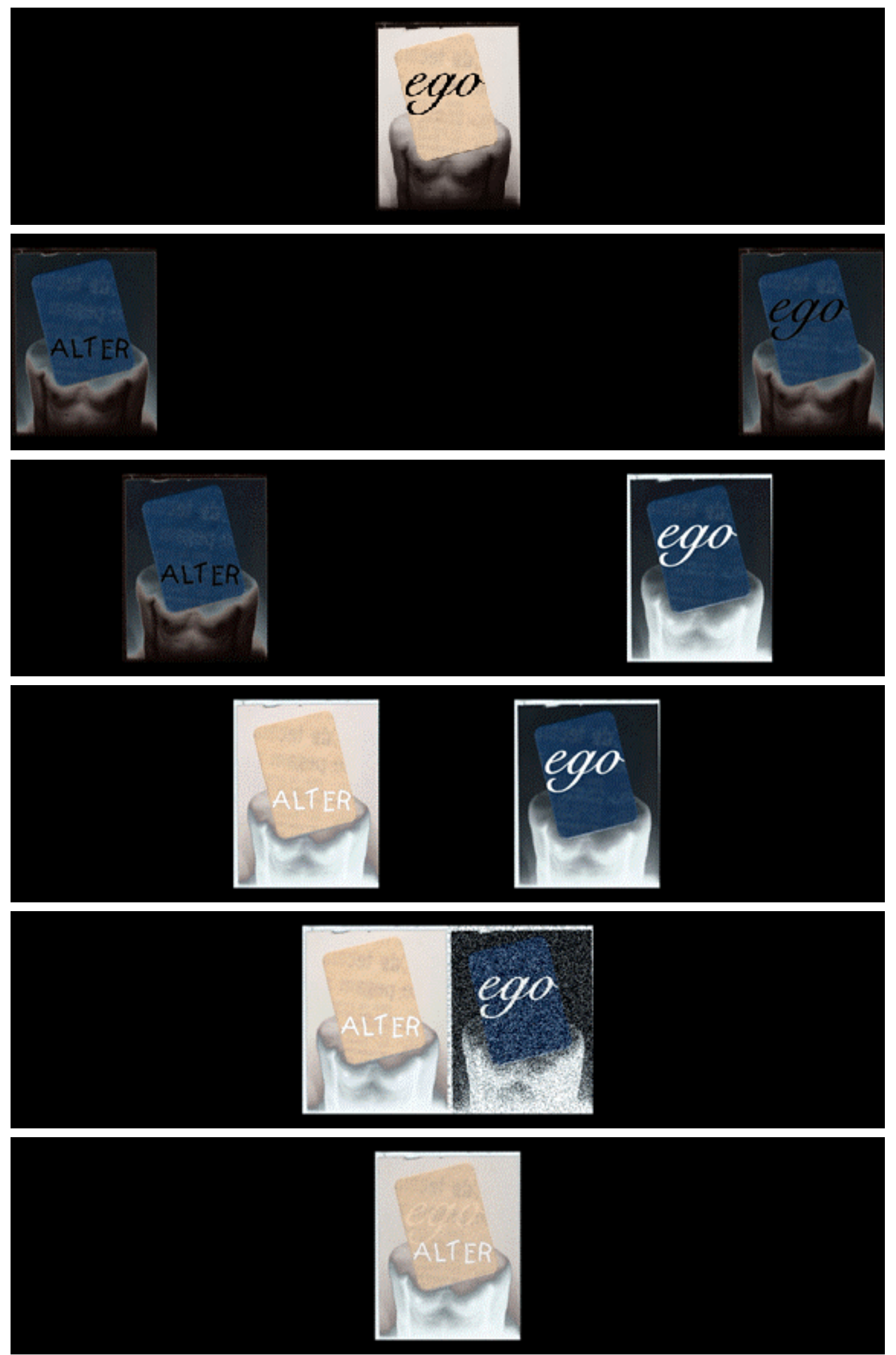

FIG. ALT-01 a 06 - AlterEgo, 2003-2005 - Nardo Germano. Primeiro Nível: um percurso possível... http://www.nardogermano.com/autoretratocoletivo/alter_ego 

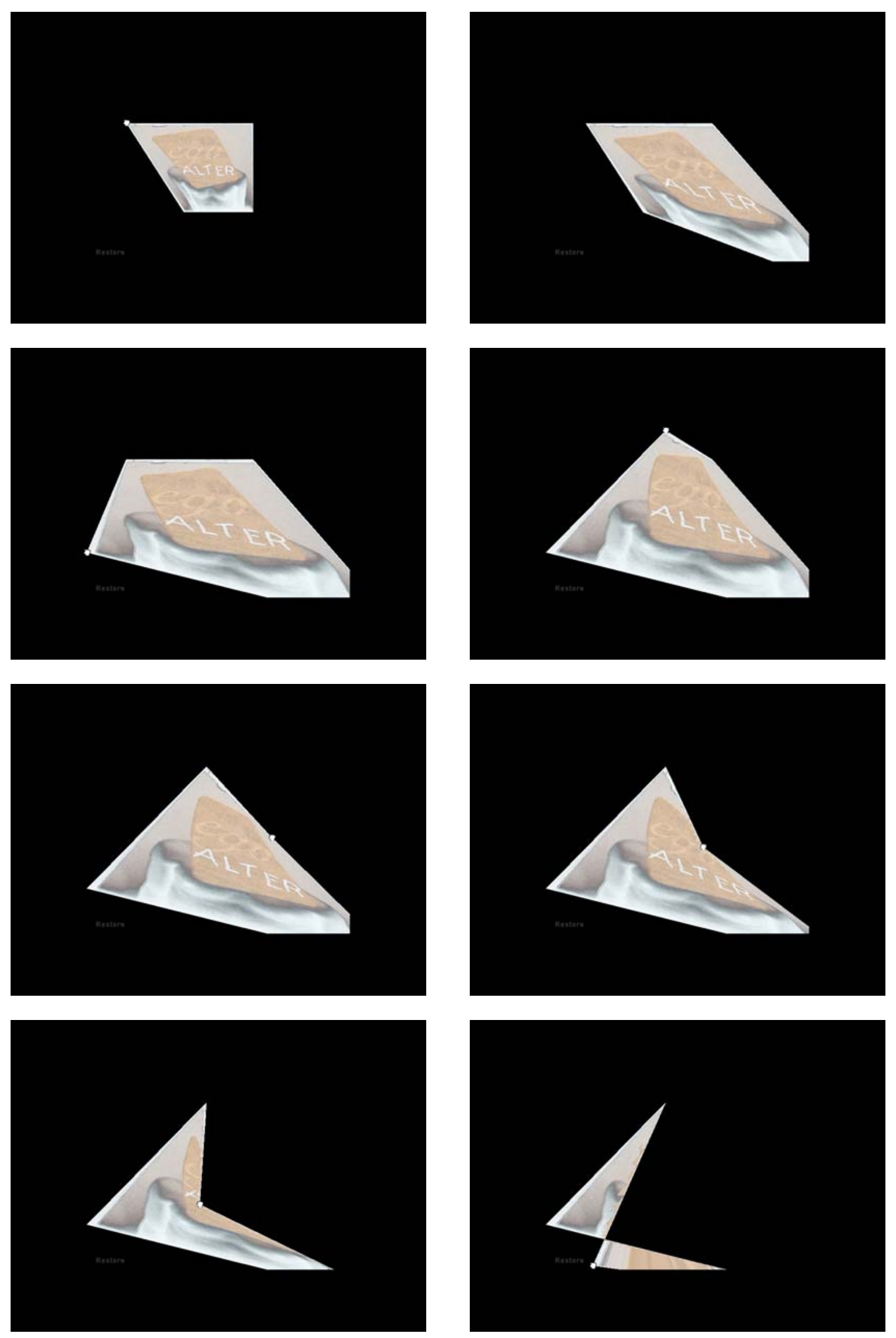

FIG. ALT-7 a 14 - AlterEgo, 2003-2005 - Nardo Germano. Segundo Nível: anamorfias. http://www.nardogermano.com/autoretratocoletivo/alter_ego 

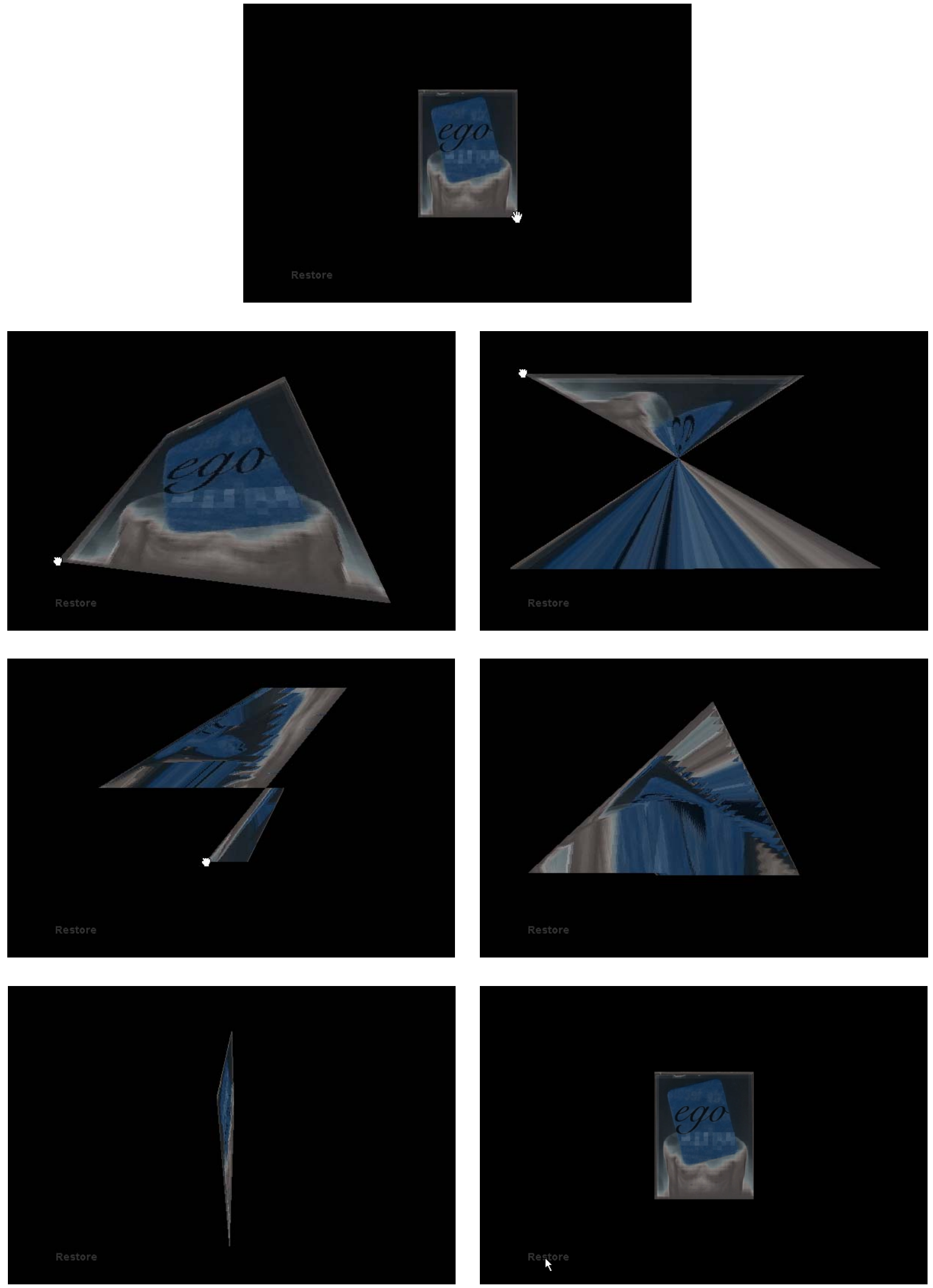

FIG. ALT-15 a 21 - AlterEgo, 2003-2005 - Nardo Germano. Uma sessão da obra interativa. http://www.nardogermano.com/autoretratocoletivo/alter_ego 
Coloca-se em novos parâmetros a discussão sobre a perda de identidade e o mecanismo de aniquilamento do indivíduo numa sociedade de massas, atualizando essa questão para o contexto das sociedades tecnológicas, na medida em que o autor aceita-se como representação do outro e esse outro, o interator, o aceita como representação de si, instaurando um ponto de partida para uma abertura dialógica on-line.

O meu auto-retrato é proposto como imagem interativa, explorando artisticamente a noção de interatividade como simulation de l'autre compreendida por Weissberg, para quem “ 'L'autre', dans la situation interactive, est un horizon, une référence pas une présence susceptible d'être dupliquée à l'identique"191, mas de estar no âmbito da representação, na medida em que:

"Le transfert de la présence opère bien entendu sur cette matière sémiotique : [...] image télé-transmise, corps modélisés et transférés dans la téléprésence contemporaine. La génération actuelle de réseaux (perfectionnement d'Internet dans la voie de la réalité virtuelle, dialogue par avatar corporéisé, etc.) concrétise cette orientation fondamentale." 192

Nesse sentido, a estrutura hipermidiática da obra organiza-se de modo a permitir que o interator delineie um percurso particular, como se metaforicamente navegasse no seu próprio Inconsciente, instaurando-se uma oscilação entre identidade e alteridade, numa problematização não apenas dialética do spect-acteur em relação a si mesmo, mas também dialógica na relação com a existência desse outro, referenciado na imagem como repositório mútuo.

\footnotetext{
${ }^{191}$ WeISSBERG, Jean-Louis. "Les Paradoxes de la Téléinformatique” In: Présences à Distance. Chapitre V Retour sur interactivité. [http://hypermedia.univ-paris8.fr/weissberg/presence.htm] Segue tradução: “ 'O outro', na situação interativa, é um horizonte, uma referência, não uma presença susceptível de ser duplicado como idêntico". (t.a.)

${ }^{192}$ Weissberg, Jean-Louis. "Les Paradoxes de la Téléinformatique" In: Présences à Distance.

[http://hypermedia.univ-paris8.fr/weissberg/presence.htm] Segue tradução: "A transferência da presença opera, bem entendido, sobre esta matéria semiótica: [...] imagem tele-transmitida, corpos modelizados e transferidos na telepresença contemporânea. A geração atual de redes (aperfeiçoamento da Internet na via da realidade virtual, diálogo por avatar corporisado, etc) concretiza esta orientação fundamental". (t.a.)
} 
A distinção fundamental entre o dialético e o dialógico que se emprega aqui consiste no fato de que enunciados contendo dois termos (como ego e alter-ego) ou julgamentos opostos "peuvent être réunis comme la thése et l'antithèse dans l'enoncé d'un même sujet, exprimant sa position dialectique unique sur la question"193, mas não estabelecem relações dialógicas, que somente podem se estabelecer se os enunciados forem partilhados por dois sujeitos diferentes. Transpondo esse conceito bakhtiniano em AlterEgo, a proposta da obra instaura um cruzamento intersemiótico na medida em que a dialética ego/alter-ego pode ser acionada pelo espectador somente através do meu auto-retrato, aqui representando a presença do outro sujeito necessário para o estabelecimento da relação dialógica.

O ambiente psicológico, instaurado no monitor por AlterEgo, não se coloca como ambiente alienado do contexto histórico. A obra, pertencente a uma série denominada AutoRetrato Coletivo que discute a construção de tipologias identitárias no âmbito ideológico, certamente contém por extensão esses elementos. Entretanto, considerada isoladamente, podese observar a introdução dos elementos históricos por meio do auto-retrato composto por uma foto de documento, pela textura do papel jornal e pelo código verbal "alter" e "ego", que se mostram inseridos na consciência do indivíduo. Nesse sentido, o que se configura tem como pressuposto que "le contenu de notre conscience et de tout l'emsemble de notre psychisme aussi bien que les énoncés particuliers par lesquels ce contenu se manifeste au dehors sont entièrement déterminés par des facteurs socio-économiques"194. Nessa perspectiva, a ideologia definida "no sentido marxista do termo, isto é, como "falsa consciência" que "nasce como mascaramento teórico [...] de concretos relacionamentos sociais e de dadas condições

\footnotetext{
${ }^{193}$ BAKHTIn, Mikhail. La Poétique de Dostoievski, édition du Seuil, 1970, p.347. Segue tradução: "podem ser reunidos como a tese e a antítese no enunciado de um mesmo sujeito, exprimindo sua posição dialética única sobre a questão" (t.a.)

${ }^{194}$ BAKHTIN, Mikhail. Écrits sur le freudisme Lausanne, éditions L'âge d'homme, 1980. p.183. Segue a tradução: "o conteúdo de nossa consciência e de todo o conjunto de nosso psiquismo bem como os enunciados particulares pelos quais esse conteúdo se manifesta externamente são inteiramente determinados por fatores sócio-econômicos" (t.a.) PS.: uma ressalva torna-se necessária quanto ao advérbio "inteiramente", pois considero essa questão de modo mais relativizado...
} 
materiais de vida" ${ }^{195}$, surge representada no ambiente psicológico do monitor como uma identidade construída externamente que, invasora, se aloja na mente do indivíduo. O efeito proposto pela obra é que, ao exercitar sua dialética ego/alter-ego, o espectador também exercite uma relação dialógica com essa outra identidade.

Tendo em vista o universo tecnológico, no qual a obra é gerada a partir de um programa que organiza as possibilidades de interação, o artista tem à sua disposição dois modos de estruturação do processo de ação/reação. No primeiro modo, incorpora ao programa um limite pré-estabelecido de articulações, “fixa a obra como possibilidades já previamente organizadas e delimitadas, a serem simplesmente atualizadas pelo receptor" e, no segundo modo, programa um jogo permutatório disponível e em aberto para esgotar-se na infinidade de suas soluções e "circunscreve a obra como "campo de possíveis' a ser explorado"196. Em ambas as situações, o espectador, enquanto interator, participa como o elemento que atualiza a obra. Contudo, o segundo modo configura uma relação dialógica, na medida em que o interator explora um campo de possíveis, interferindo de forma efetiva na definição da obra pela escolha e atualização de um dos possíveis de sua aparição, enquanto o primeiro revela uma relação monológica em que o receptor apenas aciona o discurso do artista.

Em suma, por sua vocação para o dialogismo, AlterEgo estrutura-se como aquele campo de possíveis e solicita do interator a mesma vocação ao lhe propor dois níveis que configuram diferentes desafios dialógicos.

\footnotetext{
${ }^{195}$ ECO, Umberto. As Formas do Conteúdo. São Paulo, Perspectiva/Edusp, 1974 (tradução: Pérola de Carvalho), p. 126

196 Tavares, Monica. A Recepção no Contexto das Poéticas Interativas, S.Paulo, SP. Tese de Doutorado ECAUSP. 2000, p.98
} 


\subsection{1. - $1^{\mathrm{O}}$ NíveL: ANTI-EFEITO DE LiBERDADE}

Estruturado como hipermídia ${ }^{197}$, o primeiro nível da obra oferece escolhas, alternativas, viabilizando-se um trajeto, um percurso que se configura como obra personalizada em função das opções acionadas pelo interator (fig.ALT-01 a 06). Apresentando-se como aquele ambiente psicológico, a interface de AlterEgo é "interna ao evento"198, não apresentando barras de menu visíveis para a navegação: é tão somente o próprio auto-retrato que se mostra sensível ao cursor.

A pesquisa das fontes tipográficas para a inserção do texto verbal nos auto-retratos propôs-se na intenção de iconizar o signo simbólico, apresentá-lo naquela condição de Poesia Concreta em que "o ícone invade o corpo verbal"199, ciente das palavras de Décio Pignatari:

“o código verbal escrito apresenta padrões de semelhanças próprios, muitas vezes completamente desvinculados dos sons que pretende representar (por exemplo, bdqp ou BDQP); percebemos aqui uma linguagem quase autônoma, com problemas semióticos particulares na poesia moderna e na comunicação (iconização do código verbal escrito)."

Nesse sentido, a iconização de ego e alter-ego através da tipografia mostra que

$$
\text { ego é diferente de }
$$

tanto quanto

alter-ego é diferente de alter-ego.

${ }^{197}$ LANDOW, George P. The Definition of Hypertext and Its History as a Concept. http://www.cyberartsweb.org/cpace/ht/jhup/history.html Hipertexto, cunhado por Theodor H. Nelson nos anos 60 como escrita não seqüencial, oferece escolhas e diferentes percursos para o leitor numa tela interativa. Para Landow, "hipertexto denota um meio de informação que conecta informação verbal e não-verbal". Assim, o autor não faz distinção entre hipertexto e hipermídia. Neste trabalho, os termos são empregados nessa mesma perspectiva, de acordo com a premissa de um campo intertextual na imagem interativa.

${ }^{198}$ WeIsSBerg, Jean-Louis. "Interactivité et interface” In: Présences à Distance. Chapitre V - Retour sur interactivité. [http://hypermedia.univ-paris8.fr/weissberg/presence.htm]

${ }^{199}$ PignATARI, Décio. Semiótica e Literatura (Icônico e Verbal, Oriente e Ocidente). São Paulo, Ed. Cortez \& Moraes, 2. ${ }^{a}$ edição, 1979, p.121

${ }^{200}$ Pignatari, Décio. Semiótica e Literatura (Icônico e Verbal, Oriente e Ocidente). São Paulo, Ed. Cortez \& Moraes, 2. ${ }^{\text {a }}$ edição, 1979, p.108 
Diante das diversas possibilidades, o método das associações foi aplicado no sentido de reconhecer a combinação mais adequada ao contexto da obra. As associações desse método podem se efetuar por similaridade ou por contigüidade. Visto que se almejava um reforço do icônico no simbólico, a aplicação do método ocorreu numa mescla de associação por similaridade e por contigüidade tal como compreendida por Décio Pignatari: para o poeta concreto, "nada impede que as associações por similaridade [...] e as associações por contigüidade [...] se mesclem no desenvolvimento da criação" ${ }^{201}$ artística.

Assim, a imagem inicial apresenta um torso com a palavra "ego" que propõe a imagem como avatar para o "eu" do espectador. Ao toque do cursor, o mesmo torso reverte, exibindo a palavra "alter". O auto-retrato revela assim uma aglutinação de ego e alter-ego como duas faces de uma mesma imagem ou, neste caso, de uma mesma identidade. A separação somente se efetivará com o primeiro clique, que a bifurca em duas imagens solarizadas, lançando "alter" para um extremo e "ego" para o outro extremo do monitor. A partir de então, e somente então, o interator escolhe entre ego e alter-ego que, apesar da bifurcação, não se destituem de sua face complementar, persistindo e se mostrando alternadamente ao toque do cursor.

Tendo em conta que as práticas comunicacionais interativas se desenvolvem “dans une durée qui n'est plus programmée par un flux indépendant des acteurs, mais qui dépend du jeu de l'interaction" ${ }^{\text {202 }}$; em AlterEgo, a iconização progressiva da imagem intenta prolongar a recepção, no sentido de desautomatizar a percepção do interator e, sobretudo, de também

\footnotetext{
${ }^{201}$ PlazA, Julio \& Tavares, MoniCA. Processos Criativos com os Meios Eletrônicos: Poéticas Digitais. São Paulo, SP, editora Hucitec, 1998, p.101

${ }^{202}$ WeISSBERG, Jean-Louis. "Les Paradoxes de la Téléinformatique” In: Présences à Distance. [http://hypermedia.univ-paris8.fr/weissberg/presence.htm] Segue tradução: "num intervalo que não é mais programado por um fluxo independente dos atores, mas que depende do jogo da interação". (t.a.)
} 
$\underline{\text { desautomatizar a sua ação }}^{203}$, desacelerando-a ou procurando dificultar sua aceleração, ciente de que do outro lado encontra-se "une toute autre logique, celle de la temporalité humaine de saisie, de questionnement, parfois de doute, de décision et finalement d'action"204. A figura do receptor - ao exercer o seu tempo de absorver a informação, processá-la mentalmente, fazer as escolhas, ter dúvidas etc. - relativiza todo o regime temporal exatamente porque sua ação depende de uma interpretação. Com esse procedimento, intensifica-se o caráter dialógico da obra, pois o que AlterEgo está propondo, enquanto integrante de uma série como Auto-Retrato Coletivo, não é a mera reiteração do repertório do artista, mas sim um confronto de repertórios que possam se dialogizar na perspectiva de se instaurar uma consciência crítica.

AlterEgo propõe uma interatividade que intensifica (e tensiona) a relação dialógica entre o interator e o programa. Nesse tipo de interatividade, em que as atualizações se dão com alternativas limitadas, a tendência geral é ocultar ou dissimular essa limitação ao receptor. Tavares, referindo-se ao conceito de Lippmann, comenta que, "para simular uma liberdade de diálogo e assim camuflar esse limite, o artista propõe e constrói o chamado 'efeito de liberdade’ „205, empregando vários recursos, entre os quais a sugestão de um número crescente de opções e combinações, numa analogia à comunicação interpessoal.

Uma vez que esse efeito oculta um monologismo disfarçado em dialogismo, tal procedimento não é desejado em AlterEgo mas deliberadamente aplicado às avessas. A perspectiva crítica desta obra em particular solicitou um contraponto que se poderia

\footnotetext{
${ }^{203}$ Estabeleço aqui uma analogia ao procedimento de estranheza de Chklovski que mencionei no Cap.1 desta pesquisa, a respeito do ensaio Auto-Objeto. A reflexão de Ckhlovski em questão pode ser encontrada em: ChKLovski, V. "A Arte como Procedimento" in: Toledo, Dionisio de Oliveira (org.). Teoria da Literatura: Formalistas Russos. Porto Alegre, ed. Globo, $1^{\mathrm{a}}$ ed. 1973

${ }^{204}$ Weissberg, Jean-Louis. "Les Paradoxes de la Téléinformatique" In: Présences à Distance. [http://hypermedia.univ-paris8.fr/weissberg/presence.htm] Segue tradução: "uma outra lógica bem diferente, aquela da temporalidade humana de compreensão, de questionamento, às vezes de dúvida, de decisão e finalmente de ação". (t.a.)

${ }^{205}$ TAVAres, Monica. A Recepção no Contexto das Poéticas Interativas, S.Paulo, SP. Tese de Doutorado ECAUSP. 2000 , p.117
} 
denominar um "anti-efeito de liberdade", que anuncia a finitude de possibilidades, sempre apresentadas duas a duas, no cruzamento com a finitude do percurso, revelada pelo progressivo reposicionamento das imagens em direção ao centro do monitor, semelhante a uma contagem regressiva. Intensifica-se a presença autoral a contrapelo das possíveis escolhas do interator, instaurando uma reflexão crítica no embate com a coercividade da hipermídia, que me interessa enquanto elemento representativo da coerção social sobre a consciência do indivíduo.

A estrutura em hipermídia, que apresenta as escolhas sempre duas a duas seguindo a questão dialética/dialógica da proposta, não delimita o campo de possíveis na configuração da obra. Uma organização singular será realizada pelo internauta, através de sua ação. Vale lembrar que "no processo de recepção, não desaparece o discurso seqüencial e linear do horizonte dos desejos do spect-acteur ao explicitar, pelas suas escolhas subjetivas, a sua montagem textual, que expressa sua intencionalidade, ou melhor, uma alteridade constituída"206 . Estabelecendo uma comparação entre AlterEgo e Auto-Objeto, constata-se neste a não-seqüencialidade efetivamente construída e concretizada visualmente pelo artista.

Como apontado por Tavares,

"na obra difícil e na obra em movimento, esse campo de possíveis a ser explorado já se mostrava delimitado na própria configuração da obra. O mesmo ocorre na obra interativa, contudo, neste caso, o receptor dificilmente terá a definitude do universo de possibilidades que a ele está disponível. Ou seja: a obra é antes de tudo uma matriz virtual e operacional, e por isso mesmo tende a apresentar-se potencialmente infinita",207.

Em AlterEgo, o interator não visualiza a totalidade do campo de possíveis da obra, pois não há nesse caso a imediatez do conjunto que se observa, por exemplo, nos painéis de

\footnotetext{
${ }^{206}$ TAVAres, Monica. A Recepção no Contexto das Poéticas Interativas, S.Paulo, SP. Tese de Doutorado ECAUSP. 2000, p.139

207 TAVAres, Monica. A Recepção no Contexto das Poéticas Interativas, S.Paulo, SP. Tese de Doutorado ECAUSP. 2000, p.100 (grifo nosso)
} 
Auto-Objeto. A diferença fundamental reside no fato de que, em AlterEgo, "une portion seule

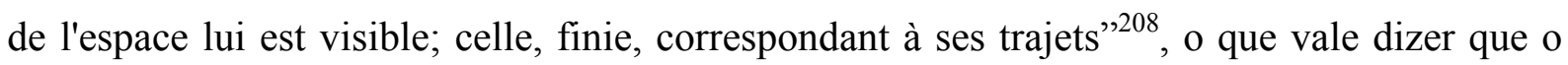
processo dialógico instaurado resulta num discurso aparentemente monológico do interator. Entretanto, esse trajeto singular é híbrido, colhido no campo dos possíveis proposto pelo artista, configurando assim a obra.

No processo de escolhas, a imagem recusada sofre deteriorações que transitam do código fotográfico ao informático, desde a negativação, a granulação até o pixalate, o nível máximo de iconização aplicado à imagem recusada. Esse processo de iconização sugere, em paralelo, uma desconstrução da identificação, enquanto a imagem indicada e selecionada permanece intacta. Nesse caso, configura-se uma relação aparentemente indireta entre a ação do interator e a desconstrução das imagens recusadas. Entretanto, a dialética ego/alter-ego se efetiva com a alternância das imagens sensíveis ao cursor que informam o grau de desconstrução que se realizará sobre a imagem não escolhida. O que vale dizer que a desconstrução ocorre dialogicamente, motivada por uma ação consciente dos efeitos de sua escolha. Entretanto, a escolha se revela ao final como um jogo de imposições ocultas nas alternativas: jogo que constrange o spect-acteur, instigando-o a refletir, ao final, sobre a representatividade, para si, do resultado obtido.

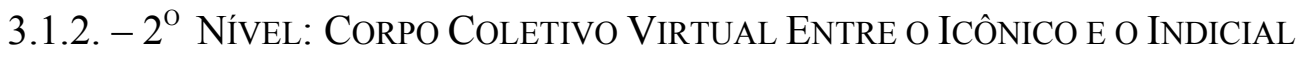

Explorando artisticamente a noção de caminho, percurso e busca, a estrutura hipermidiática do primeiro nível conduz o internauta ao segundo, onde se encontram recursos

\footnotetext{
${ }^{208}$ WeIssberg, Jean-Louis. "Les Paradoxes de la Téléinformatique” In: Présences à Distance.

[http://hypermedia.univ-paris8.fr/weissberg/presence.htm] Segue tradução: "uma única porção do espaço lhe é visível; aquela, finita, correspondente aos seus trajetos". (t.a.)
} 
que lhe permitem distorcer a imagem, num compromisso ético consigo mesmo no sentido de afirmar ou negar o resultado do percurso traçado.

Jogo de liberdades: o internauta pode agora intervir reiteradamente na imagem fotográfica como também, apenas com o clicar da tecla "RESTORE", desfazer as alterações realizadas e recuperá-la. Uma vez que os dados estão registrados em cadeias de pixels num contexto em que "não há mais suporte tangível - toda operação é reversível"209: Por esse aspecto, é possível experimentar diversas formas de interação, podendo reiniciar todo o processo sempre que desejar (fig.ALT-15 a 21).

As imagens interativas de AlterEgo categorizam-se pela predominância das funções conativa e poética da linguagem, por priorizarem as funções ligadas ao receptor e à obra. Recordemos contudo que não deixam de se relacionar às demais funções, uma vez que as imagens de AlterEgo revelam uma tendência para a função referencial e também metalingüística, posto que guardam elementos da fotografia que as gerou: a presença da moldura da foto original indicia que o referente pertence ao universo fotográfico e, portanto, a ação sobre a imagem corresponde também a um diálogo com essa linguagem. Nesse sentido, o formato original da foto digitalizada é o ponto de partida para intervenção; as anamorfias possíveis sobre a estrutura do auto-retrato se efetivam com o arrastar dos vértices da imagem pelo interator (fig.ALT-07 a 14).

As possibilidades de atuação sobre a imagem são pré-determinadas pelo programa e correspondem a uma recriação da obra, que somente acontece pela ação do receptor. Ao interagir, com recursos para distorcer o auto-retrato final a partir de seus vértices, esticando-o,

\footnotetext{
${ }^{209}$ FAVILLA, André. O signo híbrido: breves impressões em relação à síntese entre a informação fotográfica e a digital, s/d. acessado em 25/06/2003, [http://wawrwt.iar.unicamp.br/].
} 
invertendo-o, desdobrando-o em formas icônicas inesperadas geradas no processo mesmo da digitalização do seu gesto e da transformação (transição de formas) da imagem fotográfica, a noção de corpo-coletivo ${ }^{210}$, de Lygia Clark, atualiza-se em AlterEgo como um corpo coletivo virtual na medida em que o meu auto-retrato é submetido à interação que se opera sob uma matéria semiótica, numa presença à distância, que pela iteração dos diferentes interatores em rede atinge uma dimensão plural, coletiva.

Neste segundo nível, a prática receptiva se estabelece de uma forma híbrida, na medida em que a imagem de sobreimpressão fotográfica está subordinada a um programa que permite distorcê-la, tanto no sentido de reforçar o indicial (fig.ALT-16), reconstituindo sua informação fotográfica, quanto no sentido de reforçar o icônico (fig.ALT-19), conduzindo a imagem a uma configuração abstrata. Nesse sentido, a prática receptiva pode reiterar uma iconização semelhante à desenvolvida nos auto-retratos do ensaio Auto-Objeto (cf. Cap.1). Desta vez, contudo, tal possibilidade, embora prevista pelo artista, somente é trazida à obra pela ação do espectador, constituindo-se como resultado de uma hibridização de discursos e linguagens, aqui correlacionada a uma das categorias básicas da linguagem narrativa elucidadas por Bakhtin, para quem a hibridização "é a mistura de duas linguagens sociais no interior de um único enunciado, é o reencontro na arena deste enunciado de duas consciências lingüísticas”211. Para prosseguir esta reflexão, é necessário estabelecer a correlação autor/personagem e autor/espectador tendo em mente a postura de Dostoievski em relação ao seu herói, tal como descrito por Bakhtin:

"Le héros intéresse Dostoïevski, non pas en tant que phénomène dans la réalité, possédant des traits caractérologiques et sociologiques nettement définis, ni en tant qu'image déterminée, composée d'éléments objectifs à signification unique, répondant dans leur ensemble à la question 'qui est-il?'; le héros intéresse Dostoïevski comme point de vue

\footnotetext{
${ }^{210}$ CLARK, Lygia. Lygia Clark, Rio de Janeiro, edição Funarte, 1980, p.41

${ }^{211}$ Bakhtin, Mikhail. Questões de Literatura e de Estética (A Teoria do Romance), SP, Ed.Unesp, $4^{\mathrm{a}}$ ed, 1998. p.156.
} 
particulier sur le monde et sur lui-même, comme la position de l'homme cherchant la raison d'être et la valeur de la réalité environnante et de sa propre personne."212

Nesse sentido, a modalidade de hibridização que se efetiva no processo interativo proposto em AlterEgo constitui-se numa hibridização de pontos de vista, através das linguagens em curso. Trata-se de um híbrido que se dialogiza interiormente: os pontos de vista sócio-lingüísticos não se fundem "mas se justapõem dialogicamente" não podendo ser levados "até o diálogo individual, sensato, acabado e nítido"213, mantendo-se sempre em aberto, posto que não há uma resposta conclusiva para encerrar a sessão.

Na imagem interativa, constata-se um potencial para alterar a relação sujeito-imagemobjeto, hibridizando-os. Segundo Couchot, na figuração ótica, a topologia do Sujeito, do Objeto e da Imagem estabelecia uma "posição de confronto"214 entre os três termos. Com o advento da figuração digital, a hibridação sujeito-imagem-objeto se efetiva num grau de interdependências em que "a imagem interativa é o resultado da ação do observador sobre a imagem"215. No contexto artístico de AlterEgo, sendo a imagem em questão o meu autoretrato interativo, efetiva-se uma hibridação de identidades e pontos de vista, num exercício de alteridades, na perspectiva da "simulação do outro" proposta por Weissberg ${ }^{216}$, em que as possibilidades de iconização e indicialização da imagem encaminham, no primeiro caso, para

\footnotetext{
${ }^{212}$ BAKHTIN, Mikhail. La Poétique de Dostö̈evski, édition du Seuil, 1970. p.82 Segue Tradução: “O herói interessa a Dostoiévski, não enquanto fenômeno na realidade, possuindo traços caracterológicos e sociológicos nitidamente definidos, nem enquanto imagem determinada, composta de elementos objetivos com significação única, respondendo em seu conjunto à questão 'quem é ele?'; o herói interessa a Dostoiévski como ponto de vista particular sobre o mundo e sobre si mesmo, como a posição do homem procurando a razão de ser e o valor da realidade em torno e de sua própria pessoa." (t.a. )

${ }^{213}$ BAKHTIn, Mikhail. Questões de Literatura e de Estética (A Teoria do Romance), S.Paulo, Ed.Unesp, $4^{\mathrm{a}}$ ed, 1998. p. 158

${ }^{214}$ COUCHOT, Edmond. "Da Representação à Simulação: Evolução das Técnicas e das Artes da Figuração”. In: Parente, André (org.) Imagem-Máquina: A Era das Tecnologias do Virtual, RJ, Ed. 34, 1993, p.44

${ }^{215}$ COUCHOT, Edmond. "Da Representação à Simulação: Evolução das Técnicas e das Artes da Figuração". In: Parente, André (org.) Imagem-Máquina: A Era das Tecnologias do Virtual, R.J., Ed. 34, 1993, p.46

${ }^{216}$ Weissberg, Jean-Louis. "Les Paradoxes de la Téléinformatique” In: Présences à Distance. Chapitre VRetour sur interactivité. [http://hypermedia.univ-paris8.fr/weissberg/presence.htm]
} 
a não-representação e, no segundo caso, para a recuperação da informação fotográfica ou sua também possível distorção anamórfica.

O spect-acteur atua sobre essa matriz digital, esse corpo-coletivo virtual aberto a manipulações. Nesse momento, a condição de fake picture ${ }^{217}$ do auto-retrato interativo de AlterEgo é explorada artisticamente como elemento propício para a interatividade: o interator efetivamente explora as possibilidades desse fake picture aqui instaurado como um fake identity, uma falsa consciência de identidade social que, no contexto crítico da série, está aqui submetido às intervenções e subversões do indivíduo. Nesse sentido, no paradigma pósfotográfico ${ }^{218} \mathrm{em}$ que está imerso, o interator discute a natureza da própria fotografia (mais especificamente a fotografia de identificação social) ao interagir com o auto-retrato interativo de AlterEgo na medida em que a "possibilidade de sua manipulação deixa de ser periférica e passa a ser um assunto central" ${ }^{\text {219 }}$, aqui conduzido pelo próprio interator, não mais no âmbito da produção mas da recepção. Nesse sentido, numa licença poética, pode-se dizer que o espectador é convidado a dialogar com os elementos sócio-históricos de sua identidade no próprio bojo da "falsa consciência" identitária, encontrando na abstração e nas anamorfias uma oportunidade de questionar sua representação simbólica.

Contudo, todo o "acontecimento" é efêmero em seu profundo grau de privacidade: a obra não grava as intervenções do internauta. Ao findar a sessão, as imagens apagam-se no ambiente psicológico do monitor, retornando à sua condição virtual. Toda a experiência de "simulação do outro" que se vivencia em AlterEgo permanece em aberto na mente, na memória e na consciência do spect-acteur.

\footnotetext{
${ }^{217}$ MACHADO, Arlindo. Máquina e Imaginário: o desafio das poéticas tecnológicas, SP, Edusp, $1^{\mathrm{a}} / 2^{\mathrm{a}}$ ed.1993/1996, p.54

${ }^{218}$ SANTAELLA, Lúcia e NÖTH, W. Imagem: cognição, semiótica, mídia. SP, Iluminuras, 2a ed. 1999, p.166

${ }^{219}$ FADON, Carlos apud SANTAELLA \& NÖTH. Imagem: cognição,semiótica, mídia.Iluminuras, $2^{\mathrm{a} e d .1999, p .185}$
} 


\title{
3.2. ANDROMAQUIA $O_{N-L I N E}{ }^{220}$ : IDENTIDADES POLÍtICAS.
}

\author{
"Coletivo não é necessariamente sinônimo \\ de maciço e uniforme." \\ "A inteligência coletiva \\ constitui mais um campo de problemas \\ do que uma solução. Todos reconhecem \\ que o melhor uso que podemos fazer do ciberespaço \\ é colocar em sinergia os saberes, \\ as imaginações, as energias espirituais \\ daqueles que estão conectados a ele. "221
}

Pierre Lévy

Inaugurada na Virada Cultural SP 2006, ANDROMAQUIA On-Line (fig.ANDR-01 a 12) foi exibida na exposição CYBER-ARTE, com obras de Regina Silveira, Carmela Gross, Julio Plaza e Agnus Valente, permanecendo disponível no meu site oficial [nardogermano.com]. O título desta obra interativa origina-se num jogo de linguagem com meu próprio nome, sugerindo, no encontro anagramático Nardo/Andro, o possível trânsito entre o indivíduo e o coletivo proposto no programa artístico da série Auto-Retrato Coletivo.

Esta obra é um desdobramento da instalação participativa Cabeça Defronte, realizada no Complexo Argos em 2003. É composta por imagens digitalizadas das colagens de fotos para documentos da Fotomática com recortes de jornal (manchetes, textos e fotos), realizadas em 1987. Reapresenta-se, assim, o contexto original da série como interface inicial para a intervenção dos internautas.

\footnotetext{
${ }^{220}$ ANDROMAQUIA On-Line é um auto-retrato interativo com o tema "Auto-Retrato Coletivo e Ideologia". A obra foi produzida entre 2004/2006 e inaugurada em 20 de maio, na Virada Cultural SP 2006.

${ }^{221}$ LÉvy, Pierre. A Inteligência Coletiva: por uma antropologia do ciberespaço, S Paulo-SP, Ed. Loyola, $4^{\mathrm{a}}$ edição 2003, p.66 e LÉVY, Pierre. Cibercultura, São Paulo-SP, Ed. 34, 1999, p.130
} 


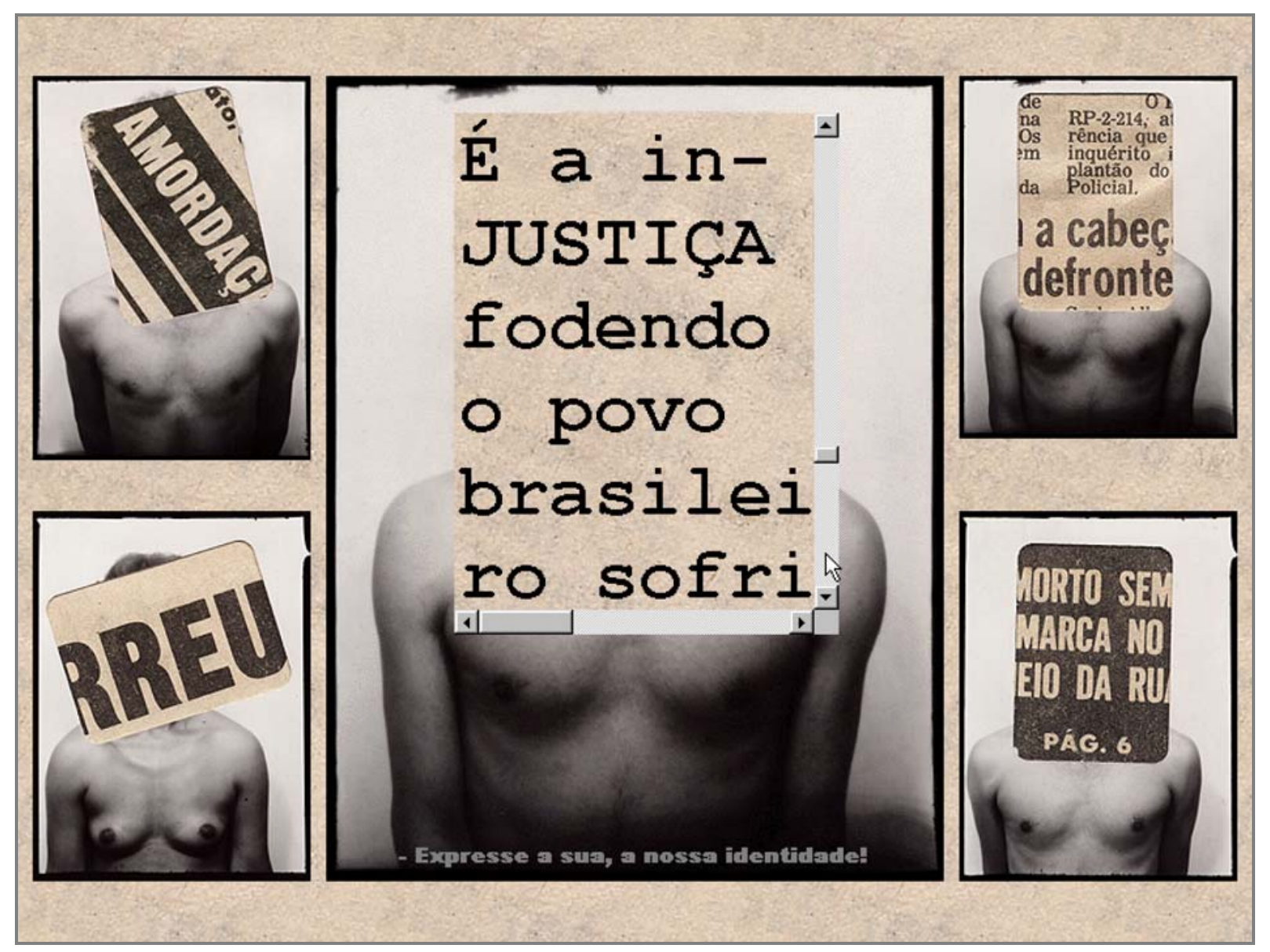

FIG. ANDR-01 - ANDROMAQUIA On-Line, 2004-2006 - Nardo Germano. http://www.nardogermano.com/autoretratocoletivo/andromaquiaonline 


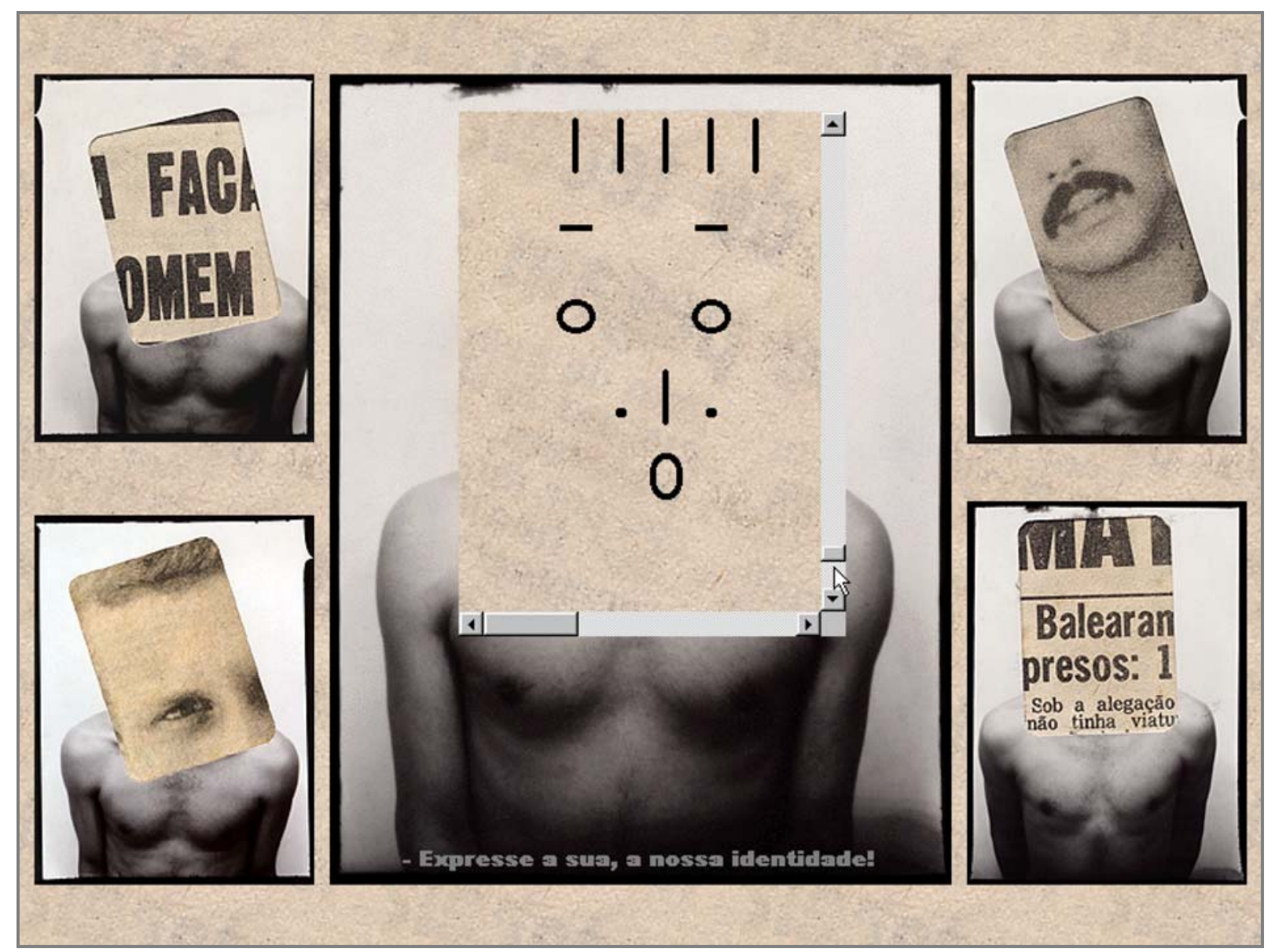

FIG. ANDR-02 - ANDROMAQUIA On-Line, 2004-2006 - Nardo Germano. http://www.nardogermano.com/autoretratocoletivo/andromaquiaonline 


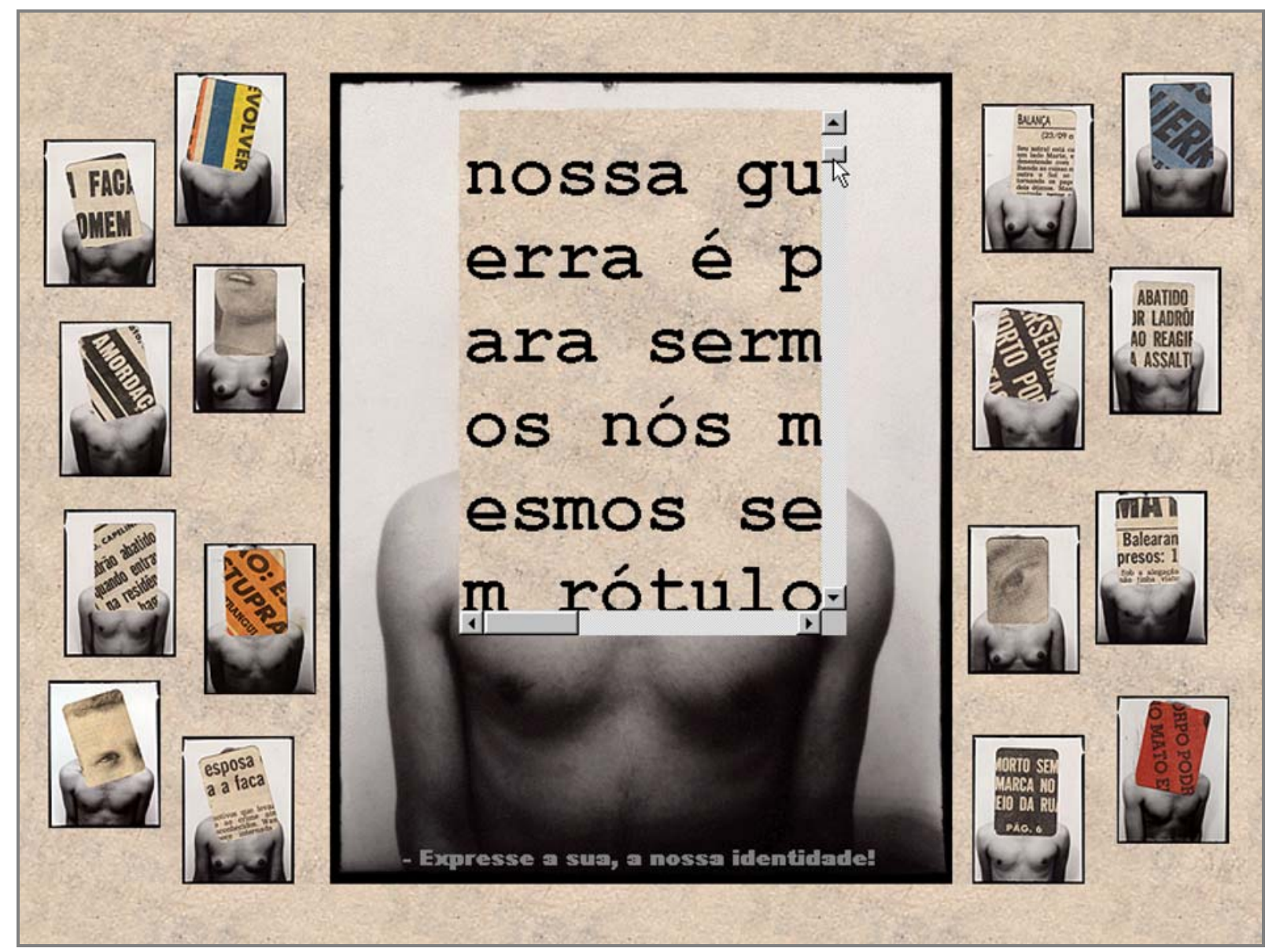

FIG. ANDR-03 - ANDROMAQUIA On-Line, 2004-2006 - Nardo Germano. http://www.nardogermano.com/autoretratocoletivo/andromaquiaonline 

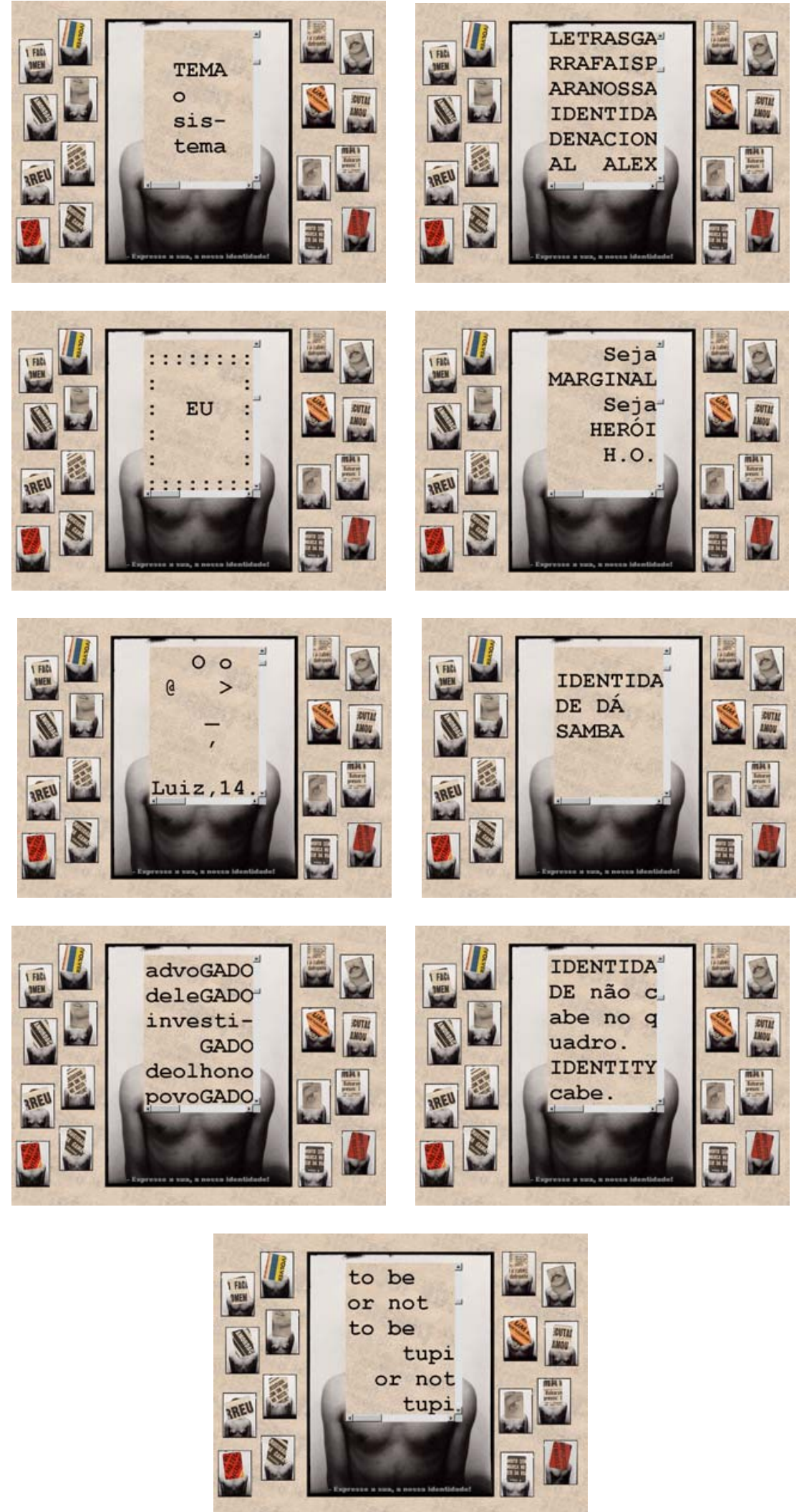

FIG. ANDR-04 a 12 - ANDROMAQUIA On-Line, 2004-2006 - Nardo Germano: alografia plural. http://www.nardogermano.com/autoretratocoletivo/andromaquiaonline 
O ambiente criado remete à diagramação das mídias jornalísticas, tendo como plano de fundo uma textura de papel jornal sobre a qual dispõem-se as colagens digitalizadas da série. Equacionando a estrutura guttemberguiana para um "direito de resposta" on-line, a obra convida o interator a se expressar nessa diagramação, no campo de formulário de opinião em aberto no recorte vazado do meu auto-retrato acéfalo, onde se inscrevem, sob o mesmo plano de fundo em papel jornal, os caracteres alográficos das intervenções dos interatores. O esquema de comunicação em estrela um/todos, majoritariamente praticado pelas mídias impressas, é substituído pelo esquema em espaço todos/todos do ciberespaço ${ }^{222}$, aplicando em certa medida "o indispensável desvio técnico para atingir a inteligência coletiva" 223 em prol da construção de uma alografia plural ${ }^{224}$.

A abertura dialógica on-line propõe-se a explorar artisticamente a interface interativa, transpondo o contexto do formulário de envio de dados para a constituição do meu autoretrato acéfalo numa potencial "cabeça coletiva", um repositório ideológico para a polifonia a ser construída com o acréscimo das contribuições dos interatores que metaforicamente erigem uma cabeça pensante alimentada pelos discursos dialógicos em confronto.

ANDROMAQUIA On-Line divide-se em três momentos, que articulam diferentes papéis para o internauta desempenhar em sua interação com a obra.

\footnotetext{
${ }^{222}$ Pierre Lévy aponta essa distinção entre o telefone e a TV, um/um e um/todos, respectivamente, em oposição às possibilidades do ciberespaço, como dispositivo de comunicação estruturado pelo esquema em espaço todos/todos. Essa comparação parece-me igualmente válida em relação à imprensa. Vide: LÉVY, Pierre. $A$ Inteligência Coletiva: por uma antropologia do ciberespaço, São Paulo, Ed. Loyola, $4^{\mathrm{a}}$ ed, 2003, p.63-64 ${ }^{223}$ LÉvY, Pierre. Cibercultura, São Paulo-SP, Ed. 34, 1999, p.130

${ }^{224}$ A noção de alografia plural guarda uma analogia ao que Genette formula como uma autografia plural por iteração, vide. GENETTE, Gérard. L'Oeuvre de l'Art: immanence et transcendence Paris, Éditions du Seuil, 1994. p.84.
} 


\subsection{1. - $1^{\mathrm{O}}$ MOMENTO: EXERCÍCIO DiALÓGICO NO CONTEXTO DO OUTRO}

O primeiro momento de $A N D R O M A Q U I A$ On-Line efetiva-se pela exibição atualizada da "cabeça coletiva" com as intervenções até então enviadas pelos interatores. Conferindo visibilidade à contribuição mais recente, a obra propõe inicialmente uma exploração dialógica a ser realizada pelo interator, através do acionamento da barra de rolagem, para poder acessar as demais contribuições.

Recordando que os graus de abertura incorporam os graus anteriores ${ }^{225}$, apresenta-se um contexto que, numa abertura de $1^{\circ}$ grau, instaura as condições preliminares para reflexão e interpretação do internauta, no intuito de criar estímulos para uma interação mais efetiva e reflexionante na fase seguinte (como se verá mais adiante). Sob o princípio de uma Poética do Estranhamento $^{226}$, a exibição dos textos, realizada com o deslizar da barra de rolagem, foi estabelecida na cronologia inversa de envio de dados pelos interatores. Desse modo, as réplicas antecedem o discurso do outro, criando zonas de ambigüidades e descontextualizações que intentam desautomatizar e/ou aguçar a percepção para uma "recepção ativa do discurso de outrem" - fator que, segundo Bakhtin, "é fundamental também para o diálogo" 227 que, neste caso, está previsto enquanto fluxo de alteridades.

Além disso, na articulação desse possível diálogo entre as contribuições, destaca-se um procedimento condizente com a Poética da Sugestão, implementado "na intenção de

\footnotetext{
${ }^{225}$ PlAZA, Julio. Arte e Interatividade: autor-obra-recepção, 2000, p.10 Acessado em 25/06/2003, [http://www.plural.com.br/jplaza/texto01.htm].

${ }^{226}$ ChKLOVSKI, V. "A Arte como Procedimento" in: TOLEDO, Dionisio de Oliveira (org.). Teoria da Literatura: Formalistas Russos. Porto Alegre, ed. Globo, $1^{\text {a }}$ ed. 1973

${ }^{227}$ BAKhtin, Mikhail. Marxismo e Filosofia da Linguagem São Paulo, Hucitec, 6a edição, 1992 p. 146

(Tradução: Michel Lahud e Yara Frateschi Vieira)
} 
perturbar o princípio de linearidade da linguagem,"228, enfatizando assim o canal da mensagem: Os diálogos intercalados, normalmente gerados por esse tipo de formulário, foram adotados como mecanismo em potencial para "exercitar a habilidade decodificadora do receptor",229 na medida em que "os procedimentos não organizam as normas do repertório e os segmentos das perspectivas em uma seqüência previsível”, rompendo-se assim o "princípio da good continuation, pré-requisito dos atos diários de percepção" ${ }^{, 230}$ aos quais o receptor está habituado. Destaca-se assim “a relevância estética dos vazios"231 que o internauta é estimulado a fechar pela interpretação ${ }^{232}$, para lograr compreender o encadeamento dos diálogos alternados que compõem a “cabeça coletiva”, organizando-os mentalmente.

Paralelamente, as colagens digitalizadas dispõem-se na interface da obra em estrutura hipermidiática, numa abertura de $3^{\circ}$ grau, de modo que o interator reorganize as combinações no monitor, entre o indivíduo e o coletivo, entre o masculino e o feminino, entre o verbal e o visual... Aqui, instado pelo jogo permutatório, o interator pode recombinar os sentidos que definem a obra pela atualização dialógica do campo de possíveis circunscrito pelo artista.

Neste primeiro momento interativo de ANDROMAQUIA On-Line, a Poética da Ação, na acepção de Tavares, engendra-se de modo que "o receptor é muito mais construtor das

\footnotetext{
${ }^{228}$ TAVARES, Monica. A Recepção no Contexto das Poéticas Interativas. S.Paulo, SP. Tese de Doutorado ECAUSP. 2000, p.51

${ }^{229}$ TAVAres, Monica. A Recepção no Contexto das Poéticas Interativas. S.Paulo, SP. Tese de Doutorado ECAUSP. 2000, p.50

${ }^{230}$ ISER, Wolfgang. “A Interação do Texto com o Leitor” in: LIMA, Luiz Costa (org.)A Literatura e o Leitor. R.Janeiro,Paz e Terra,1979,p.110

${ }^{231}$ ISER, Wolfgang. “A Interação do Texto com o Leitor” in: LIMA, Luiz Costa (org.)A Literatura e o Leitor. R.Janeiro, Paz e Terra,1979,p.89

${ }^{232}$ Neste caso específico, não considero a inversão da ordem cronológica como criadora de "vazios" a serem preenchidos, mas antes como instauradora de estranhamento pela descontextualização que provoca um dificultamento na recepção. Por outro lado, considero os diálogos intercalados como criadores de "vazios", e estes sim como sugestão (de acordo com Iser) enquanto "dificuldade de ideação" em "oposição ao critério de dificuldade da percepção" de Chklovski. ISER, Wolfgang. "A Interação do Texto com o Leitor" in: LIMA, Luiz Costa (org.)A Literatura e o Leitor.R.Janeiro,Paz e Terra,1979, p.112 e ChKlovski, V. "A Arte como Procedimento" in: Toledo, Dionisio de Oliveira (org.). Teoria da Literatura: Formalistas Russos. Porto Alegre, ed. Globo, $1^{\text {a }}$ ed. 1973. p.45
} 
possíveis ações do que dos sentidos possíveis da obra"233. Nessa perspectiva, acompanhando o pensamento de Pierre Lévy ${ }^{234}$, “o ato fundamental da recepção da obra torna-se a operação”, na medida em que coloca o interator numa posição em que ele "instancia uma matriz" virtual e operacional, atualizando-a a partir de sua multiplicidade pré-codificada; nessa condição, a ação e a responsabilidade do receptor na atualização da obra predominam sobre a busca de sentido da atividade hermenêutica: no campo dos possíveis da obra, "o sentido torna-se um possível, um objeto de primeira qualidade a partir de um poder de agir e decidir" do interator.

Pela prioridade conferida às escolhas nesta etapa da recepção interativa de ANDROMAQUIA On-Line, "o significado enquanto problema é que tende a desaparecer em proveito dos dilemas da ação" 235 do receptor. Sem, contudo, obliterar-se: a atualização ancora-se no pressuposto de que a ação do espectador esteja vinculada ao repertório do artista (e dos demais interatores...), “ao estoque de símbolos conhecidos e por ele atualizados que determinam sua competência e sua performance em decifrar códigos e articular significações por meio da operação de linguagens sobre linguagens" ${ }^{, 236}$, denotando que o espectador necessita mobilizar as significações da obra, interpretá-la, inteirar-se enfim das várias questões sobre Identidade Coletiva ali disponíveis para colocar-se no papel de interator. Ganha importância "a necessidade de ele apreender os significados da obra à medida que a constitui" enquanto consciência receptora na mediação com sua estrutura.

Apesar de, neste contexto permutatório, a Poética da Ação propor-se na perspectiva de mobilizar o interator na busca dos sentidos já previstos e/ou incluídos na obra, a minha expectativa é que a disposição desse spect-acteur não se limite a esta etapa. Interessa-me, como

\footnotetext{
${ }^{233}$ Tavares, Monica. A Recepção no Contexto das Poéticas Interativas. S.Paulo, SP. Tese de Doutorado ECAUSP. 2000, p.100

${ }^{234}$ LÉVy, Pierre. A Máquina Universo: criação, cognição e cultura informática, Porto Alegre, Ed. artmed, 1998, p.53-55

${ }^{235}$ LÉVY, Pierre. A Máquina Universo: criação, cognição e cultura informática, Porto Alegre, Ed. artmed, 1998, p.54

${ }^{236}$ TAVAres, Monica. "O Pacto de Leitura das Poéticas Interativas", in: Anual da Compós, 2004. p.6
} 
propositor, que, ao se esgotar o campo de possíveis ou o empenho em articular repertórios e discursos alheios, sobrevenha ao interator a necessidade de incluir o seu próprio repertório e o seu próprio discurso na "cabeça coletiva" metaforicamente configurada na obra.

\subsection{2. $-2^{\mathrm{O}}$ Momento: Identidade EM Poiesis : O SignificAdo ENQUANTo Problema}

Nesta $2^{\text {a }}$ etapa de ANDROMAQUIA On-Line, a estrutura hipermidiática das colagens digitalizadas, organizadas como campo de possíveis, permanece na interface da obra, porém passa a ser uma possibilidade periférica de interação, uma vez que o foco se desloca para o envio de dados a serem incorporados à obra.

Momento do indivíduo diante de uma cabeça vazia. No embate com a temática da obra, o internauta é solicitado a um posicionamento em relação aos temas envolvidos: identidade; vida e morte; violência; religiosidade; relações sociais e ideológicas. Esse novo papel que lhe é proposto inverte a relação anteriormente experimentada pelo interador: agora o significado enquanto problema toma corpo em relação aos dilemas da ação.

ANDROMAQUIA On-Line explora, neste segundo momento, a potencialidade do ciberespaço para a constituição de sujeitos coletivos de enunciação enquanto

"produtores de sintomas políticos vivos que permitiriam aos coletivos humanos inventar e exprimir de modo contínuo enunciados complexos, abrir o leque das singularidades e das divergências, sem por isso inscrever-se em formas fixadas de antemão" ${ }^{237}$.

\footnotetext{
${ }^{237}$ LÉVY, Pierre. A Inteligência Coletiva: por uma antropologia do ciberespaço, S.Paulo, Ed. Loyola, $4^{\mathrm{a}}$ ed. 2003, p.67
} 
Nesta conversão de aisthesis para poiesis, configura-se a possibilidade de o interator inserir sua identidade na obra, na medida em que "a experiência da aisthesis pode, por fim, se incluir no processo de uma formação estética da identidade, quando o leitor faz a sua atividade estética ser acompanhada pela reflexão sobre seu próprio devir”, sua própria biografia $^{238}$ que na atividade poética altera o objeto estético na "concretização de sua forma e de seu significado" ${ }^{, 239}$. Na perspectiva de viabilizar a manifestação de alteridades, as soluções poéticas acessíveis ao interator propõem-se no cruzamento do método dos limites, que privilegia o racional ${ }^{240}$, e do método experimental, de tentativas e erros, que privilegia os sentidos $^{241}$. Cabe ao interator enfrentar as regras não explicitadas na obra, entre o sensível e o inteligível, pelo espírito de descoberta e/ou pela capacidade para reconhecer estruturas. $\mathrm{O}$ campo do formulário (oito letras por linha, com fonte e tamanho padrão) cria condições para truncamentos e atomizações do texto, colocando elementos da Poética da Sugestão como uma das possibilidades de expressão do interator, na medida de sua capacidade de poiesis em articular este procedimento para expressar seu pensamento. Essa possibilidade, contudo, não impede a inclusão de textos analítico-discursivos, que podem alcançar a extensão que o interator necessitar para completar sua idéia. Do mesmo modo, explorando o campo de formulário e o código do teclado, o interator também pode compor símbolos e desenhos, numa intersemiose entre o verbal e o visual.

Intencionalmente, a programação do campo de formulário não exerce nenhum tipo de crítica sobre os dados enviados, resguardando "a autonomia e a abertura para a alteridade"242

\footnotetext{
${ }^{238}$ JAUSS, Hans Robert. "O Prazer Estético e as Experiências Fundamentais da Poiesis, Aisthesis e Katharsis" in: Lima, Luiz Costa (org.)A Literatura e o Leitor.R.Janeiro,Paz e Terra,1979,p.82

${ }^{239}$ JAUSS, Hans Robert. "O Prazer Estético e as Experiências Fundamentais da Poiesis, Aisthesis e Katharsis" in: Lima, Luiz Costa (org.)A Literatura e o Leitor.R.Janeiro,Paz e Terra,1979,p.82

${ }^{240}$ PlazA, Julio \& TAVAres, Monica. Processos Criativos com os Meios Eletrônicos: Poéticas Digitais. São Paulo, SP, editora Hucitec, 1998, p.97

${ }^{241}$ PlaZA, Julio \& TAVAres, Monica. Processos Criativos com os Meios Eletrônicos: Poéticas Digitais. São Paulo, SP, editora Hucitec, 1998, p.103

${ }^{242}$ LÉVY, Pierre. Cibercultura, São Paulo-SP, Ed. 34, 1999, p.132
} 
de modo que, sem censura ou discriminações valorativas, a obra incorpore automaticamente a ação do interator, a singularidade de sua solução e todos os elementos heteróclitos de sua contribuição, sejam textos, desenhos, símbolos - artísticos ou não -, numa proposta de [des]construção identitária "em coletividade" ${ }^{\text {"243 }}$. Estabelece-se, assim, a inclusão do ponto de vista individual na "cabeça coletiva", agregando novas significações, reforçando outras, questionando ou negando-as sem que as novas intervenções anulem as demais: não há como apagar nem atropelar ${ }^{244}$ a opinião do outro. Nesse sentido, o interator tem a oportunidade de manifestar-se em sua individualidade, ampliando progressivamente a qualidade polifônica da obra, no mesmo espírito de abertura à alteridade que lhe foi garantido.

ANDROMAQUIA On-Line não se impõe como entidade mantenedora de um discurso monológico e consensual, mas sim provedora de um discurso hibridizado, "dialogizado interiormente" 245 : uma “cabeça coletiva" necessariamente problematizadora por sua polifonia. Cabe ressaltar que a opção por oferecer "a uma coletividade o meio de proferir um discurso plural, sem passar por representantes, é o que está em jogo, do ponto de vista tecnopolítico"246, seja na proposição original de Auto-Retrato Coletivo ao questionar a construção identitária fundada no discurso monológico que massifica grupos sob estigmas

\footnotetext{
${ }^{243}$ WeIsSBERG, Jean-Louis. "Les Paradoxes de la Téléinformatique" In: Présences à Distance [http://hypermedia.univ-paris8.fr/weissberg/presence.htm] a expressão "em coletividade" é empregada aqui a partir do conceito de auteur en collectif (autor em coletividade) proposto por Weissberg: "Parallèlement à la systématisation de la coopération productive, plutôt qu'un évanouissement, cést bien une hypertrofie de la signature qui se propage. Le contexte de l'hypermédiation devrait plutôt inciter à penser un concept d'auteur en collectif (et non d'auteur collectif) qui dépasse la dénégation de l'individualité au profit d'un renforcement des deux pôles. Segue Tradução: "Paralelamente à sistematização da cooperação produtiva, mais do que um apagamento, é sobretudo uma hipertrofia da assinatura que se propaga. $\mathrm{O}$ contexto de hipermediação deveria acima de tudo incitar a pensar um conceito de autor em coletividade (e não de autor coletivo) que ultrapassa a recusa da individualidade em proveito de um reforço paralelo dos dois pólos." (t.a. )

244 "Atropelar" tem aqui o sentido de "sobrepor" textos, comprometendo sua legibilidade, como foi mencionado a respeito da participação em Corpo Coletivo, no Cap II.

${ }^{245}$ BAKHTIN, Mikhail. Questões de Literatura e de Estética (A Teoria do Romance), São Paulo, Ed.Unesp, $4^{\mathrm{a}}$ ed, 1998. p. 158

${ }^{246}$ LÉVY, Pierre. A Inteligência Coletiva: por uma antropologia do ciberespaço, S.Paulo, Ed. Loyola, $4^{\mathrm{a}}$ ed 2003, pp.65-66
} 
sociais, seja na proposição de abertura da obra ao espectador no sentido de redimensionar a minha presença autoral.

Se, num primeiro momento, o reconhecimento de um repertório comum viabiliza e qualifica o espectador para o papel de interator; neste segundo momento, o foco de meu interesse com esta obra enfatiza a inserção de repertórios trazidos do universo e da experiência de vida de cada um dos interatores em particular. A diversidade de pontos de vista e de formatividades pode assim configurar-se como identidades plurais em confronto - daí andromaquia (gr. "combate de homens"), na perspectiva de constituição on-line de identidades políticas, num exercício de cidadania. Nesse sentido,

"A identidade política dos cidadãos seria definida por sua contribuição à construção de uma paisagem política perpetuamente em movimento, e pelo apoio que dariam a determinados problemas (que eles julgam prioritários), a determinadas posições (às quais eles aderem), a determinados argumentos (que eles retomam por conta própria). Com isso, cada um teria uma identidade e um papel político absolutamente singulares e diferentes dos de outro cidadão, conservando a possibilidade de concordar com os que, sobre este ou aquele assunto, em determinado momento, possuem posições próximas ou complementares" ${ }^{247}$.

O instrumento desta andromaquia não é o poder da força bruta. Propõe-se o debate como princípio fundamental bakhtiniano de dialogismo e pluralidade de vozes que abre espaço para a coexistência das alteridades, com interpenetração e cruzamento de diferentes códigos, repertórios e discursos.

\footnotetext{
${ }^{247}$ LÉvY, Pierre. A Inteligência Coletiva: por uma antropologia do ciberespaço, São Paulo-SP, Ed. Loyola, $4^{\mathrm{a}}$ edição 2003, p.65
} 


\subsection{3. $-3^{\mathrm{O}}$ MOMENTO: INSTANTANEIDADE E INCLUSÃO}

Retomando os momentos anteriores, foi visto que no primeiro momento de ANDROMAQUIA On-Line, o internauta exerce um papel externo ao campo de debate da obra. Embora possa tomar uma posição crítica em relação à realidade ali representada pelas colagens digitais e intervenções dos demais interatores, o seu papel de interator se realiza num exercício dialógico de alteridade que aciona repertórios e discursos alheios. O segundo momento é alcançado somente pela conjunção de vontade e ação do interator para incluir o seu próprio discurso na obra e assim contribuir com novos sentidos. Deparando-se com a cabeça vazia, o interator é colocado diante do problema do significado, na posição de mobilizar e formular uma expressão própria de sua identidade.

Esses dois momentos tensionam aquela condição de spect-acteur, mencionada por Weissberg ${ }^{248}$ em que o processo de percepção, questionamento, dúvidas, tomada de decisão e ação fazem com que a lógica da temporalidade do internauta instaure uma relação dialógica com o regime temporal tecnológico, redimensionando a noção de instantaneidade do sistema. O interator enfrenta os dificultamentos que a obra impõe à própria fruição e interação, como a necessidade de organização dos sentidos no primeiro momento e a utilização do campo de formulário construído sob o princípio do método dos limites, no segundo.

No contexto da participação mediada instantaneamente, que garante "a ação e a reação, quase que simultaneamente, em tempo real" ${ }^{249}$ no processo de comunicação, este terceiro momento de ANDROMAQUIA On-Line concentra-se no imediato sentimento de

\footnotetext{
${ }^{248}$ WeIsSBerg, Jean-Louis. "Les Paradoxes de la Téléinformatique” In: Présences à Distance. [http://hypermedia.univ-paris8.fr/weissberg/presence.htm]

${ }^{249}$ TAVARES, Monica. A Recepção no Contexto das Poéticas Interativas. S.Paulo, SP. Tese de Doutorado ECAUSP. 2000, p.93
} 
inclusão que a obra se propõe a provocar no interator. Com a ação de teclar sobre o botão inclua-me, o sistema instantaneamente atualiza os dados e retorna à Cabeça Coletiva, com a nova intervenção já inserida junto às demais em exibição. Aqui, a importância do papel de spect-acteur: este momento de inclusão pela instantaneidade do sistema somente lhe será possível como resultado de seu esforço para ultrapassar os dois momentos anteriores da obra.

Nesta proposição, a instantaneidade do sistema é por mim acionada poeticamente visando a construir uma metáfora da inclusão. Inclusão, social e digital, da identidade do indivíduo no coletivo, numa perspectiva utópica ancorada no ideal de uma inteligência coletiva que, no meu ponto de vista, consiste em desafiá-lo como ser pensante. Nesse sentido, o princípio em pauta é o de "reconhecer que a diversidade das atividades humanas, $\underline{\text { sem }}$ $\underline{\text { nenhuma exclusão, }}$, pode e deve ser considerada, tratada, vivida como 'cultura' "250, o que projeta a obra no sentido de transformação da realidade identitária, na medida em que a inclusão do indivíduo que se promove aqui não privilegia a irracionalidade pressuposta no estigma da violência e da criminalidade.

A junção das noções de identidade, inclusão e racionalidade redimensionam a discussão da identidade numa perspectiva política na medida em que o indivíduo "entra em contato e compõe-se com outros cérebros, com sistemas de signos, de linguagens e de tecnologias intelectuais, participa de comunidades pensantes que exploram e criam mundos múltiplos" ${ }^{, 251}$. Criam-se assim condições potenciais nas quais o indivíduo "pluraliza sua identidade, explora mundos heterogêneos, é ele próprio heterogêneo e múltiplo, em devir, pensante" ${ }^{252}$. Uma vez que sua identidade pode ser traduzida em termos "de informação,

\footnotetext{
${ }^{250}$ LÉvY, Pierre. O que é o Virtual? São Paulo-SP, Ed. 34, 1996, p.120 (grifo meu).

${ }^{251}$ LÉVY, Pierre. A Inteligência Coletiva: por uma antropologia do ciberespaço, SPaulo-SP, Ed. Loyola, $4^{\mathrm{a}}$ ed 2003, p. 135

${ }^{252}$ LÉVY, Pierre. A Inteligência Coletiva: por uma antropologia do ciberespaço, SP,Ed.Loyola,4aed.2003,p.135
} 
rumo à extensão tecnológica da consciência” ${ }^{, 253}$, o interator expõe-se no contexto de alteridades dos formulários de opinião, submetido à crítica e à auto-crítica entre o Indivíduo e o Coletivo.

Em ANDROMAQUIA On-Line, a cada inclusão dos spect-acteurs, promove-se a expansão da série Auto-Retrato Coletivo para além do ponto de vista do autor, sem contudo apagá-lo nem promover a sua exclusão:

"De fato, o fiador da totalização da obra, ou seja, do fechamento de seu sentido, é o autor. Mesmo se o significado da obra se pretende aberto ou múltiplo, devemos ainda assim pressupor um autor se quisermos interpretar intenções, decodificar um projeto, uma expressão social ou mesmo um inconsciente. $\mathrm{O}$ autor é a condição de possibilidade de qualquer horizonte de sentido estável" ${ }^{\text {254 }}$.

Nessa perspectiva, o próprio autor Nardo Germano faz parte desta andromaquia, presença artisticamente já sugerida pelo anagrama "andro" no título da obra, como também na organização da estrutura hipemidiática que exibe as colagens digitais que carregam o ponto de vista de seu autor e também pela autoria do texto inaugural da "cabeça coletiva" que estabelece um diálogo intertextual com uma frase inscrita por um participante na instalação Cabeça Defronte (2003, fig.CBD-02).

$\mathbf{E U}$

NÃO

QUERO

$\mathbf{O}$

ESPEL

HO OH

\footnotetext{
${ }^{253}$ McLuhan, Marshall. Os Meios de Comunicação como Extensões do Homem (Understanding Media), S.Paulo, Ed.Cultrix, $5^{\text {a }}$ ed., 1979, (tradução: Décio Pignatari) p.23

${ }^{254}$ LÉVY, Pierre. Cibercultura, São Paulo-SP, Ed. 34, 1999, p.147
} 
Assim, configura-se dialeticamente a presença de um auteur en collectif "qui dépasse

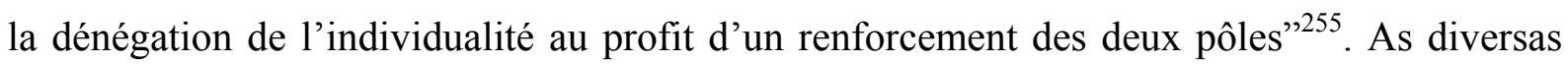
contribuições gravitam em torno da proposição artística instaurada e, a cada atualização, ampliam-se e renovam-se, numa "coproduction de sens"256 on-line.

Em ANDROMAQUIA On-Line, a inclusão de autor e interatores na obra, pela ênfase aqui atribuída à esfera do saber, é fator de grande relevância enquanto possibilidade de conquista e exercício de níveis de alteridade e de consciência, como também conscientização de si mesmo e de sua identificação a grupos e coletividades.

\footnotetext{
${ }^{255}$ WeISSBERG, Jean-Louis. "Les Paradoxes de la Téléinformatique” In: Présences à Distance. [http://hypermedia.univ-paris8.fr/weissberg/presence.htm] Tradução: autor em coletividade "que ultrapassa/supera a recusa da individualidade em proveito de um reforço paralelo dos dois pólos.” (t.a.)

${ }^{256}$ Forest, Fred. Pour un Art Actuel - L'art à l'heure d'Internet. Paris, L'Harmattan, 1998, p.130. Segue tradução: "co-produção de sentidos".
} 


\subsection{Give Me Your FaCe ${ }^{257}$ : Identidades Metonímicas}

Em Give me your Face/Doe seu Rosto, o espectador é convidado a se auto-retratar, fotografando a parte do rosto com a qual mais se identifica, para doar ao Auto-Retrato Coletivo. A proposta é realizar uma colagem digital numa composição de tom surrealista, encaixando o auto-retrato do participante ou interator no meu auto-retrato acéfalo, adotado como torso comum para todas as colagens que compõem a obra. Instaura-se um contraponto às colagens de Sujeitos (cf. Cap.1), cujos recortes de jornal exibem parcialmente os rostos publicados como matéria sensacionalista, na medida em que a proposição busca suplantar o elemento trágico com um exercício ontológico de auto-afirmação.

Realiza-se uma abertura ao espectador tanto em nível de participação como de interatividade, com predominância para a noção de abertura de $3^{\circ}$ grau na medida em que ambas proposições têm o foco centrado na relação com o registro fotográfico a ser obtido digitalmente: com câmera fotográfica digital ou webcam.

Optei, contudo, pela dupla proposição de abertura ao espectador para esta obra tendo em vista a ênfase especial dada à performance corporal no ato de posar para o auto-retrato. Nesse sentido, considerando que os graus de abertura não são substitutivos, mas comportam os anteriores ${ }^{258}$, desdobrei-os poeticamente na mesma obra, reiterando com esse procedimento que não existem hierarquias, valorações ou antagonismos em relação aos diferentes graus de abertura, mas sim possibilidades poéticas que podem contribuir em conjunto para a realização de um projeto.

\footnotetext{
${ }^{257}$ Give Me Your Face é um auto-retrato simultaneamente participativo e interativo que desenvolve o tema "Identidades Híbridas no Auto-Retrato". Essa obra foi concebida em 2001 e apresentada pela primeira vez em 2003, permanecendo disponível no site oficial www.nardogermano.com ).

${ }^{258}$ PlazA, Julio. Arte e Interatividade: autor-obra-recepção, 2000 Acessado em 25/06/2003, [http://www.plural.com.br/jplaza/texto01.htm]
} 

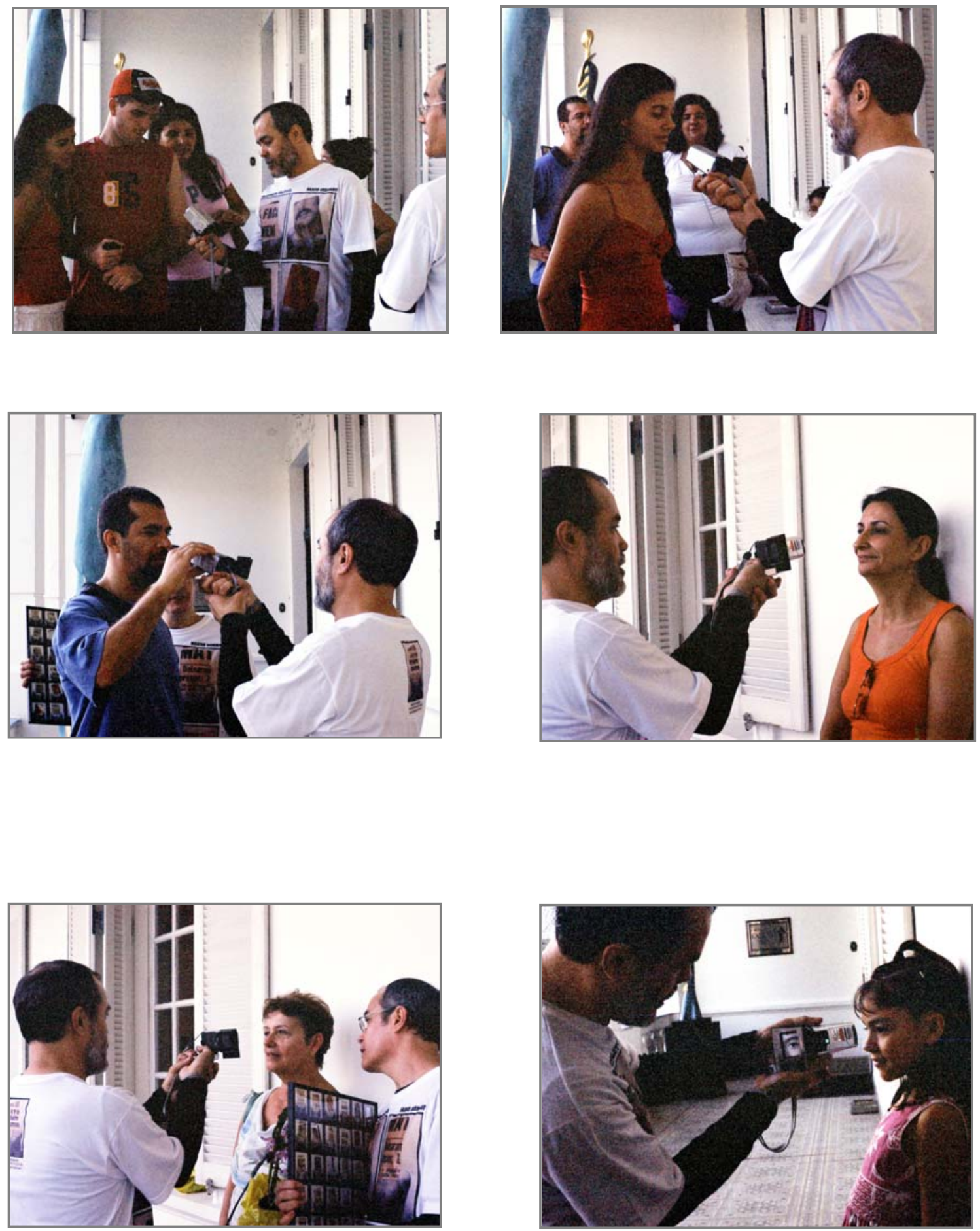

FIG. PPDSR-01 a 06 - Doe Seu Rosto/Give Me Your Face, 2001-2006 - Nardo Germano: Performance Participativa e Interativa.Pinacoteca Municipal Benedicto Calixto, Santos - SP, 2006. http://www.nardogermano.com/autoretratocoletivo/doeseurosto 


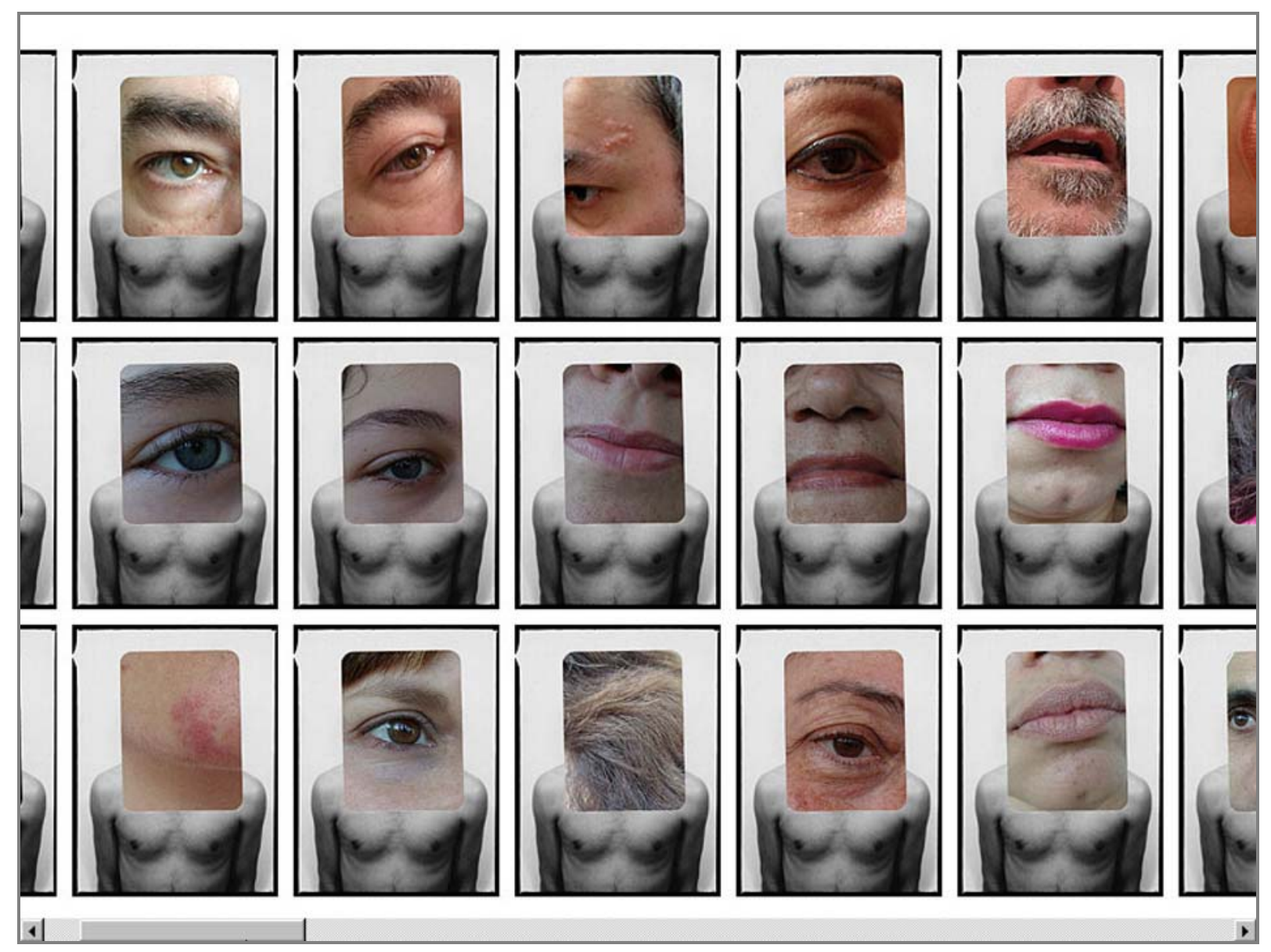

FIG. DSR-01 - Doe Seu Rosto/Give Me Your Face, 2001-2006 - Nardo Germano. http://www.nardogermano.com/autoretratocoletivo/doeseurosto 


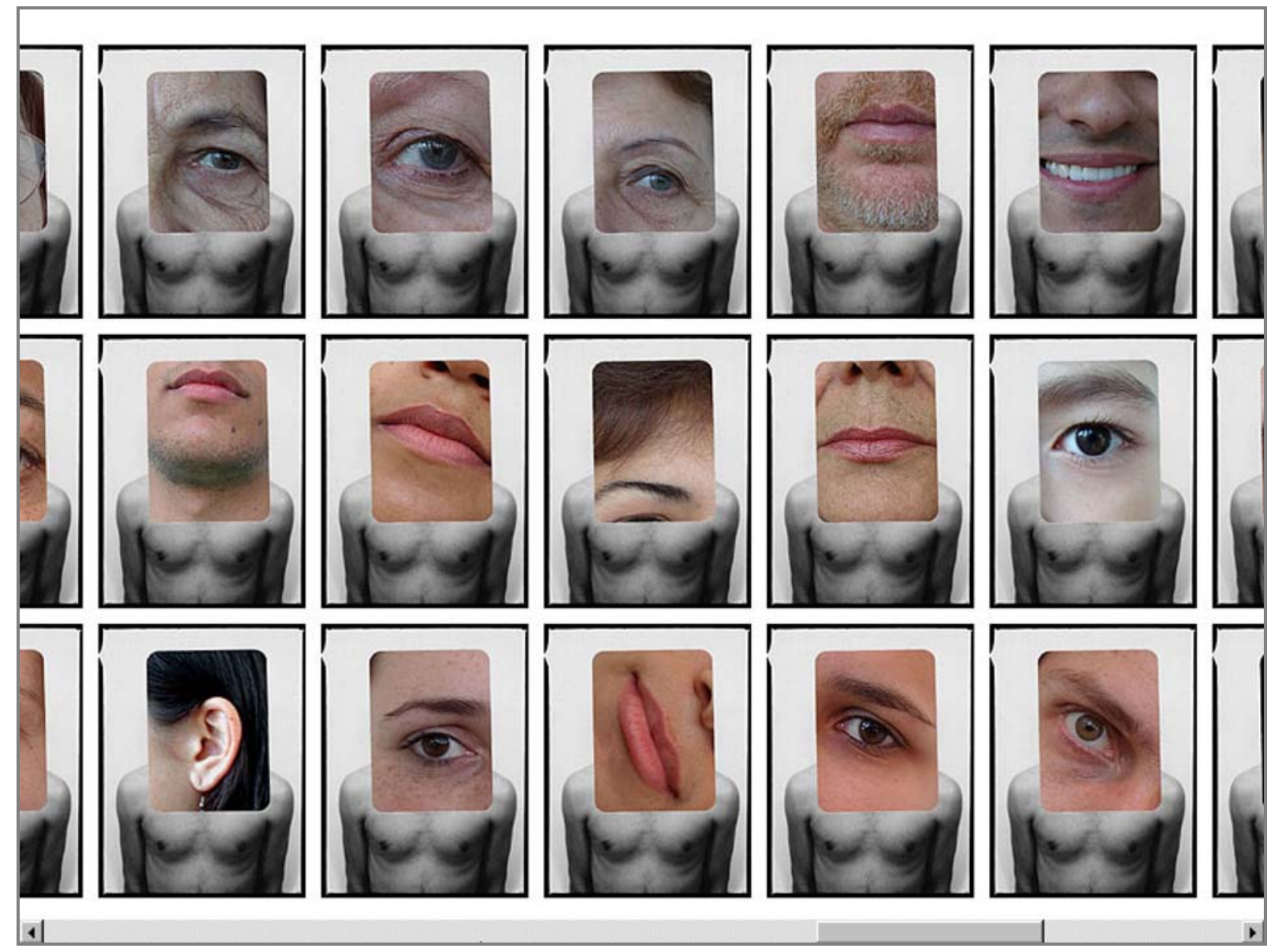

FIG. DSR-02 - Doe Seu Rosto/Give Me Your Face, 2001-2006 - Nardo Germano. http://www.nardogermano.com/autoretratocoletivo/doeseurosto 


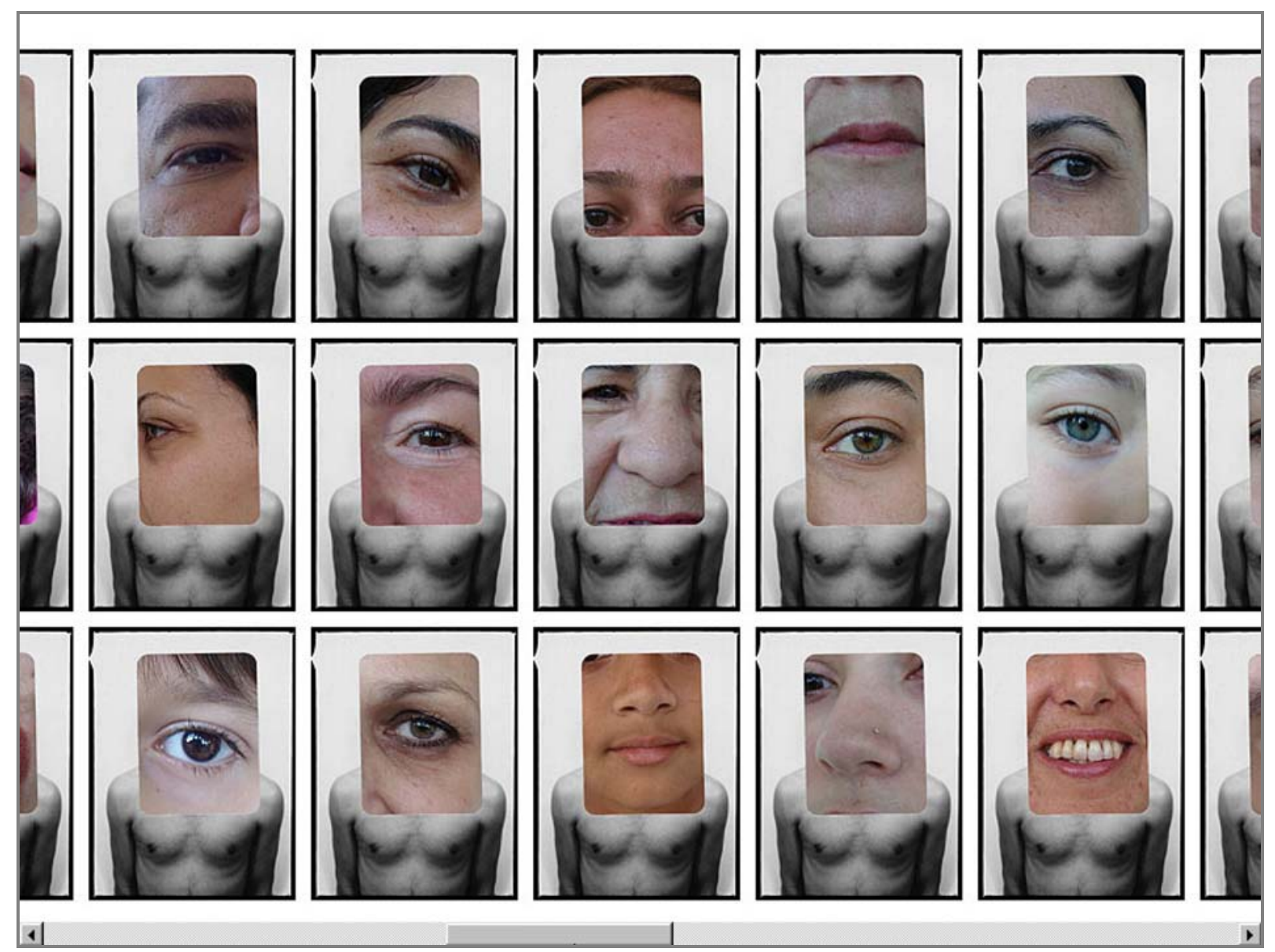

FIG. DSR-03 - Doe Seu Rosto/Give Me Your Face, 2001-2006 - Nardo Germano. http://www.nardogermano.com/autoretratocoletivo/doeseurosto 


\subsection{1. - ENTRE O PRESENCIAL E A TELEPRESENÇA}

Na proposição participativa (fig.PPDSR-01 a 06), o público realiza o registro fotográfico encaixando a parte escolhida do rosto no auto-retrato acéfalo fisicamente acoplado ao visor giratório da câmera digital.

Construído por meio de uma relação interpessoal, o resultado desse encontro é um auto-retrato mútuo, nascido de um diálogo ao vivo entre ambos - espectador e artista mediados pelo aparelho fotográfico digital -, que debatem e definem ângulo, enquadramento e outros aspectos relacionados à escolha do detalhe do rosto, motivações e história de vida, até a análise dos resultados e a contemplação estética do auto-retrato final.

Nessa proposição de participação, revela-se a característica "presencial" do evento. Instaura-se um corpo-a-corpo que propicia o compartilhamento do próprio ato fotográfico, no qual o artista e o participante assumem conjuntamente a realização do auto-retrato. Cria-se um clima de revelação e transparência entre participantes e performers: os diferentes critérios adotados por pessoas de mesmo núcleo familiar ou de relações afetivas tornam-se alvo de comentários entre os componentes do grupo, gerando críticas ou consenso diante da escolha individual manifestada. Para resguardar a autenticidade da obra, nos casos de conflito prevaleceu a decisão tomada pelo próprio participante, garantindo-lhe o direito ao exercício de sua própria identidade em debate.

Inaugurada na Pinacoteca Benedicto Calixto (Santos-SP), em 23 de julho de 2006, o contexto da obra é apresentado em três modalidades: 1 . exibição de um conjunto de imagens da série Sujeitos impressas em camisetas na mala que acompanha os performers; 2. exibição 
da obra Especulares \#7 que, por ser composta de espelhos nos recortes vazados dos autoretratos acéfalos, promove uma primeira experimentação ao refletir os detalhes dos rostos dos propensos participantes; e 3. exibição na própria câmera fotográfica digital, adaptada à proposta, um slide-show prévio da colagem digital a ser realizada, composto por detalhes de meu próprio rosto e de meus alter-egos Agnus Valente e Zilma Barros, aos quais se juntam as identidades que os participantes doaram de seus rostos para o Auto-Retrato Coletivo.

$\mathrm{Na}$ proposição de interatividade (fig.DSR-01 a 03), a característica "presença à distância" do meio promove um compartilhamento de identidades entre o artista e o interator numa base semiótica quando este envia um detalhe de seu auto-retrato para ser inserido no espaço vazado do auto-retrato acéfalo. Neste caso, o ato fotográfico em si não é compartilhado com o artista, posto que é realizado em espaços e tempos distintos. O encontro dessas individualidades que aspiram à coletividade se efetiva pela mediação da web, onde então se contemporizam na colagem digital exibida on-line.

As relações inerentes à interação realizada ocorrem numa espécie de opacidade quanto às motivações do interator na escolha metonímica que realiza. Diferentemente da experiência com as intervenções realizadas na Pinacoteca Benedicto Calixto, em que muitas motivações ficaram esclarecidas no momento da participação, as colagens realizadas on-line não trazem essas informações complementares.

Considerando-se a noção de obra-acontecimento das intervenções, advinda da própria aura dos eventos in loco enquanto "objet autographique unique"259 que é, optou-se pela composição final da obra com todas as colagens (obtidas tanto diretamente quanto on-line)

\footnotetext{
${ }^{259}$ GenetTe, Gérard. L'Oeuvre de l'Art: immanence et transcendence Paris, Éditions du Seuil, 1994. p.84. Segue tradução: enquanto "objeto autográfico único" (t.a.)
} 
exibidas conjuntamente, sem legendas, reforçando uma oposição ao discurso verbal das notícias e manchetes de jornal empregadas nas colagens de Sujeitos.

\subsection{2. - AUTO-RETRATO E AUTO-REFERÊNCIA}

No processo do próprio ato fotográfico, Doe Seu Rosto/Give Me Your Face estabelece um diálogo com a obra Auto-Objeto, que deu origem à série Auto-Retrato Coletivo. Naquela obra, como autor, ofereci meu rosto para obter, a partir da repetição de minha identidade e individualidade, o caráter coletivo almejado. Em Give me Your Face, é o público quem “doa seu rosto" - mais especificamente uma parte de seu rosto — para a obtenção de uma cabeça coletiva que se configura no efeito cumulativo das participações e interações.

Tanto na proposição de participação quanto na de interatividade, a questão identitária é subvertida. O caráter indicial da fotografia é aqui proposto como uma experiência nãoindiciária, na medida em que o efeito metonímico da proposição inviabiliza a conexão com a fotografia de documentos ou criminalística. Confrontados com uma proposição que não pede o estereótipo, mas uma auto-reflexão sobre identidade que tem a própria pessoa como foco, tanto os participantes como os interatores podem tomar deliberações que priorizem aspectos pessoais, resultantes de sua própria experiência de vida. A escolha feita pelo público quanto ao detalhe de seu rosto a ser doado para a obra escapa do contexto do registro oficial catalográfico de uma tipologia identitária. A proposta não determina critérios, mas transfere para o público a prerrogativa dos critérios identitários a serem adotados ou empregados. A pluralidade de motivações varia desde a busca de inclusão social ou a recuperação da autoestima perdida, à manifestação de uma subjetividade narcísica ou de uma mítica pessoal: 
desse modo, suplanta-se qualquer categorização oficial sustentada na padronização da identidade social.

Nessa mesma perspectiva, a obra privilegia a não-padronização do próprio registro fotográfico. A pós-produção para a obtenção da colagem digital deliberadamente dispensa filtros de correção de luz e cor. Não há um controle da origem e condições de luz das imagens enviadas pela web. Assim, o registro de cada detalhe de olho, boca, nariz, corresponde antes a um olhar, um sorrir, uma expressão, uma intenção, uma circunstância, uma história. Proponho uma transferência da noção de identidade embasada na estatística de compleições meramente físicas para a constituição de uma ânima que dá sentido à "adesão" do público à proposta da obra. Trata-se de uma identidade metonímica que procura resgatar, na ênfase da parte pelo todo, "pars pro toto", uma história identitária pessoal no cruzamento do autoretrato intimista com o coletivo, revertendo assim o processo de apagamento da identidade ${ }^{260}$ do indivíduo no corpo social.

Pela dupla proposição de abertura, a obra instaura uma síntese entre a Poética do Jogo e a Poética da $A c ̧ a ̃ o^{261}$, em que a performance do interator, enquanto participação mediada corporalmente, é registrada e se transfere em definitivo para o corpo da obra. Cabe ressaltar que mesmo na situação on-line, diante do computador, o interator também realiza uma participação mediada corporalmente, recordando que os níveis de abertura comportam os níveis anteriores. Nesse sentido, observa-se uma correspondência com a obra Especulares \#7 (cf. Cap.II) no que tange à predominância do espírito de $l u d u s^{262}$ na performance corporal, pelo reconhecimento e cumprimento das regras do jogo, aqui embasado no método dos limites

\footnotetext{
${ }^{260}$ CHIARELLI, Tadeu. "Identidade/não identidade - sobre a fotografia brasileira hoje". In: Arte Internacional Brasileira, São Paulo, Lemos-Editorial, 1999, p.132 e seguintes.

${ }^{261}$ TAvares, Monica. A Recepção no Contexto das Poéticas Interativas. S.Paulo, SP. Tese de Doutorado ECAUSP. 2000, pp.76-85 e pp.95-101

${ }^{262}$ CAILlois, Roger. Les Jeux et les Hommes: Le masque et la vertige. Paris, Gallimard, 1958, pp 55-57.
} 
inerente à identidade metonímica proposta. Para inserir uma parte do rosto no diminuto recorte vazado da imagem, o participante/interator realiza uma performance que se desenvolve numa conjunção dos princípios do jogo ${ }^{263}$ aqui estabelecida na constituição do binômio agôn/mimicry, na medida em que, nesse momento, o indivíduo necessita exercer suas habilidades físicas e motoras, relacionadas ao princípio agôn, para cumprir o impulso fundamental mimicry, enquanto imitação de si como outro ${ }^{264}$, colocando-se diante da objetiva e incorporando uma expressão que julga representá-lo, segundo a sua concepção de si mesmo.

Movido pelo impulso mimicry, o indivíduo experimenta uma problemática que transcende a mera aparência (que ocorre tanto nas situações em que se auto-retrata quanto ao ser fotografado por outro). Barthes a descreve primorosamente em A Câmara Clara:

"Ora, a partir do momento em que me sinto olhado pela objectiva, tudo muda: preparo-me para a pose, fabrico instantaneamente um outro corpo, metamorfoseio-me antecipadamente em imagem. Esta transformação é activa: sinto que a Fotografia cria o meu corpo ou o mortifica a seu bel-prazer $[\ldots]$.

Posando diante da objectiva (quero dizer, sabendo que estou a posar, mesmo fugidiamente), não arrisco tanto (pelo menos por agora). Sem dúvida é metaforicamente que extraio a minha existência de fotógrafo. Mas essa dependência, por muito imaginária que seja ( e do mais puro Imaginário), vivo-a na angústia de uma filiação incerta: uma imagem - a minha imagem - vai nascer; irei ser parido como um indivíduo antipático ou como um 'tipo fixe'? [...] Mas como aquilo que eu gostaria que fosse captado é uma textura moral fina, e não uma mímica, e como a Fotografia é pouco subtil, salvo em muito bons retratistas, eu não sei como agir do interior sobre o meu aspecto. [...] Presto-me ao jogo social, poso, sei isso muito bem, quero que também o saibam, mas esta mensagem suplementar não deve alterar em nada (no fundo, a quadratura do círculo) a essência preciosa da minha individualidade, aquilo que sou, para além da efígie."265

O impulso fundamental mimicry, presente no jogo do ato fotográfico, transita assim entre identidade e alteridade, tal como experimentei em 1987 na cabine Fotomática, na origem de todo o projeto Auto-Retrato Coletivo:

\footnotetext{
${ }^{263}$ CAILloIS, Roger. Les Jeux et les Hommes: Le masque et la vertige. Paris, Gallimard, 1958, pp 145-158

${ }^{264}$ CAILlois, Roger. Les Jeux et les Hommes: Le masque et la vertige. Paris, Gallimard, 1958, p 64

${ }^{265}$ BARTHES, Roland. A Câmara Clara. Lisboa-Portugal, Edições 70, Col. Arte e Comunicação, vol.12, 1981 (tradução: Manuela Torres),pp.25-27
} 
"Subjetividade posando. Jogo mútuo de aparências: a fisonomia informa sobre o Ser, atribuindo-lhe um caráter. Concentro-me. 'Faço-me' diante da objetiva. Embora consciente do espocar do flash - e o pressinta - , tal instante é um rompimento: o rompimento da minha concentração. O flash destrói a mímica. Em prol da objetividade. $" 266$

Nessas duas situações, ao ser fotografado por outro ou realizando um auto-retrato, o indivíduo está movido pelo impulso mimicry enquanto imitação de si mesmo como outro.

Contudo, essas duas experiências se passam num contexto em que é necessário exercer metaforicamente o papel de fotógrafo, ou como nomina Barthes - operator $^{267}$, para projetar a construção de si mesmo no momento do registro fotográfico. Auto-Objeto, por exemplo, é contituído por um conjunto de auto-retratos cegos, resultantes da antítese entre spectrum/operator.

Destaca-se um fator diferencial e relevante do contexto da fotografia digital trazido para a experiência do impulso mimicry vivenciado em Doe seu Rosto/Give me Your Face: não é mais metaforicamente que o participante e o interator exercem sua experiência de fotógrafos pois a instantaneidade do sistema supera a limitação do auto-retrato cego oferecido pelas câmeras convencionais. Os auto-retratos digitais, com os novos recursos de visualização, oferecem condições para a auto-referência no que concerne à expressão, ângulo e enquadramento. As webcams retornam ao indivíduo a sua imagem em tempo real no monitor do computador para ser registrada, permitindo-lhe uma visão de si, colocando-o mais conscientemente na sua ambivalência identidade/alteridade pela síntese entre

${ }^{266}$ GERMANO, Nardo. Identidade Coletiva em Auto-Objeto (1987) www.nardogermano.com 2004.

${ }^{267}$ BARTHES, Roland. A Câmara Clara. Lisboa-Portugal, Edições 70, Coleção Arte e Comunicação, vol.12, 1981 (tradução: Manuela Torres) pp..23-24: Barthes estabelece a distinção Operator/Spectrum/Spectator, respectivamente Fotógrafo/Fotografado/Espectador. 
spectrum/operator. Nessa nova condição, a ubiqüidade do sistema soluciona a dicotomia entre estar diante ou atrás da objetiva, aproximando-se da experiência de ubiqüidade especular.

Em Give me your Face/Doe seu Rosto, o efeito de luz-através preside o momento de captura dos auto-retratos, aspecto de fundamental importância, uma vez que a luz tem a capacidade de eliminar os fatores "de tempo e espaço da associação humana [...] criando a participação em profundidade"268. Assim, o caráter ucrônico e a ubiqüidade da experiência promovem um mergulho ontológico em que a imagem retornada no monitor projeta-se no olho do próprio auto-retratado: quase num looping, numa retroalimentação, pode-se promover a auto-consciência em profundidade, abstraindo os elementos sócio-históricos coercitivos e construtores da falsa consciência de identidade. Indiretamente, a recolocação desse elemento de individualidade em cena pode promover uma libertação da falsa-consciência e, assim, reinaugurar as condições para que o interator ou participante reflita sobre essas identidades para então se tornar apto a redimensionar sua consciência de si e sua consciência de classe.

Por sua característa enquanto "art autographique multiple"269, as colagens realizadas em Doe seu Rosto/Give me your Face se desdobram em diversos objetos. Num gesto final de abertura ao espectador, o artista oferece ao público que contribuiu com a obra um download das imagens, acompanhadas de uma metafórica declaração de inclusão nos termos "AutoRetrato Coletivo de Nardo Germano: Eu Faço Parte!”. O princípio de inclusão na frase é mais um elemento que busca fortalecer uma identidade autêntica através da noção de indivíduo que

\footnotetext{
${ }^{268}$ MCLuHAn, Marshall. Os Meios de Comunicação como Extensões do Homem (Understanding Media), S.Paulo, Ed.Cultrix, 5a ed., 1979, (tradução: Décio Pignatari) p.23

${ }^{269}$ GeneTte, Gérard. L'Oeuvre de l'Art: immanence et transcendence Paris, Éditions du Seuil, 1994. p.84. Segue tradução: "arte autográfica múltipla".
} 
faz parte de um todo, com sua singularidade respeitada em prol mesmo do coletivo multifacetado e poliédrico.

Além disso, há o momento de fruição que privilegia a contemplação da obra, com exibição in loco do slide-show, também disponível na web. Num jogo entre o individual de cada colagem e o coletivo do corpus conjuntamente constituído, os nossos auto-retratos encontram-se juntos em exibições tanto no meio digital, em monitor de vídeo, quanto no espaço físico em futuras instalações de parede, em saídas fotográficas. Nos dois casos, a obra se configura numa imagerie organizada em extensão, como um memorial onde cada autoretrato compõe com sua individualidade a noção de diversidade de Auto-Retrato Coletivo.

Diversidade humana capaz de, por si mesma, questionar estereótipos identitários e maniqueísmos ideológicos tão nocivos sobre o nosso modo de ser; Doe seu Rosto/Give me Your Face prescinde de discursos verbais, ancorando-se num discurso visual. A própria visão das imagens é uma paradoxal polifonia de silêncios reveladores e utópicos. 


\title{
CONCLUSÃo
}

\section{IDENTIDADES UTÓPICAS / IDENTIDADES ABERTAS}

\author{
"Um galo sozinho não tece uma manhã: \\ ele precisará sempre de outros galos. \\ De um que apanhe esse grito que ele \\ e o lance a outro; de um outro galo \\ que apanhe o grito que um galo antes \\ e o lance a outro; e de outros galos \\ que com muitos outros galos se cruzem \\ os fios de sol de seus gritos de galo, \\ para que a manhã, desde uma teia tênue, \\ se vá tecendo, entre todos os galos. "270
}

Tecendo a Manhã, João Cabral de Melo Neto

A série Auto-Retrato Coletivo em sua origem compunha-se de um conjunto de autoretratos sem negativo obtidos em cabine Fotomática e de colagens de auto-retratos acéfalos com recortes de notícias, fotos e manchetes de jornal. Discutindo a questão da construção da identidade social, a série expandiu-se para a constituição de auto-retratos híbridos entre o Indivíduo e o Coletivo, finalmente organizando-se artisticamente como repositório crítico de uma identidade coletiva.

Esta pesquisa tem como referência tanto as obras originais da série quanto as obras que a precedem. Do tema da identidade (individual e/ou coletiva) ao dialogismo, como uma metáfora produzida dentro do discurso do próprio artista enquanto autor que constrói os sentidos em curso, essas obras-referência contextualizam a pesquisa criativa atual - que propõe novas estratégias de abertura ao receptor - e são aqui apresentadas como Antecedentes e Paradigmas Internos da Criação. De um lado, considero como Antecedentes algumas obras que já prenunciam sinais e inquietações quanto aos meandros entre auto-retrato e identidade, como a série Nus Sem Cabeça (1981-1985), que inaugura o auto-retrato acéfalo na minha

\footnotetext{
${ }^{270}$ Melo Neto, João Cabral. Poesias Completas (1940-1965), R.Janeiro, José Olympio Ed., $3^{\text {a }}$ ed.,1979, p.19
} 
produção de ensaios fotográficos, e Projeção para Tungstênio e Fluorescentes de 1986, enquanto auto-retrato in absentia. De outro lado, um conjunto de obras constitui mais nitidamente o contexto da atual pesquisa, compondo o Paradigma Interno da Criação. Já no próprio processo de criação de Auto-Retrato em Natureza Morta, de 1985, encontram-se fotogramas (descartados da obra final) que tangenciam a problemática da identidade social em registros indiciários. Mas é nas obras inaugurais da série Auto-Retrato Coletivo, nos ensaios Auto-Objeto e Sujeitos, ambos de 1987, que a proposição do tema da identidade social toma corpo, explicitando-se. Auto-Objeto permanece como uma referência da expansão de minha identidade individual para uma dimensão coletiva através da repetição de auto-retratos em fotos de documento da Cabine Fotomática. Sujeitos, composto por colagens de auto-retratos acéfalos com recortes de jornal, é eleito como corpus imanente, a partir do qual as novas obras foram produzidas durante a pesquisa artística.

Ao debruçar-me no estudo crítico dessas obras, e circunscrevê-las em seu contexto temático, histórico e artístico, verifiquei na transição de Auto-Objeto para Sujeitos uma maior disponibilidade artística à participação do espectador. Reconheci a premência de elaboração de estratégias para atender à necessidade latente nos procedimentos poéticos da série e, assim, cumprir sua vocação dialógica. A partir da associação entre dialogismo e abertura da obra - e reconhecendo no Paradigma Interno da Criação uma abertura de primeiro grau -, a pesquisa criativa adotou sua hipótese de trabalho na perspectiva de um investimento nos graus de abertura da obra ao receptor, respectivamente em segundo e terceiro graus ${ }^{271}$, visando a participação e interatividade, expandindo-se, assim, à luz do conceito de Obra Aberta ${ }^{272}$.

\footnotetext{
${ }^{271}$ PLAZA, Julio. Arte e Interatividade: autor-obra-recepção, 2000 Acessado em 25/06/2003, [http://www.plural.com.br/jplaza/texto01.htm]

${ }^{272}$ ECO, Umberto. Obra Aberta, Coleção Debates, São Paulo, Editora Perspectiva. 1988 (trad. Giovanni Cutolo)
} 
A implementação de estratégias de abertura ao receptor se efetivou no intuito de alcançar um dialogismo diferenciado daquele que vinha se desenvolvendo nas obras anteriores da série. A proposição visava a contrapor novas qualidades dialógicas e polifônicas ao monologismo da construção ideológica de uma identidade coletiva embasada em estigmas sociais, além de redimensionar a polifonia orquestrada por minha presença autoral.

No transcorrer da pesquisa artística, o corpus da série Auto-Retrato Coletivo foi incrementado com a inserção de novas obras, às quais corresponde uma reiteração de minha poética pessoal que investiga o auto-retrato, deslocando-o de categorizações reducionistas e de construções de modelos identitários. No espírito de uma subjetividade formante que, de um lado, imprime na obra o seu ser social, ideológico, artístico, existencial e, de outro, se coloca em aberto à recepção, as obras foram criadas na sua dialética intrínseca de origem: entre o Indivíduo e o Coletivo.

A implementação das novas estratégias para a recepção de Auto-Retrato Coletivo inaugurou novas modalidades de abertura dialógica ${ }^{273}$ na série, propiciando aos espectadores uma participação mediada corporal e instantaneamente no contexto das obras em movimento ${ }^{274}$. Esse processo de abertura promoveu a conversão dos espectadores em participantes ou interatores, correspondendo à conversão de aisthesis em poiesis sublinhada por Jauss ${ }^{275}$, numa perspectiva crítica. As obras tornaram-se receptivas às predisposições e aos pontos de vista do público, incorporando-os não como comentários ou legendas extraobra, mas como signos (de identidade) que compõem o próprio objeto artístico na medida em

\footnotetext{
273 BAKHtin, Mikhail. La Poétique de Dostoievski, édition du Seuil, 1970, p.347

274 TAvares, Monica. A Recepção no Contexto das Poéticas Interativas. S.Paulo, SP. Tese de Doutorado ECAUSP. 2000, pp.93-101 .pp.74-101

${ }^{275}$ JAUSS, Hans Robert. Pour une esthétique de la réception. Paris, Gallimard, 1978, pp.123-157
} 
que introduzem e acrescentam a sua singular formatividade ${ }^{276}$ à singularidade do autorpropositor da obra. A inclusão do público, de sua poética e expressão, contribui para a expansão desse auto-retrato coletivo que, a partir de agora, é representado por um corpus construído em coletividade, comprovando a minha hipótese inicial de que o dialogismo e a polifonia, associados aos novos graus de abertura propostos ao espectador, repercutiriam profundamente na noção de identidade coletiva veiculada na obra.

A abertura ao espectador em segundo e terceiro graus realizou-se respectivamente com o concurso das poéticas do Jogo e da Ação. Nesse contexto, o método dos limites, o método permutatório e mesmo as Poéticas da Sugestão, do Estranhamento e do Distanciamento recorrentes no contexto da produção das obras que deram origem à série, são elementos para a elaboração de uma poiesis dos espectadores, numa perspectiva reflexionante, crítica.

Tais proposições de participação e interatividade pressupõem e/ou deflagram conseqüências políticas. Em se tratando de uma obra aberta ao espectador com temática de cunho social, espera-se que a contribuição não se realize somente no sentido espectador/obra, mas também obra/espectador.

Enquanto engendramento de uma Poética do $\mathrm{Jogo}^{277}$ nas estratégias de participação, estão previstas em meu campo de intencionalidades as implicações do jogo como fenômeno de cultura com função social ${ }^{278}$. Nas obras Auto-Retrato por Metro Quadrado, AutoRetr_Ato_Coletivo, Especulares \#7, Cabeça Defronte e na performance Corpo Coletivo, as estratégias planejadas e executadas solicitam uma mediação corporal do espectador para a sua

\footnotetext{
${ }^{276}$ PAREYSON, Luigi. Estética - Teoria da Formatividade.R.Janeiro, Ed.Vozes, 1993 (tradução: Ephraim Ferreira Alves)

277 Tavares, Monica. A Recepção no Contexto das Poéticas Interativas. S.Paulo, SP. Tese de Doutorado ECAUSP. 2000, pp.93-101 e.pp.76-85

${ }^{278}$ HuIzINGA, Johan. Homo Ludens - a study of the play element in culture. Boston, Beacon Press, $5^{\mathrm{a}}$ ed.,1966
} 
participação. Nos impulsos dialéticos do jogo entre $l u d u s$ e paidia $^{279}$, a dimensão política se constitui como exercícios tanto de organização social quanto de transgressão. Na Poética da Ação ${ }^{280}$, engendrada nas estratégias de interatividade, a extensão social intencionada equivaleria à possibilidade de transformação não apenas da obra, mas também do indivíduo no seio da sociedade, propondo a transposição da passividade de um hipotético internauta, enquanto ator social, para o indivíduo socialmente atuante, por meio desses exercícios de "ação": escolher entre ego ou alter-ego e distorcer um corpo coletivo virtual na obra AlterEgo; enviar seu ponto de vista para a "cabeça coletiva" de ANDROMAQUIA On-Line; ou realizar um auto-retrato metonímico adotado como forma extra-oficial de identidade, na obra Doe seu Rosto/Give me your Face.

Nesse sentido, Auto-Retrato Coletivo não se propõe apenas como uma obra participativa ou interativa que solicita a colaboração dos espectadores para existir enquanto tal, transformada pela presença plural que lhe confere dialogismo e polifonia. Propõe-se também, e sobretudo, como uma obra transformante, na medida em que, enfrentando as coerções do sistema e do processo de criação no corpo da obra, o indivíduo assume metaforicamente a posição de sujeito de sua própria identidade num entorno relacional de alteridades com as quais debate, discute, dialoga.

Nessa confluência de pluralidades, o redimensionamento de minha presença autoral configura-se enquanto um autor em coletividade ${ }^{281}$, entre o indivíduo e o coletivo. Um "autoretrato coletivo" não pode prescindir de identidades, o que seria uma contradição à própria

\footnotetext{
${ }^{279}$ Tavares, Monica. A Recepção no Contexto das Poéticas Interativas, S.Paulo, SP. Tese de Doutorado ECAUSP. 2000, p.77 e CAILLOIS, Roger. Les Jeux et les Hommes: Le masque et la vertige. Paris, Gallimard, 1958

${ }^{280}$ TAVAReS, Monica. A Recepção no Contexto das Poéticas Interativas, S.Paulo, SP. Tese de Doutorado ECAUSP. 2000, pp.95-101

${ }^{281}$ Weissberg, Jean-Louis. "Les Paradoxes de la Téléinformatique” In: Présences à Distance. [http://hypermedia.univ-paris8.fr/weissberg/presence.htm]
} 
proposta de polifonia e dialogismo que mobilizou todo o processo de abertura ao espectador aqui encetado. Há que se considerar, além disso, a predisposição e o compromisso deste auteur en collectif para empreender novas abordagens e proposições nascidas das contribuições do público. Nessa perspectiva, a abertura da obra aos espectadores justifica-se de forma autêntica e profunda em sua efetividade, uma vez que o artista desenvolveria novas etapas do projeto, agregando e validando a polifonia de alteridades como possibilidade de exercício coletivo de criação artística, consciência crítica e transformação.

Auto-Retrato Coletivo configura-se artisticamente no engendramento de Poéticas Abertas, Participativas e Interativas, sem valorações hierarquizantes. Instaura uma experiência problematizadora em sua discussão ideológica, no confronto ao monólogo opressor ou alienante. Nesse espírito, propõe o livre encontro de idéias e sentidos numa perspectiva dialética do ideológico e do utópico ${ }^{282}$, quando exerce a crítica negativa ideológica simultaneamente com uma prática positiva como decifração de impulsos utópicos, aqui encetada com as estratégias de abertura ao espectador. De um lado, orquestraram-se proposições de participação e intervenção urbana que estabeleceram campos de transgressão para recriar a arte como vida e dar vazão a manifestações utópicas ${ }^{283}$. De outro lado, orquestraram-se proposições de interatividade, estabelecendo um contexto no qual um projeto estético-político possa lançar-se, superando as limitações geopolíticas, para o debate das identidades em rede, que suplanta a esfera da identidade nacional e transfere a discussão da identidade coletiva para o âmbito supranacional da consciência de classe.

\footnotetext{
${ }^{282}$ JAMESON, Fredric. O Inconsciente Político - a narrativa como ato socialmente simbólico. São Paulo, Editora Ática, 1992, p304 (tradução: Valter Lellis Siqueira). Cf. Cap I, "Encaminhamento para novas aberturas dialógicas".

${ }^{283}$ FAVARETTO, Celso. A Invenção de Hélio Oiticica, São Paulo, EDUSP, 1992, p.121
} 
Cumpre-se assim a vocação de um projeto artístico reflexionante em contraponto a uma identidade coletiva determinante e oficial, construída sob as bases de um discurso monológico, fechado, estigmatizante. Prospectivamente em aberto, o atual corpus artístico da série configura um campo amplificado de vozes, uma polifonia de idéias e discursos dialogizados como signos de identidades plurais, mutantes, em constante movimento e transformação.

Em suma, o exercício simultâneo do ideológico e do utópico em curso na série AutoRetrato Coletivo reelabora continuamente seu repositório crítico de uma identidade coletiva que, em sinergia com os procedimentos de abertura da obra à recepção, se constitui simultaneamente como um repositório utópico de identidades abertas. 


\section{BibLIOGRAFIA}

ARISTÓteles, Poética. São Paulo, Nova Cultural, Col. Os Pensadores, 1987. (trad: Eudoro de Souza)

BAKHTIN, Mikhail. La Poétique de Dostoïevski, édition du Seuil, 1970 (Tradução do russo: Isabelle Rolitcheff)

BAKHTIn, Mikhail. Questões de Literatura e de Estética (A Teoria do Romance), São Paulo, Ed.Unesp, $4^{a}$ edição, 1998 (Tradução do russo: Aurora Fornoni Bernadini, José Pereira Júnior, Augusto Góes Júnior, Helena Spryndis Nazário, Homero Freitas de Andrade)

BAKHTIN, Mikhail. Marxismo e Filosofia da Linguagem São Paulo, Hucitec, 6 a edição, 1992 (Tradução: Michel Lahud e Yara Frateschi Vieira, colaboração de Lúcia Teixeira Wisnik e Carlos Henrique D. Chagas Cruz)

BAKHTIN, Mikhail. Écrits sur le Freudisme Lausanne, éditions L'âge d'homme, 1980 (trad: Guy Verret)

BARILli, Renato. Curso de Estética, Lisboa, editorial Estampa, 1992 (tradução: Isabel Teresa Santos)

BARTHES, Roland. A Câmara Clara. Lisboa-Portugal, Edições 70, Coleção Arte e Comunicação, vol.12, 1981 (tradução: Manuela Torres)

BARTHES, Roland. La Chambre Claire: note sur la photographie. Cahiers du Cinéma, Éditions de l'Étoile, Gallimard, Le Seuil, 1980

BAUDRILlARD, Jean. Simulacros e Simulação. Lisboa, ed. Relógio d’Água, 1991 (trad. Maria João da Costa Pereira)

Benjamin, Walter. Magia e Técnica, Arte e Política. São Paulo, Ed. Brasiliense, Coleção Obras Escolhidas, vol. 1, 3. ${ }^{a}$ edição, 1987 (tradução: Sérgio Paulo Rouanet)

Bense, Max. Pequena Estética. São Paulo, Ed. Perspectiva, 2. ${ }^{\text {a }}$ ed., 1975 (tradução: Haroldo de Campos et alii)

BRETT, Guy. Brasil Experimental - Arte/Vida: proposições e paradoxos. Rio de Janeiro, Contra Capa Livraria, Coleção N-Imagem., 2005 (tradução: Renato Rezende)

CAmpos, Augusto e Haroldo, Pignatari, Décio. Teoria da Poesia Concreta. (textos críticos e manifestos 1950-1960) São Paulo, Livraria Duas Cidades, 1975

CAMPos, A. e H., PignATARI,Décio. Mallarmé. S.Paulo, Ed.Perspectiva, 3. a edição, 1991

CAMPOS, Haroldo. Metalinguagem: ensaios de teoria e crítica literária.Petrópolis,RJ,Vozes, 1970

. (org.). Ideograma: Lógica, Poesia, Linguagem. São Paulo, EDUSP, 3. a edição, 1984 (tradução: Heloysa de Lima Dantas).

. Sobre Finismundo: A Última Viagem, RJ, Sette Letras, 1996

. A Arte no Horizonte do Provável, SP, Perspectiva, 4a edição, 1977

CAILlOIS, Roger. Les Jeux et les Hommes: Le masque et le vertige. Paris, Gallimard, 1958 
ChiARELli, Tadeu. Arte Internacional Brasileira. São Paulo, Lemos-Editorial, 1999

O Auto-Retrato na (da) Arte Contemporânea - catálogo da exposição

"Deslocamentos do EU - O auto-retrato Digital e Pré-digital na Arte Brasileira (1976-2001). Itaú Cultural - Campinas, SP, 2001.

exposição) 1997

. Identidade/não identidade - sobre a fotografia brasileira hoje. (catálogo da

. "A Fotomontagem como Introdução à Arte Moderna': visões modernistas sobre a fotografia e o surrealismo. São Paulo, Revista ARS, ECA/USP, ano 1, no 1, 2003

Chklovski, V. "A Arte como Procedimento" in: Toledo, Dionisio de Oliveira (org.). Teoria da Literatura: Formalistas Russos. Porto Alegre, ed. Globo, $1^{\text {a }}$ ed. 1973

ClARK, Lygia. Lygia Clark, Rio de Janeiro, edição Funarte, 1980

Clark, Lygia. Da obra ao acontecimento - Somos o Molde. A você cabe o sopro. (catálogo da exposição) França/São Paulo - Musée des Beaux Arts e Pinacoteca do Estado de São Paulo, 2005/2006

Costa, Helouise, RodrIgUES, Renato. A Fotografia Moderna no Brasil. Funarte IPHAN - Ed UFRJ $-\mathrm{RJ}, 1995$.

. A Fotografia Moderna no Brasil. SP, Cosac Naify, 2004, $2^{\mathrm{a}}$ ed

COUCHOT, Edmond. A Tecnologia na Arte: da fotografia à realidade virtual. Porto Alegre, UFRGS editora, Coleção Interfaces, 2003 (tradução Sandra Rey)

. "Da Representação à Simulação: Evolução das Técnicas e das Artes da Figuração". In: PARENTE, André (org.) Imagem-Máquina: A Era das Tecnologias do Virtual, Rio de Janeiro, Editora 34, 1993

. "Sujet, Objet, Image". In: Leonardo éléctronique (Cahiers Internationaux de Sociologie, vol. LXXXII, 1987, pp.85-97) 2001

Domingues, Diana (org.) A Arte no Século XXI: a Humanização das Tecnologias, SP, Editora UNESP, 1997

DuCHAMP, Marcel. "O Ato Criador”, in A Nova Arte, org. Gregory Battcock. São Paulo, SP, Ed. Perspectiva, 2.ed., 1986

ECO, Umberto. Obra Aberta, Coleção Debates, São Paulo, Editora Perspectiva. 1988 (tradução de Giovanni Cutolo).

ECO, Umberto. As Formas do Conteúdo. São Paulo, Perspectiva/Edusp, 1974 (tradução: Pérola de Carvalho)

FABRIS, Annateresa. "A Fotografia e a Reprodutibilidade da Obra de Arte”. Arte em São Paulo, (12): s.p., 1982

. Identidades Virtuais. Belo Horizonte, Editora UFMG, 2004

Favaretto, Celso Fernando. A Invenção de Hélio Oiticica, Coleção Texto \& Arte nr. 6, São Paulo, Editora da Universidade de São Paulo - EDUSP, 1992. 
FAVILLA, André. O signo híbrido: breves impressões em relação à síntese entre a informação fotográfica e a digital, s/d. acessado em 25/06/2003, [http://wawrwt.iar.unicamp.br/].

FERrARA, Lucrécia D’Aléssio. A Estratégia dos Signos. São Paulo, Perspectiva,1981,

FLUCHETTI, R.. Vampirismo. Rio de Janeiro, Ebal, 1990

Flusser,Vilém. Filosofia da Caixa Preta. São Paulo, Hucitec, 1985

FOREST, Fred. Pour un Art Actuel - L'art à l'heure d'Internet. Paris, L'Harmattan, 1998

GenetTE, Gérard. L'Oeuvre de l'Art. Paris, Éditions du Seuil, 1994

Goodman, Nelson. Los Lenguajes del Arte: aproximación a la teoria de los símbolos, Barcelona, ed. Seix Barral, S.A., 1976 (trad.: Jem Cabanes)

HuIZINGA, Johan. Homo Ludens - a study of the play element in culture. Boston, Beacon Press, 5a ed.,1966

ISER, Wolfgang. “A Interação do Texto com o Leitor" in: LIMA, Luiz Costa (org.). A Literatura e o Leitor R.Janeiro, Paz e Terra 1979

JAKOBSON, Roman. Lingüistica e Comunicação. São Paulo, Ed. Cultrix, 13 a edição tradução: Izidoro Blikstein e José Paulo Paes, 1988 Poética em Ação. S.Paulo, Ed. Perspectiva/edusp, 1990

JAMESON, Fredric. O Inconsciente Político - a narrativa como ato socialmente simbólico. São Paulo, Editora Ática, 1992 (tradução: Valter Lellis Siqueira).

JAUSS, Hans Robert. Pour une esthétique de la réception. Paris, Gallimard, 1978

. "O Prazer Estético e as Experiências Fundamentais da Poiesis, Aisthesis e Katharsis” in: Lima, Luiz Costa (org.). A Literatura e o Leitor R.Janeiro, Paz e Terra 1979

KANT, Emmanuel. Critique de la Faculté de Juger. Paris - J. Vrin, 1984

KNELLER, George F. Arte e Ciência da Criatividade (C1965 S. Paulo, SP, Ed. Ibrasa, 1973

KraUSS, Rosalind. Lo Fotografico - Por una Teoria de los Desplazamientos. Ed.Gustavo Gili S.A. 2002

LANDOW, George P. The Definition of Hypertext and Its History as a Concept. http://www.cyberartsweb.org/cpace/ht/jhup/history.html

LaUrentiz, Paulo. A Holarquia do Pensamento Artístico, Campinas, S.Paulo, Ed. UNICAMP, 1991.

LAURENTIZ, Sílvia. (2004). "Questões da Imagem" In: VALENTE, Agnus (org.). HIBRIDA Revista Eletrônica. São Paulo, Brasil, maio/2005, acessado em 22/07/2005, [http://www.agnusvalente.com/hibrida]

LÉVY, Pierre. A Inteligência Coletiva: por uma antropologia do ciberespaço, São Paulo-SP, Ed. Loyola, $4^{\mathrm{a}}$ edição 2003 (tradução: Luiz Paulo Rouanet)

LÉVY, Pierre. O que é o Virtual? São Paulo-SP, Ed. 34, Coleção TRANS, 1996 (trad. Paulo Neves) 
LÉVY, Pierre. A Máquina Universo: criação, cognição e cultura informática, Porto Alegre, Ed. ARTMED, 1998.

LÉVY, Pierre. Cibercultura, S.Paulo-SP, Ed. 34, Coleção TRANS, 1999 (trad: Carlos Irineu da Costa) LEÃO, Lúcia (org). Interlab : Labirintos do Pensamento Contemporâneo, S.Paulo, Iluminuras, 2002.

LIMA, Luiz Costa (org.). A Literatura e o Leitor Rio de Janeiro, Paz e Terra 1979

Machado, Arlindo. A Ilusão Especular: introdução à fotografia, São Paulo, Ed. Brasiliense, 1984. / $2^{\text {a }}$ edição1993/1996. . Máquina e Imaginário: o desafio das poéticas tecnológicas, São Paulo, EDUSP, $1^{\text {a }}$ . "Repensando Flusser e as Imagens Técnicas" (1997) In: LEÃO, Lúcia (org). Interlab : Labirintos do Pensamento Contemporâneo, S.Paulo, Iluminuras, 2002

MALlaRmÉ, Sthephane. Un Coup des Dés jamais n'abolira le Hasard (Separata do livro Mallarmé, de Augusto e Haroldo de Campos e Décio Pignatari - S. Paulo, Ed. Perspectiva, Col.Signos, 3. edição, 1991)

Melo Neto, João Cabral. Poesias Completas (1940-1965), RJ, José Olympio Editora, $3^{\text {a }}$ ed., 1979

MCLUHAN, Marshall. Understanding Media: Os Meios de Comunicação como Extensões do Homem. S.Paulo, Ed. Cultrix, 1969 (tradução: Décio Pignatari)

Milliet, Maria Alice. Lygia Clark: Obra-Trajeto, Col. Texto \& Arte nr 8, São Paulo, EDUSP, 1992

Moles,Abraham A. A Criação Científica.S.Paulo,Perspectiva1981 (trad:Gita K.Guinsburg)

MORAES, Angélica de (Org.). Regina Silveira: Cartografias da Sombra. S.Paulo, EDUSP, 1995.

NUNES, Benedito. Introdução à Filosofia da Arte. São Paulo, Ática 2.a edição 1989

OiticiCA, Hélio. Aspiro ao Grande Labirinto, Rio de Janeiro, Editora Rocco Ltda., 1986.

OITICICA, Hélio. BLOCO - EXPERIÊNCIAS in COSMOCOCA, SP, Galeria Arte São Paulo, 1994.

PAREYSON, Luigi. Estética - Teoria da Formatividade. Rio de Janeiro, Petrópolis, ed. Vozes, 1993. (trad. Ephraim Ferreira Alves)

PAREYSON, Luigi. Os Problemas da Estética. S. Paulo, Martins Fontes, 1997. (trad: Maria Helena Nery Garcez)

PeIRCE, Charles Sanders. Semiótica, Col Estudo, São Paulo, Perspectiva.1977 (trad. José Teixeira Coelho Neto).

. Escritos Coligidos, Coleção Os Pensadores, São Paulo, Ed. Abril Cultural, $3^{\mathrm{a}}$. edição 1983 (trad. Armando Mora d'Oliveira e Sérgio Pomerangblum).

PeSSOA, Fernando. Obra Poética, RJ, Editora Nova Aguilar SA, $9^{a}$ edição, $4^{\mathrm{a}}$ reimpressão, 1986

PIgNATARI, Décio. Informação Linguagem Comunicação. São Paulo, SP, Ed. Cultrix, 1.ed., 1980

. Semiótica \& Literatura (Icônico e Verbal, Oriente e Ocidente). São Paulo, Ed.

Cortez \& Moraes, 2. ${ }^{a}$ edição, 1979 
PlaZA, Julio. Tradução Intersemiótica. São Paulo, Perspectiva, coleção Debates, 1987

. A Imagem Digital - Crise dos Sistemas de Representação. São Paulo, SP, tese de LivreDocência, ECA, USP, 1991

Processo Criativo: Metodologias. Apostila do curso homônimo, IA Unicamp, 1992-9

Arte e interatividade: autor-obra-recepção, 2000. Acessado em 25/06/2003,

[http://www.plural.com.br/jplaza/texto01.htm].

Plaza, Julio \& Tavares, Monica. Processos Criativos com os Meios Eletrônicos: Poéticas Digitais. São Paulo, SP, editora HUCITEC, 1998

POE, Edgar Allan. "The Philosophy of Composition”, from Criticism. in STERN, P. Van Doren. The Portable Poe. The Viking Portable Library, Penguin Books, 1986

POPPER, Frank. Art, Action et Participation: l'artiste et la créativité aujourd'hui. Paris, éditions Klincsteck, 1980 . Art of the Electronic Age. Thames and Hudson Ltd, 1993

PRADO, Gilbertto. "Dispositivos Interativos: Imagens em Redes Telemáticas" (1997). In: VALENTE, Agnus (Org.). HIBRIDA Revista Eletrônica, São Paulo, Brasil, maio/2005. [ www.agnusvalente.com/hibrida ] acessado em 05/07/2005.

. As redes telemáticas: utilizações artísticas, acessado em 25/06/2003 [http://wawrwt.iar.unicamp.br/gilbertto/index.html].

Experimentações artísticas em redes telemáticas e web, acessado em 25/06/2003. [http://wawrwt.iar.unicamp.br/gilbertto/index.html].

SANTAELlA, Lúcia e NÖTH, Winfried. Imagem : cognição, semiótica, mídia SPaulo, Iluminuras, 2a ed, 1999

SERRA, Antonio A. O Desvio Nosso de Cada Dia: a representação do cotidiano num jornal popular. Rio de Janeiro, Ed. Achiamé, 1980

SonTAG, Susan. Ensaios sobre a Fotografia. R. Janeiro, Ed. Arbor, 2. ${ }^{a}$ edição, 1983 (tradução: Joaquim Paiva)

Diante da Dor dos Outros. São Paulo, Companhia das Letras, 2003 (trad: Rubens Figueiredo)

TAVAres, Monica. A Recepção no Contexto das Poéticas Interativas. S.Paulo, SP. Dissertação de Doutorado ECA-USP. 2000

“A Leitura da Imagem Interativa” in: INTERCOM, Campo Grande, MS, 2001

"Aspectos estruturais e ontogênicos da Interatividade" in: Motta, Luiz Gonzaga, Weber, Maria Helena. França, Vera. Paiva, Raquel. (orgs.) Anul da Compós, 2001

. "A Especificidade da Imagem Interativa" in: Capisani, Dulcimira (org.)

Transformação e Realidade: mundos convergentes e divergentes, PROPP/CEAD/UFMS,

Campo Grande, MS, 2001 
"Fundamentos Estéticos da Arte Aberta à Recepção" in: Revista ARS, ECA/USP, ano I, número 2, 2003

. "O Pacto de Leitura das Poéticas Interativas" in: Anual da Compós, 2004

Valente, Agnus. Parabola-Imago: Transmutações Criativas entre o Verbal e o Visual. S.Paulo, SP. Dissertação de Mestrado ECA-USP. 2002

\& GERMANO, Nardo. Útero $\therefore$ Cosmos [http://www.agnusvalente.com/utero]

WeISSBERG, Jean-Louis. Auteur, Nomination Individuelle et Coopération Productive [1].

[www.info.unicaen.fr/bnum/jelec/solaris/d07/7weissberg.html]

.Présences à Distance. [http://hypermedia.univ-paris8.fr/weissberg/presence]

. "Simuler-Interagir-S'Hibrider = Le Sujet Rentre sur Scene". In: Modernes et Après? "Les Immatériaux". Paris. Editions Autrement. 1985 
ANEXOS 


\begin{abstract}
Anexo 1
Identidade Coletiva em Auto-objeto

" Ver-se a si mesmo (sem ser num espelho), à escala da história, é um acto recente.

(...) É curioso que não se tenha pensado na 'perturbação' (de civilização) que este acto novo traz. (...) Porque a Fotografia é o aparecimento de eu próprio como outro, uma dissociação artificiosa da consciência de identidade. "
\end{abstract}

( Roland Barthes, in 'A Câmara Clara')

1 .

Em busca de minha Identidade Fotográfica, abro mão da própria

atuação como fotógrafo, em prol de um auto-retrato "objetivo".

Submeto-me a um processo automático, instrumento capaz de

identificar-me dentro de um padrão pré-estabelecido de

objetividade.

Realizo o auto-retrato enquanto objeto da fotografia, associando

minha imagem ao processo de identificação dos seres como

Indivíduos Sociais.

$$
2 \text {. }
$$

Subjetividade posando. Jogo mútuo de aparências: a fisionomia

informa sobre o Ser, atribuindo-lhe um caráter.

Concentro-me. ''Faço-me'' diante da objetiva.

Embora consciente do espocar do flash - e o pressinta

-, tal instante

é um rompimento: o rompimento da minha concentração.

O flash destrói a mímica. Em prol da objetividade.

A obediência é um requisito para o ser que posa. A princípio

preciso seguir regras de comportamento diante da

câmera.

Desobedecer seria uma manifestação de contestação.

Fechado,

dentro da Fotomática, eu devo obedecer.

Mas tenho direito à desobediência. 


\section{3.}

O processo de massificação social, deflagrando-se através do

mecanismo fotográfico, aponta para uma atuação

ambivalente da

Fotografia, ora a serviço do Poder, ora como

instrumento de

conscientização da realidade opressora.

objeto do Poder, a Fotografia pode ser um instrumento de

eliminação da individualidade. A possível luta do Indivíduo

contra esse poder de generalização consiste na recusa de ser um objeto.

Ou, paradoxalmente, em subverter esse universo de significados

através de uma submissão voluntária e consciente,

para denunciar

os códigos de massificação.

4 .

Num dado momento, submeto meu rosto: objeto fotográfico.

Outros seres, através de mim, encontram expressão. Sua redundância multiplica-me.

E me transforma em todos: Identidade Coletiva.

Auto-Retrato Coletivo.

Nardo Germano, novembro de 1987. 


\section{Anexo 2}

Sujeitos: o deslocamento para a Dignidade

Nas fotos de "Sujeitos", a idéia de autoretrato se amplia

para uma solidariedade coletiva. Ao me

fotografar, ofereço

minha identidade como bandeira.

Retratado pela Fotomática, um elo social se estabelece entre mim

e minha imagem. Uma classe social inteira também foi retratada

quando o meu rosto recebeu a luz objetiva do flash.

Recortar o meu rosto e oferecer o espaço vago foi o gesto fotográfico dessa identificação.

De manchetes de jornais populares, alguns textos e imagens tornaram-se matériaprima

para uma colagem que pudesse representar essa identidade social e, sobretudo, uma forma de solidariedade ao seu drama.

Imagens duras e textos brutos foram utilizados nessa composição.

o sensacionalismo original, retirado de seu contexto 'jornalístico',

deslocado para o campo do auto-retrato,

torna-se,

entretanto,

um princípio de reflexão sobre a Dignidade Humana.

Nardo Germano, fevereiro de 1988. 


\section{ANEXO 3}
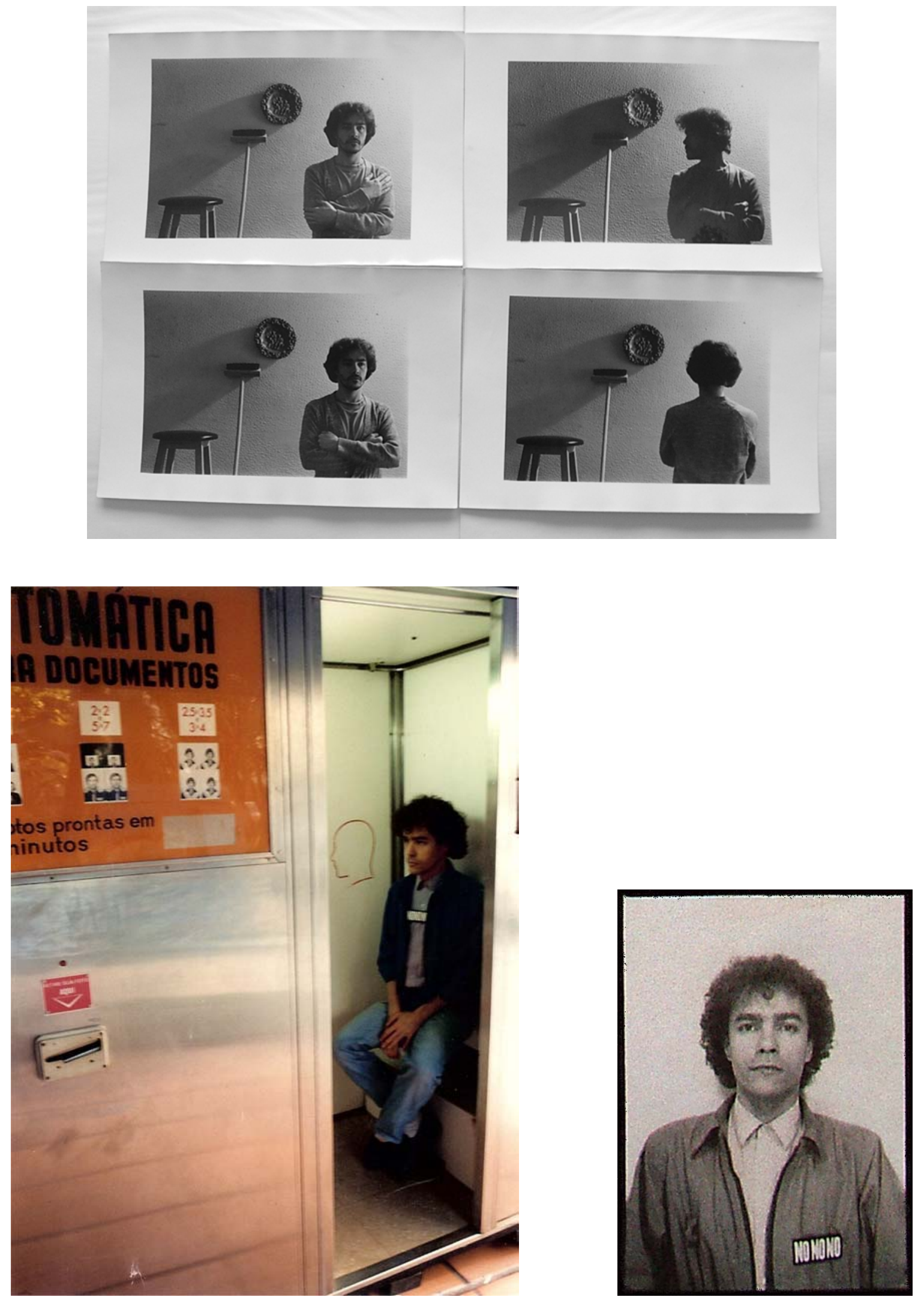

Fotos do processo de criação de Auto-Retrato em Natureza Morta (1985), descartadas na obra final, que conduziram ao Auto-Objeto, $1^{0}$ ensaio de Auto-Retrato Coletivo. 


\section{ANEXO 4}
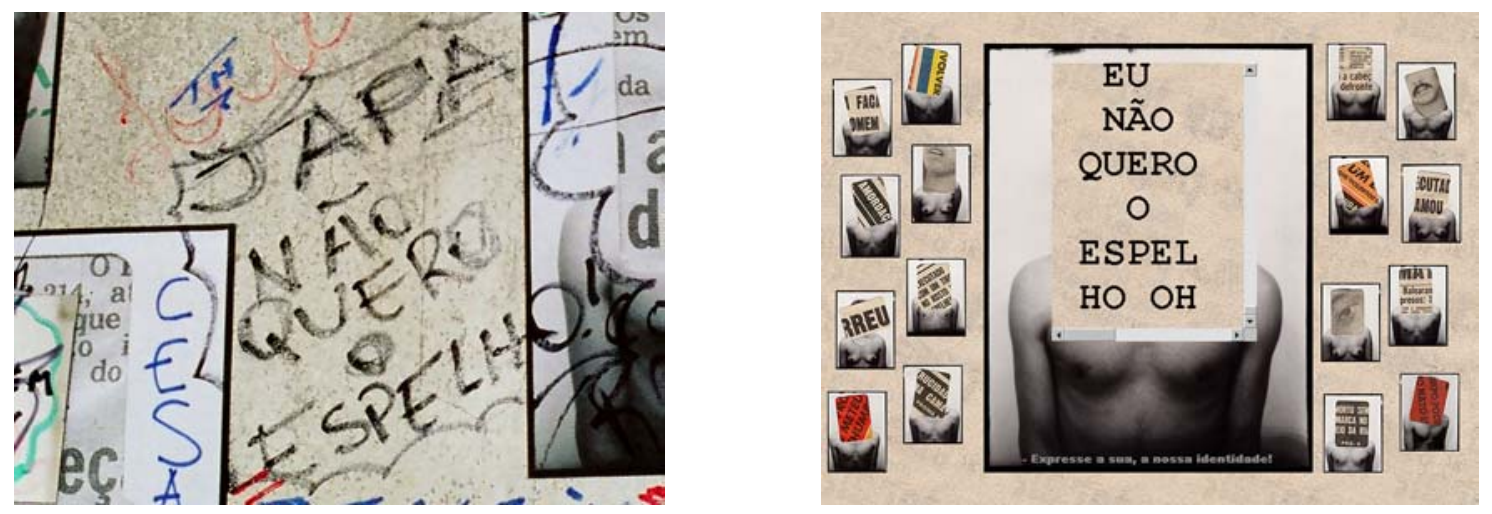

Inscrição de participante em Cabeça Defronte, que inspirou a primeira proposição de ANDROMAQUIA On-Line.

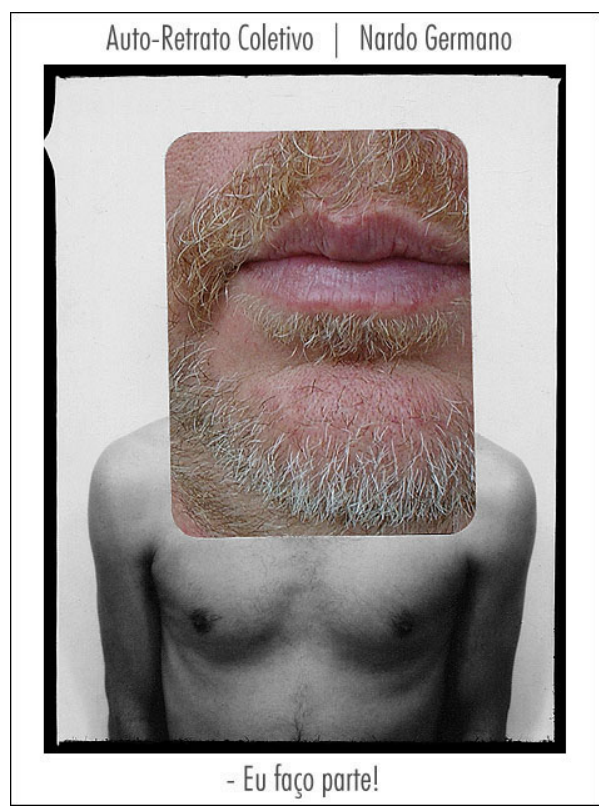

Imagem para download em Doe seu Rosto/Give me your Face, 2001-2006. 